\title{
Cretaceous and Cenozoic dinoflagellate cysts and other palynomorphs from the western and eastern margins of the Labrador-Baffin Seaway
}

Robert A. Fensome, Henrik Nøhr-Hansen \& Graham L.Williams 


\section{Geological Survey of Denmark and Greenland Bulletin 36}

\section{Keywords}

Biostratigraphy, Cretaceous, Cenozoic, dinocysts, systematics, Baffin Margin, Labrador Margin, Mesozoic, offshore West Greenland

\section{Cover illustration}

Selected palynomorphs from the subsurface of the Labrador-Baffin Seaway; for details, see Plates 1, 3, 4, 6, 7, 12, $15,17,18$.

Top left to bottom right: Dinoflagellates - Chiropteridium gilbertii sp. nov., Chatangiella tripartite, Cleistosphaeridium palmatum sp. nov., Diphyes brevispinum, Ginginodinium? flexidentatum sp. nov., Adnatosphaeridium vittatum, Piladinium columna, Thalassiphora pelagica, Eocladopyxis peniculata; Miospores - Aquilapollenites quadrilobus, Cicatricososporites eocenicus, Baculatisporites crenulatus sp. nov.

\section{Frontispiece: facing page}

The Canadian icebreaker Amundsen off Beechey Island in the Canadian Arctic in the autumn of 2013. Geological research in the Arctic is entirely dependent on such professional logistic support, whether by sea or air. Photo: Kate Jarrett (GSC).

Chief editor of this series: Adam A. Garde

Scientific editor of this volume: Jon R. Ineson

Editorial secretary: Jane Holst

Referees: Martin Pearce (UK) and James B. Riding (UK)

Illustrators: Jette Halskov (GEUS) and Bill MacMillan (GSCA)

Digital photographic work: Benny M. Schark

Graphic production: Annabeth Andersen

Printers: Rosendahls · Schultz Grafisk a/s, Albertslund, Denmark

Manuscript received: 21 January 2015

Final version approved: 17 March 2016

Printed: 19 December 2016

ISSN (print) 1604-8156

ISSN (online) 1904-4666

ISBN (print) 978-87-7871-443-5

ISBN (online) 978-87-7871-444-2

\section{Citation of the name of this series}

It is recommended that the name of this series is cited in full, viz. Geological Survey of Denmark and Greenland Bulletin.

If abbreviation of this volume is necessary, the following form is suggested: Geol. Surv. Den. Green. Bulletin 36, 143 pp.

\section{Available from}

Geological Survey of Denmark and Greenland (GEUS)

Øster Voldgade 10, DK-1350 Copenhagen K, Denmark

Phone: +45 381420 00, fax: +45 381420 50, e-mail: geus@geus.dk

or at www.geus.dk/publications/bull

(C) De Nationale Geologiske Undersøgelser for Danmark og Grønland (GEUS), 2016

For the full text of the GEUS copyright clause, please refer to www.geus.dk/publications/bull 


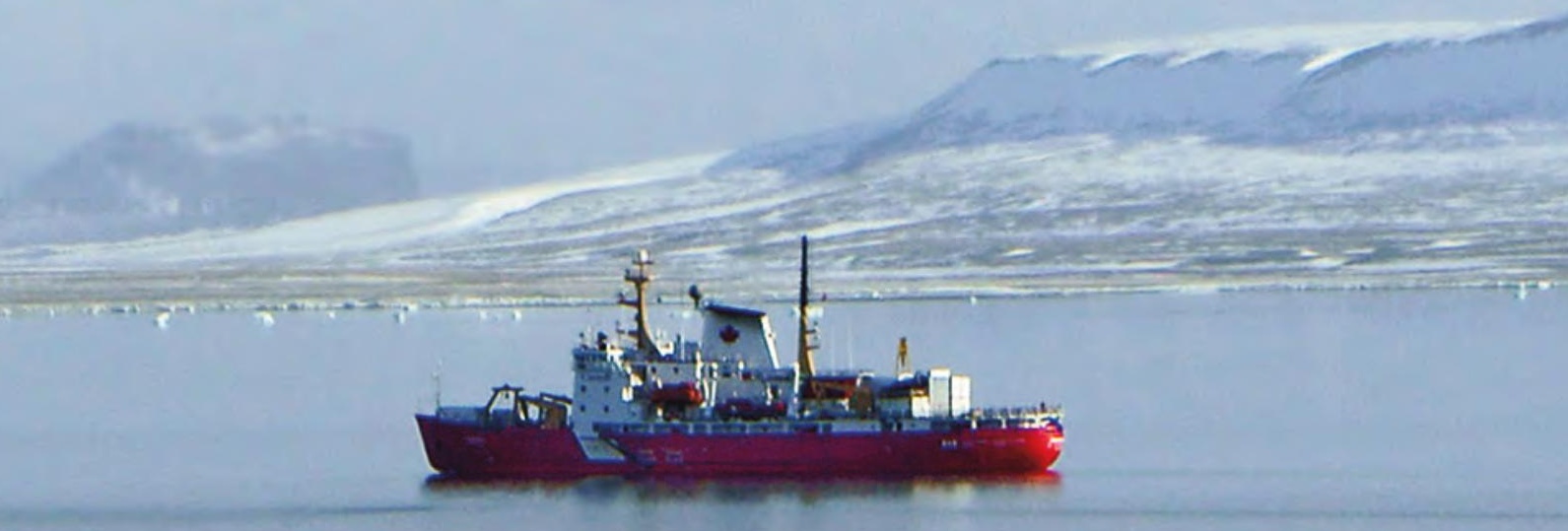

\section{Iक}
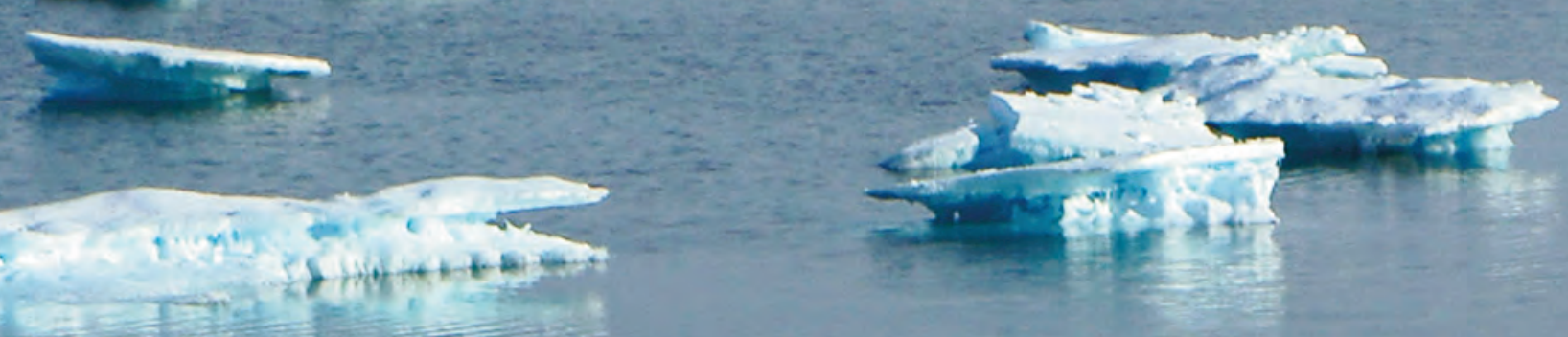

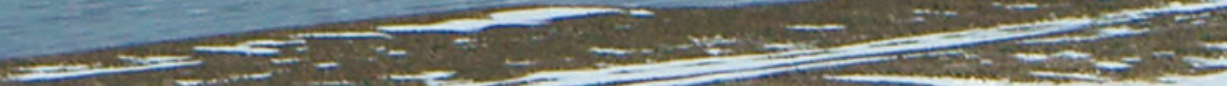

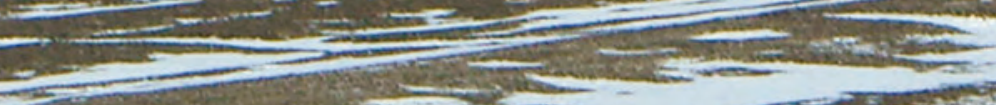

20

Ex-1.

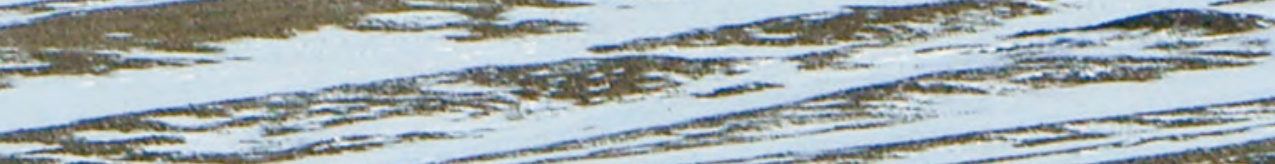

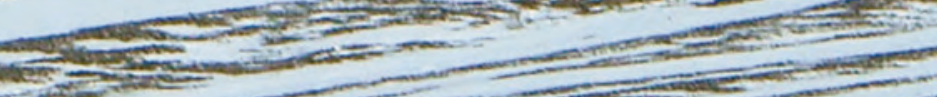

C. 1 -

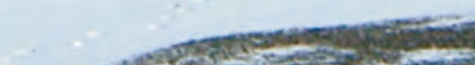

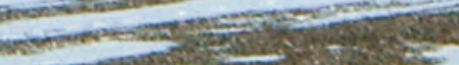
STras ene-

$\rightarrow$ antistist

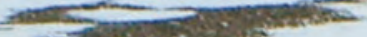

$=-$

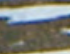

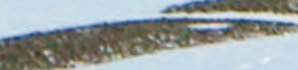

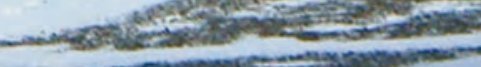
10.7. and

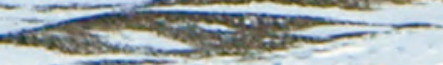

C)

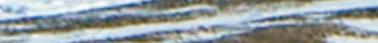




\section{Contents}

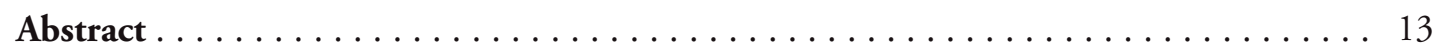

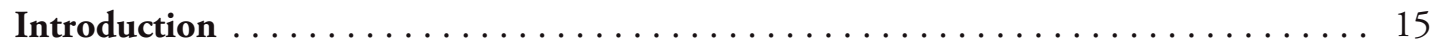

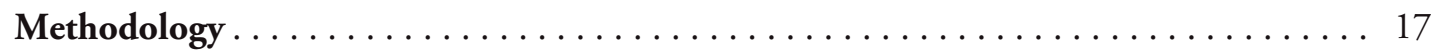

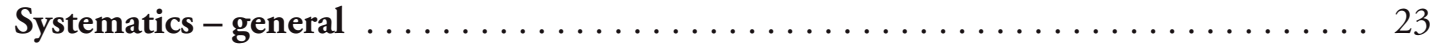

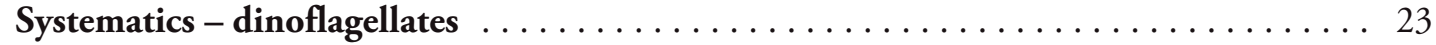

Division Dinoflagellata

Class Dinophyceae

Genus Achilleodinium Eaton $1976 \ldots \ldots \ldots \ldots \ldots \ldots \ldots \ldots \ldots \ldots$

Achilleodinium biformoides (Eisenack 1954) Eaton 1976

Genus Adnatosphaeridium Williams \& Downie 1966a . . . . . . . . . . . . . . 23

Adnatosphaeridium vittatum Williams \& Downie 1966a

Genus Alisocysta Stover \& Evitt 1978 . . . . . . . . . . . . . . . . . . . . . 24

Alisocysta circumtabulata (Drugg 1967) Stover \& Evitt 1978

Alisocysta margarita (Harland 1979a) Harland 1979a

Genus Alterbidinium Lentin \& Williams 1985 emend. nov. ................. 24 Alterbidinium acutulum (Wilson 1967a) Lentin \& Williams 1985

Alterbidinium biaperturum (McIntyre 1975) comb. nov.

Alterbidinium? bicellulum (Islam 1983a) Lentin \& Williams 1985

Alterbidinium ioannidesii Pearce 2010

Alterbidinium varium Kirsch 1991

Genus Apectodinium (Costa \& Downie 1976) Lentin \& Williams 1977a emend. Williams, Damassa, Fensome \& Guerstein in Fensome et al. 2009 . . . . . . . . . . . . . 26 Apectodinium homomorphum (Deflandre \& Cookson 1955) Lentin \& Williams 1977a Apectodinium parvum (Alberti 1961) Lentin \& Williams 1977a

Apectodinium quinquelatum (Williams \& Downie 1966b) Costa \& Downie 1979

Genus Aptea Eisenack 1958 . . . . . . . . . . . . . . . . . . . . . . . . 27 Aptea polymorpha Eisenack 1958

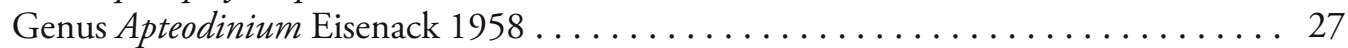

Apteodinium australiense (Deflandre \& Cookson 1955) Williams 1978 Apteodinium spiridoides Benedek 1972

Genus Areoligera Lejeune-Carpentier 1938 . . . . . . . . . . . . . . . . . 28

Areoligera circumsenonensis Fensome et al. 2009

Areoligera gippingensis Jolley 1992

Genus Areosphaeridium Eaton 1971 . . . . . . . . . . . . . . . . . . . . . . 29

Areosphaeridium diktyoplokum (Klumpp 1953) Eaton 1971

Genus Atopodinium Drugg 1978 . . . . . . . . . . . . . . . . . . . . . . . . . 29

Atopodinium cf. haromense Thomas \& Cox 1988

Genus Axiodinium Williams et al. in Fensome et al. 2009 . . . . . . . . . . . . . . . 29

Axiodinium augustum (Harland 1979b) Williams et al. 2015

Genus Batiacasphaera Drugg 1970 ... . . . . . . . . . . . . . . . . . . . . . 29

Batiacasphaera micropapillata Stover 1977

Genus Batioladinium Brideaux 1975 . . . . . . . . . . . . . . . . . . 30

Batioladinium jaegeri (Alberti 1961) Brideaux 1975

Genus Callaiosphaeridium Davey \& Williams 1966a ................... 30

Callaiosphaeridium asymmetricum (Deflandre \& Courteville 1939)

Davey \& Williams 1966a 
Genus Cannosphaeropsis Wetzel 1933a . . . . . . . . . . . . . . . . . . . 30

Cannosphaeropsis passio de Verteuil \& Norris 1996

Genus Cerebrocysta Bujak in Bujak et al. $1980 \ldots \ldots \ldots \ldots \ldots \ldots \ldots \ldots \ldots$. . . . . . . 31

Cerebrocysta bartonensis Bujak in Bujak et al. 1980

Cerebrocysta magna Bujak 1994 .

Genus Cerodinium Vozzhennikova 1963 .......................... 31

Cerodinium diebelii (Alberti 1959) Lentin \& Williams 1987

Cerodinium glabrum (Gocht 1969) Fensome et al. 2009

Cerodinium kangiliense Nøhr-Hansen \& Heilmann-Clausen 2001

Cerodinium speciosum (Alberti 1959) Lentin \& Williams 1987

Cerodinium striatum (Drugg 1967) Lentin \& Williams 1987

Genus Charlesdowniea Lentin \& Vozzhennikova 1989 emend. Williams et al. 2015 . . 32

Charlesdowniea coleothrypta (Williams \& Downie 1966b)

Lentin \& Vozzhennikova 1989

Genus Chatangiella Vozzhennikova 1967 emend. nov. .................. 32

Chatangiella decorosa (McIntyre 1975) Lentin \& Williams 1976

Chatangiella madura Lentin \& Williams 1976

Chatangiella tripartita (Cookson \& Eisenack 1960a) Lentin \& Williams 1976

Genus Chiropteridium Gocht 1960 emend. nov. ................... 34

Chiropteridium galea (Maier 1959) Sarjeant 1983

Chiropteridium gilbertii sp. nov.

Genus Chlamydophorella Cookson \& Eisenack 1958 . . . . . . . . . . . . . . . 35

Chlamydophorella nyei Cookson \& Eisenack 1958

Chlamydophorella cf. nyei Cookson \& Eisenack 1958

Genus Chytroeisphaeridia (Sarjeant 1962) Downie \& Sarjeant 1965 . . . . . . . . . 36

Chytroeisphaeridia hadra sp. nov.

Genus Cleistosphaeridium Davey et al. 1966 ....................... 36

Cleistosphaeridium diversispinosum Davey et al. 1966

Cleistosphaeridium elegantulum sp. nov.

Cleistosphaeridium palmatum sp. nov.

Cleistosphaeridium polypetellum (Islam 1983b) Stover \& Williams 1995

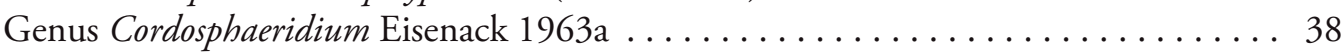

Cordosphaeridium cantharellus (Brosius 1963) Gocht 1969

Cordosphaeridium delimurum Fensome et al. 2009

Cordosphaeridium fibrospinosum Davey \& Williams 1966a

Cordosphaeridium funiculatum Morgenroth 1966a

Cordosphaeridium gracile (Eisenack 1954) Davey \& Williams 1966a

Cordosphaeridium inodes (Klumpp 1953) Eisenack 1963a

Genus Cribroperidinium Neale \& Sarjeant 1962 . . . . . . . . . . . . . . . . . . . . . . . . . . 39

Cribroperidinium giuseppei (Morgenroth 1966a) Helenes 1984

Genus Cyclonephelium Deflandre \& Cookson 1955 . . . . . . . . . . . . . . . . . . 39

Cyclonephelium distinctum (Deflandre \& Cookson 1955) Jansonius 1986

Genus Dapsilidinium Bujak et al. 1980 . . . . . . . . . . . . . . . . . . . . . . . 40

Dapsilidinium pseudocolligerum (Stover 1977) Bujak et al. 1980

Dapsilidinium pseudoinsertum sp. nov.

Dapsilidinium simplex (White 1842) Bujak et al. 1980 
Genus Deflandrea Eisenack 1938

Deflandrea borealis sp. nov.

Deflandrea denticulata Alberti 1959

Deflandrea galeata (Lejeune-Carpentier 1942) Lentin \& Williams 1973

Deflandrea majae (Schiøler 1993) comb. nov.

Deflandrea oebisfeldensis Alberti 1959

Deflandrea phosphoritica Eisenack 1938

Genus Dinogymnium Evitt et al. 1967

Dinogymnium longicorne (Vozzhennikova 1967) Harland 1973

Genus Diphyes Cookson 1965 nom. cons.

Diphyes brevispinum Bujak 1994

Diphyes colligerum (Deflandre \& Cookson 1955) Cookson 1965

Diphyes ficusoides Islam 1983a

Genus Disphaerogena Wetzel 1933a ........................... 43

Disphaerogena carposphaeropsis Wetzel 1933a

Genus Eatonicysta Stover \& Evitt 1978 . . . . . . . . . . . . . . . . . . . . . . . . . . . . . 43

Eatonicysta furensis (Heilmann-Clausen in Heilmann-Clausen \& Costa 1989)

Stover \& Williams 1995

Eatonicysta ursulae (Morgenroth 1966a) Stover \& Evitt 1978

Genus Enneadocysta Stover \& Williams $1995 \ldots \ldots \ldots \ldots \ldots \ldots \ldots \ldots \ldots$

Enneadocysta magna Fensome et al. 2007

Genus Eocladopyxis Morgenroth 1966a . . . . . . . . . . . . . . . . . 44

Eocladopyxis peniculata Morgenroth 1966a

Genus Evittosphaerula Manum 1979 emend. Damassa 1997 . . . . . . . . . . . . 44

Evittosphaerula? foraminosa sp. nov.

Genus Fibrocysta Stover \& Evitt 1978 . . . . . . . . . . . . . . . . . . 45

Fibrocysta bipolaris (Cookson \& Eisenack 1965a) Stover \& Evitt 1978

Genus Gillinia Cookson \& Eisenack 1960a . . . . . . . . . . . . . . . . . 45

Gillinia hymenophora Cookson \& Eisenack 1960a

Genus Ginginodinium Cookson \& Eisenack 1960a . . . . . . . . . . . . . . 45

Ginginodinium? flexidentatum sp. nov.

Genus Glaphyrocysta Stover \& Evitt 1978 . . . . . . . . . . . . . . . . . . 46

Glaphyrocysta divaricata (Williams \& Downie 1966a) Stover \& Evitt 1978

Glaphyrocysta exuberans (Deflandre \& Cookson 1955 ex Eaton 1976)

Stover \& Evitt 1978

Glaphyrocysta retiintexta Cookson 1965

Glaphyrocysta texta (Bujak 1976) Stover \& Evitt 1978

Glaphyrocysta vicina (Eaton 1976) Stover \& Evitt 1978

Genus Habibacysta Head et al. 1989 . . . . . . . . . . . . . . . . . . . . . . . . 47

Habibacysta tectata Head et al. 1989

Genus Hapsocysta Davey 1979 . . . . . . . . . . . . . . . . . . . . . . . . 47

Hapsocysta? benteae Nøhr-Hansen 1993

Genus Heteraulacacysta Drugg \& Loeblich Jr. 1967 . . . . . . . . . . . . . . . . . 48

Heteraulacacysta porosa Bujak in Bujak et al. 1980

Genus Heterosphaeridium Cookson \& Eisenack 1968 . . . . . . . . . . . . . . . . 48

Heterosphaeridium bellii Radmacher et al. 2014

Heterosphaeridium difficile (Manum \& Cookson 1964) Ioannides 1986

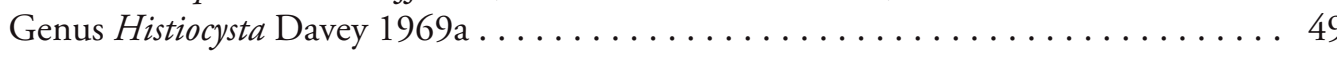

Histiocysta palla Davey 1969a

Genus Homotryblium Davey \& Williams 1966a . 
Homotryblium abbreviatum Eaton 1976

Homotryblium tenuispinosum Davey \& Williams 1966a

Genus Hystrichokolpoma Klumpp 1953 . . . . . . . . . . . . . . . . . . . . .

Hystrichokolpoma cinctum Klumpp 1953

Hystrichokolpoma globulus Michoux 1985

Genus Hystrichosphaeridium Deflandre 1937 . . . . . . . . . . . . . . . . . . . . . 50

Hystrichosphaeridium quadratum sp. nov.

Hystrichosphaeridium tubiferum (Ehrenberg 1838) Deflandre 1937

Genus Hystrichosphaeropsis Deflandre 1935 . . . . . . . . . . . . . . . . . . . 50

Hystrichosphaeropsis perforata Schiøler 1993

Hystrichosphaeropsis quasicribrata (Wetzel 1961) Gocht 1976

Genus Hystrichostrogylon Agelopoulos 1964 . . . . . . . . . . . . . . . . . . . . . 51

Hystrichostrogylon digitus sp. nov.

Genus Impagidinium Stover \& Evitt 1978 . . . . . . . . . . . . . . . . . . . . . 51

Impagidinium victorianum (Cookson \& Eisenack 1965b) Stover \& Evitt 1978

Genus Impletosphaeridium Morgenroth 1966a . . . . . . . . . . . . . . . . . . . . . 52

Impletosphaeridium apodastum sp. nov.

Genus Isabelidinium Lentin \& Williams 1977b . . . . . . . . . . . . . . . . . . . . . 52

Isabelidinium cooksoniae (Alberti 1959) Lentin \& Williams 1977b

Isabelidinium cretaceum (Cookson 1956) Lentin \& Williams 1977b

Isabelidinium microarmum (McIntyre 1975) Lentin \& Williams 1977b

Genus Kiokansium Stover \& Evitt 1978 . . . . . . . . . . . . . . . . . . . . . . . 53

Kiokansium williamsii Singh 1983

Genus Kleithriasphaeridium Davey 1974 .......................... 54

Kleithriasphaeridium mantellii (Davey \& Williams 1966a) comb. nov.

Genus Laciniadinium McIntyre 1975 . . . . . . . . . . . . . . . . . . . . . . . . . . . . . . 54

Laciniadinium arcticum (Manum \& Cookson 1964) Lentin \& Williams 1980

Genus Lentinia Bujak in Bujak et al. 1980 . . . . . . . . . . . . . . . . . . . 55

Lentinia serrata Bujak in Bujak et al. 1980

Genus Licracysta Fensome et al. 2007 . . . . . . . . . . . . . . . . . . . . . . . . . 55

Licracysta corymbus Fensome et al. 2007

Licracysta? semicirculata (Morgenroth 1966b) Fensome et al. 2007

Genus Lingulodinium Wall 1967 . . . . . . . . . . . . . . . . . . . . . 55

Lingulodinium funginum (Morgenroth 1966a) Islam 1983a

Lingulodinium machaerophorum (Deflandre \& Cookson 1955) Wall 1967

Genus Nyktericysta Bint 1986 . . . . . . . . . . . . . . . . . . . . . . . . . . 56

Nyktericysta davisii Bint 1986

Nyktericysta dictyophora He Chengquan et al. 1992

Nyktericysta tripenta (Bint 1986) Fensome et al. 2009

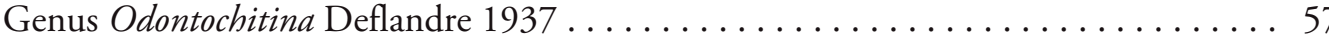

Odontochitina ancala Bint 1986

Odontochitina costata Alberti 1961

Odontochitina porifera Cookson 1956

Genus Oligosphaeridium Davey \& Williams 1966a . . . . . . . . . . . . . . . . . . 57

Oligosphaeridium albertense (Pocock 1962) Davey \& Williams 1969

Oligosphaeridium pulcherrimum (Deflandre \& Cookson 1955)

Davey \& Williams 1966a

Oligosphaeridium totum Brideaux 1971

Genus Operculodinium Wall 1967 . . . . . . . . . . . . . . . . . . . . . . . . . 58

Operculodinium centrocarpum (Deflandre \& Cookson 1955) Wall 1967 
Genus Palaeocystodinium Alberti 1961

Palaeocystodinium bulliforme Ioannides 1986

Palaeocystodinium golzowense Alberti 1961

Palaeocystodinium teespinosum Fensome et al. 2009

Genus Palaeohystrichophora Deflandre 1935 . . . . . . . . . . . . . . . . . . . . 59

Palaeohystrichophora infusorioides Deflandre 1935

Genus Palaeoperidinium Deflandre 1934 ex Sarjeant 1967 . . . . . . . . . . . . . . 59

Palaeoperidinium pyrophorum (Ehrenberg 1838 ex Wetzel 1933b) Sarjeant 1967

Genus Palynodinium Gocht 1970 . . . . . . . . . . . . . . . . . . . . . . . 60

Palynodinium grallator Gocht 1970

Genus Petalodinium Williams et al. 2015 ........................ 60

Petalodinium condylos (Williams \& Downie 1966b) Williams et al. 2015

Genus Phelodinium Stover \& Evitt 1978 . . . . . . . . . . . . . . . . . . . . . 61

Phelodinium kozlowskii (Górka 1963) Lindgren 1984

Genus Phthanoperidinium Drugg \& Loeblich Jr. 1967 . . . . . . . . . . . . . . . . . . 61

Phthanoperidinium coreoides (Benedek 1972) Lentin \& Williams 1976

Phthanoperidinium levimurum Bujak in Bujak et al. 1980

Phthanoperidinium multispinum Bujak in Bujak et al. 1980

Phthanoperidinium regale Bujak 1994

Phthanoperidinium stockmansii (de Coninck 1975) Lentin \& Williams 1977a

Genus Piladinium Williams et al. 2015 . . . . . . . . . . . . . . . . . . . 62

Piladinium columna (Michoux 1988) Williams et al. 2015

Piladinium edwardsii (Wilson 1967b) Williams et al. 2015

Genus Pseudoceratium Gocht 1957 . . . . . . . . . . . . . . . . . . . . . . . 63

Pseudoceratium sp.

Genus Raphidodinium Deflandre $1936 \ldots \ldots \ldots \ldots \ldots \ldots \ldots$. . . . . . . . . . . 63

Raphidodinium fucatum Deflandre 1936

Genus Reticulatosphaera Matsuoka $1983 \ldots \ldots \ldots \ldots \ldots \ldots \ldots . \ldots \ldots . \ldots . \ldots 6$

Reticulatosphaera actinocoronata (Benedek 1972) Bujak \& Matsuoka 1986

Genus Rhombodinium Gocht 1955 emend. Williams et al. in Fensome et al. 2009 . . . 64

Rhombodinium draco Gocht 1955

Rhombodinium porosum Bujak 1979

Genus Rottnestia Cookson \& Eisenack 1961a ........................ 64

Rottnestia borussica (Eisenack 1954) Cookson \& Eisenack 1961a

Genus Scalenodinium gen. nov. . . . . . . . . . . . . . . . . . . . . . . . . . 64

Scalenodinium scalenum sp. nov.

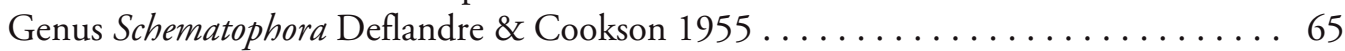

Schematophora speciosa Deflandre \& Cookson 1955

Genus Senegalinium Jain \& Millepied 1973 . . . . . . . . . . . . . . . . . . 65

Senegalinium iterlaaense Nøhr-Hansen \& Heilmann-Clausen 2001

Genus Senoniasphaera Clarke \& Verdier 1967 ...................... 65

Senoniasphaera inornata (Drugg 1970) Stover \& Evitt 1978

Senoniasphaera microreticulata Brideaux \& McIntyre 1975

Senoniasphaera rotundata Clarke \& Verdier 1967

Genus Simplicidinium gen. nov. ......................... 66

Simplicidinium insolitum (Eaton 1976) comb. nov.

Genus Sophismatia Williams et al. $2015 \ldots \ldots \ldots \ldots \ldots \ldots \ldots \ldots \ldots$. . . . . . . . 67

Sophismatia tenuivirgula (Williams \& Downie 1966b) Williams et al. 2015

Genus Spinidinium Cookson \& Eisenack 1962 . . . . . . . . . . . . . . . . . 67

Spinidinium echinoideum (Cookson \& Eisenack 1960a) Lentin \& Williams 1976 
Genus Spiniferites Mantell 1850

Spiniferites ovatus Matsuoka 1983

Spiniferites pseudofurcatus (Klumpp 1953) Sarjeant 1970

Spiniferites scabrosus (Clarke \& Verdier 1967) Lentin \& Williams 1975

Genus Spongodinium Deflandre 1936.

Spongodinium delitiense (Ehrenberg 1838) Deflandre 1936

Spongodinium grossum (Manum \& Cookson 1964) comb. nov.

Spongodinium obscurum (Manum \& Cookson 1964) comb. nov.

Genus Stichodinium Williams et al. 2015 ... . . . . . . . . . . . . . . . . . . . . 69

Stichodinium lineidentatum (Deflandre \& Cookson 1955) Williams et al. 2015

Genus Subtilisphaera Jain \& Millepied 1973 . . . . . . . . . . . . . . . . . . . . . . . 69

Subtilisphaera perlucida (Alberti 1959) Jain \& Millepied 1973

Genus Surculosphaeridium Davey et al. 1966 emend. nov. . . . . . . . . . . . . . . 70

Surculosphaeridium convocatum sp. nov.

Genus Talladinium Williams, Damassa, Fensome \& Guerstein in Fensome et al. 2009 . 71

Talladinium? clathratum (Eisenack 1938) Williams, Damassa, Fensome \& Guerstein

in Fensome et al. 2009

Talladinium pellis sp. nov.

Genus Tanyosphaeridium Davey \& Williams 1966a ................... 71

Tanyosphaeridium xanthiopyxides (Wetzel 1933a ex Deflandre 1937)

Stover \& Evitt 1978

Genus Taurodinium gen. nov. ........................... 72

Taurodinium granulatum sp. nov.

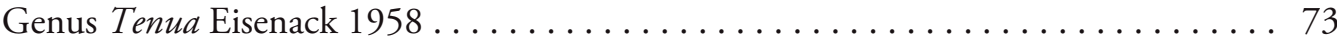

Tenua hystrix Eisenack 1958

Genus Thalassiphora Eisenack \& Gocht 1960 . . . . . . . . . . . . . . . . . . . . . . 73

Thalassiphora delicata Williams \& Downie 1966a

Thalassiphora fenestrata Liengjarern et al. 1980

Thalassiphora pelagica (Eisenack 1954) Eisenack \& Gocht 1960

Genus Trichodinium Eisenack \& Cookson 1960 . . . . . . . . . . . . . . . . . . . 73

Trichodinium castanea Deflandre 1935 ex Clarke \& Verdier 1967

Genus Trithyrodinium Drugg 1967 ........................... 74

Trithyrodinium? conservatum sp. nov.

Trithyrodinium evittii Drugg 1967

Trithyrodinium quinqueangulare Marheinecke 1992

Trithyrodinium suspectum (Manum \& Cookson 1964) Davey 1969b

Genus Tuberculodinium Wall 1967 ... . . . . . . . . . . . . . . . . . . . . . 75

Tuberculodinium vancampoae (Rossignol 1962) Wall 1967

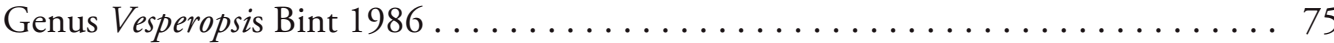

Vesperopsis longicornis (Batten \& Lister 1988) Harding 1990

Genus Wallodinium Loeblich Jr. \& Loeblich III 1968 . . . . . . . . . . . . . . . . . 76

Wallodinium luna (Cookson \& Eisenack 1960a) Lentin \& Williams 1973

Genus Wetzeliella Eisenack 1938 emend. Williams et al. in Fensome et al. 2009 . . . . 76

Wetzeliella articulata Wetzel in Eisenack 1938 emend. Williams et al. in

Fensome et al. 2009

Genus Xenascus Cookson \& Eisenack 1969 . . . . . . . . . . . . . . . . . . . . . . . 76

Xenascus ceratioides (Deflandre 1937) Lentin \& Williams 1973

Xenascus wetzelii Slimani 1996 ex Slimani 2001a

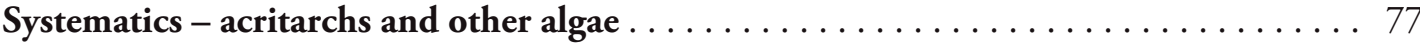

Genus Fromea (Cookson \& Eisenack 1958) Yun Hyesu 1981 . . . . . . . . . . . . . . 77 
Fromea nicosia Jansonius 1989

Fromea quadrangularis sp. nov.

Genus Microsphaeridium Benedek 1972 . . . . . . . . . . . . . . . . . 78

Microsphaeridium ancistroides Benedek 1972

Genus Palambages Wetzel 1961 . . . . . . . . . . . . . . . . . . . . . . . 78

Palambages spp.

Genus Paralecaniella Cookson \& Eisenack 1970a . . . . . . . . . . . . . . . . . . 78

Paralecaniella indentata (Deflandre \& Cookson 1955) Cookson \& Eisenack 1970a

Genus Pediastrum Meyen 1829 . . . . . . . . . . . . . . . . . . . . . 78

Pediastrum spp.

Genus Tetraporina Naumova 1950 . . . . . . . . . . . . . . . . . . . . . . . 79

Tetraporina sp. A

Tetraporina sp. B

Systematics - miospores and fungal elements $\ldots \ldots \ldots \ldots \ldots \ldots \ldots \ldots \ldots \ldots \ldots \ldots \ldots$

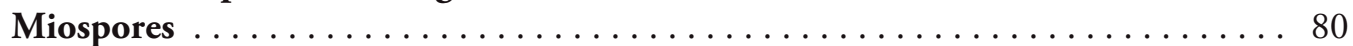

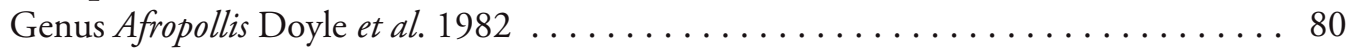

Afropollis sp.

Genus Appendicisporites Weyland \& Krieger 1953 . . . . . . . . . . . . . . 80

Appendicisporites potomacensis Brenner 1963

Appendicisporites unicus (Markova in Ivanova \& Markova 1961) Singh 1964

Genus Aquilapollenites Rouse 1957 . . . . . . . . . . . . . . . . . . . . . . 80

Aquilapollenites quadrilobus Rouse 1957 emend. Braman 2013

Genus Azolla Lamarck in Lamarck et al. 1783 . . . . . . . . . . . . . . . . . . . . . . . 81 Azolla spp.

Genus Baculatisporites Pflug \& Thomson in Thomson \& Pflug 1953 . . . . . . . . 81

Baculatisporites crenulatus sp. nov.

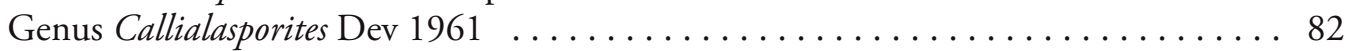

Callialasporites dampieri (Balme 1957) Dev 1961

Callialasporites obrutus Norris 1969

Genus Caryapollenites Raatz 1938 ex Potonié 1960 ..................... 82

Caryapollenites inelegans Nichols \& Ott 1978

Caryapollenites veripites (Wilson \& Webster 1946) Nichols \& Ott 1978

Genus Cerebropollenites Nilsson 1958 . . . . . . . . . . . . . . . . . . . 83

Cerebropollenites mesozoicus (Couper 1958) Nilsson 1958

Genus Chenopodipollis Krutzsch 1966 ........................ 83

Chenopodipollis sp.

Genus Cicatricosisporites Potonié \& Gelletich 1933 . . . . . . . . . . . . . . 83

Cicatricosisporites minutaestriatus (Bolkhovitina 1961) Pocock 1964

Cicatricosisporites ornatus Srivastava 1972

Genus Cicatricososporites Pflug \& Thomson in Thomson \& Pflug 1953 . . . . . . . 83

Cicatricososporites eocenicus (Selling 1944) Jansonius \& Hills 1976

Genus Compositoipollenites Potonié 1951 ex Potonié 1960 .................. 84

Compositoipollenites sp. B of Williams \& Brideaux 1975

Genus Corsinipollenites Nakoman 1965 ........................ 84

Corsinipollenites oculusnoctis (Thiergart 1940) Nakoman 1965

Genus Extratriporopollenites Pflug in Thomson \& Pflug 1952 ex Pflug in

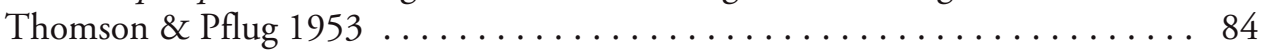

Extratriporopollenites spp.

Genus Graminidites Cookson 1947 ex Potonié 1960 ..................... 84

Graminidites sp. A. of Williams \& Brideaux 1975 
Genus Momipites Wodehouse 1933 ....................... 86

Momipites annellus Nichols \& Ott 1978

Momipites coryloides Wodehouse 1933

Genus Osmudacidites Couper 1953 ............................. 84

Osmundacidites wellmannii Couper 1953

Genus Parviprojectus Mtchedlishvili in Samoilovitch \& Mtchedlishvili 1961emend.

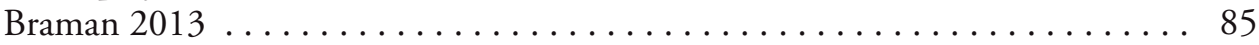

Parviprojectus reticulatus Mtchedlishvili in Samoilovitch \& Mtchedlishvili 1961

Genus Parvisaccites Couper 1958 . . . . . . . . . . . . . . . . . . . . . . . 85

Parvisaccites amplus Brenner 1963

Parvisaccites radiatus Couper 1958

Genus Periporopollenites Pflug \& Thomson in Thomson \& Pflug 1953 . . . . . . . . . 85

Periporopollenites sp.

Genus Pistillipollenites Rouse 1962 ... . . . . . . . . . . . . . . . . 86

Pistillipollenites macgregorii Rouse 1962

Genus Quercoidites Potonié et al. 1950 ex Potonié 1960 ................... 86

Quercoidites sp.

Genus Rugubivesiculites Pierce 1961 ........................ 86

Rugubivesiculites spp.

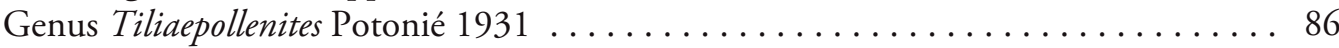

Tiliaepollenites crassipites (Wodehouse 1933) comb. nov.

Tiliaepollenites sp. A

Genus Translucentipollis Khlonova 1961 . . . . . . . . . . . . . . . . . 87

Translucentipollis contiguus (Tschudy 1969) Braman 2013

Genus Wodehouseia Stanley 1961 ... . . . . . . . . . . . . . . . . . . . 87

Wodehouseia spinata Stanley 1961

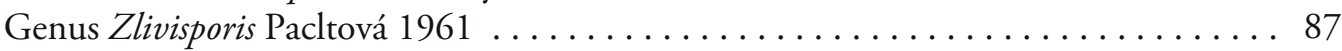

Zlivisporis spp.

Genus Zonalapollenites Pflug in Thomson \& Pflug 1953 . . . . . . . . . . . . 87

Zonalapollenites igniculus (Potonié 1931) Thomson \& Pflug 1953

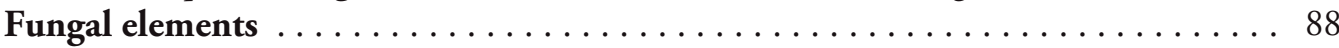

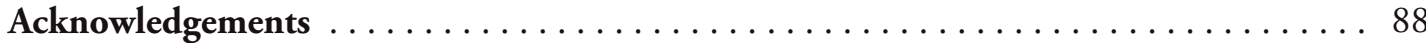

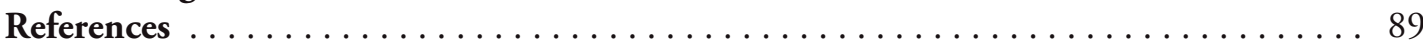

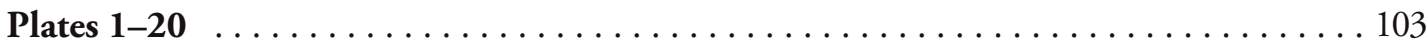





\section{Abstract}

Fensome, R.A., Nøhr-Hansen, H., \& Williams. G.L. 2016: Cretaceous and Cenozoic dinoflagellate cysts and other palynomorphs from the western and eastern margins of the Labrador-Baffin Seaway.

Geological Survey of Denmark and Greenland Bulletin 36, 143 pp.

New palynological analysis of samples from 13 offshore wells on the Canadian Margin and six wells on the West Greenland Margin has led to a new event biostratigraphic framework for CretaceousCenozoic strata of the Labrador Sea - Davis Strait - Baffin Bay (Labrador-Baffin Seaway) region. This framework is based on about 150 dinoflagellate cyst taxa and 30 acritarch, algal, fungal and plant microfossil (mostly miospore) taxa. In the systematics we include three new genera of dinocysts (Scalenodinium, Simplicidinium and Taurodinium), 16 new species of dinocysts (Chiropteridium gilbertii, Chytroeisphaeridia hadra, Cleistosphaeridium elegantulum, Cleistosphaeridium palmatum, Dapsilidinium pseudoinsertum, Deflandrea borealis, Evittosphaerula? foraminosa, Ginginodinium? flexidentatum, Hystrichosphaeridium quadratum, Hystrichostrogylon digitus, Impletosphaeridium apodastum, Scalenodinium scalenum, Surculosphaeridium convocatum, Talladinium pellis, Taurodinium granulatum and Trithyrodinium? conservatum), four emendations of dinocyst genera (Alterbidinium, Chatangiella, Chiropteridium and Surculosphaeridium), six new combinations for dinocyst species (Alterbidinium biaperturum, Deflandrea majae, Kleithriasphaeridium mantellii, Simplicidinium insolitum, Spongodinium grossum, Spongodinium obscurum), one new acritarch species (Fromea quadrangularis), one new miospore species (Baculatisporites crenulatus) and one new combination for miospores (Tiliaepollenites crassipites). Most of the taxa included provide age information, almost exclusively last occurrences (range 'tops'), but some are useful mainly for environmental interpretations. Collectively, they provide a powerful tool for helping to establish the geological history of the Labrador-Baffin Seaway.

Authors' addresses

R.A.F. \& G.L.W., Geological Survey of Canada (Atlantic), Natural Resources Canada, PO Box 1006, 1 Challenger Drive, Dartmouth, Nova Scotia B2Y 4A2, Canada. E-mail: rob.fensome@canada.ca

H.N.-H., Geological Survey of Denmark and Greenland, Øster Voldgade 10, DK-1350 Copenhagen K, Denmark. 


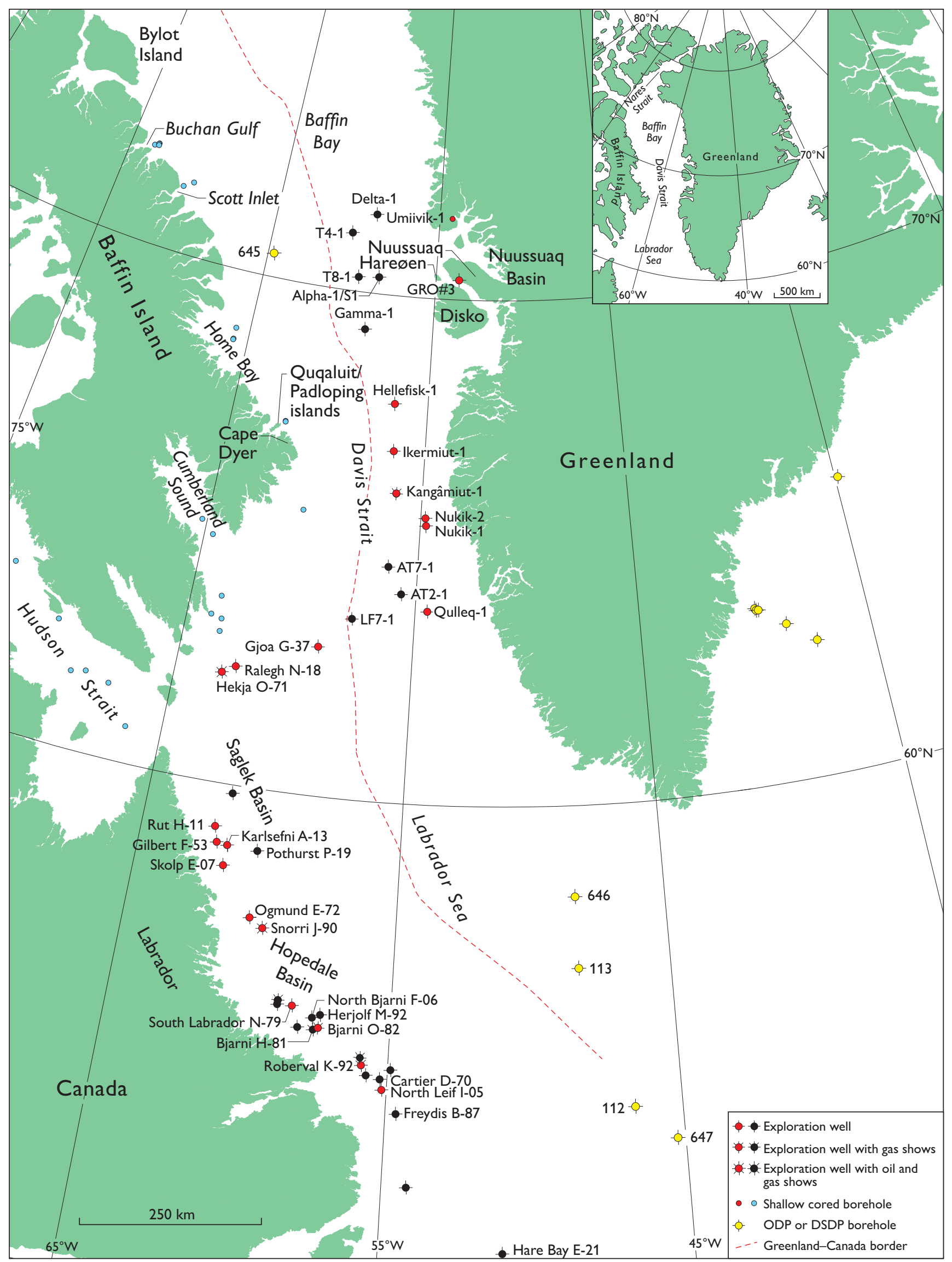




\section{Introduction}

Canada and Greenland are separated, from south to north, by the Labrador Sea, the Davis Strait, Baffin Bay (which we call collectively the Labrador-Baffin Seaway), and the narrow Nares Strait (Fig. 1). The LabradorBaffin Seaway stretches from about $52^{\circ} \mathrm{N}$ on to $75^{\circ} \mathrm{N}$, a distance of roughly $2500 \mathrm{~km}$. Timing for the geological evolution of the seaway's margin is based primarily on biostratigraphic analyses from exploration wells drilled between 1971 and 2000 on the Labrador Margin, off West Greenland and in the Davis Strait, and from some shallow cored boreholes drilled in Baffin Bay in the 1980s (Figs 1, 2). These drilling activities revealed thick successions of Mesozoic-Cenozoic sediments on both sides of the seaway, and the lithostratigraphy of these has developed in tandem with the biostratigraphy. Additional information comes from numerous Cretaceous-Cenozoic outcrop sections in the Nuussuaq Basin in West Greenland, a few onshore sections in Labrador and on Baffin and Bylot islands (Figs 1,2), and from ODP Leg 105, hole 645 in Baffin Bay (Fig. 1). Although previous work on these materials has provided a good stratigraphic foundation for the CretaceousCenozoic of the region (Fig. 3), renewed petroleum exploration interest in recent years has revealed gaps in our knowledge and a need to correlate the western and eastern margins of the seaway. Consequently, for the past decade, the Geological Survey of Denmark and Greenland (GEUS) and the Geological Survey of Cana- da (Atlantic) (GSCA) have undertaken an exhaustive palynological study, based on palynological analysis of more than 2000 well samples. The objectives of this work have been to refine age control and palaeoenvironmental interpretations on a regional scale, with the ultimate goal of contributing fundamentally to an understanding of the geological history of the seaway and its petroleum systems. A significant finding has been that the orderly story of five regional unconformities (Fig. 3) is not as clear-cut as has been previously thought (see Fig. 4 and Nøhr-Hansen et al. 2016 for details).

Dinoflagellate cysts (dinocysts) are the primary palynomorph group evaluated, but spores and pollen (miospores), a fern microspore massula (Azolla), algal microfossils and acritarchs have also been used. Our new age determinations (Figs 5, 6, in pocket; see Nøhr-Hansen et al. 2016 for further details) are more precise than those of previous studies because of advances made in refining stratigraphic ranges, especially of dinocysts (e.g. Williams et al. 2004). Moreover, the number of species for which we have detailed stratigraphic information has increased immeasurably since early studies in the region in the 1970s.

This paper focuses on the systematic treatment of palynomorphs observed in the study, thereby underpinning the results presented in the companion bulletin (Nøhr-Hansen et al. 2016), but also facilitating future work in the region and further afield.

\section{Facing page:}

Fig. 1. Map of the Labrador-Baffin Seaway showing the location of relevant wells, boreholes and onshore localities; wells and boreholes shown in red were used in this study. The cored borehole GGU 400712 is $2 \mathrm{~km}$ ENE of Umiivik-1; Annertuneq is on the north coast of Nuussuaq. Inset map shows the regional context of the Labrador-Baffin Seaway between Canada and Greenland. 


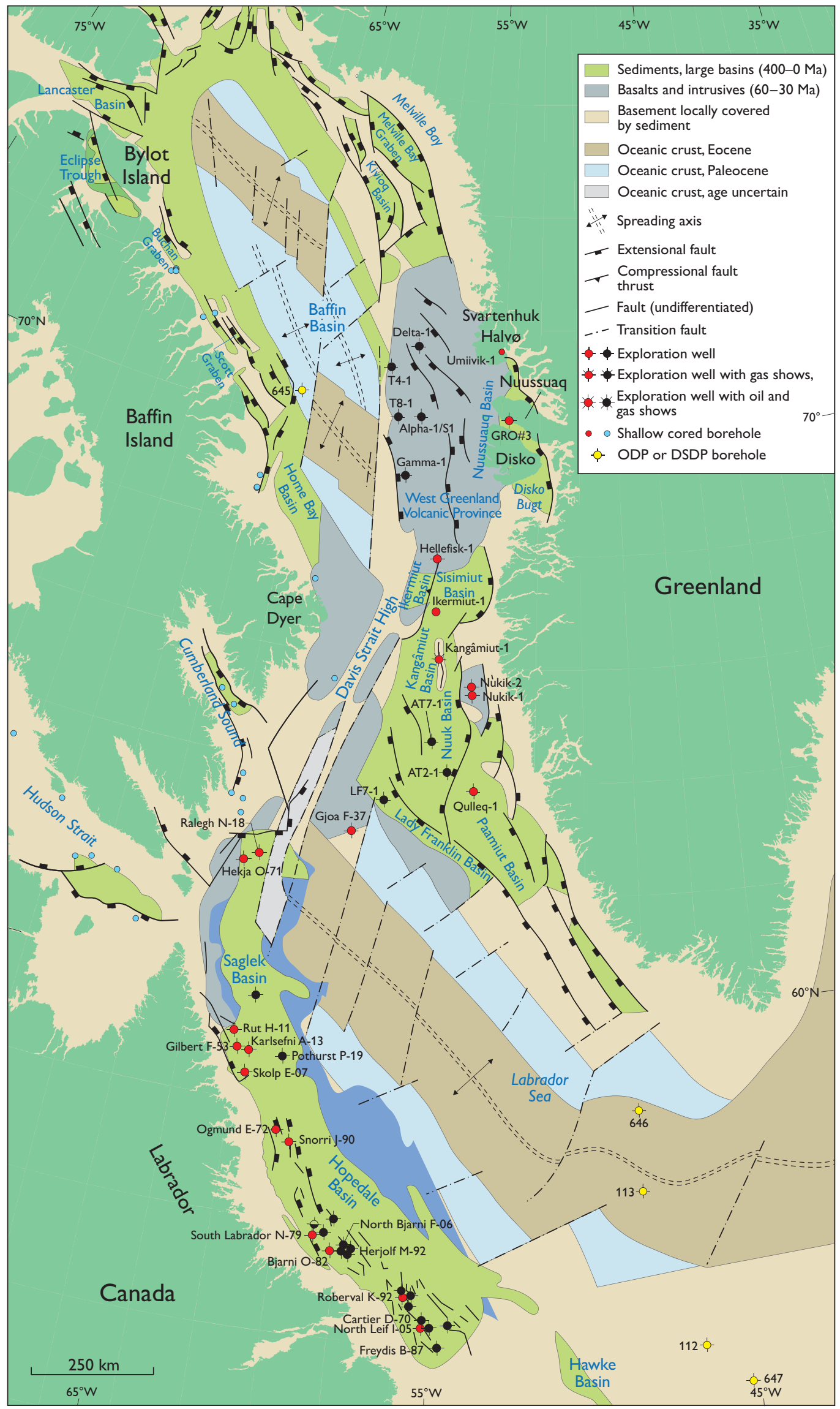




\section{Methodology}

The study is based on samples from ditch cuttings, sidewall cores and conventional cores from onshore and offshore wells and boreholes, and on outcrop samples (Figs 1, 2). Most of the samples were processed for palynology between 1990 and 2006, using standard techniques for concentrating palynomorphs. However, many of the sidewall-core samples are represented only by oil-company slides produced in the late 1970s to 1980s and are of variable quality.

Using transmitted light microscopy, qualitative and quantitative analyses were carried out of the dinocysts, acritarchs and pollen and spores, the results and implications of which are detailed in Nøhr-Hansen et al. (2016). The systematic section below is accompanied by plates; sample number, slide number and England Finder coordinates for each specimen are provided. The slides from the six offshore West Greenland wells, Hellefisk-1, Ikermiut-1, Kangâmiut-1, Nukik-1, Nukik2 and Qulleq-1 are kept at GEUS. GEUS also processed samples from six offshore Canadian wells, Gjoa G-37,
Hekja O-71, North Leif I-05, Ogmund E-72, Ralegh $\mathrm{N}-18$ and Skolp E-07. One set of palynology slides from Gjoa G-37, Hekja O-71 and Ralegh N-18 is housed at GEUS (Copenhagen) and one set is housed at the Geological Survey of Canada (Atlantic), Dartmouth, Nova Scotia, Canada. A set from each well is also curated at the Canada-Nova Scotia Offshore Petroleum Board, Dartmouth, Nova Scotia. The Geological Survey of Canada has processed samples from all the Labrador Margin wells, which include Bjarni O-82, Gilbert F-53, Kalsefni A-13, Roberval K-92, Rut H-11, Snorri J-90 and South Labrador N-79. One set of palynology slides from these wells is housed at the Geological Survey of Canada (Atlantic), Dartmouth, Nova Scotia. Another set is curated at the Canada - Newfoundland and Labrador Offshore Petroleum Board (CNLOPB) in St. Johns, Newfoundland. Also on file with CNLOPB are sets of GEUS-prepared slides from North Leif I-05, Ogmund E-72 and Skolp E-07. 
Fig. 3. Stratigraphic framework of the Mesozoic-Cenozoic rocks of the Labrador and West Greenland margins and adjacent onshore sections; modified from Gregersen et al. (2013). The Labrador Margin stratigraphy is from Dickie et al. (2011), with unconformities from McWhae (1981). The West Greenland Margin stratigraphy is based on well stratigraphic studies by Rolle (1985), Nøhr-Hansen (2003) and Sønderholm et al. (2003); the deeper sub-well section is based on Chalmers et al. (1993), Chalmers \& Pulvertaft (2001) and Sørensen (2006). The Nuussuaq Basin stratigraphy is from Storey et al. (1998), Dam et al. (2009), Pedersen \& Nøhr-Hansen (2014) and Larsen et al. (2015); these papers and this study are the source of the inferred ages. The southeast Baffin Island stratigraphy is from Burden \& Langille (1990) and Pedersen et al. (2002), the Home Bay and Scott Inlet seabed samples from MacLean et al. (2014) and the north Baffin Island stratigraphy is based on Jackson et al. (1978) and McWhae (1981). The Bylot Island stratigraphy is from Miall (1986), Waterfield (1989), and Harrison et al. (1999). The timescale (Ma) and magnetostratigraphy are from Gradstein et al. (2012). Fm: Formation (formal). fm: formation (informal). Mb: Member (formal). mb: member (informal). Unc.: unconformity.
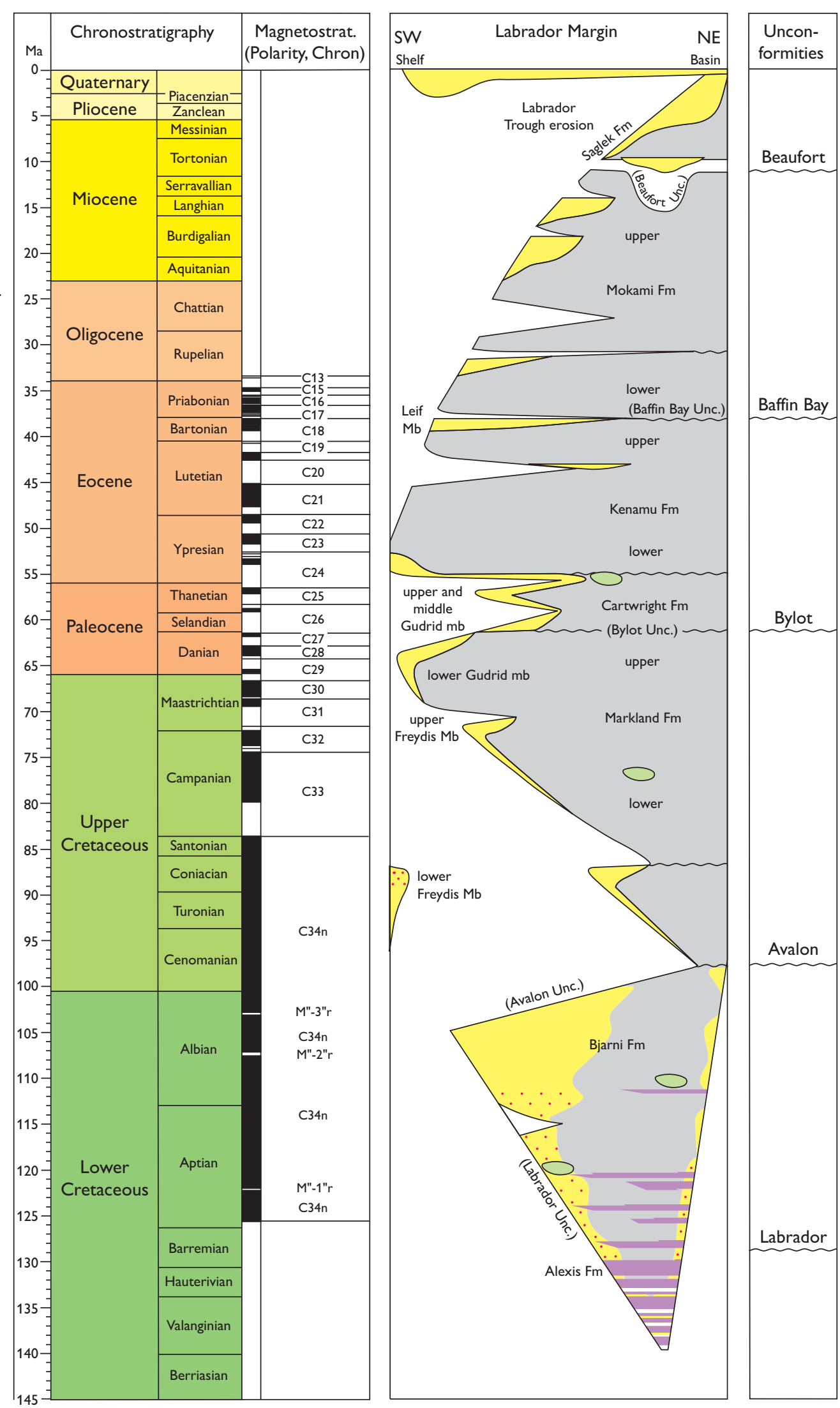

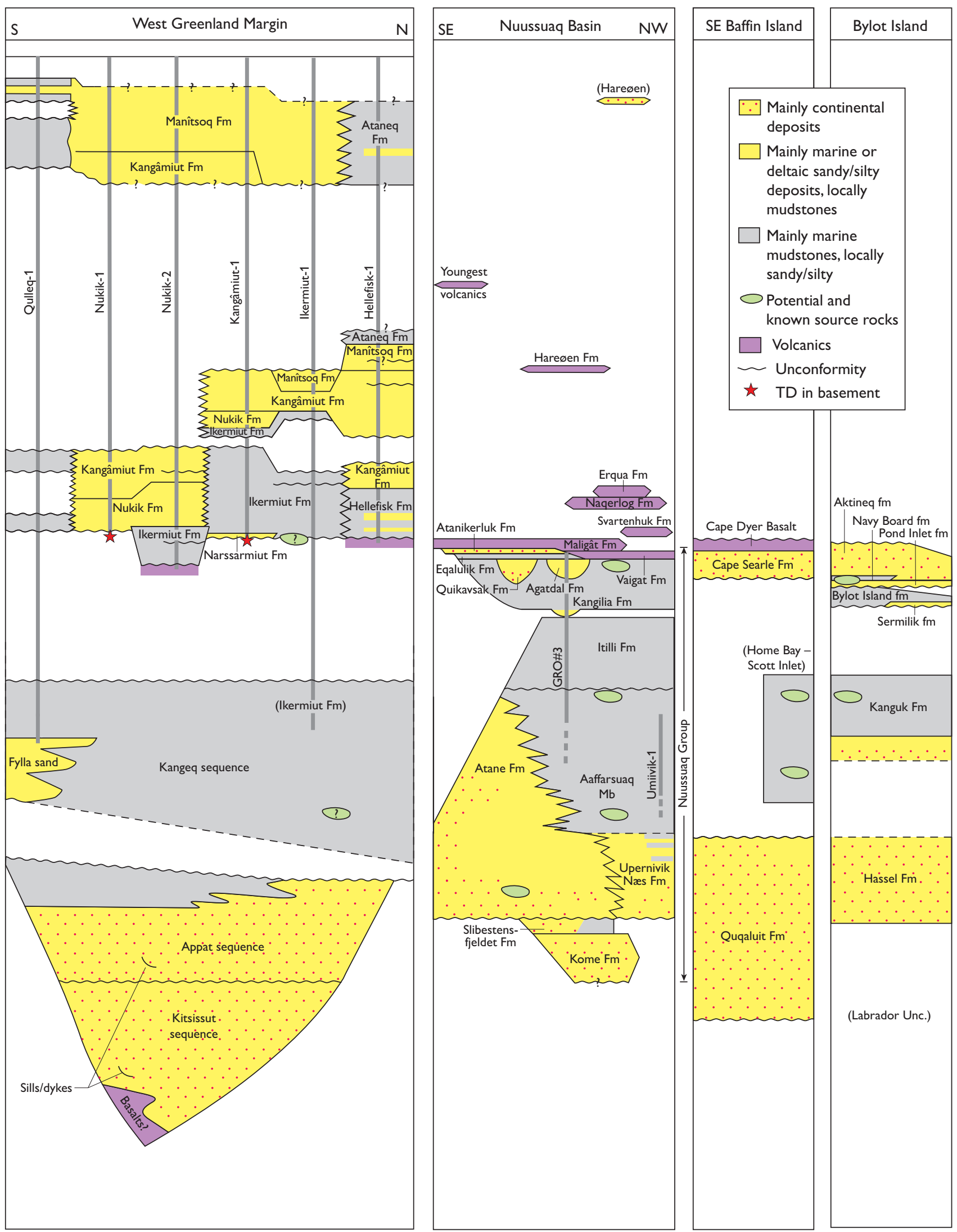


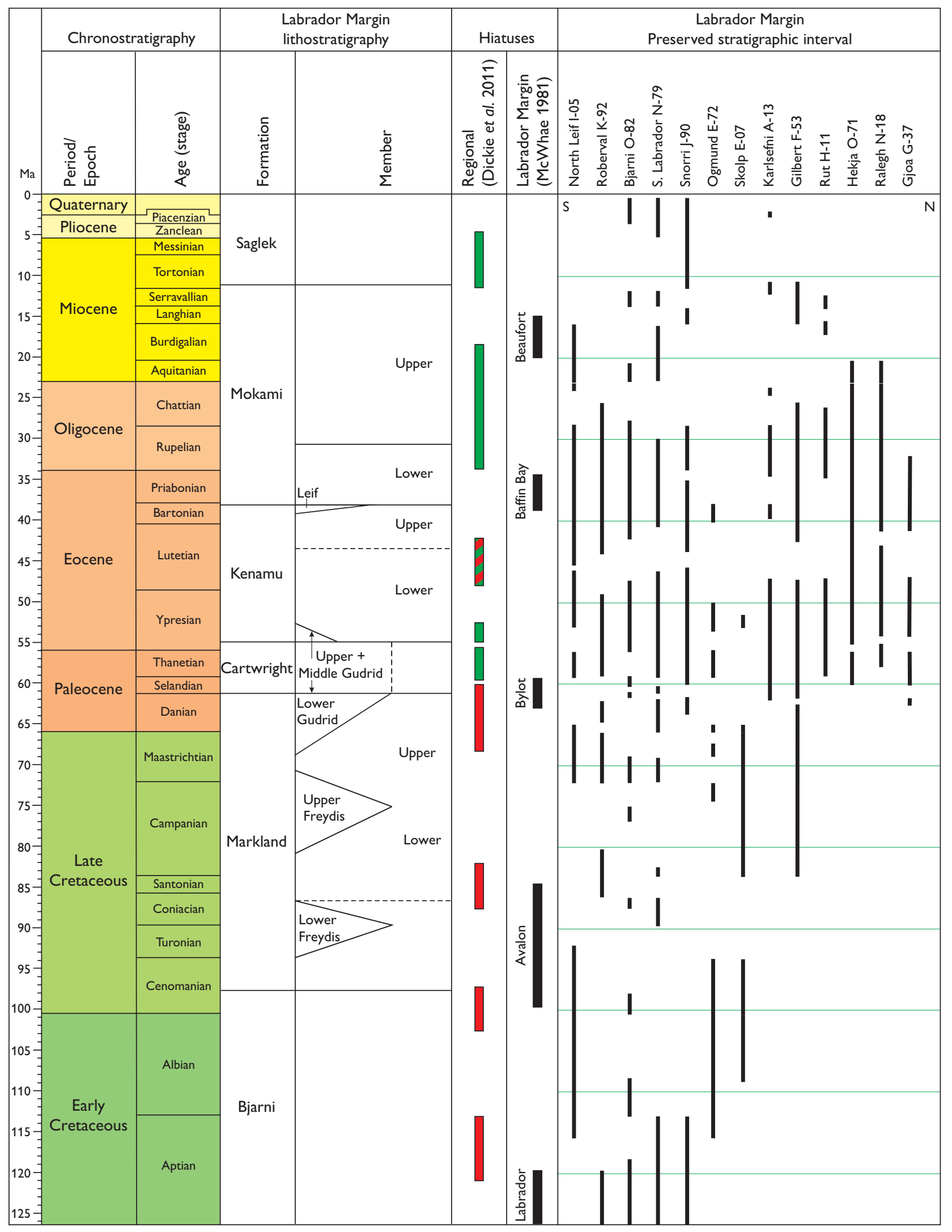




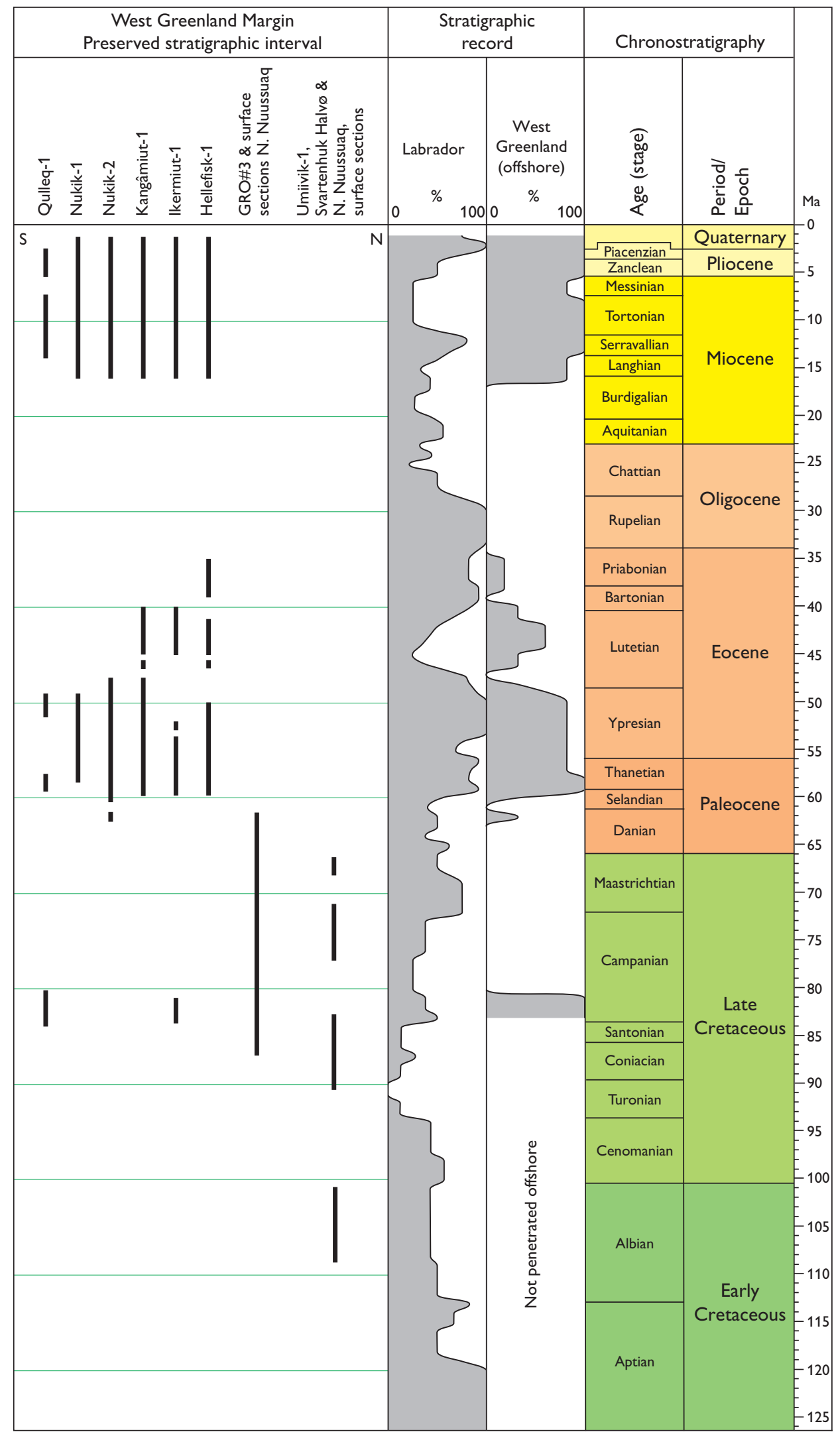

Fig. 4. Ages of strata preserved in wells on the Labrador, Baffin and Greenland Margins, compared with the hiatuses linked to unconformities reported in the literature. Dickie et al. (2011) recognised a number of unconformities in two or more of three regions - the Southwest Greenland Shelf, the Labrador Shelf and the Jeanne d'Arc Basin, offshore Newfoundland (red, all three regions; green, two regions). McWhae (1981) named five unconformities on the Labrador Margin; the hiatuses associated with these unconformities indicated here are estimates by McWhae (1981) based on an unspecified timescale and thus should be considered approximate. The 'cumulative preservation' plots (right) depict schematically the proportion of wells that contain sediments of a specified age, based on one millionyear slots; note that these calculations only include wells that extend down to/beyond the relevant stratigraphic level. 


\begin{tabular}{|c|c|c|c|c|}
\hline & Suborder & Family & Subfamily & Genera \\
\hline \multirow{20}{*}{ 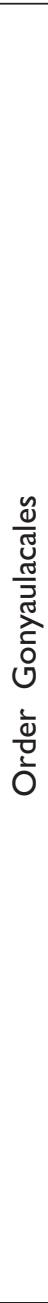 } & Rhaetogonyaulacineae & Rhaetogonyaulacaceae & & \\
\hline & \multirow{3}{*}{ Cladopyxiineae } & Cladopyxiaceae & & Gillinia, Histiocysta \\
\hline & & \multirow{2}{*}{ Pareodiniaceae } & Pareodinioideae & \\
\hline & & & Broomeoideae & Batioladinium \\
\hline & \multirow{6}{*}{ Gonyaulacineae } & \multirow{4}{*}{ Gonyaulacaceae } & Leptodinioideae & $\begin{array}{l}\text { Eatonicysta, Kleithriasphaeridium, } \\
\text { Oligosphaeridium }\end{array}$ \\
\hline & & & Cribroperidinioideae & $\begin{array}{l}\text { Achilleodinium, Apteodinium, Cordosphaeridium, } \\
\text { Cribroperidinium, Dapsilidinium, Diphyes, } \\
\text { Disphaerogena, Hapsocysta, Hystrichokolpoma, } \\
\text { Lingulodinium, Operculodinium, Spongodinium, } \\
\text { Thalassiphora }\end{array}$ \\
\hline & & & Gonyaulacoideae & $\begin{array}{l}\text { Cannosphaeropsis, Evittosphaerula, } \\
\text { Hystrichosphaeropsis, Hystrichostrogylon, } \\
\text { Impagidinium, Rottnestia, Spiniferites, }\end{array}$ \\
\hline & & & Uncertain & $\begin{array}{l}\text { Callaiosphaeridium, Cerebrocysta, } \\
\text { Chytroeisphaeridia, Fibrocysta, Habibacysta, } \\
\text { Kiokansium, Surculosphaeridium, Trichodinium }\end{array}$ \\
\hline & & Ceratocoryaceae & & \\
\hline & & Areoligeraceae & & $\begin{array}{l}\text { Adnatosphaeridium, Areoligera, Areosphaeridium, } \\
\text { Chiropteridium, Cleistosphaeridium, Enneadocysta, } \\
\text { Glaphyrocysta, Heterosphaeridium, Licracysta } \\
\text { Palynodinium, Schematophora, Senonaisphaera, } \\
\text { Tenua }\end{array}$ \\
\hline & Ceratiineae & Ceratiaceae & & $\begin{array}{l}\text { Aptea, Nyktericysta, Odontochitina, Pseudoceratium, } \\
\text { Taurodinium, Vesperopsis, Xenascus }\end{array}$ \\
\hline & \multirow{6}{*}{ Goniodomineae } & \multirow{5}{*}{ Goniodomaceae } & Goniodomoideae & Heteraulacacysta \\
\hline & & & Gambierdiscoideae & \\
\hline & & & Helgolandinioideae & Tuberculodinium \\
\hline & & & Pyrodinioideae & $\begin{array}{l}\text { Alisocysta, Eocladopyxis, Homotryblium } \\
\text { Hystrichosphaeridium }\end{array}$ \\
\hline & & & Uncertain & \\
\hline & & Pyrocystaceae & & \\
\hline & & Heterodiniaceae & & \\
\hline & & Crypthecodiniaceae & & \\
\hline & Uncertain & Uncertain & & $\begin{array}{l}\text { Atopodinium, Batiacasphaera, Chlamydophorella, } \\
\text { Impletosphaeridium?, Raphidodinium, } \\
\text { Reticulatosphaera, Simplicidinium, } \\
\text { Tanyosphaeridium, Wallodinium }\end{array}$ \\
\hline \multirow{12}{*}{ 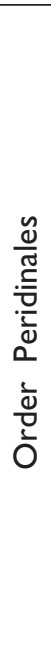 } & Heterocapsineae & Heterocapsaceae & & \\
\hline & Glenodiniineae & Glenodiniaceae & & \\
\hline & \multirow{10}{*}{ Peridiniineae } & \multirow{7}{*}{ Peridiniaceae } & Palaeoperidinioideae & $\begin{array}{l}\text { Ginginodinium?, Laciniadinium, } \\
\text { Palaeoperidinium, Phthanoperidinium? } \\
\text { Subtilisphaera }\end{array}$ \\
\hline & & & Deflandreoideae & $\begin{array}{l}\text { Alterbidinium, Cerodinium, Chatangiella, Deflandrea, } \\
\text { Isabelidinium, Lentinia, Palaeocystodinium, } \\
\text { Scalenodinium?, Senegalinium, Spinidinium, } \\
\text { Trithyrodinium }\end{array}$ \\
\hline & & & Calciodinelloideae & \\
\hline & & & Ovoidinioideae & \\
\hline & & & Wetzelielloideae & $\begin{array}{l}\text { Apectodinium,Axiodinium, Charlesdowniea, } \\
\text { Petalodinium, Piladinium, Rhombodinium, } \\
\text { Sophismatia, Stichodinium, Talladinium, Wetzeliella }\end{array}$ \\
\hline & & & Lithoperidinioideae & \\
\hline & & & Peridinioideae & \\
\hline & & \multirow{2}{*}{ Protoperidinioideae } & Protoperidinioideae & Phelodinium \\
\hline & & & Diplopsalioideae & \\
\hline & & Podolampaceae & & \\
\hline
\end{tabular}

Fig. 7. Suprageneric affiliation of peridiniphycidean genera treated systematically in the present study. The only non-peridiniphycidean dinocyst genus treated in this study is Dinogymnium, which belongs to the subclass Gymnodiniophycidae, order Ptychodiscales, family Ptychodiscaceae, subfamily Dinogymnioideae. 


\section{Systematics - general}

Presentation of the systematic taxonomic descriptions includes subsections on dinocysts, acritarchs and other algae, miospores, and fungi. For pragmatic reasons, genera are arranged alphabetically within each section. For the dinocysts, a tabulation of suprageneric affinities is provided (Fig. 7). Under individual taxa, all synonyms are listed but those already indicated and credited to earlier works in Fensome et al. (2008) are generally not discussed further. The term 'synopsis' is used for a statement of what we consider the essential defining features of the genus. Unless otherwise clearly indicated, the synopses given herein should not be understood to represent emendations. Only those emendations that we agree with or consider helpful are cited.

\section{Systematics - dinoflagellates}

\author{
Division Dinoflagellata (Bütschli 1885) \\ Fensome et al. 1993 \\ Class Dinophyceae Pascher 1914
}

Genus Achilleodinium Eaton 1976

Type. Eisenack 1954, plate 11, fig. 18, as Hystrichosphaeridium biformoides.

1976 Achilleodinium Eaton, p. 234.

Remarks. We follow the synopsis of Fensome et al. (2009, p. 11) for this genus.

\section{Achilleodinium biformoides (Eisenack 1954)}

Eaton 1976

(Plate 1, figs 1-3)

1954 Hystrichosphaeridium biformoides Eisenack, p. 68 , plate 11 , figs $16-20$.

1965 Baltisphaeridium biformoides (Eisenack) Downie \& Sarjeant, p. 87.
All ages refer to their definition in the latest revision of the geological timescale (Gradstein et al. 2012). For most species, an age is indicated for significant events in its stratigraphical range, usually a range top or 'Last Occurrence' (LO). The statement 'not plotted' refers to the fact that a particular taxon was not plotted in the summary event charts (Figs 5, 6, in pocket); the reasons for not plotting some taxa include a taxon's sparsity or long and unhelpful range (though it may be helpful palaeoenvironmentally. Because the data are based mainly on cuttings samples, a taxon's range bottom or 'First Occurrence' (FO) is rarely used. We occasionally refer to the LAD of a species, its 'Last Appearance Datum', which refers to its youngest global occurrence.

1965 Hystrichokolpoma biformoides (Eisenack) Rozen, p. 308.

1976 Achilleodinium biformoides (Eisenack) Eaton, p. 234.

1980 Florentinia biformoides (Eisenack) - Duxbury, p. 121.

Age. LO: Ypresian.

\section{Genus Adnatosphaeridium Williams \& Downie 1966a}

Type. Williams \& Downie 1966a, plate 24, fig. 7, textfig. 56, as Adnatosphaeridium vittatum.

1966a Adnatosphaeridium Williams \& Downie, p. 215.

Remarks. Stancliffe \& Sarjeant (1990, p. 199-200) emended the diagnosis of Adnatosphaeridium but did not change the concept of the generic circumscription. Here, we follow the synopsis provided by Fensome et al. (2009, p. 11). 


\section{Adnatosphaeridium vittatum Williams \& Downie 1966a}

(Plate 1, figs 4, 8)

1966a Adnatosphaeridium vittatum Williams \& Downie, p. 15, plate 24, fig. 7; text-fig. 56.

1966a Adnatosphaeridium multispinosum Williams \& Downie, p. 216, 217, plate 24, fig. 5; text-fig. 57.

Age. LO: late Bartonian. Not plotted.

Remarks. Following Fensome et al. (2009, p. 13), the species Adnatosphaeridium multispinosum is considered a taxonomic synonym of Adnatosphaeridium vittatum.

\section{Genus Alisocysta Stover \& Evitt 1978}

Type. Drugg 1967, plate 1, fig. 12, as Eisenackia circumtabulata.

1978 Alisocysta Stover \& Evitt, p. 15, 16.

1979a Agerasphaera Harland, p. 28, 29; illegitimate name, having the same type as Alisocysta.

Synopsis. Goniodomacean (pyrodinioid) cysts that are proximate and subspherical. The tabulation is reflected by penitabular ridges or septa that delineate the plates, including the cingulars and some or all of the sulcals. The archaeopyle is apical, with the formula $A_{\left(1-4^{\prime}\right)}$; operculum free.

Remarks. Quattrocchio \& Sarjeant (2003, p. 144) considered Alisocysta to be a taxonomic junior synonym of Eisenackia. However, as stated by Stover \& Evitt (1978, p. 42) "Alisocysta has parasutural [i.e. penitabular] ridges or septa rather than depressions as in Eisenackia" and Alisocysta is thus retained here as a separate genus, including both the type, Alisocysta circumtabulata, and Alisocysta margarita.

\section{Alisocysta circumtabulata (Drugg 1967) Stover \& Evitt 1978}

(Plate 1, figs 6,7)

1967 Eisenackia circumtabulata Drugg, p. 15, plate 1, figs 12, 13.

1978 Hystrichokolpoma circumtabulatum (Drugg) Schumacker-Lambry, p. 42.

1978 Alisocysta circumtabulata (Drugg) - Stover \& Evitt, p. 16. 1979a Agerasphaera circumtabulata (Drugg) Harland, p. 29; illegitimate combination as the generic name Agerasphaera is illegitimate.

2003 Eisenackia circumtabulata (Drugg) Quattrocchio \& Sarjeant, p. 146.

Age. LO: earliest Thanetian.

\section{Alisocysta margarita (Harland 1979a) Harland 1979a}

(Plate 1, figs 5, 9)

1979a Agerasphaera margarita Harland, p. 29, 31, 33 , plate 1 , figs 1-12; plate 2, figs $1-10$.

1979a Alisocysta margarita (Harland) - Harland, p. 35.

2003 Eisenackia margarita (Harland) Quattrocchio \& Sarjeant, p. 146.

Age. LO: earliest Thanetian.

\section{Genus Alterbidinium Lentin \& Williams 1985 emend. nov.}

Type. Vozzhennikova 1967, plate 77, fig. 2, as Albertia recticornis.

1967 Albertia Vozzhennikova, p. 150, 151; illegitimate name.

1976 Alterbia Lentin \& Williams, p. 47, 48; illegitimate name.

1985 Alterbidinium Lentin \& Williams, p. 14.

Emended description. Peridiniacean (deflandreoid) cysts that are proximate and peridinioid, usually elongate, in outline. The antapical horns are always asymmetrically arranged, the left horn being larger. Bicavate. The pericyst surface is generally atabulate, smooth, or with low ornament; the cingulum is commonly indicated, if only marginally. The periarchaeopyle is intercalary or combination intercalary-precingular; always involving an isoto stenodeltaform hexa plate $2 \mathrm{a}$ and commonly plate $4^{\prime \prime}$, the operculum remaining attached posteriorly; archaeopyle $\mathrm{I}_{2 \mathrm{a}} @$ or $\left(\mathrm{I}_{2 \mathrm{a}} \mathrm{P}_{4^{\prime \prime}}\right) @$.

Remarks. In their emendation of Alterbidinium, KhowajaAteequzzaman et al. (1991, p. 38) stated: "archaeopyle intercalary, independently developed on periphragm and endophragm, dissimilar in shape; periarchaeopyle hexa 2a, steno/iso-deltaform, perioperculum free or adnate; endoarchaeopyle hexa 2a, eury-deltaform, endoperculum adnate." However, they did not base their emendation on 
the type of the genus. Thus, in the emendation proposed here, the synopsis of Fensome et al. (2009, p. 13) is largely repeated: it emphasised the nature of the archaeopyle, which is formed from the iso- to stenodeltaform hexa plate 2 a, but may also involve plate $4^{\prime \prime}$. Almost invariably, the operculum remains attached posteriorly.

Genera with similar morphologies to Alterbidinium include Spinidinium, Diconodinium, Cerodinium, Chatangiella and Isabelidinium. Spinidinium and Diconodinium differ from Alterbidinium in having a spinate periphragm. Cerodinium has a large isodeltaform periarchaeopyle, an endoarchaeopyle formed from the loss of one to three anterior intercalary plates, and generally long apical and antapical horns. Chatangiella is distinguished by its generally omegaform $2 \mathrm{a}$ and partite cingulum, although Fensome et al. (2009, p. 19) stated that the archaeopyle could vary between isodeltaform and iso-omegaform. We now consider that Chatangiella should be restricted to taxa that possess an iso- or lati-omegaform archaeopyle. Similarly, Isabelidinium is restricted to taxa with an iso- to latiomegaform 2a plate and archaeopyle. However, some species presently included in Isabelidinium can have thetaform or isodeltaform 2a plates and archaeopyles.

The present morphological differences used to separate the deflandreoid genera are in large part unsatisfactory. Perhaps a more effective approach would be to adopt the methodological approach used by Williams et al. (2015) in their reclassification of the wetzelielloideans. Following this example, the deflandroidean genera would be differentiated primarily on the nature of the archaeopyle, since this reflects differences in tabulation pattern. This then follows the categories recognised by Lentin \& Williams (1976) and expanded by Bujak \& Davies (1983). These are omegaform, thetaform and deltaform modes, with steno-, isoand lati- subcategories. Such an approach would not be a perfect solution as there are clearly gradations, but it would make the generic distinctions more meaningful, and is considered here the best solution.

In the spirit of this approach, herein we informally use Isabelidinium for forms having a lati- to iso-omegaform archaeopyle. A formal revision would require many of the species now included in that genus to be transferred to other existing or new genera. Indeed, a re-appraisal of all deflandreoidean taxa is deemed necessary, but is beyond the scope of the present paper, although as an initial step emendations are proposed for Alterbidinium and Chatangiella.

\section{Alterbidinium acutulum (Wilson 1967a) Lentin \& Williams 1985}

(Plate 1, figs 10, 11) 1967a Deflandrea acutula Wilson, p. 225, 226, figs 11, 12.

1967 Albertia curvicornis Vozzhennikova, p. 151, plate 76, figs 1-4.

1967 Albertia recticornis Vozzhennikova, p. 151, 152, plate 77 , figs $1-4$; plate 78 , figs $1-3$; plate 79 , figs 1,2 .

1976 Alterbia acutula (Wilson) - Lentin \& Williams, p. 48.

1976 Alterbia curvicornis (Vozzhennikova) - Lentin \& Williams, p. 49.

1976 Alterbia recticornis (Vozzhennikova) - Lentin \& Williams, p. 47.

1985 Alterbidinium acutulum (Wilson) - Lentin \& Williams, p. 14.

Age. LO: early Maastrichtian.

Remarks. Fensome \& Williams (2005, p. 9) recorded this species, in part, under the informal name 'Alterbidinium fleximorphum' because of the great variation shown by this species. It is now recognised that this variability should be encompassed within Alterbidinium acutulum.

Alterbidinium biaperturum (McIntyre 1975) comb. nov.

(Plate 1, figs 12-14)

1975 Deflandrea biapertura McIntyre, p. 66, plate 3, figs 5-8.

1976 Chatangiella? biapertura (McIntyre) - Lentin \& Williams, p. 53.

Age. LO: late Maastrichtian.

Remarks. This species is distinguished by an opening in the pericyst between the antapical horns. From the illustrations of the holotype in McIntyre (1975, plate 3, figs 5, 6), Alterbidinium (as Chatangiella?) biaperturum appears to possess a cingulum delineated by continuous ridges; the periarchaeopyle is extremely unusual, being distinctly deltaform on one lateral margin but, as $\mathrm{M}$. Pearce (personal communication 2015) has noted, possibly thetaform on the other lateral margin. Whether such asymmetry occurs in other specimens of this species is unknown. But regardless, the species is thus not assignable to Chatangiella. Lentin \& Williams (1976) were aware of these differences when provisionally including this taxon in Chatangiella, but did not consider assigning it to Alterbidinium. We herein transfer the species to Alterbidinium to more accurately reflect its morphology. 
Alterbidinium? bicellulum (Islam 1983a) Lentin \& Williams 1985

(Plate 1, figs 15, 16)

1983a Alterbia? bicellula Islam, p. 335, 336, plate 1, figs 6, 7 .

1985 Alterbidinium? bicellulum (Islam) - Lentin \& Williams, p. 14.

Age. LO: Lutetian, with a peak occurrence in the Ypresian.

Remarks. In the diagnosis for Alterbidinium? bicellulum (as Alterbia? bicellula), Islam (1983a, p. 336) stated that the archaeopyle was "... intercalary type I/I with standard hexa style operculum attached". This implies that the archaeopyle is isodeltaform, but it is not possible to confirm this from his illustrations (Islam 1983a, plate 1, figs $6,7,10,11)$. Islam (1983a) questionably assigned this species to Alterbia (now Alterbidinium) "because the epipericoel is not always communicative to the exterior, and its degree of cavation and the archaeopyle index do not match those prescribed for the genus. The degree of cavation and the archaeopyle index of this species also do not match those of other peridinioid genera that are differentiated on the basis of these features by Lentin $\&$ Williams (1976)." Taxa with an isodeltaform archaeopyle and an attached operculum are rare, especially in the Cenozoic. Thus we leave the species questionably in Alberbidinium.

Alterbidinium ioannidesii Pearce 2010

(Plate 1, Fig. 17)

1986 Dinoflagellate type E of Ioannides, p. 42, plate 23, figs 13-16.

2010 Alterbidinium ioannidesii Pearce, p. 66, 67, plate 1, figs 1-6.

Age. LO: early Campanian.

Remarks: This is an unusual species of Alterbidinium in displaying tabulation on the pericyst.

\section{Alterbidinium varium Kirsch 1991}

(Plate 1, figs 18, 19)

1991 Alterbidinium varium Kirsch, p. 98, 99, plate 19, figs 1-10; text-figs 46a-h, 47a, b.

Age. LO: Campanian.
Genus Apectodinium (Costa \& Downie 1976)

Lentin \& Williams 1977a emend. Williams,

Damassa, Fensome \& Guerstein in Fensome et al. 2009

Type. Deflandre \& Cookson 1955, plate 5, fig. 7, as

Wetzeliella homomorpha.

1976 Wetzeliella subgenus Apectodinium Costa \& Downie, p. 608.

1977a Apectodinium (Costa \& Downie 1976) Lentin \& Williams, p. 8.

2009 Apectodinium (Costa \& Downie) - emend. Williams, Damassa, Fensome \& Guerstein in Fensome et al., p. 13, 14.

Remarks. The emended diagnosis in Fensome et al. (2009, p. 13, 14) is followed here; this emphasised archaeopyle type and variability and the general absence of a pericoel except in the vicinity of the horns.

\section{Apectodinium homomorphum (Deflandre \& Cookson 1955) Lentin \& Williams 1977a}

(Plate 1, fig. 20)

1955 Wetzeliella homomorpha Deflandre \& Cookson, p. 254, plate 5, fig. 7; text-fig. 19.

1974 Hystrichosphaeridium caiobense Regali et al., p. 290, plate 24, fig. 4 .

1977a Apectodinium homomorphum (Deflandre \& Cookson) - Lentin \& Williams, p. 8.

1981 Apectodinium caiobense (Regali et al.) - Lentin \& Williams, p. 14.

1983a Apectodinium folliculum Islam, p. 336, 337, plate 1 , figs 8,9 .

Age. Peak: early Ypresian.

Remarks. Harland (1979b, p. 64) emended the diagnosis of this species, as Wetzeliella (Apectodinium) homomorphum, to "take into account the nature of the archaeopyle, cingular and sulcal details". A characteristic feature of Apectodinium homomorphum is the absence of horns, although Harland noted that incipient horns may be developed in the apical, lateral and antapical areas.

\section{Apectodinium parvum (Alberti 1961) Lentin \&} Williams 1977a

(Plate 2, figs 1-3)

1961 Wetzeliella parva Alberti, p. 8, 9, plate 1, figs 14-18; plate 12 , figs $10-12$. 
1976 Wetzeliella subgenus Apectodinium parva (Alberti) - Costa \& Downie, p. 608.

1977a Apectodinium parvum (Alberti) - Lentin \& Williams, p. 9.

Age. LO: earliest Ypresian.

Remarks. In his emendation of Apectodinium parvum, Harland (1979b, p. 65, 66) noted that lateral horns are absent and the processes may be intratabular or sutural. In his description he stated that "The horn development, prominent at the antapex, is variously developed with relation to the apical horn, which may or may not be present." The Labrador Margin specimens usually have an apical horn, but show considerable variation in length and width. Some of the Labrador Margin specimens have longer processes than those illustrated by Harland (1979b), with those of one specimen being 21 $\mu \mathrm{m}$. When longer, the processes are extremely delicate. However, forms with more robust processes also occur.

\section{Apectodinium quinquelatum (Williams \& Downie 1966b) Costa \& Downie 1979}

(Plate 2, fig. 4)

1948 Hystrichosphaeridium geometricum Pastiels, p. 41, plate 4, figs 1-5, 7-10, non Hystrichosphaeridium geometricum Deflandre 1942.

1966 betzeliella homomorphum var. quinquelata Williams \& Downie, p. 191, 192, plate 18, fig. 7.

1977a Wetzeliella homomorpha subsp. quinquelata (Williams \& Downie) - Lentin \& Williams, p. 8.

1979b Wetzeliella (Apectodinium) quinquelata (Williams \& Downie) - Harland, p. 67.

1979 Apectodinium quinquelatum (Williams \& Downie) - Costa \& Downie, p. 43.

Age. LO: Ypresian. Not plotted.

\section{Genus Aptea Eisenack 1958}

Type. Eisenack 1958, plate 22, fig. 5, as Aptea polymorpha.

1958 Aptea Eisenack, p. 393.

1966a Doidyx Sarjeant, p. 205.

\section{Aptea polymorpha Eisenack 1958}

(Plate 2, fig. 5)
1958 Aptea polymorpha Eisenack, p. 394, plate 22, figs 5-12; plate 24, fig. 5.

1986 Pseudoceratium polymorphum (Eisenack 1958) - Bint, p. 145.

Age. LO: Aptian.

Remarks. The ornamentation of this species is variable, ranging from coarsely reticulate to irregularly spinate.

\section{Genus Apteodinium Eisenack 1958}

Type. Eisenack 1958, plate 23, fig. 9, as Apteodinium granulatum.

1958 Apteodinium Eisenack, p. 385.

1961 Emslandia Gerlach, p. 171.

1971 Coniferatium Burgess, p. 80, 81.

Remarks. The synopsis for Apteodinium followed here is that provided in Fensome et al. (2009, p. 14), which noted that tabulation may sometimes be weakly reflected on the cyst wall.

\section{Apteodinium australiense (Deflandre \& Cookson 1955) Williams 1978}

(Plate 2, fig. 6)

1955 Gymnodinium australiense Deflandre \& Cookson, p. 248, plate 5, fig. 1.

1961 Gonyaulax tenuitabulata Gerlach, p. 159, plate 25, figs 10, 11; text-figs 1-3.

1965 Emslandia australiensis (Deflandre \& Cookson) - Nagy, p. 202; combination not validly published.

1965a Scriniodinium australiense (Deflandre \& Cookson) - Cookson \& Eisenack, p. 122.

1969 Gonyaulacysta tenuitabulata (Gerlach) - de Coninck, p. 23.

1978 Apteodinium australiense (Deflandre \& Cookson) - Williams, p. 794.

1978 Millioudodinium tenuitabulatum (Gerlach) Stover \& Evitt, p. 174.

1981 Emslandia crassimurata Benedek \& Sarjeant, p. 320, 322, fig. 1, nos 2, 4.

1984 Cribroperidinium tenuitabulatum (Gerlach) Helenes, p. 124.

1984a Rhynchodiniopsis tenuitabulata (Gerlach) Sarjeant, p. 76.

Age. LO: Rupelian. 
Remarks. Apteodinium australiense has a spongy wall, as does the holotype of Cribroperidinium tenuitabulatum. Moreover, the latter has at best weakly developed and barely discernible parasutural ridges. Hence, we consider Cribroperidinium tenuitabulatum to be a junior synonym of Apteodinium australiense.

\section{Apteodinium spiridoides Benedek 1972}

(Plate 2, figs 7, 8)

1972 Apteodinium spiridoides Benedek, p. 5, plate 2, fig. 1a, b; plate 15, figs 1-6.

1981 Emslandia spiridoides (Benedek) - Benedek \& Sarjeant, p. 318.

Age. LO: earliest Serravallian.

Remarks. In their emendation of Apteodinium spiridoides, Benedek \& Sarjeant $(1981$, p. 318, 319) noted the presence of an apical horn, the two-layered nature of the wall and the archaeopyle type. Jan du Chêne et al. (1986, p. 48) retained the species in Apteodinium.

\section{Genus Areoligera Lejeune-Carpentier 1938}

Type. Lejeune-Carpentier 1938, text-fig. 2, as Areoligera senonensis.

\section{Areoligera Lejeune-Carpentier, p. B164.}

Remarks. We agree with the synopsis for Areoligera provided by Fensome et al. (2009, p. 14) and their observations under remarks. Included in Areoligera are several species with overlapping morphology. This is primarily manifested in the shape and distribution of the process complexes and the complexity of the linkages between processes within an individual complex. Fensome et al. (2009, p. 15) introduced two terms for the distribution of the process complexes. The encircling condition is when complexes are, "....arcuate to annulate and occur on all the pre- and postcingular plates." In the disjunct condition, "...annulate to arcuate complexes are restricted to the dorsal surface, there is lateral development of linear complexes and the ventral surface (i.e. $6^{\prime \prime}$ and $\left.6^{\prime \prime \prime}\right)$ is devoid of complexes." Fensome et al. (2009, p. 15) define Areoligera gippingensis as a species with "encircling complex arrangement and predominantly trabecular connections." Following the specific differences recognised for species of Areoligera by these authors, it is concluded that all specimens with this general morphology studied here should be assigned to Areoligera gippingensis.
The genera Chiropteridium and Glaphyrocysta superficially resemble Areoligera, but neither Chiropteridium nor Glapyrocysta have distinct annulate or arcuate process complexes with basal ridges that delineate tabulation. However, Chiropteridium gilbertii does have intratabular processes or complexes. Chiropteridium differs from Areoligera primarily in having neither mid-dorsal nor midventral processes or membranes. Glaphyrocysta has nontabular or indistinctly contabular processes.

\section{Areoligera circumsenonensis Fensome et al. 2009} (Plate 2, fig. 9)

1966a Areoligera cf. senonensis of Williams \& Downie, p. 230, 231; text-fig. 64 A-C (not plate 25 , fig 6 , typographically mislabelled plate 26, fig. 6).

1969 Areoligera senonensis Lejeune-Carpentier Gocht, p. 56, plate 8, fig. 4a, b (?not figs 59); text-figs 40a, b, ?40c, d (not fig. 40e, f).

2009 Areoligera circumsenonensis Fensome et al., p. 15 , plate 1 , fig. $\mathrm{m}$.

Age. LO: early Lutetian. Not plotted.

Remarks. Areoligera circumsenonensis has processes like those of Areoligera senonensis but the process complexes are annular to arcuate on the large pre- and postcingular plates. In Areoligera gippingensis, the processes are interconnected along their length within, and occasionally between, complexes.

\section{Areoligera gippingensis Jolley 1992}

(Plate 2, figs 10, 11)

1966a Areoligera cf. medusettiformis of Williams \& Downie, p. 229, plate 25, fig. 4.

1976 Areoligera cf. medusettiformis of Eaton, p. 246, plate 3, fig. 7.

1992 Areoligera gippingensis Jolley, p. 26, 28, 30, 31 , plate 1 , figs $1-6$; plate 2 , figs $1-6$; textfigs $2 \mathrm{a}-\mathrm{d}, 3$.

Age. LO: late Ypresian. Peak: early Thanetian.

Remarks. Specimens of Areoligera gippingensis in Labrador Margin samples show considerable variability in the delineation of the process complexes. We have found that this species is gradational with Glaphyrocysta divaricata. The species can be common in the late Thanetian, but generally peaks in the early Thanetian. 


\section{Genus Areosphaeridium Eaton 1971}

Type. Klumpp 1953, plate 18, figs 3, 4, as Hystrichosphaeridium dictyoplokum.

1971 Areosphaeridium Eaton, p. 357, 358.

Synopsis. Chorate gonyaulacinean cysts with subspherical central body. Acavate. Processes mesotabular, solid, commonly fibroid, expanded clypeate and fenestrate to reticulate distally. The number of cingular processes is variable. Archaeopyle apical, with formula $\mathrm{A}_{\left(1-4^{\prime}\right)}$, operculum free.

Remarks. The synopsis is based on the emendation of Areosphaeridium by Stover \& Williams (1995, p. 100). Following Fensome et al. (2007), Areosphaeridium is considered an areoligeracean cyst related to Enneadocysta.

\section{Areosphaeridium diktyoplokum (Klumpp 1953) Eaton 1971}

(Plate 2, fig. 12)

1953 Hystrichosphaeridium diktyoplokum Klumpp, p. 392, plate 18, figs 3-7 (not plate 18, figs 8-10, which are now Cordosphaeridium latum).

1963a Cordosphaeridium diktyoplokum (Klumpp) Eisenack, p. 262.

1971 Areosphaeridium diktyoplokum (Klumpp) Eaton, p. 358, 359.

Age. LO: latest Priabonian.

\section{Genus Atopodinium Drugg 1978}

Type. Drugg 1978, plate 1, fig. 1, as Atopodinium prostatum.

1978 Atopodinium Drugg, p. 62.

1981 Maghrebinia Below, p. 22.

1987 Bejuia Stover \& Williams, p. 37.

Remarks. Masure (1991, p. 64) demonstrated that Atopodinium has a gonyaulacacean tabulation and that the archaeopyle of the type is apical, with the formula $A_{1-4}$, and with precingular accessory sutures; the operculum is attached.

\section{Atopodinium cf. haromense Thomas \& Cox 1988}

(Plate 2, fig. 13)

cf. 1988 Atopodinium haromense Thomas \& Cox, p. 319-321, 323, plate 1, figs 1-6; text-fig. 4.
Age. LO: late Campanian.

Remarks. The Cretaceous forms found in the present study tend to have slightly more pronounced ornamentation than that of the Jurassic holotype of Atopodinium haromense (Thomas \& Cox 1988, plate 1, figs 1, 2).

\section{Genus Axiodinium Williams, Damassa, Fensome \&} Guerstein in Fensome et al. 2009

Type. Williams \& Downie 1966b, plate 18, fig. 1, as

Wetzeliella articulata; now Axiodinium prearticulatum.

2009 Axiodinium Williams, Damassa, Fensome \& Guerstein in Fensome et al., p. 16.

Remarks. Both Axiodinium and Apectodinium are wetzelielloidean genera with an equiepeliform archaeopyle (Williams et al. 2015), but Axiodinium is clearly cavate and Apectodinium does not have a clear or consistent separation of the endophragm and periphragm.

\section{Axiodinium augustum (Harland 1979b) Williams et al. 2015}

(Plate 2, figs 14, 15)

1979b Wetzeliella (Apectodinium) augusta Harland, p. 63, plate 2, figs 13-15.

1981 Apectodinium augustum (Harland) - Lentin \& Williams, p. 14.

2015 Axiodinium augustum (Harland) - Williams et al., p. 301.

Age. LO: basal Ypresian.

Genus Batiacasphaera Drugg 1970

Type. Drugg 1970, fig. 6A-B, as Batiacasphaera compta.

1970 Batiacasphaera Drugg, p. 813.

Remarks. We adhere to the synopsis presented in Fensome et al. (2009, p. 17), which specifies that the apical archaeopyle has an outline lacking or with weakly developed accessory sutures between precingular plates and a free operculum.

Batiacasphaera micropapillata Stover 1977

(Plate 2, fig. 16)

1977 Batiacasphaera micropapillata Stover, p. 73, plate 1 , figs 7,8 . 
Age. LO (not confirmed in present study) Gelasian on Scotian Margin (Fensome et al. 2009). Not plotted.

Remarks. This is a species of Batiacasphaera with a granulate to microreticulate ornamentation.

\section{Genus Batioladinium Brideaux 1975}

Type. Alberti 1961, plate 5, fig. 2, as Broomea jaegeri.

1975 Batioladinium Brideaux, p. 124.

1975 Necrobroomea Wiggins, p. 111.

Synopsis. An elongate pareodiniacean cyst, drawn out into one apical and two generally equal antapical horns. Acavate. Wall consisting of autophragm. Archaeopyle apical, with formula $\mathrm{A}_{\left(1-2^{\prime}\right)}$, formed from the loss of the two apical plates.

Remarks. The synopsis is based on the interpretation of the archaeopyle presented in Wharton (1988, text-fig. 4.13) and Fensome et al. (1993, p. 77, 78). The antapical horns, though equal on a single specimen, are of variable length from specimen to specimen.

\section{Batioladinium jaegeri (Alberti 1961) Brideaux 1975}

(Plate 2, fig. 17)

1961 Broomea jaergeri Alberti, p. 26, plate 5, figs 1-7.

1975 Batioladinium jaegeri (Alberti) - Brideaux, p. 1240.

1975 Necrobroomea jaegeri (Alberti) - Wiggins, p. 111.

1980 Imbatodinium jaegeri (Alberti) - Dörhöfer \& Davies, p. 37.

1981 Pseudoceratium hansgochtii Lentin \& Williams, p. 236.

Age. LO: Campanian.

Remarks. Most records of this species are from the Early Cretaceous, but it appears to have an extended range up to the Campanian in western and northern North America (e.g. Harker et al. 1990).

\section{Genus Callaiosphaeridium Davey \& Williams 1966a}

Type. Deflandre \& Courteville 1939, plate 4, fig. 1, as Hystrichosphaeridium asymmetricum. 1966a Callaiosphaeridium Davey \& Williams, p. 103. 1967 Hexasphaera Clarke \& Verdier, p. 42; name illegitimate.

Remarks. Callaiosphaeridium is a chorate gonyaulacacean genus that has large, tubular mesotabular or gonal processes on the cingulum and may have slender gonal processes elsewhere. The archaeopyle is epicystal, with the formula $\left(\mathrm{A}_{1-4^{\prime}}, \mathrm{P}_{1-6^{\prime}}\right)$ and a simple operculum.

\section{Callaiosphaeridium asymmetricum (Deflandre \& Courteville 1939) Davey \& Williams 1966a}

(Plate 2, fig. 18)

1939 Hystrichosphaeridium asymmetricum Deflandre \& Courteville, p. 100, 101, plate 4, figs 1, 2.

1966a Callaiosphaeridium asymmetricum (Deflandre \& Courteville) - Davey \& Williams, p. 104.

1967 Hexasphaera asymmetrica (Deflandre \& Courteville) - Clarke \& Verdier, p. 43; combination illegitimate.

Age. LO: Campanian.

Genus Cannosphaeropsis Wetzel 1933a

Type. Wetzel 1933a, plate 3, fig. 9a, b, as Cannosphaeropsis utinensis.

1932 Cannosphaeropsis Wetzel, p. 136; name not validly published.

1933a Cannosphaeropsis Wetzel, p. 6.

Synopsis. Chorate gonyaulacacean (gonyaulacoidean) cysts with a subspherical to ellipsoidal central body. Tabulation on the central body delineated by gonal processes, which can be restricted to the cingular plates, and sometimes also intergonal processes, which distally are united by trabecula that also reflect the tabulation. The gonal processes are trifurcate distally, the intergonal processes are bifurcate distally. Archaeopyle precingular, with formula $\mathrm{P}_{3^{\prime},}$; operculum free.

Cannosphaeropsis passio de Verteuil \& Norris 1996 (Plate 3, fig. 5)

1996 Cannosphaeropsis passio de Verteuil \& Norris, p. $130,132,134,136$, plate 7 , figs $1-8$; plate 8, figs 1-6; plate 17, figs 1, 3-5; text-fig. 33 .

Age. LO: Serravallian (based on Piasecki 2003). 
Remarks. De Verteuil \& Norris (1996) described Cannosphaeropsis passio as having cingular processes only, even though the trabecula delineate the complete tabulation.

\section{Genus Cerebrocysta Bujak in Bujak et al. 1980}

Type. Bujak et al. 1980, plate 13, figs 4-5, as Cerebrocysta bartonensis.

\section{Cerebrocysta Bujak in Bujak et al., p. 42.}

Remarks. The synopsis for Cerebrocysta provided by Fensome et al. (2009, p. 18) covers all the salient details of the morphology of this genus. These authors also noted that it is difficult to separate Cerebrocysta from Pyxidinopsis. The only distinctions are in the possible variability in the number of precingular plates lost in archaeopyle formation in Cerebrocysta and perhaps different wall structures. Regardless, we follow Fensome et al. (2009) in assigning Cenozoic taxa with the general morphology of Cerebrocysta and Pyxidinopsis to Cerebrocysta.

\section{Cerebrocysta bartonensis Bujak in Bujak et al. 1980} (Plate 2, figs 19, 20)

1980 Cerebrocysta bartonensis Bujak in Bujak et al., p. 42, plate 13 , figs $4-7$.

Age. LO: Bartonian.

\section{Cerebrocysta magna Bujak 1994}

(Plate 3, fig. 6)

1994 Cerebrocysta magna Bujak, p. 121, plate 2, figs 10,11 .

Age. LO: Lutetian.

\section{Genus Cerodinium Vozzhennikova 1963}

Type. Vozzhennikova 1963, text-fig. 9, as Cerodinium sibiricum.

1963 Cerodinium Vozzhennikova, p. 181.

1963 Ceratiopsis Vozzhennikova, p. 181; name illegitimate.

Remarks. Fensome et al. (2009, p. 18) noted that Cerodinium is characterised by having an isodeltaform to isothetaform $2 \mathrm{a}$ plate, a free perioperculum and a symmetrical antapex. The endoarchaeopyle may involve all three anterior intercalary plates. At present it does not seem practicable to separate into distinct species forms that lose the 2a plate only from those that lose the $1 \mathrm{a}, 2 \mathrm{a}$ and 3 a plates individually from the endocyst. However, such a separation seems to have some stratigraphic value as forms occurring in younger rocks all seem to lose the 2a plate only; earlier forms may lose all three anterior intercalaries.

\section{Cerodinium diebelii (Alberti 1959) Lentin \& Williams 1987}

(Plate 3, figs 1-4)

1959 Deflandrea diebelii Alberti, p. 99, 100, plate 9, figs 18-21.

1967 Ceratiopsis diebelii (Alberti) - Vozzhennikova, p. 159; combination illegitimate.

1987 Cerodinium diebelii (Alberti) - Lentin \& Williams, p. 114.

Age. LO: latest Danian.

\section{Cerodinium glabrum (Gocht 1969) Fensome et al. 2009}

(Plate 3, figs 7, 8)

1969 Deflandrea speciosa forma glabra Gocht, p. 10, text-fig. 3.

1973 Deflandrea speciosa subsp. glabra (Gocht) Lentin \& Williams, p. 45.

1977a Ceratiopsis speciosa subsp. glabra (Gocht) Lentin \& Williams, p. 21 (combination illegitimate).

1987 Cerodinium speciosum subsp. glabrum (Gocht) - Lentin \& Williams, p. 115.

2009 Cerodinium glabrum (Gocht) - Fensome et al, p. 19.

Age. LO: latest Thanetian (Late Paleocene).

\section{Cerodinium kangiliense Nøhr-Hansen \&} Heilmann-Clausen 2001

(Plate 3, figs 9, 10)

2001 Nøhr-Hansen \& Heilmann-Clausen, p. 158, 160, 162-164, fig. 4, nos 1-9, fig. 5, nos 1-9.

Age. LO: Selandian.

\section{Cerodinium speciosum (Alberti 1959) Lentin \& Williams 1987}

(Plate 3, fig. 13) 
1959 Deflandrea speciosa Alberti, p. 97, plate 9, figs 12, 13.

1977a Ceratiopsis speciosa (Alberti) - Lentin \& Williams, p. 21; combination illegitimate.

1987 Cerodinium speciosum (Alberti) - Lentin \&Williams, p. 115.

Age. LO: latest Thanetian.

\section{Cerodinium striatum (Drugg 1967) Lentin \& Williams 1987}

(Plate 3, figs 11, 12)

1967 Deflandrea striata Drugg, p. 18, plate 2, figs 13, 14 .

1977a Ceratiopsis striata (Drugg) - Lentin \& Williams, p. 21; combination illegitimate.

1987 Cerodinium striatum (Drugg) - Lentin \& Williams, p. 115.

Age. LO Thanetian. Not plotted.

Remarks. Cerodinium striatum has a distinct development of more or less parallel folds. The folds should not be confused with the plications of Cerodinium diebelii (which is distinctly elongate) or the linearly aligned granules or denticles in Cerodinium speciosum.

\section{Genus Charlesdowniea Lentin \& Vozzhennikova 1989 emend. Williams et al. 2015}

Type. Williams \& Downie 1966b, plate 18, fig. 8, textfig. 47, as Wetzeliella coleothrypta, and Bujak et al. 1980, plate 12, figs 7, 8, as Kisselevia coleothrypta.

1989 Charlesdowniea Lentin \& Vozzhennikova, p. 225, 227.

Remarks. The emended diagnosis of Williams et al. (2015) is followed; this emphasises the archaeopyle type and the nature of the pericystal ornamentation. The archaeopyle of Charlesdowniea is equiepeliform and the processes are intratabular and sometimes also penitabular. Distally, the processes on individual plates are united by membranes.

\section{Charlesdowniea coleothrypta (Williams \& Downie 1966b) Lentin \& Vozzhennikova 1989}

(Plate 4, fig. 9)

1966b Wetzeliella coleothrypta Williams \& Downie, p. 185,186 , plate 18 , figs 8 , 9; text-fig. 47 .
1976 Kisselevia coleothrypta (Williams \& Downie) Lentin \& Williams, p. 136.

1989 Charlesdowniea coleothrypta (Williams \&

Downie) - Lentin \& Vozzhennikova, p. 225.

Age. LO: Ypresian. Not plotted.

Remarks. In the Labrador Margin samples, Charlesdowniea coleothrypta has its LO just below that of Scalenodinium scalenum, but is not common.

\section{Genus Chatangiella Vozzhennikova 1967 emend. nov. \\ Type. Vozzhennikova 1967, plate 56, fig. 1; plate 57, fig. 1, as Chatangiella niiga. \\ 1967 Chatangiella Vozzhennikova, p. 128, 129. \\ 1967 Australiella Vozzhennikova, p. 129, 130. \\ 1967 Cooksoniella Vozzhennikova, p. 183, 184.}

Emended description. Peridiniacean (deflandreoid) cysts that are proximate, dorsoventrally compressed and peridinioid in outline, with epicystal 'shoulders' and asymmetrical antapex, the left side being larger. Circumcavate to, generally, bicavate. Surface generally atabulate to weakly paratabulate, but cingulum clearly reflected by ridges, commonly serrated, reflecting the positions of pre- and postcingular plates. Periarchaeopyle intercalary, with formula $\mathrm{I}_{2 \mathrm{a}}$, operculum free or attached; plate $2 \mathrm{a}$ is lati- to iso-omegaform hexa; endoarchaeopyle with formula $\mathrm{I}_{2 \mathrm{a}}$ or $\mathrm{I}_{1 \mathrm{a}+2 \mathrm{a}+3 \mathrm{a}}$.

Remarks. Fensome et al. (2009, p. 19) provided a synopsis for Chatangiella that encompasses all its salient morphologic features. As part of their synopsis, these authors stated: "Periarchaeopyle intercalary, with formula $\mathrm{I}_{2 \mathrm{a}}$, operculum free or attached; plate $2 \mathrm{a}$ is isodeltaform to (typically) iso-omegaform hexa; endoarchaeopyle with

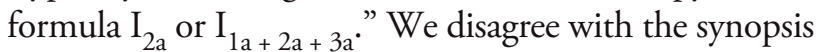
of Fensome et al. (2009) in two important respects. Firstly, only taxa with omegaform 2a plates should be included in Chatangiella; and, secondly, taxa with $2 \mathrm{a}$ plates that are lati-omegaform must be included since the type of Chatangiella (Vozzhennikova 1967, plate 56, fig. 1; plate 57, fig. 1) has such an archaeopyle. Thus it is proposed here that a characteristic feature of Chatangiella be the possession of a lati- or iso-omegaform hexa $2 \mathrm{a}$ plate.

In their emendation of Chatangiella, Lentin \& Williams (1976, p. 51, 52) emphasised the omegaform shape of the pericystal $2 \mathrm{a}$ plate and its common attachment 
posteriorly. Unfortunately, the critical shape and relationship of this plate have been overlooked in many subsequent papers. To correct this concern, the omegaform shape of the operculum is re-emphasised in the emended description above. Although epicystal shoulders, a distinctive characteristic of this genus, appear to almost always be related to the presence of an omegaform periarchaeopyle, which feature came first is open to debate.

As noted under Alterbidinium, the morphological differences used to separate the deflandreoid genera are in large part unsatisfactory. This criticism applies to Chatangiella: to bring stability to the genus, we propose that any peridiniacean forms with a partite cingulum that do not have an omegaform periarchaeopyle should be re-assigned.

\section{Chatangiella decorosa (McIntyre 1975) Lentin \& Williams 1976}

1975 Deflandrea decorosa McIntyre, p. 63, 64, plate 2 , figs 1-4.

1976 Chatangiella decorosa (McIntyre) - Lentin \& Williams, p. 54.

Age. LO: early Campanian.

Remarks. McIntyre (1975, p. 64) noted that Chatangiella decorosa differs from Chatangiella ditissima in being larger. The size of Chatangiella ditissima overlaps that of Chatangiella tripartita. Chatangiella decorosa also has more pustules than Chatangiella ditissima.

\section{Chatangiella madura Lentin \& Williams 1976}

(Plate 3, figs 14, 15)

1970b Deflandrea manumii Cookson \& Eisenack, p. 141, 142, plate 11, figs 10, 11 .

1976 Chatangiella manumii (Cookson \& Eisenack) - Lentin \& Williams, p. 54; name illegitimate.

1976 Chatangiella madura (Cookson \& Eisenack) Lentin \& Williams, p. 54.

Age. LO: Campanian.

\section{Chatangiella tripartita (Cookson \& Eisenack 1960a) Lentin \& Williams 1976}

(Plate 3, figs 16, 20)

1960a Deflandrea tripartita Cookson \& Eisenack, p. 2, 3, plate 1, fig. 10 .
1967 Australiella tripartita (Cookson \& Eisenack) Vozzhennikova, p. 134, 135.

1976 Chatangiella tripartita (Cookson \& Eisenack) - Lentin \& Williams, p. 55.

Age. LO: Campanian (Late Cretaceous). Not plotted.

Remarks. There is considerable confusion concerning the morphology of Chatangiella tripartita and the related form Chatangiella victoriensis. Both are surprisingly large. According to Cookson \& Eisenack (1960a, p. 3), the pericyst of Chatangiella tripartita ranges from 100 to $120 \mu \mathrm{m}$ in length and 59 to $71 \mu \mathrm{m}$ in width. Cookson \& Manum (1964) stated that in Chatangiella victoriensis, the pericyst was 76 to $116 \mu \mathrm{m}$ in length and 49-73 $\mu \mathrm{m}$ in width. Comparison of the sizes of the above two species with one of the higher latitude (Arctic) species of Chatangiella, Chatangiella ditissima, shows that there is some overlap, especially in width. McIntyre (1975, p. 63) noted that the pericyst in Chatangiella ditissima could be 115-150 $\mu \mathrm{m}$ long and 60-90 $\mu \mathrm{m}$ wide. The similar but even larger, higher latitude species Chatangiella decorosa has a pericyst that can be 130-175 $\mu \mathrm{m}$ long and $80-110 \mu \mathrm{m}$ wide.

Our conclusion from comparison of several Chatangiella species is that size is not a reliable characteristic when separating species. But size has some significance: for example specimens of Chatangiella found on the Grand Banks of Newfoundland are generally much smaller than those from the high Arctic. Gigantism is a common feature of life in higher latitudes, so it is no surprise to find it among dinoflagellates.

Differences in the expression of the cingulum and the surface ornamentation of the pericyst are perhaps more diagnostic. Cookson \& Manum (1964, p. 521, 522) noted that the cingulum of the holotype of Chatangiella tripartita is denoted by two pairs of ill-defined short, offset, low parallel ridges on the ventral surface and a fold-like line on the dorsal surface. The ridges are not serrate or denticulate, a feature of many specimens placed in Chatangiella tripartita. Regarding the cingulum of Chatangiella victoriensis, Cookson \& Manum (1964) stated that it "is bordered by conspicuous ridges or by linearly arranged wart-like thickenings of varying size and shape". McIntyre (1975, p. 62, 63) described Chatangiella ditissima as having a cingulum delineated by "discontinuous ridges consisting of rows of pustules that may join to form narrow grooves". That author recognised seven and five ridges on the anterior and posterior margins respectively of the cingulum, which represent the difference in number of plates between the pre- and 
postcingular series. These two series of plates can also have penitabular pustules mirroring the plate outlines.

Cookson \& Manum (1964, p. 522) gave a thickness of $1.0-1.7 \mu \mathrm{m}$ for the periphragm (as the thecal wall) of Chatangiella victoriensis and noted that it is "ornamented with fairly evenly scattered rod-like projections $c$. $0.5-1.5 \mu \mathrm{m}$ long; in surface view the rods appear as dots usually between 0.5 and $1.0 \mu \mathrm{m}$ in diameter but a few smaller and larger ones are usually present". In Chatangiella tripartita, the periphragm is finely granular. McIntyre (1975) described the periphragm of Chatangiella ditissima as smooth, except for the pustules delineating the tabulation and occasional pits.

What is the conclusion to be drawn from the above and from our observations on the specimens from the offshore wells? The most compelling is the extreme variability in the size of the taxa and the degree of expressions of tabulation. In this paper, all the 'smaller' forms are assigned to Chatangiella tripartita if they lack pustules other than on the cingulum. We would like to include those smaller forms with pustules defining the pre- and postcingular plates in a new species but do not have enough specimens to do that here.

\section{Genus Chiropteridium Gocht 1960 emend. nov.}

Type. Gocht 1960, plate 17, fig. 1, as Chiropteridium lobospinosum.

1959 Galea Maier, p. 305; name illegitimate. 1960 Chiropteridium Gocht, p. 221.

Emended diagnosis. Areoligeracean cysts that are proximochorate to chorate, with subrounded to lenticular central body that may be asymmetrical antapically. Cavate or acavate; if cavate, with cavation mainly restricted to scalloped marginal wings; when acavate there may be marginal wings and/or processes. Midventral and mid-dorsal areas devoid of processes or having processes of a reduced size. Surface atabulate or with intratabular processes. Archaeopyle apical, with formula $A_{\left(1-4^{\prime}\right)}$ and free operculum; sulcal notch offset to the left.

Remarks. Chiropteridium has not been emended previously. However, Stover \& Evitt (1978) provided a synopsis and modified description and Fensome et al. (2009, p. 21) gave a synopsis. In their synopsis of Chiropteridium, Stover \& Evitt (1978, p. 27) stated: "Cysts skolochorate, body lenticular; processes isolated or connected proximally and absent or greatly reduced in size and number on ventral surface; archaeopyle apical, Type tA; parasulcal notch offset." In their modified description, the same authors noted that processes could be isolated or partly connected in longitudinal rows, with the connections being proximal. Also they stated that processes are absent or reduced in size and numbers ventrally. Fensome et al. (2009, p. 21) were more specific in providing the following synopsis for Chiropteridium: "Areoligeracean cysts that are proximochorate to chorate, with lenticular central body that may be asymmetrical antapically. Cavate or acavate; if cavate, with cavation mainly restricted marginally to 'wings' and scalloped; if acavate, marginate wings formed from longitudinal crests or from longitudinally taeniate processes. Surface atabulate. Archaeopyle apical, with formula $A_{\left(1-4^{\prime}\right)}$, operculum free; sulcal notch offset to the left."

Fensome et al. (2009, p. 21) stated that "Chiropteridium is characterised by lateral extensions or 'wings' that may be cavate; these wings are typically scalloped to varying degrees or formed by taeniate processes. In Membranophoridium, processes are absent and the 'wings' are continuous pericoelar sacs." Although correct for species included to date in Chiropteridium, forms are recorded here that possess only processes that are not connected proximally or along their length and which denote the tabulation. These are accommodated in the above emended diagnosis for Chiropteridium.

\section{Chiropteridium galea (Maier 1959) Sarjeant 1983}

(Plate 3, figs 17-19)

1959 Galea galea Maier, p. 306, plate 29, fig. 4; text-fig. 2.

1959 Galea levis Maier, p. 308, plate 30, figs 1, 2.

1959 Galea mespilana Maier, p. 306, 307, plate 29, figs 5, 6.

1960 Chiropteridium dispersum Gocht, p. 227, plate 18, figs 1-16; text-figs 16-27.

1961 Membranophoridium multispinatum Gerlach, p. 203, 204, plate 29, fig. 5 .

1961 Membranophoridium partispinatum Gerlach, p. 201, plate 29, fig. 6 .

1963 Chiropteridium partispinatum (Gerlach) Brosius, p. 48.

1964 Baltisphaeridium leve (Maier) - Sarjeant, p. 176.

1964 Baltisphaeridium mespilanum (Maier) Sarjeant, p. 176.

1969 Cleistosphaeridium leve (Maier) - Davey et al., p. 16.

1973 Chiropteridium mespilanum (Maier) - Lentin \& Williams, p. 26. 
1975 Hystrichosphaeridium mespilanum (Maier) Eisenack \& Kjellström, p. 233, 234.

1983 Chiropteridium galea (Maier) - Sarjeant, p. 108.

Age. LO: Chattian.

\section{Chiropteridium gilbertii sp. nov.}

(Plate 4, figs 1-4)

Holotype. Plate 4, fig. 4, from a cuttings sample at 1600-1610 m in Gilbert F-53, GSC type collection no.137976, sample P39466, slide 01, co-ordinates 17.4 $\times 106.0$, England Finder R36/3. Overall length $83 \mu \mathrm{m}$, width $87 \mu \mathrm{m}$; central body, length $57 \mu \mathrm{m}$, width 52 $\mu \mathrm{m}$; maximum length of processes $20 \mu \mathrm{m}$, width varies from less than 1 to $10 \mu \mathrm{m}$. The age determined for the sample from which the holotype was recovered is basal Bartonian.

Etymology. The epithet is derived from the name of the Gilbert F-53 offshore exploration well, in which the species is abundant.

Diagnosis. A species of Chiropteridium in which the processes or process complexes delineate the tabulation and there are no interconnections between processes representing adjacent plates.

Description. The processes delineate the tabulation, though none are interconnected. Processes on the midventral and mid-dorsal surfaces are reduced in width or absent: this is especially true of the $3^{\prime \prime}$ process that, if present, is very slender. Commonly, processes are basally trumpet-shaped, then tubular or parallel-sided. Processes are also of variable size depending on which plate series they are reflecting, with cingular processes being invariably slender, precingular processes broader, and postcingular processes being broader still, and the antapical process being broadest of all. Many of the processes are perforate.

Size. Overall maximum diameter $87 \mu \mathrm{m}$; maximum diameter of central body $57 \mu \mathrm{m}$; maximum length of processes $25 \mu \mathrm{m}$, maximum width $17 \mu \mathrm{m}$; seven specimens measured.

Age. LO: Bartonian.

Remarks. In Chiropteridium gilbertii, the central body, which is granulate, commonly has a prominent antapi- cal protuberance. All of the processes, which are intratabular, have a circular cross-section proximally and distally are closed and commonly branch into short bifurcations or aculeae. Proximally, the processes tend to be conical then become tubular about halfway along their length before flaring distally. The processes are often fibrous and/or perforate, especially the antapical process, which sometimes subdivides to form a process complex. Recognition of the antapical process, if the archaeopyle is not obvious, is facilitated by the extreme width and the perforations, which may form arches in the process wall. Cingular processes are invariably slender, some less than $1 \mu \mathrm{m}$ wide, rarely exceed four in number, and are restricted to the ambital region of the central body. Apical processes show variation in width on different specimens. Precingular processes are always narrower than the postcingular processes. Although the sulcal notch is offset, this is not always obvious.

Chiropteridium gilbertii differs from Chiropteridium galea in having processes or process complexes that are restricted to individual plates. Licracysta semicirculata has processes that are restricted to the ambitus and tend to form arcuate complexes. The processes of Chiropteridium gilbertii vary in size according to the plate they represent, and are often fibrous and/or perforate. Chiropteridium conispinum also has membranous processes, but these are restricted to the dorsal surface, with two linear membranes running apically-antapically on the ventral surface.

\section{Genus Chlamydophorella Cookson \& Eisenack 1958}

Type. Cookson \& Eisenack 1958, plate 11, fig. 1, as Chlamydophorella nyei.

\section{Chlamydophorella Cookson \& Eisenack, p. 56.}

Remarks. As Fensome et al. (2009, p. 21) noted in their synopsis for Chlamydophorella, the genus is characterised by being proximate, holocavate, with short, solid processes forming buttresses between the autophragm and ectophragm, an apical horn formed from the ectophragm, and an apical archaeopyle. The tabulation is gonyaulacacean, but whether it shows neutral or dextral torsion is not known. Sepispinula differs from Chlamydophorella in lacking an ectophragm.

Chlamydophorella nyei Cookson \& Eisenack 1958 (Plate 4, fig. 5) 
1958 Chlamydophorella nyei Cookson \& Eisenack, p. 56, plate 11, figs 1-3.

1970b Chlamydophorella apiculata Cookson \& Eisenack, p. 150, 151, plate 13, fig. 3.

1970b Chlamydophorella lagena Cookson \& Eisenack, p. 151, plate 13, fig. 4.

Age. LO: Coniacian (Late Cretaceous).

\section{Chlamydophorella cf. nyei Cookson \& Eisenack 1958}

(Plate 4, figs 6-8)

Age. LO : Campanian. Not plotted.

Remarks. This form includes specimens similar to Chlamydophorella nyei but which lack an evident apical horn.

\section{Genus Chytroeisphaeridia (Sarjeant 1962) Downie \& Sarjeant 1965}

Type. Sarjeant 1962, plate 70, fig. 13, as Leiosphaeridia subgenus Chytroeisphaeridia chytroeides.

1962 Leiosphaeridia subgenus Chytroeisphaeridia Sarjeant, p. 492.

1965 Chytroeisphaeridia Downie \& Sarjeant, p. 102.

Chytroeisphaeridia hadra sp. nov.

(Plate 4, figs 17, 18)

Holotype. Plate 4, fig. 18 from a cuttings sample at 3120-3140 m in Roberval K-92, GSC type collection no. 137902, sample P17728, slide 01 , co-ordinates $19.5 \times 109.8$, England Finder U40/1. Overall length $79 \mu \mathrm{m}$, width $81 \mu \mathrm{m}$; wall thickness $5 \mu \mathrm{m}$, archaeopyle length $37 \mu \mathrm{m}$, width $33 \mu \mathrm{m}$. The age determined for the sample from which the holotype was recovered is Late Cretaceous (the specimen is caved).

Etymology. The epithet is from the Greek hadros meaning well-developed, bulky, stout, strong, great, in reference to the thick, sturdy wall.

Diagnosis. A species of Chytroeisphaeridia with a thick wall that has a subdued rugulate, sometimes lightly striated surface. The archaeopyle is large, apparently resulting from the loss of the 3 "' plate only.

Size. Overall length $69-82 \mu \mathrm{m}$; width $64-81 \mu \mathrm{m}$. Six specimens measured.
Age. LO: Bartonian.

Remarks. Some specimens of Chytroeisphaeridia hadra have parallel striations on the wall but these are irregular and discontinuous. The archaeopyle is large, suggesting that more than a single plate may be involved.

\section{Genus Cleistosphaeridium Davey et al. 1966}

Type. Davey et al. 1966, plate 10, fig. 7, as Cleistosphaeridium diversispinosum.

\section{Cleistosphaeridium Davey et al., p. 166.}

Remarks. We concur with the retention and emendation of Cleistosphaeridium as proposed by Eaton et al. (2001, p. 176, 177) and the synopsis provided by Fensome et al. (2009, p. 22). Following Fensome et al. (2007, p. 408), Cleistosphaeridium is considered to be areoligeracean because of the asymmetry in some specimens of the antapex and sulcal notch, and also because it forms a morphological plexus with other areoligeracean genera, including Glaphyrocysta, Enneadocysta, Licracysta and Cooksonidium. We include in the genus species in which adjacent processes are medially and distally interconnected.

\section{Cleistosphaeridium diversispinosum Davey et al. 1966}

(Plate 4, figs 19, 20)

1966 Cleistosphaeridium diversispinosum Davey et al., p. 167, plate 10, fig. 7 .

1993 Systematophora diversispinosa (Davey et al.) Islam, p. 88.

Age. LO: Serravallian.

Remarks. Following Fensome et al. (2009, p. 22), Cleistosphaeridium diversispinosum and Cleistosphaeridium ancyreum are not considered synonyms.

\section{Cleistosphaeridium elegantulum sp. nov.}

(Plate 4, figs 10-12)

Holotype. Plate 4, fig. 12, from a cuttings sample at 2286.03 to $2295.17 \mathrm{~m}$ in Karlsefni A-13, GSC type collection no. 138033, sample P39600, slide 01, co-ordinates 17.9 × 101.7, England Finder S44.2. Central body maximum diameter $50 \mu \mathrm{m}$, maximum length of processes about $25 \mu \mathrm{m}$. The age determined for the sample from which the holotype was recovered is Lutetian-Bartonian. 
Etymology. From the Latin elegantulus (very fine), in reference to the narrow, long processes.

Diagnosis. A species of Cleistosphaeridium with numerous long, fine, flexible, unconnected processes, some to many of which are dolabrate distally. The length of many of the processes equals about one half of the central body diameter. Proximal ridges are absent to weakly developed.

Size. Central body diameter 30-57 $\mu \mathrm{m}$; maximum length of processes up to half maximum diameter of central body; three specimens measured.

Age. LO: Lutetian-Bartonian. Not plotted.

Remarks. This species differs from other species of Cleistosphaeridium in its long, fine, flexible processes.

\section{Cleistosphaeridium palmatum sp. nov.}

(Plate 4, figs 13-16)

Holotype. Plate 4, figs 13, 14 from a cuttings sample at 2450-2460 m in Roberval K-92: GSC type collection no. 137897, sample P17706, slide 01, co-ordinates 6.9 $\times$ 100.6, England Finder G30/0-2. Maximum overall diameter $87 \mu \mathrm{m}$, maximum diameter of central body 50 $\mu \mathrm{m}$, maximum length of processes $25 \mu \mathrm{m}$. The age determined for the sample from which the holotype was recovered is early Ypresian.

Etymology. The epithet is from the Latin palmatus, meaning marked or shaped like the palm of the hand, in reference to the shape of the distal terminations of the processes.

Diagnosis. A species of Cleistosphaeridium in which the solid processes are of irregular width, varying from 1-7 $\mu \mathrm{m}$ and distally slender to splayed, with some adjacent processes interconnected distally, commonly so that they form arches.

Description. The processes are of irregular width, distally slender to splayed, with some adjacent processes interconnected distally. They are predominantly dolobrate, but some are bifid. The wall of the central body is generally less than $1 \mu \mathrm{m}$ thick. Archaeopyle apical, with formula $A_{\left(1-4^{\prime}\right)}$, operculum attached or free. Other aspects of the tabulation cannot be determined, as specimens possess more than one process per plate, sometimes in complexes. Where present, the complexes appear to occur on the precingular, postcingular and antapical plates.

Size. Maximum diameter of central body $48 \mu \mathrm{m}$, length of processes $10-25 \mu \mathrm{m}$, four specimens measured.

Age. LO: late Ypresian.

Remarks. The processes of specimens belonging to this species show similarities to those found in Adnatosphaeridium, Enneadocysta, Licracysta and other species of Cleistosphaeridium. Although the distal branches of processes can sometimes be interconnected, the general absence of trabecula uniting processes precludes assignment of the species to Adnatosphaeridium. Cleistosphaeridium palmatum differs from species of Enneadocysta because the number of processes per plate (where discernible as being related to tabulation) invariably exceeds one, and distally processes are dolobrate rather than licrate or clypeate. Moreover, the antapex of Cleistosphaeridium palmatum is not characterised by two processes (see Fensome et al. 2007, p. 394). Cleistosphaeridium diversispinosum differs in not having branched processes in which the branches often meet along their length or distally and in not having spatulate endings. Specimens of the species Cleistosphaeridium polypetellum are slender and are not spatulate or branched distally; species of Licracysta have proximal and ventral surfaces on which processes are absent or reduced.

\section{Cleistosphaeridium polypetellum (Islam 1983b) Stover \& Williams 1995}

(Plate 5, figs 1, 2)

1983b Areosphaeridium polypetellum Islam, p. 82, 84, plate 2, figs 1-6.

1995 Cleistosphaeridium polypetellum (Islam) Stover \& Williams, p. 102.

Age. LO: Ypresian.

Remarks. Some connections occur between adjacent processes, differentiating this species from Cleistosphaeridium diversispinosum and Cleistosphaeridium ancyreum. Processes in Cleistosphaeridium polypetellum are less variable and the species lacks the thick processes of Cleistosphaeridium palmatum. Distally, most processes of Cleistosphaeridium polypetellum are strongly dolabrate and sometimes licrate. However, a few simple bifid processes occur. 


\section{Genus Cordosphaeridium Eisenack 1963a}

Type. Klumpp 1953, plate 18, figs 1, 2, as Hystricho-

sphaeridium inodes.

1963a Cordosphaeridium Eisenack, p. 261.

1981 Tityrosphaeridium Sarjeant, p. 120.

Remarks. We concur with the synopsis for Cordosphaeridium provided by Fensome et al. (2009, p. 22). The characteristic features of the genus are the spheroidal central body, the precingular $\left(\mathrm{P}_{3}{ }^{\prime \prime}\right)$ archaeopyle and the fibrous wall and processes. The processes, which are commonly cylindrical and restricted to one per plate, are generally of approximately equal length but can show considerable variation in width.

\section{Cordosphaeridium cantharellus (Brosius 1963)} Gocht 1969

(Plate 5, fig. 7)

1963 Hystrichosphaeridium cantharellus Brosius, p. 40, 41, plate 6, fig. 1; text-fig. 2, nos 11a-c.

1969 Cordosphaeridium cantharellus (Brosius) Gocht, p. 45.

1981 Tityrosphaeridium cantharellus (Brosius) Sarjeant, p. 120.

Age. LO: Burdigalian.

Remarks. As in the holotype, the process width in the Labrador Margin specimens of Cordosphaeridium cantharellus shows considerable variation. The species was retained in Cordosphaeridium by Edwards (2001, p. G19).

\section{Cordosphaeridium delimurum Fensome et al. 2009}

(Plate 5, figs 3, 4)

2009

$$
\begin{aligned}
& \text { Cordosphaeridium delimurum Fensome et al., } \\
& \text { p. 23, plate 2, figs l-q. }
\end{aligned}
$$

Age. LO: early Lutetian. Not plotted.

Remarks. As its name implies, Cordosphaeridium delimurum differs from Cordosphaeridium inodes and Cordosphaeridium gracile in having a much thinner central body wall. Unlike Cordosphaeridium fibrospinosum, Cordosphaeridium delimurum has solid rather than perforate process walls.

\section{Cordosphaeridium fibrospinosum Davey \&} Williams 1966a

(Plate 5, figs 5, 6)

1966a Cordosphaeridium fibrospinosum Davey \& Williams, p. 86, plate 5, fig. 5.

1966a Cordosphaeridium exilimurum Davey \& Williams, p. 87, 88, plate 11, fig. 2.

1970 Achomosphaera valianta Sah et al., p. 145, plate 1, figs 8, 9.

1978 Cordosphaeridium valiantum (Sah et al.) Stover \& Evitt, p. 147.

1981 Hystrichosphaerina? exilimura (Davey \&Williams) - Sarjeant, p. 122.

1981 Emmetrocysta? fibrospinosa (Davey \& Williams) - Sarjeant, p. 123.

1986 Tityrosphaeridium? exilimurum (Davey \& Williams) - Jain \& Garg, p. 120.

1986 Tityrosphaeridium? fibrospinosum (Davey \& Williams) - Jain \& Garg, p. 121.

Age. LO: late Rupelian. Not plotted.

Remarks. As noted above, Cordosphaeridium fibrospinosum has processes with fibrous, perforate walls. We agree with Fensome et al. (2009) that Cordosphaeridium exilimurum and its long-recognised synonym Achomosphaera valianta cannot be meaningfully differentiated from Cordosphaeridium fibrospinosum. Although this species has an Oligocene LO, at least in offshore eastern Canada, it tends to be most common in the Paleocene.

Cordosphaeridium funiculatum Morgenroth 1966a (Plate 5, fig. 8)

1966a Cordosphaeridium funiculatum Morgenroth, p. 22, 23, plate 6, figs 2-3.

1981 Tityrosphaeridium funiculatum (Morgenroth) - Sarjeant, p. 121.

Age. LO: Priabonian.

\section{Cordosphaeridium gracile (Eisenack 1954) Davey \& Williams 1966a}

(Plate 5, fig. 9)

1954 Hystrichosphaeridium inodes subsp. gracile Eisenack, p. 66, plate 8, fig. 17; plate 10, figs 3-8; plate 12, figs 7, 21.

1963a Cordosphaeridium inodes subsp. gracile (Eisenack) - Eisenack, p. 261. 
1966a Cordosphaeridium gracile (Eisenack) - Davey \& Williams, p. 84.

1981 Tityrosphaeridium gracile (Eisenack) Sarjeant, p. 121.

Age. LO: early Lutetian.

\section{Cordosphaeridium inodes (Klumpp 1953) Eisenack} $1963 a$

(Plate 5, fig. 10)

1953 Hystrichosphaeridium inodes Klumpp, p. 391, plate 18, figs 1, 2.

1963a Cordosphaeridium inodes (Klumpp) Eisenack, p. 261.

Age. LO: consistent occurrence early Lutetian. Not plotted.

Remarks. The holotype of Cordosphaeridium inodes (Klumpp 1953, plate 18, figs 1, 2) shows considerable variation in the width of the processes, some being remarkably similar to those of Cordosphaeridium gracile. It is this variability in width, however, that is the distinguishing characteristic of Cordosphaeridium inodes.

\section{Genus Cribroperidinium Neale \& Sarjeant 1962}

Type. Neale \& Sarjeant 1962, plate 19, fig. 4, text-fig. 3a, b, as Cribroperidinium sepimentum.

1962 Cribroperidinium Neale \& Sarjeant, p. 443.

1968 Acanthaulax Sarjeant, p. 227.

1978 Millioudodinium Stover \& Evitt, p. 173.

1984b Meristaulax Sarjeant, p. 160.

1988 Meristaulax Brenner, p. 65.

Synopsis. Gonyaulacacean (cribroperidinioid) cysts that are proximate, with spheroidal to more commonly ovoidal central body, usually surmounted by an apical horn. Acavate or cornucavate. Tabulation strongly delineated by sutural and penitabular ornamentation. Archaeopyle precingular, with formula $\mathrm{P}_{3^{\prime \prime}}$, operculum free.

\section{Cribroperidinium giuseppei (Morgenroth 1966a) Helenes 1984}

1966a Gonyaulax giuseppei Morgenroth: 5, plate 2, figs 3-6.

1969 Gonyaulacysta giuseppei (Morgenroth) Sarjeant, p. 9.
1978 Millioudodinium? giuseppei (Morgenroth) Stover \& Evitt, p. 174.

1982 Rhynchodiniopsis? giuseppei (Morgenroth) Sarjeant, p. 36.

1984 Cribroperidinium giuseppei (Morgenroth) Helenes, p. 121.

Age. Local acme: Priabonian.

Remarks. Cribroperidinium giuseppei is a species of Cribroperidinium with a small, button-like apical horn, a spongy wall, distinctly reflected paratabulation and a low, coarse reticulum superimposed on the paraplates. This includes many forms assigned in the literature to Cribroperidinium tenuitabulatum, but the latter species is now considered to be a junior synonym of Apteodinium australiense. Helenes (1984, p. 122) noted that the sutural ridges in Cribroperidinium giuseppei are smooth and that the penitabular ridges are more commonly found on the hypocyst.

Genus Cyclonephelium Deflandre \& Cookson 1955 Type. Deflandre \& Cookson 1955, plate 2, fig. 12, as Cyclonephelium compactum.

1955 Cyclonephelium Deflandre \& Cookson, p. 285.

1961 Circulodinium Alberti, p. 28.

Remarks. We follow the synopsis for this genus proposed by Fensome et al. (2009, p. 24), and agree with those authors in considering Circulodinium to be a junior synonym of Cyclonephelium.

\section{Cyclonephelium distinctum (Deflandre \& Cookson} 1955) Jansonius 1986

(Plate 6, fig. 10)

1955 Cyclonephelium distinctum Deflandre \& Cookson, p. 285, 286, plate 2, fig. 14; textfigs $47,48$.

1961 Circulodinium hirtellum Alberti, p. 28, 29, plate 4, fig. 20.

1969 Canningia hirtella (Alberti) - Millioud, p. 425.

1978 Cyclonephelium hirtellum (Alberti) - Davey, p. 894.

1986 Circulodinium distinctum (Deflandre \& Cookson) - Jansonius, p. 204.

Age. LO: latest Maastrichtian. 


\section{Genus Dapsilidinium Bujak et al. 1980}

Type. Davey \& Williams 1966a, plate 4, fig. 10, as Polysphaeridium pastielsii.

1980

Dapsilidinium Bujak et al., p. 27, 28.

Remarks. For this genus, the concept of Fensome et al. (2009, p. 26) is followed.

\section{Dapsilidinium pseudocolligerum (Stover 1977) Bujak et al. 1980}

(Plate 5, fig. 13)

1977 Polysphaeridium pseudocolligerum Stover, p. 74, 75, plate 1, figs 14-19.

1980 Dapsilidinium pseudocolligerum (Stover) Bujak et al., p. 28.

Age. LO: Tortonian.

Remarks. As Fensome et al. (2009) observed, Dapsilidinium pastielsii and Dapsilidinium pseudocolligerum differ primarily in the proximal morphology of the processes. In Dapsilidinium pastielsii, the processes are initially broad before tapering gradually, whereas in Dapsilidinium pseudocolligerum they are more or less cylindrical proximally, tapering gradually to the distal opening.

\section{Dapsilidinium pseudoinsertum sp. nov.}

(Plate 5, figs 11, 12)

Holotype. Plate 5, fig. 12 from a cuttings sample at 2825-2835 m in Rut H-11, GSC type collection no. 137957, sample P39388, slide 01, co-ordinates $19.6 \times$ 105.1, England Finder U48/1-2. Central body maximum diameter $32 \mu \mathrm{m}$; length of processes up to about 15 $\mu \mathrm{m}$. The age determined for the sample from which the holotype was recovered is Ypresian.

Etymology. The epithet is in reference to the similarity of this species to Hystrichokolpoma? incertum Michoux 1985.

Diagnosis. A species of Dapsilidinium in which some, but not all, of the processes are significantly broader than others, though the position of the broader processes appears not to be consistent.

Size. Central body maximum diameter 30-32 $\mu \mathrm{m}$; length of processes up to about $15 \mu \mathrm{m}$; two specimens measured.

Age. LO: late Lutetian.
Remarks. This species is distinctive in having a more or less bimodal variation in process widths, with a few being distinctly broader than the others. The position and number of broad processes vary from specimen to specimen. One or more of the broader processes on each specimen may be bifurcate distally down to about midlength. In Hystrichokolpoma? incertum, the larger processes are consistently the precingulars and the antapical. In other species of Dapsilidinium, such as Dapsilidinium pseudocolligerum and Dapsilidinium simplex, the processes are more or less uniformly developed. In species of Diphyes, only the antapical process is relatively large.

\section{Dapsilidinium simplex (White 1842) Bujak et al. 1980} (Plate 5, fig. 14)

1842 Xanthidium tubiferum var. simplex White, p. 38, plate 4, fig. 10.

1946 Hystrichosphaeridium simplex (White) Deflandre, card 934.

1969 Polysphaeridium? simplex (White) - Davey \& Williams, p. 7.

1980 Dapsilidinium simplex (White) - Bujak et al., p. 28.

Age. LO: Bartonian. Not plotted.

\section{Genus Deflandrea Eisenack 1938}

Type. Eisenack 1938, text-fig. 6, as Deflandrea phosphoritica.

\section{Deflandrea Eisenack, p. 187.}

Remarks. Deflandrea is a peridiniacean cyst that is characterised by its latideltaform intercalary $\left(\mathrm{I}_{2 \mathrm{a}}\right)$ archaeopyle. The broad shape is a consistently striking feature of the periarchaeopyle, but not always of the endoarchaeopyle.

\section{Deflandrea borealis sp. nov.}

(Plate 5, figs 17-20)

Holotype. Plate 5, fig. 19 from a cuttings sample at 3095-3105 m in Rut H-11, GSC type collection no. 137964, sample P39397, slide 01, co-ordinates $18.9 \times$ 98.6, England Finder T41/2. Length (including horns) $57 \mu \mathrm{m}$, width $55 \mu \mathrm{m}$. The age determined for the sample from which the holotype was recovered is Thanetian (Late Paleocene).

Etymology. The epithet is from the Latin borealis (northern) in reference to the northern occurrence of at least the type material of this species. 
Diagnosis. A relatively small, squat and generally rounded species of Deflandrea with a scabrate to granulate wall and a latiform archaeopyle, the operculum of which commonly remains attached posteriorly.

Size. Length (including horns) 46-59 $\mu \mathrm{m}$, width 46-55 $\mu \mathrm{m}$; three specimens measured.

Age. LO: latest Priabonian.

\section{Deflandrea denticulata Alberti 1959}

(Plate 5, figs 15, 16)

1959 Deflandrea denticulata Alberti, p. 102, 103, text-fig. 1.

Age. LO: Ypresian. Not plotted.

Remarks. Deflandrea denticulata (Alberti 1959, text-fig. 1 ) is unusual for a species of this genus in having a pericyst with long slender apical and antapical horns. The periphragm is covered with small, slender spines. Although the archaeopyle appears to be latideltaform, it is impossible to be definite without examining the holotype. Alberti (1959) recorded Deflandrea denticulata from Lower Eocene sediments of Volgograd, Russia, the Oebisfelde Borehole in Germany, and possibly from Belgium. His observations fit the predicted LO in this study for a taxon with a morphology intermediate between Cerodinium and Deflandrea.

\section{Deflandrea galeata (Lejeune-Carpentier 1942) Lentin \& Williams 1973}

(Plate 6, fig. 1)

1942 Peridinium galeata Lejeune-Carpentier, p. B186-B188, figs 15-20.

1973 Deflandrea galeata (Lejeune-Carpentier) Lentin \& Williams, p. 41.

Age. LO: Maastrichtian.

Remarks. The line-drawing of the dorsal view of the holotype of Deflandrea galeata (Lejeune-Carpentier 1942, fig. 15) clearly shows a latideltaform hexa $2 \mathrm{a}$ archaeopyle. This interpretation is confirmed in Lejeune-Carpentier \& Sarjeant (1981, p. 18, 19, who refer to the archaeopyle as "single-plate intercalary (type I/I) of broad-hexa type and formed by the loss of paraplate $2 \mathrm{a}$ ”. In every other respect, the species has the typical morphology of Cerodinium. It is unusual to find forms with a latideltaform $2 \mathrm{a}$ in rocks of this age.

Deflandrea majae (Schiøler 1993) comb. nov. (Plate 6, fig. 2)

1993 Isabelidinium majae Schiøler, p. 108, 110, plate 1, figs 1-6; text-fig. 4a, b.

Age. LO: latest Maastrichtian.

Remarks. Schiøler (1993) noted that this species has a latideltaform archaeopyle with a transverse archaeopyle index (TAI) considerably higher than 0.5. Schiøler (1993, p. 110) stated that although these characters are “... typical of the genus Deflandrea ... as the new species lacks any signs of a paracingulum, referral to the latter genus is precluded." In our view, archaeopyle shape is critical in diagnosing Deflandrea and similar genera and that the presence or absence of a cingulum is not significant. Therefore, this species is transferred herein to Deflandrea. However, M. Pearce (personal communication 2015) has pointed out that the archaeopyles of specimens otherwise attributable to this species show a wide variation in archaeopyle shape. For example he has observed specimens of Deflandrea majae with stenodeltaform archaeopyles; we would recommend that such forms be included in another genus. As noted under Alterbidinium, a detailed re-evaluation of archaeopyle shapes in Deflandrea and similar genera in relation to the taxonomy of the group is clearly needed but beyond the scope of the present work.

\section{Deflandrea oebisfeldensis Alberti 1959}

(Plate 6, fig. 3)

Deflandrea oebisfeldensis Alberti, p. 95, 96, plate 8 , figs 10-13.

Age. LO: early Ypresian.

Remarks. The antapical margin of the pericyst in Deflandrea oebisfeldensis is broad, with the left and right antapical horns being at the intersection with the posterior lateral sides and thus broadly separated.

\section{Deflandrea phosphoritica Eisenack 1938}

(Plate 6, fig. 4)

1938 Deflandrea phosphoritica Eisenack, p. 187, text-fig. 6. 
1965b Deflandrea granulosa Cookson \& Eisenack, p. 122, plate 11, figs 8, 9 .

1965 Deflandrea heterophlycta forma pusulosa Rozen, p. 293, 294, plate 1, figs 3, 4; text-fig. 2.

1966 Deflandrea menendezii Pöthe de Baldis, p. 223, plate 2, fig. a.

1973 Deflandrea heterophlycta subsp. pusulosa (Rozen) - Lentin \& Williams, p. 41.

Age. LO: latest Chattian.

\section{Genus Dinogymnium Evitt et al. 1967}

Type. Evitt et al. 1967, plate 1, figs 21-23, plate 2, fig. 5, text-figs 16-18, as Dinogymnium acuminatum.

1967 Dinogymnium Evitt et al., p. 4-8.

Remarks. Lentin \& Vozzhennikova (1990) subdivided the dinogymnioids into genera that are separated on overall outline, relative size of the episome and hyposome, and surface ornamentation. As a consequence, these authors transferred several species previously included in Dinogymnium into the new genera. Fensome et al. (2009, p. 27) provided a synopsis for Dinogymnium that is followed here.

\section{Dinogymnium longicorne (Vozzhennikova 1967) Harland 1973}

(Plate 6, fig. 11)

1967 Gymnodinium longicorne Vozzhennikova, p. 46, plate 1, fig. 8; plate 3, fig. 6; plate 4, figs $6 a, b, 7$.

1967 Gymnodinium curvatum Vozzhennikova, p. 43, plate 1, figs 10-12; plate 4, figs 2, 3 .

1973 Dinogymnium longicorne (Vozzhennikova) Harland, p. 678.

Age. LO: early Campanian.

Remarks. Dinogymnium longicorne is elongate, with an episome that is considerably longer than the hyposome. According to Lentin \& Vozzhennikova (1990, p. 19), the length varies between 62 and $91 \mu \mathrm{m}$, the width between 21 and $38 \mu \mathrm{m}$.

Genus Diphyes Cookson 1965 nom. cons.

Type. Deflandre \& Cookson 1955, plate 7, fig. 3, as Hystrichosphaeridium colligerum.

Diphyes Cookson, p. 85; name illegitimate.
1970 Lingulasphaera Drugg, p. 817.

2000 Diphyes Cookson nom. prop. cons. Harris \& Fensome, p. 281, 282.

Remarks. The conservation proposal of the name Diphyes Cookson (Harris \& Fensome 2000) was ratified at the 2005 Botanical Congress. We agree with the synopsis of Diphyes in Fensome et al. (2009, p. 28), with one exception regarding the processes. Some specimens show an intratabular organisation, with about four processes on each pre- and postcingular plate.

\section{Diphyes brevispinum Bujak 1994}

(Plate 6, figs 5, 6)

1994 Diphyes brevispinum Bujak, p. 121, 123, plate 2, figs 4-6.

Age. LO: Ypresian.

Remarks. Diphyes brevispinum has short conical to subconical, rarely tapering processes and an inflated antapical process that is similar to that of Diphyes ficusoides.

\section{Diphyes colligerum (Deflandre \& Cookson 1955) Cookson 1965}

(Plate 6, fig. 12)

1955 Hystrichosphaeridium colligerum Deflandre \& Cookson, p. 278, 279, plate 7, fig. 3.

1965 Baltisphaeridium colligerum (Deflandre \& Cookson) - Downie \& Sarjeant, p. 88.

1994 Diphyes pseudoficusoides Bujak, p. 123, 125, plate 2, figs 2, 3.

Age. LO: Lutetian.

Remarks. Following Fensome et al. (2009, p. 30), Diphyes pseudocolligerum should be considered a junior synonym of Diphyes colligerum because the size of the antapical process is similar in both holotypes.

\section{Diphyes ficusoides Islam 1983a}

(Plate 6, figs 7, 8)

1983a Diphyes ficusoides Islam, p. 338, plate 2, figs 8, 9.

Age. LO: middle Lutetian. 


\section{Genus Disphaerogena Wetzel 1933a}

Type. Wetzel 1933a, plate 4, fig. 34, as Disphaerogena carposphaeropsis.

1933a Disphaerogena Wetzel, p. 51.

1976 Cyclapophysis Benson, p. 192.

1981 Plethysyrinx Sarjeant, p. 106.

Remarks. The synopsis of Disphaerogena provided in Fensome et al. (2009, p. 30) is accepted, including that Cyclapophysis is a taxonomic junior synonym of the genus.

\section{Disphaerogena carposphaeropsis Wetzel 1933a}

(Plate 6, fig. 9)

1933a Disphaerogena carposphaeropsis Wetzel, p. 51, plate 4, fig. 34.

1976 Cyclapophysis monmouthensis Benson, p. 183, plate 1, figs 9-12; plate 2, fig. 1 .

Age. LO: latest Maastrichtian.

Remarks. When Sarjeant (1985a, p. 141, 142) emended the diagnosis of Disphaerogena carposphaeropsis, he considered Cyclapophysis monmouthensis to be a taxonomic junior synonym of the species.

\section{Genus Eatonicysta Stover \& Evitt 1978}

Type. Morgenroth 1966a, plate 3, fig. 11, as Cannosphaeropsis ursulae.

\section{Eatonicysta Stover \& Evitt, p. 41.}

Synopsis. Gonyaulacacean (leptodinioid) cysts that are chorate, with a spheroidal central body. Holocavate. Central body bearing 17 to 23 hollow or solid, fibroid mesotabular processes, which are distally connected by a fenestrate to reticulate to irregular open-mesh, net-like ectophragm. Archaeopyle apical, with formula $A_{\left(1-4^{\prime}\right)}$, operculum free.

Description. The holocavate cyst has an autophragm bearing mesotabular processes with expanded distal extremities that merge to form a perforate membranous to reticulate to trabeculate ectophragm. The size of the mesh or perforations shows considerable variation. A leptodinioid tabulation of 3-4', 6"'", 0-6c, 5"', $1{ }^{\prime \prime \prime \prime}, 0 \mathrm{~s}$ is indicated by the processes. Based on process size, plate 1 " would be wider than 6 ".
Remarks. Eatonicysta is characterised by a membranous ectophragm that may be reticulate or broken down to form a trabeculate network.

Eatonicysta furensis (Heilmann-Clausen in HeilmannClausen \& Costa 1989) Stover \& Williams 1995

(Plate 6, fig. 13)

1989 Eatonicysta ursulae subsp. furensis HeilmannClausen in Heilmann-Clausen \& Costa, p. 466, plate 11 , figs $3,5,7$.

1995 Eatonicysta furensis (Heilmann-Clausen in Heilmann-Clausen \& Costa) - Stover \& Williams, p. 104.

Age. LO: late Ypresian.

Remarks. Eatonicysta furensis has much shorter, usually broader, funnel-shaped processes than Eatonicysta ursulae. Also, the processes grade imperceptibly into the ectophragm, which is divided into areas reflecting the individual plates, rather than forming a continuous network.

\section{Eatonicysta ursulae (Morgenroth 1966a) Stover \& Evitt 1978}

(Plate 6, fig. 14)

1966a Eatonicysta ursulae Morgenroth, p. 20, plate 3, figs 11, 12 .

1966a Membranilarnacia reticulata Williams \& Downie, p. 220, 221, plate 24, figs 4, 6; text-fig. 59.

1967 Membranilarnacia dictyophora Agelopoulos, p. 49, 50, plate 12, figs 3, 4, 6 .

1969 Membranilarnacia ursulae (Morgenroth) - de Coninck, p. 43.

1978 Eatonicysta ursulae (Morgenroth) - Stover \& Evitt, p. 41.

Age. LO: earliest Lutetian.

Remarks. Williams \& Downie (1966a) recorded two variants of Eatonicysta ursulae (as Membranilarnacia reticulata, a synonym of Eatonicysta ursulae) from the Ypresian London Clay from southern England. One lacked cingular processes, the other had four cingular processes. Whether or not this variation is stratigraphically significant remains to be confirmed.

\section{Genus Enneadocysta Stover \& Williams 1995}

Type. Gerlach 1961, plate 28, fig. 14, as Baltisphaeridium pectiniforme. 
1994 Enneadocysta Stover \& Williams in Bujak, p. 119; name not validly published.

1995 Enneadocysta Stover \& Williams, p. 108, 109.

2007 Enneadocysta Stover \& Williams - emend.

Fensome et al., p. 394.

Remarks. We follow the emendation of Fensome et al. (2007, p. 394) in our concept for this genus and agree that it is areoligeracean.

\section{Enneadocysta magna Fensome et al. 2007}

(Plate 7, figs 1, 2)

2007 Enneadocysta magna Fensome et al., p. 394, 396 , plate 1 , figs $1-20$; plate 2 , figs $1-19$; text-figs $5 \mathrm{~A}, \mathrm{~B}, 6 \mathrm{~A}-\mathrm{E}$.

Age. LO: latest Rupelian.

Remarks. Labrador Margin specimens of Enneadocysta magna can have process clusters on individual plates.

\section{Genus Eocladopyxis Morgenroth 1966a}

Type. Morgenroth 1966a, plate 3, figs 2, 3, as Eocladopyxis peniculata.

1966a Eocladopyxis Morgenroth, p. 7.

Remarks. The synopsis provided by Fensome et al. (2009, p. 31) takes into account that Eocladopyxis is a goniodomacean (pyrodinioid) cyst and identifies all the plates involved in the formation of the archaeopyle.

\section{Eocladopyxis peniculata Morgenroth 1966a}

(Plate 7, fig. 3)

1966a Eocladopyxis peniculata Morgenroth, p. 7, 8, plate 3, figs 2, 3.

Age. LO: late Ypresian.

\section{Genus Evittosphaerula Manum 1979 emend. Damassa 1997}

Type. Manum 1979, plate 2, figs 3, 4, as Evittosphaerula paratabulata.

1979 Evittosphaerula Manum, p. 242, 243.

1997 Evittosphaerula Manum - emend. Damassa, p. 161-163.

\section{Evittosphaerula? foraminosa sp. nov.}

(Plate 6, figs 15-20)

Holotype. Plate 6, figs 19, 20 from a cuttings sample at 2130-2140 m in North Leif I-05, GSC type collection no. 138159, sample YD17600, slide 03, co-ordinates $44.9 \times 15.5$, England Finder M43/0. Pericyst length $82.5 \mu \mathrm{m}$, width $90 \mu \mathrm{m}$. The age determined for the sample from which the holotype was recovered is Ypresian.

Etymology. From the Latin foraminosus, meaning 'full of holes'.

Description. A species of gonyaulacalean cysts in which only broad strips of membrane representing the sutures are preserved. The tabulation appears to be goniodomaceans, with a five-sided antapical plate reflecting a quinqueform hypocystal tabulation. At the apex, sutural strips come together to form a short apical horn.

Size. Diameter 68-90 $\mu \mathrm{m}$; four specimens in dorsoventral orientation measured, but excluding the holotype as it is oriented apically-antapically.

Age. LO: Ypresian.

Remarks. This species has a very distinctive structure, represented by strips of membrane reflecting the sutures only; the internal area of each plate is represented by a hole. Thus the species is reminiscent of the late Oligocene to early Miocene species Evittospaherula paratabulata, but differs superficially in having an apical horn, an apparently much narrower cingulum, and broader sutural membranes. More fundamentally, one specimen (Plate 6, fig. 18) appears to have a five-sided antapical plate, suggesting a goniodomacean affinity (Fensome et al. 1993). The tabulation described by Manum (1979) for Evittosphaerula paratabulata, the type of the genus, is clearly gonyaulacacean. As this new species is strikingly similar, albeit perhaps superficially, to Manum's species, and there is not sufficient material to describe its tabulation in full, it is questionably assigned to Evittosphaerula. The new species is also strikingly similar to both Hapsocysta susanae, described by Duxbury (2002) from the Albian of the central North Sea, and Chaenosphaerula magnifica, described by Damassa (1997) from the late Oligocene of the Norwegian Sea. However, the tabulation of both those species is clearly sexiform, and neither has horns. 
Genus Fibrocysta Stover \& Evitt 1978

Type. Cookson \& Eisenack 1965b, plate 16, fig. 8, as Cordosphaeridium bipolare.

1978 Fibrocysta Stover \& Evitt, p. 155.

Synopsis. Gonyaulacacean (cribroperidinioid) cysts that are chorate, with a longitudinally elongate ovoidal central body, with a protrusion at the apical and antapical poles. Acavate or cornucavate, with a fibrous wall. Processes numerous, nontabular to indistinctly tabular; they are hollow and fibrous or solid and generally of uniform size. Archaeopyle precingular, with formula $\mathrm{P}_{3^{\prime \prime}}$, operculum free.

Remarks. In wall structure and archaeopyle type, Fibrocysta is very similar to Turbiosphaera. However, processes in Turbiosphaera are wider, especially apically and antapically, and in Turbiosphaera, the cingulum is marked by a membrane. The remarkable similarities between the two genera suggest that Fibrocysta, like Turbiosphaera, has a cribroperidinioid tabulation.

\section{Fibrocysta bipolaris (Cookson \& Eisenack 1965a)} Stover \& Evitt 1978

(Plate 7, fig. 4)

1965a Cordosphaeridium bipolare Cookson \& Eisenack, p. 135, plate 16, figs 7, 8 .

1969 Lanternosphaeridium bipolare (Cookson \& Eisenack) - de Coninck, p. 38.

1969c Amphorosphaeridium bipolare (Cookson \& Eisenack) - Davey, p. 35.

1978 Fibrocysta bipolaris (Cookson \& Eisenack) Stover \& Evitt, p. 155.

Age. Local acme early Ypresian.

Remarks. The cingulum of the holotype of Fibrocysta bipolaris (Cookson \& Eisenack 1965a, plate 16, fig. 8) appears to be delineated by a single row of processes.

\section{Genus Gillinia Cookson \& Eisenack 1960a}

Type. Cookson \& Eisenack 1960a, plate 3, fig. 4, as Gillinia hymenophora.

1960a Gillinia Cookson \& Eisenack, p. 11, 12.

Synopsis. Small, proximate, slightly elongate cysts with two membranous wings, one on each side of the apical archaeopyle. Tabulation partially delineated by ridges, which commonly define the cingulum and a sulcal area that is considerably broader posteriorly.

Remarks. Following Fensome et al. (1993, p. 73), Gillinia probably has a cladopyxiacean tabulation.

\section{Gillinia hymenophora Cookson \& Eisenack 1960a} (Plate 7, fig. 12)

1960a Gillinia hymenophora Cookson \& Eisenack, p. 12 , plate 3, figs 4-6; text-fig. 5 .

Age. LO: late Campanian.

Genus Ginginodinium Cookson \& Eisenack 1960a Type. Cookson \& Eisenack 1960a, plate 2, fig. 9, as Ginginodinium spinulosum.

\section{0a Ginginodinium Cookson \& Eisenack, p. 7.}

Remarks. In their emendation of Ginginodinium, Lentin \& Williams $(1976$, p. 95, 96) noted that the archaeopyle is compound, involving the three anterior intercalary plates and three of the precingular plates $\left(3^{\prime \prime}-5^{\prime \prime}\right)$. However, the archaeopyle may be formed from loss of only the three anterior intercalary plates. There may also be a series of successive stages, until all three intercalaries are lost and three of the precingulars remain attached to the main cyst solely along the cingular margin. This variability in archaeopyle type often makes assignment of species to the genus difficult.

\section{Ginginodinium? flexidentatum sp. nov.}

(Plate 7, figs 5-11)

Holotype. Plate 7 , fig. 11, from a cuttings sample at 1815-1825 m in Bjarni O-82, GSC type collection no. 138070, sample P39715, slide 01, co-ordinates $3.6 \times$ 102.8, England Finder C32/4. Pericyst length $84 \mu \mathrm{m}$, width $73 \mu \mathrm{m}$, endocyst length $61 \mu \mathrm{m}$, width $67 \mu \mathrm{m}$, length of processes up to $2.5 \mu \mathrm{m}$. The age determined for the sample from which the holotype was recovered is early Ypresian.

Etymology. The epithet is from the Latin flexibilis, meaning bendable and dentatus, meaning toothed or pointed.

Diagnosis. A species of Ginginodinium with one or more lateral horns or bulges, a flexible folded wall, and no clearly demarked cingulum. The ornament is variable but typically denticulate. 
Description. Pericyst outline pentagonal, with a welldeveloped apical and two antapical horns, one of which is slightly shorter than the other, and two lateral protuberances. Generally cornucavate but can, in part or whole, be circumcavate. The endocyst is pentagonal. Pericyst ornamentation varies from finely perforate to verrucate to bearing processes. The archaeopyle involves the loss of the $2 \mathrm{a}$ plate, which remains attached to the 4 " "plate, and sometimes the partial detachment of the 1a and 3a plates. One margin of the cingulum is commonly indicated by a fold.

Size. Pericyst length $61-87 \mu \mathrm{m}$ (mean $73 \mu \mathrm{m})$, pericyst width 56-73 $\mu \mathrm{m}$ (mean $63 \mu \mathrm{m}$ ), endocyst length 43 $61 \mu \mathrm{m}$ (mean $51 \mu \mathrm{m})$, width 49-67 $\mu \mathrm{m}$ (mean $53 \mu \mathrm{m})$, process length up to about $2.5 \mu \mathrm{m}$.

Age. LO: late Ypresian.

Remarks. The shapes of the pericyst and endocyst are relatively stable in Ginginodinium? flexidentatum, but there are differences between specimens in degree of cavation, which can range from cornucavate to narrowly circumcavate. There are also variations in the shape of the horns, especially the apical: this is generally rounded distally but may be acuminate. The antapical horns are acuminate to rounded distally; the lateral horns are primarily just protuberances. Pericyst ornamentation is variable, sometimes even on the same specimen. The periphragm can be perforated and ornamented with small verrucae and processes, the latter of variable length. Processes are slender and distally bifid. This species is included in Ginginodinium only provisionally because of the uncertainty over the archaeopyle.

\section{Genus Glaphyrocysta Stover \& Evitt 1978}

Type. Cookson 1965, plate 11, fig. 4, as Cyclonephelium retiintextum.

\section{Glaphyrocysta Stover \& Evitt, p. 49, 50.}

Remarks. The generic concept of Glaphyrocysta, as expressed in the emendation by Fensome et al. (2009, p. 32 ), is followed here. The genus is sometimes abundant in middle Eocene sections in Labrador Margin wells.

\section{Glaphyrocysta divaricata (Williams \& Downie 1966a) Stover \& Evitt 1978}

(Plate 7, figs 15, 16) 1966a Cyclonephelium divaricatum Williams \& Downie, p. 223, 224, plate 25, fig. 1; text-fig. 60.

1978 Glaphyrocysta divaricata (Williams \& Downie) - Stover \& Evitt, p. 50.

Age. LO: earliest Lutetian. See also Remarks.

Remarks. A species of Glaphyrocysta with numerous processes variously interconnected along their length, but with a preponderance of distal free ends. In Glaphyrocysta divaricata, unlike in Glaphyrocysta ordinata and Glaphyrocysta retiintexta, the processes do not form distinct complexes. Although this taxon has a Lutetian LO, it is most abundant in the Paleocene and is often very common to dominant in assemblages from that epoch.

\section{Glaphyrocysta exuberans (Deflandre \& Cookson 1955 ex Eaton 1976) Stover \& Evitt 1978 \\ (Plate 7, fig. 14)}

1955 Cyclonephelium exuberans Deflandre \& Cookson, p. 255; name not validly published.

1976 Cyclonephelium exuberans Deflandre \& Cookson ex Eaton, p. 255, 256.

1978 Glaphyrocysta exuberans (Deflandre \& Cookson ex Eaton) - Stover \& Evitt, p. 50.

Age. LO: Priabonian.

Remarks. Glaphyrocysta exuberans has a well-developed, often perforate, marginate ectophragm, supported by solid, slender processes.

\section{Glaphyrocysta retiintexta (Cookson 1965) Stover \& Evitt 1978}

(Plate 7, fig. 17)

1965 Cyclonephelium retiintextum Cookson, p. 88, plate 11, fig. 4.

1978 Glaphyrocysta retiintexta (Cookson) - Stover \& Evitt, p. 50.

Age. LO: Priabonian.

Remarks. Glaphyrocysta retiintexta shows an ambital development of distal trabecula but has minimal membrane development. The general absence of membranes and the distal connections between plate complexes distinguish this species from Glaphyrocysta intricata. Fensome et al. (2009, p. 34) noted that the morphology of Glaphyrocysta retiintexta was very similar to that shown in the drawing 
of the holotype of Glaphyrocysta pastielsii (Deflandre \& Cookson 1955) Stover \& Evitt 1978 by Pastiels (1948, plate 5, fig. 15). But Fensome et al. (2009) also stated that photographs of the holotype of Glaphyrocysta pastielsii appeared to possess a morphology more like that of Glaphyrocysta divaricata. Accordingly they recommended restricting the name Glaphyrocysta pastielsii to the holotype, a proposal followed here.

\section{Glaphyrocysta texta (Bujak 1976) Stover \& Evitt 1978 (Plate 8, fig. 1)}

1976 Cyclonephelium texta Bujak, p. 110, plate 3, figs 6-11; text-fig. 3G, $\mathrm{H}$.

1978 Glaphyrocysta texta (Bujak) - Stover \& Evitt, p. 50 .

Age. LO: Priabonian.

Remarks. Glaphyrocysta texta has distinctive process complexes on most of the pre- and postcingular plates, and apparently one broader complex on the single antapical plate. The contabular complexes consist of slender intratabular processes, distally united to form clypeate platforms that have ragged margins. The $3^{\prime \prime}$ and $3^{\prime \prime \prime}$ plates sometimes have a single process rather than a process complex. Adjacent process complexes are connected distally by trabecula.

\section{Glaphyrocysta vicina (Eaton 1976) Stover \& Evitt 1978}

(Plate 8, fig. 2)

1976 Cyclonephelium vicinum Eaton, p. 260, 261, plate 8, figs 4, 5; text-fig. 13.

1978 Glaphyrocysta vicina (Eaton) - Stover \& Evitt, p. 50.

Age. LO: Lutetian.

Remarks. Glaphyrocysta vicina has a marginal, perforate pericoel, with the periphragm remaining close to the endophragm. Both features are unusual in species of Glaphyrocysta. Species of Membranophoridium lack processes supporting the periphragm.

\section{Genus Habibacysta Head et al. 1989}

Type. Head et al. 1989, plate 4, figs 1, 2, 5, 6, as Habibacysta tectata.

1989 Habibacysta Head et al., p. 457, 458.
Synopsis. Proximate spheroidal gonyaulacean cysts. Atabulate. Autophragm bearing short columns that distally are sometimes united by an entire, perforate or reticulate layer. Archaeopyle precingular, with formula $\mathrm{P}_{3^{\prime \prime}}$, operculum free.

Remarks. Head (1994, text-fig. 3) showed how the nature of the autophragm differentiates Habibacysta from Bitectatodinium, Filisphaera and Tectatodinium. All four genera are proximate, atabulate gonyaulacacean cysts with precingular archaeopyles.

\section{Habibacysta tectata Head et al. 1989}

(Plate 7, fig. 13)

1989 Habibacysta tectata Head et al., p. 458, plate 4, figs 1-6, 9, 10.

Age. LO: earliest Zanclean.

\section{Genus Hapsocysta Davey 1979}

Type. Eisenack \& Cookson 1960, plate 3, fig. 6, as Cannosphaeropsis peridictya.

1979 Hapsocysta Davey, p. 556.

Synopsis. A chorate to camocavate gonyaulacacean (gonyaulacoidean) cyst, with a subrounded to ovoidal central body, which is surrounded by a periphragm that may be trabeculate, forming an open network, or filled by a perforate membrane. Tabulation indicated by the trabecula, which on membranous taxa occur as ridges. Archaeopyle precingular, with formula $\mathrm{P}_{3^{\prime \prime}}$, operculum free.

Remarks. Fensome et al. (1993, p. 89) considered Hapsocysta to have a cribroperidinioid tabulation. However, Nøhr-Hansen (1993, p. 71, 72) showed that the taxon, which he named Hapsocysta? benteae, had gonyaulacoidean tabulation. Nøhr-Hansen (1993) provisionally included the species in Hapsocysta, because of the presence of the thin-walled periphragm.

\section{Hapsocysta? benteae Nøhr-Hansen 1993}

(Plate 8, fig. 12)

1993 Hapsocysta? benteae Nøhr-Hansen, p. 71, 72, plate 25, figs 11, 12; text-figs $10 \mathrm{a}, \mathrm{b}, 11 \mathrm{a}, \mathrm{b}$.

Age. LO: Cenomanian. 


\section{Genus Heteraulacacysta Drugg \& Loeblich Jr.} 1967

Type. Drugg \& Loeblich Jr. 1967, plate 1, fig. 8a-c, as Heteraulacacysta campanula.

1967 Heteraulacacysta Drugg \& Loeblich Jr., p. 183.

Remarks. The synopsis for Heteraulacacysta by Fensome et al. (2009, p. 35) is followed.

Heteraulacacysta porosa Bujak in Bujak et al. 1980 (Plate 8, fig. 16)

1980 Heteraulacacysta porosa Bujak in Bujak et al., p. 62 , plate 15 , figs $10-13$; text-fig. $14 \mathrm{~B}, \mathrm{C}$.

Age. LO: Priabonian.

Remarks. Considerable uncertainty has prevailed over the distinction between Heteraulacacysta leptalea Eaton 1976 and Heteraulacacysta porosa. In his diagnosis for Heteraulacacysta leptalea, Eaton (1976, p. 305) stated: "Circular fenestrations frequently developed in the proximal area of the cingular crests, along with fine elongate fenestrations aligned at right-angles to the margin of the cyst body." Under 'Remarks', Eaton commented that small perforations occurred in the periphragm, comparable to those in the proximal area of the cingular crests, and commonly gave a punctate appearance to the wall. In the succeeding sentence, Eaton (1976, p. 305) differentiated Heteraulacacysta leptalea from Heteraulacacysta campanula on the basis of its "...frequently punctuate rather than positively ornamented surface to the cyst body, and in exhibiting circular and elongate fenestrations in the cingular crests."

Bujak in Bujak et al. (1980, p. 62) differentiated Heteraulacacysta porosa "... from all other described species of Heteraulacacysta by its perforate periphragm." The illustrations of the holotype and another specimen of Heteraulacacysta leptalea in Eaton (1976, plate 21, figs 1,2$)$ clearly show perforations. Consequently, the only consistent difference appears to be the presence of elongate perforations on the cingular crests in Heteraulacacysta leptalea. We do not know, however, whether this feature is stratigraphically significant.

\section{Genus Heterosphaeridium Cookson \& Eisenack 1968}

Type. Cookson \& Eisenack 1968, text-fig. 4H, as $\mathrm{He}$ terosphaeridium conjunctum.

\section{Heterosphaeridium Cookson \& Eisenack, p 115.}

Remarks. In their synopsis for Heterosphaeridium, Fensome et al. (2009, p. 35) recognised that it is an areoligeracean cyst with a spheroidal to broadly ovoidal central body. Yun Hyesu (1981, p. 45, 46) provided an emended diagnosis that broadened the circumscription mainly to include forms with hollow, open processes as well as solid processes. Some of the specimens of Heterosphaeridium difficile observed in the present study have processes that are perforated or circular (annulate) process complexes that can be connected at various locations along their length.

Heterosphaeridium bellii Radmacher et al. 2014 (Plate 8, figs 3, 4)

2014 Heterosphaeridium bellii Radmacher et al., p. 31-33, plate 1, figs 1-9.

Age. LO: late Campanian.

Remarks. Heterosphaeridium bellii differs from Heterosphaeridium heteracanthum in having dolabrate processes that are not branching. The processes in Heterosphaeridium bellii may be connected proximally but are never branched along their length. Radmacher et al. (2014) considered the LO of Heterosphaeridium bellii to be late Campanian to early Maastrichtian in the southwestern Barents Sea.

\section{Heterosphaeridium difficile (Manum \& Cookson 1964) Ioannides 1986}

(Plate 8, fig. 8)

1964 Hystrichosphaeridium difficile Manum \& Cookson, p. 12-14, plate 3, figs 1-3, 7.

1986 Heterosphaeridium difficile (Manum \& Cookson) - Ioannides, p. 24.

Age. LO: early Santonian.

Remarks. Labrador Margin specimens of Heterosphaeridium difficile show extreme variation in the nature of the processes. Some are perforate along their length or arched so that the process walls merge distally. Others, as noted under 'Remarks' for the genus, have process complexes on the pre- and postcingular plates that are connected by circular proximal membranes, as in Systematophora. In the latter specimens, the cingular plates have linear process complexes. In some specimens, the apical plates com- 
monly show a characteristic X-shaped crest as observed by M. Pearce (personal communication 2015) and also appear to have annulate process complexes. The antapical plate is marked by an annulate complex that is broader than those on the pre- and postcingular plates. The wall of the central body is microreticulate.

\section{Genus Histiocysta Davey 1969a}

Type. Davey 1969a, plate 1, fig. 5, text-fig. 14A, B, as Histiocysta palla.

\section{9a Histiocysta Davey, p. 138.}

Remarks. This genus is similar to Corrudinium in its shape and ornamentation, but tends to be smaller and has an apical archaeopyle.

\section{Histiocysta palla Davey 1969a}

(Plate 7, figs 18-20)

1969a Histiocysta palla Davey, p. 138-140, plate 1, figs 5, 6; text-fig. 14A, B.

Age. LO: late Campanian.

\section{Genus Homotryblium Davey \& Williams 1966a}

Type. Davey \& Williams 1966a, plate 12, fig. 5, as Homotryblium tenuispinosum.

1966a Homotryblium Davey \& Williams, p. 100.

Remarks. The synopsis provided by Fensome et al. (2009, p. 35, 36) covers all the key morphological attributes of Homotryblium.

\section{Homotryblium abbreviatum Eaton 1976}

(Plate 8, figs 9, 10)

\section{Homotryblium abbreviatum Eaton, p. 267,} 268 , plate 10 , figs $2-4$.

Age. LO: late Ypresian. Not plotted.

Remarks. As in the type material, the Labrador Margin specimens of Homotryblium abbreviatum have short and wide processes, but the surface ornamentation of the central body can be smooth as well as granulate. This species is not as common as Homotryblium tenuispinosum in the samples studied here.
Homotryblium tenuispinosum Davey \& Williams 1966a

(Plate 8, figs 5-7)

1966a Homotryblium tenuispinosum Davey \& Williams, p. 101, 102, plate 4, fig. 11; plate 12, figs $1,5,7$; text-fig. 21.

1966a Homotryblium pallidum Davey \& Williams, p. 102, 103, plate 12, figs 4, 6; text-fig. 22.

Age. LO: Bartonian; peak: latest Ypresian.

Genus Hystrichokolpoma Klumpp 1953

Type. Klumpp 1953, plate 17, figs 3, 5a, as Hystrichokolpoma cinctum.

\section{Hystrichokolpoma Klumpp, p. 388.}

Remarks. Fensome et al. (2009, p. 36) provided a detailed synopsis for Hystrichokolpoma, which stipulated among other morphologic attributes, that the genus must have cingular processes.

Hystrichokolpoma cinctum Klumpp 1953

(Plate 8, fig. 11)

1953 Hystrichokolpoma cinctum Klumpp, p. 389, plate 17 , figs $3,4,5 \mathrm{a}-\mathrm{d}$.

Age. LO: Burdigalean according to Williams et al. (2004), but we consider that the age range of this species needs to be better constrained. Not plotted.

Remarks. A species of Hystrichokolpoma in which the preand postcingular processes fill plates and have small tubular extensions. There are generally two processes per cingular paraplate.

\section{Hystrichokolpoma globulus Michoux 1985}

(Plate 8, figs 13-15)

1985 Hystrichokolpoma globulus Michoux, p. 143, plate 1 , figs $1-4,12$; text-fig. $2 \mathrm{~A}, \mathrm{~B}$.

Age. LO: late Ypresian. Not plotted.

Remarks. Michoux (1985, p. 143) compared Hystrichokolpoma globulus to Hystrichokolpoma cinctum Klumpp 1953, from which it differs by having a much shorter antapical process relative to the length of the cyst and pre- and postcingular processes that do not branch into 
tubules distally. Also, the cingular and sulcal processes are conical and there are three to five on each cingular plate. The Labrador Margin specimens of Hystrichokolpoma globulus differ from the type material in not having conical cingular plates and in there being only three or less on each plate.

\section{Genus Hystrichosphaeridium Deflandre 1937}

Type. Ehrenberg 1838, plate 1, fig. 16, as Xanthidium tubiferum.

\section{Hystrichosphaeridium Deflandre, p. 68.}

Remarks. We concur with the synopsis provided by Fensome et al. (2009, p. 38) except to note that individual processes proximally do not cover most of the underlying plate and that the cingular and sulcal processes are slender. The apical processes also tend to be slender, especially the first and fourth. Variation in process dimensions in Hystrichosphaeridium does not approach the strong variation that is distinctive of Hystrichokolpoma.

Hystrichosphaeridium quadratum sp. nov.

(Plate 8, figs 17-19)

Holotype. Plate 8 , figs 17,18 , from a cuttings sample at 2770-2780 m in Gilbert F-53, GSC type collection no. 137988, sample P39505, slide 01, co-ordinates $11.3 \times$ 99.2, England Finder L29/3. Diameter of central body $44 \mu \mathrm{m}$, length of processes up to about $37 \mu \mathrm{m}$. The age determined for the sample from which the holotype was recovered is early Ypresian.

Etymology. From the Latin quadratus (four-cornered), in reference to the rectangular distal endings of the processes in this species.

Diagnosis. A species of Hystrichosphaeridium in which the distal process endings are slightly flared and polygonal, generally rectangular and commonly perforate. The process bases are mesotabular and circular.

Size. Width of central body $36-48 \mu \mathrm{m}$, length of central body (when operculum in place) $46-63 \mu \mathrm{m}$; processes up to $39 \mu \mathrm{m}$ long. Six specimens measured.

Age. LO: Selandian. Not plotted.

Remarks. This species differs from Hystrichosphaeridium tubiferum in having rectangular endings to its processes. It also resembles Hystrichokolpoma proprium, but the holotype of that species has rounded polygonal process bases that largely fill the plate (see Fauconnier \& Masure 2004, plate 40, figs 1-3), as is typical of the genus Hystrichokolpoma. Hystrichosphaeridium salpingophorum differs in lacking perforations in the distal endings of the processes.

\section{Hystrichosphaeridium tubiferum (Ehrenberg 1838) Deflandre 1937 \\ (Plate 8, fig. 20)}

1838 Xanthidium tubiferum Ehrenberg, plate 1, fig. 16. 1937 Hystrichosphaeridium tubiferum (Ehrenberg) Deflandre, p. 68.

Age. LO: Lutetian.

\section{Genus Hystrichosphaeropsis Deflandre 1935}

Type. Deflandre 1935, plate 8, fig. 11, as Hystrichosphaeropsis ovum.

1935 Hystrichosphaeropsis Deflandre, p. 232.

1937 Hystrichosphaera subgenus Hystrichosphaeropsis (Deflandre) Deflandre, p. 67.

Remarks. Eisenack (1963b, p. 118) retained Hystrichosphaeropsis at generic rank. Fensome et al. (2009, p. 38) provided a synopsis that allows for the inclusion of circumcavate forms in Hystrichosphaeropsis.

\section{Hystrichosphaeropsis perforata Schiøler 1993}

(Plate 9, fig. 4)

1993 Hystrichosphaeropsis perforata Schiøler, p. 106, plate 2, figs 4-8; text-fig. 3.

Age. LO: late Maastrichtian.

Hystrichosphaeropsis quasicribrata (Wetzel 1961) Gocht 1976

(Plate 9, fig. 12)

1961 Triblastula quasicribrata Wetzel, p. 340, plate 2, fig. 3 .

1976 Hystrichosphaeropsis quasicribrata (Wetzel) Gocht, p. 322.

Age. LO: late Maastrichtian. 


\section{Genus Hystrichostrogylon Agelopoulos 1964}

Type. Agelopoulos 1967, text-figs 1, 2, as Hystrichostrogylon membraniphorum.

1964 Hystrichostrogylon Agelopoulos, p. 673, 674.

\section{Hystrichostrogylon digitus sp. nov.}

(Plate 9, figs 1-3)

Holotype. Plate 9, fig. 3, from a cuttings sample at 2435-2445 m in Rut H-11, GSC type collection no. 137952, sample P39375, slide 01, co-ordinates $15.8 \times$ 105.0, England Finder Q48/1. Length of central body (excluding cavation) $45 \mu \mathrm{m}$, width of central body (excluding cavation) $38 \mu \mathrm{m}$; overall length of cyst 73 $\mu \mathrm{m}$, overall width of cyst $72 \mu \mathrm{m}$. The age determined for the sample from which the holotype was recovered is Lutetian Priabonian.

Etymology. From the Latin digitus (finger), in reference to the long extensions at the process endings. The epithet is a noun in apposition.

Diagnosis. A species of Hystrichostrogylon in which the bi- and trifurcations of the processes constitute long, fine, cylindrical distal branches generally one-third to one half the length of the process stem. The distal branches tend to be perpendicular to the process stem.

Size. Length of central body (excluding cavation) 40-45 $\mu \mathrm{m}$, width of central body (excluding cavation) 33-40 $\mu \mathrm{m}$; overall length of cyst 73-82 $\mu \mathrm{m}$, overall width of cyst $66-79 \mu \mathrm{m} ; 3$ specimens measured.

Age. LO: Bartonian-Priabonian. Not plotted.

Remarks. This species differs from other species of $\mathrm{Hy}$ strichostrogylon in having remarkably long, fine branches at the ends of the processes.

\section{Genus Impagidinium Stover \& Evitt 1978}

Type. Cookson \& Eisenack 1965b, plate 12, figs 5-6, as Leptodinium dispertitum.

1978 Impagidinium Stover \& Evitt, p. 165, 166.

Synopsis. Proximate gonyaulacaceans with the S-type ventral organisation; in dorso-ventral view they are subspheroidal to ellipsoidal. Tabulation clearly defined by sutural septa or thickenings, although sometimes these features are missing between plates bordering the sulcus or the cingulum. Sometimes the septum or thickening between the $3^{\prime}$ and $4^{\prime}$ plates is reduced or absent. Cingulum and sulcus clearly defined. Archaeopyle precingular, with formula $\mathrm{P}_{3^{\prime \prime}}$, operculum free.

Remarks. The inclusion of Impagidinium in the subfamily Gonyaulacoideae by Fensome et al. (1993, p. 92) reflects an appreciation of the commonly triangular shape of the 6" plate. If a separate reflected plate, the $4^{\prime}$ is generally not in contact with the anterior sulcal plate.

\section{Impagidinium victorianum (Cookson \& Eisenack 1965b) Stover \& Evitt 1978}

(Plate 9, figs 9-11, 13, 14)

1965b Leptodinium victorianum Cookson \& Eisenack, p. 123, plate 12, figs 8, 9.

1978 Impagidinium victorianum (Cookson \& Eisenack) - Stover \& Evitt, p. 166.

Age. LO: intra late Maastrichtian.

Remarks. Cookson \& Eisenack (1965b, p. 123) noted that Impagidinium victorianum described from the Late Eocene differs from Impagidinium dispertitum in its "larger size, spherical form, and the constant absence of the transverse dividing between the upper two plates of the ventral field...." Where the anterior ventral side of the specimens in this study can be observed, Impagidinium victorianum also lacks the suture between what are purportedly the upper two plates of the sulcus. However, Labrador Sea specimens of Impagidinium victorianum are generally smaller than the type material, which ranges from 80 to $120 \mu \mathrm{m}$ in length and 80 to $123 \mu \mathrm{m}$ in width. In contrast, the Labrador Sea specimens vary from 60 to $71 \mu \mathrm{m}$ in length and 56 to $80 \mu \mathrm{m}$ in width. Distal and proximal ends of the cingulum are offset by approximately a cingulum width. The sutural features may be ridges or septa but are consistent within an individual specimen. Maximum height of the sutural ridges or septa is $5 \mu \mathrm{m}$. In some specimens the septa are perforated, the perforations aligned in single rows. Whether those forms with perforations should be included in a new species is dependent upon finding more specimens.

An intriguing aspect of the occurrence of Impagidinium victorianum in the Labrador Sea is that its LO is consistently within the Maastrichtian. This may reflect changing environments from deep-water to shallower conditions, but this does not explain the absence 
of the species in deeper water parts of the Palaeogene. One explanation advanced by $M$. Pearce (personal communication 2015) is that Impagidinium victorianum is a warmer-water species that migrated south during cooler climatic conditions. If so, it is odd that it did not migrate back during Paleocene warming, unless opening of the Labrador-Baffin Seaway had already generated a proto-Labrador Current.

\section{Genus Impletosphaeridium Morgenroth 1966a}

Type. Morgenroth 1966a, plate 10, fig. 5, as Impletosphaeridium transfodum.

1966a Impletosphaeridium Morgenroth, p. 32.

1971 Ciliosphaeridium Grigorovich, p. 94.

1984c Laticavodinium Wilson \& Sarjeant in Sarjeant, p. 127.

Remarks. In their remarks on Impletosphaeridium, Fensome et al. (2009, p. 38) agreed with Islam (1993, p. $84,85)$ that the archaeopyle of the paratype of Impletosphaeridium transfodum, the 'type species', is probably apical. But the morphology of the holotype remains uncertain. To quote Fensome et al. (2009, p. 38): "This genus is useful, if of dubious status, since it serves as a repository for chorate forms whose general morphology accords with a gonyaulacacean dinoflagellate affinity, but whose archaeopyle is uncertain."

\section{Impletosphaeridium apodastum sp. nov.}

(Plate 9, figs 5-8)

Holotype. Plate 9, fig. 5, from a cuttings sample at 4565$4575 \mathrm{~m}$ in Hekja O-71, GSC type collection no. 137903, sample P18737, slide 01, co-ordinates $13.3 \times$ 108.0, England Finder N37/3. Central body length 30 $\mu \mathrm{m}$, width $26 \mu \mathrm{m}$; length of processes up to $17 \mu \mathrm{m}$, width less than $1 \mu \mathrm{m}$. The age determined for the sample from which the holotype was recovered is late Danian.

Etymology. The epithet is from the Greek apodastos, meaning separated or apportioned, in reference to the bifurcations of the processes distally.

Diagnosis. A species of Impletosphaeridium with solid delicate processes that divide distally into two relatively long branches. The branches are bifurcate at the tips and usually curve back towards the central body.

Description. This species has a rounded, small central body that is granulate. Distally, the solid delicate pro- cesses divide into two, relatively long branches, each of which is bifurcate at its tip. These distal branches usually curve back towards the central body. The initial bifurcations are generally one-quarter to one-third as long as the main stem of the process but can be as much as a half or as little as a quarter the length. There are about 50 processes per specimen.

Size. Central body length $20-33 \mu \mathrm{m}$, width $18-27 \mu \mathrm{m}$, length of processes $10-18 \mu \mathrm{m}$; six specimens measured.

Age. LO: Selandian.

Remarks. Impletosphaeridium apodastum is characterised by the high number of processes and their distinctive distal extremities, which branch. Tips of the two branches are usually bifid. Occasional processes have three branches. Because of the unknown nature of the archaeopyle, this species is included in Impletosphaeridium.

\section{Genus Isabelidinium Lentin \& Williams 1977b}

Type. Cookson \& Eisenack 1958, plate 4, fig. 10, as Deflandrea korojonensis.

1976 Isabelia Lentin \& Williams, p. 56 (name illegitimate).

1977b Isabelidinium Lentin \& Williams, p. 167.

2009 Isabelidinium Lentin \& Williams - emend. Fensome et al., p. 39.

Remarks. In recent decades, there has been much debate about the definition of Isabelidinium and similar genera such as Manumiella and Chatangiella, all of which have an isodeltaform, isothetaform and/or isoomegaform 2a plate whose partial or complete detachment forms the archaeopyle. Species now included in Chatangiella and Isabelidinium can have an isodelataform, isothetaform or iso-omegaform 2a plate, but Manumiella almost always has an isodeltaform 2a plate. Much confusion remains regarding generic circumscriptions, but a resolution as to how these should be dealt with is beyond the scope of the present study. In our view, generic distinctions should be based mainly on variations in the shape and dimensions of the hexa 2a plate and secondarily on other expressions of tabulation such as the cingulum and on the ornamentation.

Chatangiella is clearly distinguished from Isabelidinium by its partite cingulum. Fensome et al. (2009) emended Manumiella, restricting it to forms with one symmetrically disposed antapical prominence. However, the antapex of the holotype of the type of the genus, 
Manumiella (originally Broomea) seelandica (Lange 1969, plate 3, fig. 3), is partly obscured so that its precise morphology cannot be determined; and the paratype (Lange 1969, plate 2, fig. 10) clearly has two protuberances. Thorn et al. (2009) emended the diagnosis of Manumiella to allow for inclusion of a mesophragm, which we would consider a non-diagnostic feature at generic rank. However, these authors did indicate that Manumiella was distinctive in being circumcavate, with Isabelidinium being bicavate. For further comparisons, see under Alterbidinium.

\section{Isabelidinium cooksoniae (Alberti 1959) Lentin \& Williams 1977b}

1959 Deflandrea cooksoniae Alberti, p. 97, plate 9, figs 1-6.

$1961 \mathrm{~b}$ Isabelidinium belfastense Cookson \& Eisenack, p. 71, plate 11, figs 4-6.

1967 Australiella cooksoniae (Alberti) Vozzhennikova, p. 132.

1976 Isabelia cooksoniae (Alberti) - Lentin \& Williams, p. 57.

1976 Isabelia belfastensis (Cookson \& Eisenack) Lentin \& Williams, p. 57.

1977b Isabelidinium cooksoniae (Alberti) - Lentin \& Williams, p. 167.

1977b Isabelidinium belfastense (Cookson \& Eisenack) - Lentin \& Williams, p. 167.

1992 Isabelidinium bujakii Marheinecke, p. 86, 87, plate 18, figs 1-3; text-fig. 16.

Age. LO: Maastrichtian.

Remarks. See Fensome et al. (2009, p. 39) for a discussion of this species.

\section{Isabelidinium cretaceum (Cookson 1956) Lentin \& Williams 1977b}

(Plate 9, figs 15, 16)

1956 Deflandrea cretacea Cookson, p. 184, 185, plate 1, figs 1-4 (only).

1976 Isabelia cretacea (Cookson) - Lentin \& Williams, p. 57.

1977b Isabelidinium cretaceum (Cookson) - Lentin \& Williams, p. 167.

1983 Manumiella? cretacea (Cookson) - Bujak \& Davies, p. 161.

Age. LO: Maastrichtian.
Remarks. The holotype of this species (Cookson 1956, plate 1, fig. 1 and Helby et al. 1987, fig. 42L) and some of the other specimens illustrated in the protologue (Cookson (1956, plate 1, figs 2-4) are all bicavate, with an endocyst that is broader than long. This bicavation, together with a general rounding of the apical and antapical regions, are considered here to be characteristic for Isabelidinium cretaceum. However, the presence of a very short horn on two specimens (Cookson 1956, plate 1, figs 3, 4), neither of which is the holotype, does not exclude their retention in this species. This species is retained in Isabelidinium because it is bicavate (see discussion above under Isabelidinium).

\section{Isabelidinium microarmum (McIntyre 1975)} Lentin \& Williams 1977 b

(Plate 9, fig. 17)

1975 Deflandrea microarma McIntyre, p. 65, plate 1 , figs $5-8$.

1976 Isabelia microarma (McIntyre) - Lentin \& Williams, p. 58.

1977b Isabelidinium microarmum (McIntyre) Lentin \& Williams, p. 168.

Age. LO: early Campanian.

Remarks. The holotype of Isabelidinium microarmum (McIntyre 1975, plate 1, figs 5, 6) has a deltaform archaeopyle as do all the other specimens (McIntyre 1975 , plate 1 , figs $6-8$ ).

\section{Genus Kiokansium Stover \& Evitt 1978}

Type. Tasch et al. 1964, plate 3, fig. 8, as Hystrichosphaeridium unituberculatum.

1978 Kiokansium Stover \& Evitt, p. 167.

1979 Bacchidinium Davey, p. 555.

Remarks. Characteristic features of Kiokansium are the precingular archaeopyle, which is formed from the loss of plates 3 " and $4{ }^{\prime \prime}$, and the dirigate to cauliflorate distal terminations of the numerous solid processes.

\section{Kiokansium williamsii Singh 1983}

1983 Kiokansium williamsii Singh, p. 150, plate 54, figs 3-6.

Age. LO: Cenomanian. 


\section{Genus Kleithriasphaeridium Davey 1974}

Type. Davey 1974, plate 5, figs 1, 2, text-fig. 3, as Kleithriasphaeridium corrugatum.

1974 Kleithriasphaeridium Davey, p. 55, 56.

1976 Diversispinosa Benson, p. 184.

Age. LO: Coniacian.

Remarks. Fensome et al. (2009, p. 40) emended the diagnosis of Kleithriasphaeridium to include forms with mesotabular, tubular processes that are open or closed distally and "to circumscribe forms with a combination precingular-apical archaeopyle, a type of opening that occurs as an intraspecific variant of some species." These authors also stressed that Kleithriasphaeridium does not have fibrous processes, thus differentiating it from Cordosphaeridium.

\section{Kleithriasphaeridium mantellii (Davey \& Williams 1966a) comb. nov.}

(Plate 9, fig. 18)

\section{6a Hystrichosphaeridium mantellii Davey \& Williams, p. 66, plate 6, fig. 6 . \\ 1973 Florentinia mantellii (Davey \& Williams) - Davey \& Verdier, p. 191.}

Age. LO: Coniacian.

Remarks. Davey \& Williams (1966a, p. 66) stated that "The periphragm of processes [is] slightly fibrous." On the same page they further noted that "... the periphragm of the central body appears to be fairly heavily granular but on closer examination the granules apparently result from a fine reticulation" and that "An apical archaeopyle appears always to be present." Davey \& Verdier (1973, plate 4, figs 1, 3) re-illustrated the holotype of Kleithriasphaeridium (as Florentinia) mantellii and concluded that the archaeopyle is precingular, resulting from the loss of the $3^{\prime \prime}$ plate. Although the processes may be slightly fibrous, it is not obvious in the photographs. Thus the characteristic feature of the species appears to be the ornamentation of the main body. Fensome \& Williams (2005, p. 48) noted that Florentinia includes "forms with simple tubular processes such as Florentinia aculeata and Florentinia cooksoniae, as well as more 'classic' Florentinia types, such as Florentinia laciniata and Florentinia ferox, with more complicated processes." They recommended that taxa with simple tubular processes and precingular rather than combina- tion archaeopyles, such as Florentinia cooksoniae, should be transferred to Kleithriasphaeridium. Thus the new combination Kleithriasphaeridium mantellii is proposed here.

\section{Genus Laciniadinium McIntyre 1975}

Type. McIntyre 1975, plate 4, figs 12, 13, as Laciniadinium orbiculatum.

1975 Laciniadinium McIntyre, p. 70.

1984 Sinocysta He Chengquan, p. 769, 773.

Synopsis. A proximate peridiniacean (palaeoperidinioidean) cyst that is subspherical to biconical and compressed dorso-laterally; when biconical, single horns are developed at the apical and antapical poles. Acavate. Autophragm smooth or ornamented with granules or echinae. Cingulum indicated by low ridges. Archaeopyle combination intercalary-precingular, with formula $\mathrm{IP}_{\left(1-3 \mathrm{a}+3-5^{\prime \prime}\right)}$, operculum simple, attached along the anterior margin of the cingulum.

Remarks. Laciniadinium differs from Palaeoperidinium in having one rather than two antapical horns, and an archaeopyle involving intercalary and precingular plates only.

\section{Laciniadinium arcticum (Manum \& Cookson 1964) Lentin \& Williams 1980}

(Plate 9, figs 19, 20)

1964 Diconodinium arcticum Manum \& Cookson, p. 18,19 , plate 6 , figs $1-4$.

1980 Laciniadinium arcticum (Manum \& Cookson) - Lentin \& Williams, p. 41.

1986 Laciniadinium williamsii Ioannides, p. 28, plate 10, figs 1-6; plate 11, fig. 5.

Age. LO: late Maastrichtian.

Remarks. In their description of Laciniadinium (as Diconodinium) arcticum, Manum \& Cookson (1964) stated that the autophragm was ornamented with minute granules up to $0.5 \mu \mathrm{m}$ in diameter. The size range of the species was: length $50-73 \mu \mathrm{m}$, breadth 32 $53 \mu \mathrm{m}$. Ioannides (1986) erected the species Laciniadinium williamsii, which can have a smooth to finely ornamented autophragm; Laciniadinium williamsii varies from 39 to $54 \mu \mathrm{m}$ in length and 31 to $43 \mu \mathrm{m}$ in width. Unfortunately, Ioannides (1986) did not compare Laciniadinium williamsii to Laciniadinium arcti- 
cum, although he did differentiate it from Laciniadinium orbiculatum McIntyre 1975 and Laciniadinium biconiculum McIntyre 1975. The only difference that we can determine for separating Laciniadinium arcticum and Laciniadinium williamsii is on the size, but this overlaps as demonstrated above. Accordingly, we herein consider Laciniadinium williamsii to be a taxonomic junior synonym of Laciniadinium arcticum.

\section{Genus Lentinia Bujak in Bujak et al. 1980}

Type. Bujak et al. 1980, plate 18, figs 7-9, text-fig. $18 \mathrm{~A}-\mathrm{F}$, as Lentinia serrata.

1980 Lentinia Bujak in Bujak et al., p. 69.

Remarks. Fensome et al. (2009, p. 42) provided a comprehensive synopsis for Lentinia that includes reference to the large 2a isodeltaform archaeopyle, which dominates the dorsal epicystal area of the pericyst.

\section{Lentinia serrata Bujak in Bujak et al. 1980}

(Plate 10, fig. 9)

1980 Lentinia serrata Bujak in Bujak et al., p. 71, 72, plate 18, figs 7-12; text-figs 18A-F, 19.

Age. LO: latest Priabonian.

\section{Genus Licracysta Fensome et al. 2007}

Type. Fensome et al. 2007, plate 4, figs 9-12, as Licracysta corymbus.

\section{Licracysta Fensome et al., p. 400, 402.}

Remarks. Licracysta is an areoligeracean cyst with nontabular to penitabular processes, many dolabrate to moderately licrate, that are absent from the dorsoventral region. In Glaphyrocysta, the processes are not licrate or dolobrate distally. Also, processes tend to be longer relative to the size of the central body than in Licracysta. A synopsis for Licracysta is provided by Fensome et al. (2009, p. 42).

\section{Licracysta corymbus Fensome et al. 2007}

(Plate 10, fig. 16)

2007 Licracysta corymbus Fensome et al., p. 402, 404, 406, 408; plate 4, figs 5, 6, 9-20; plate 5, figs 1-8, 12, 16, 20.

Age. LO: Rupelian.
Licracysta? semicirculata (Morgenroth 1966b)

Fensome et al. 2007

1966b Cyclonephelium semicirculatum Morgenroth, p. 9, 10, plate 2, figs 3, 4 .

1978 Areoligera semicirculata (Morgenroth) - Stover \& Evitt, p. 18.

2007 Licracysta? semicirculata (Morgenroth) - Fensome et al., p. 408.

Age. LO: latest Rupelian.

Remarks. The distribution of the process complexes in Licracysta? semicirculata is reminiscent of the Late Cretaceous forms of Areoligera, in which the midventral surface lacks ornamentation, ventral processes being restricted to ambital linear complexes.

\section{Genus Lingulodinium Wall 1967}

Type. Deflandre \& Cookson 1955, plate 9, fig. 6, as Hystrichosphaeridium machaerophorum.

1967 Lingulodinium Wall, p. 109.

Synopsis. A chorate gonyaulacacean (cribroperidinioid) cyst with a subspherical central body. Acavate. The central body is smooth or ornamented with features of low relief and bears numerous simple, hollow, apparently nontabular processes that are variable in length and distal ending. Archaeopyle precingular, resulting from loss of a variable number of precingular plates (one to five), or epicystal. When the archaeopyle is precingular, the opercular pieces are usually free and separate.

Remarks. We do not know if the variation in archaeopyle development among specimens of Lingulodinium bears any relationship to age or palaeoenvironment.

\section{Lingulodinium funginum (Morgenroth 1966a) Islam 1983a}

(Plate 10, figs 1, 2)

1966a Baltisphaeridium funginum Morgenroth, p. 17,18 , plate 3 , figs 7,8 .

1983a Lingulodinium funginum (Morgenroth) Islam, p. 341.

Age. Peak of Lingulodinium spp. inconsistent within Eocene - it probably has greater palaeoenvironmental than biostratigraphic significance. 
Remarks. According to Morgenroth (1966a), Lingulodinium funginum is characterised by having a variable number of processes that are distally bulbose, in contrast to species such as Lingulodinium machaerophorum that have acuminate process endings. Specimens of Lingulodinium with bulbose process endings are common in some samples from Labrador Margin wells and these are included here in Lingulodinium funginum. However, there is a caveat. Kokinos \& Anderson (1995), in laboratory experiments, noted that the length and nature of the processes of resting cysts of the extant Lingulodinium polyedrum show considerable variation. The processes of the cysts, more familiarly known to palynologists as Lingulodinium machaerophorum, could be distally acuminate, bulbose, smooth or with small granules or spines; process length could vary up to a maximum of 10-12 $\mu \mathrm{m}$. Based on their findings, Kokinos \& Anderson (1995) considered Lingulodinium funginum, Lingulodinium sadoense and Lingulodinium brevispinosum to be taxonomic junior synonyms of Lingulodinium machaerophorum. Because morphological types included here in Lingulodinium funginum occur only in the Eocene in the study material, we propose to retain the species as defined in Morgenroth (1966a) and prefer to avoid the use of infraspecific ranks (e.g. variety). Retention may also provide useful information on palaeoenvironments.

\section{Lingulodinium machaerophorum (Deflandre \& Cookson 1955) Wall 1967}

(Plate 10, figs 3, 4)

1955 Hystrichosphaeridium machaerophorum Deflandre \& Cookson, p. 274, plate 9, figs 4, 8 .

1961 Baltisphaeridium machaerophorum (Deflandre \& Cookson) - Gerlach, p. 191, 192.

1966 Cleistosphaeridium machaerophorum (Deflandre \& Cookson) - Davey et al., p. 170; combination not validly published.

1967 Lingulodinium machaerophorum (Deflandre \& Cookson) - Wall, p. 109.

Age. LO not confirmed in the study area, but globally the species extends to the present day.

\section{Genus Nyktericysta Bint 1986}

Type. Bint 1986, plate 4, figs 1, 2, 5, 6, text-fig. 3A, B, as Nyktericysta davisii.

1986 Nyktericysta Bint, p. 148, 149.

1986 Balmula Bint, p. 158.
1999 Quantouendinium Mao Shaozhi et al., p. 155, 156.

Remarks. Fensome et al. (2009, p. 46) emended the generic diagnosis of Nyktericysta and considered the two wall layers to be the endophragm and ectophragm, to better facilitate comparison with closely similar genera. The ectophragm is finely perforate. According to the emendation, Nyktericysta always has one apical and two antapical horns. In addition, one or two lateral equatorial horns commonly occur, and these may have preand postcingular extensions. The archaeopyle is apical, with the formula $A_{\left(1-4^{\prime}\right)}$ and the operculum usually remains attached. Fensome et al. (2009, p. 46) noted that Vesperopsis differs from Nyktericysta in not having an ectophragm, and that Endoceratium and Pseudoceratium differ in having only an apical, postcingular and antapical horn rather than two antapical horns.

Mao Shaozhi et al. (1999, p. 156) differentiated Quantouendinium from Nyktericysta Bint 1986 and Vesperopsis Bint 1986 on the number and nature of the horns. Fensome et al. (2009, p. 46) in their emendation of Nyktericysta stated that it always has two antapical horns and commonly can have one or two lateral, equatorial horns. This indicates that the main distinction between Quantouendinium and Nyktericysta is that the former has one postcingular horn. However, from Mao Shaozhi et al. (1999, fig. 4), the location of both posterior horns appears to be antapical. We thus consider Quantouendinium to be a taxonomic junior synonym of Nyktericysta.

\section{Nyktericysta davisii Bint 1986}

(Plate 10, figs 5, 6)

1986 Nyktericysta davisii Bint, p. 149, 150, 152, 153 , plate 4 , figs $1-12$; plate 8 , figs $1-6$; textfigs $3 \mathrm{~A}-\mathrm{C}, 4 \mathrm{~A}, \mathrm{~B}, 10 \mathrm{~A}, \mathrm{~B}$.

Age. LO: late Albian.

Remarks. Nyktericysta davisii is characterised by the presence of five horns, of which the two lateral equatorial have pre- and postcingular extensions. The ectophragm is perforate. Tabulation may be indicated by low sutural ridges.

Nyktericysta dictyophora He Chengquan et al. 1992 (Plate 10, figs 7, 8) 
1992 Nyktericysta dictyophora He Chengquan et al., p. 184, 190, 191, plate 1, figs 1-9.

1992 Nyktericysta dictyophora subsp. circularis $\mathrm{He}$ Chengquan et al., p. 185, 191, plate 1, figs 7-9.

1992 Nyktericysta fusiformis $\mathrm{He}$ Chengquan et al., p. 185 , 191, 192, plate 1, fig. 16; plate 2, figs 1-3.

1999 Quantouendinium dictyophorum (He Chengquan et al.) - Mao Shaozhi et al., p. 156.

Age. LO: Cenomanian.

Remarks. Mao Shaozhi et al. (1999, p. 157) considered Nyktericysta dictyophora subsp. circularis to be a junior synonym of Quantouendinium dictyophorum (that is, with the autonym). They also considered Nyktericysta fusiformis to be taxonomic junior synonyms of this species.

\section{Nyktericysta tripenta (Bint 1986) Fensome et al. 2009}

(Plate 10, figs 11, 12)

1986 Balmula tripenta Bint, p. 158, 160, plate 6, figs 9-17; plate 7, fig. 8; text-fig. 6A, B.

2009 Nyktericysta tripenta (Bint) - Fensome et al., p. 46.

Age. LO: Albian.

Remarks. Fensome et al. (2009, p. 46) noted that Nyktericysta tripenta has a coarse autophragmal reticulum, with muri being up to $10 \mu \mathrm{m}$ wide.

\section{Genus Odontochitina Deflandre 1937}

Type. Deflandre 1937, plate 18 (also labelled plate 15), fig. 8, as Odontochitina silicorum.

\section{Odontochitina Deflandre, p. 94.}

Remarks. The synopsis provided for Odontochitina by Fensome et al. (2009, p. 46) does not allow for the inclusion of forms with abbreviated horns.

\section{Odontochitina ancala Bint 1986}

(Plate 10, fig. 14)

1986 Odontochitina ancala Bint, p. 139, 140, plate 1, figs 2-8; plate 7, figs 1, 2; text-fig. 2A.

Age. LO: Cenomanian.
Remarks. According to Bint (1986, p. 140), "Odontochitina ancala differs from $O$. operculata by having an elbow and cingular notch in the right lateral horn, localised perforations about midway along the horns, and an elongate ventral extension of the antapical pericoel."

\section{Odontochitina costata Alberti 1961}

(Plate 10, fig. 15)

1961 Odontochitina costata Alberti, p. 31, plate 6, figs 10-13.

1962 Odontochitina striatoperforata Cookson \& Eisenack, p. 490, plate 3, figs 14-19.

Age. LO: latest Campanian.

Remarks. Odontochitina costata was emended by Clarke \& Verdier $(1967$, p. 58, 59), who considered Odontochitina striatoperforata to be intergradational with, and a taxonomic junior synonym of, Odontochitina costata.

\section{Odontochitina porifera Cookson 1956}

(Plate 10, fig. 13)

1956 Odontochitina porifera Cookson, p. 188, plate 1, fig. 7.

Age. LO: Santonian.

Remarks. In the Scotian Margin wells, the LO of Odontochitina porifera is also Santonian (Fensome et al. 2009, p. 47).

Genus Oligosphaeridium Davey \& Williams 1966a Type. White 1842 , plate 4, fig. 11 , as Xanthidium tubiferum var. complex.

1966a Oligosphaeridium Davey \& Williams, p. 70, 71.

Remarks. In their synopsis for Oligosphaeridium, Fensome et al. (2009, p. 47) stated: "processes more or less equal in size and general shape." There are two exceptions, the first and fourth apical $\left(1^{\prime}, 4^{\prime}\right)$ are generally slender compared to the other apicals, although all the apicals tend to be slender.

\section{Oligosphaeridium albertense (Pocock 1962) Davey} \& Williams 1969

(Plate 10, fig. 17) 
1962 Hystrichosphaeridium albertense Pocock, p. 82, plate 15, figs 226, 227.

1962 Hystrichosphaeridium irregulare Pocock, p. 82, plate 15, figs 228, 229.

1964 Hystrichosphaeridium coelenteratum Tasch in Tasch et al., p. 195, plate 2, fig. 11.

1964 Hystrichosphaeridium dispare Tasch in Tasch et al., p. 195, plate 2, fig. 8

1964 Hystrichosphaeridium reniforme Tasch in Tasch et al., p. 193, plate 2, fig. 6.

1969 Oligosphaeridium albertense (Pocock) - Davey \& Williams, p. 5.

Age. LO: early Cenomanian.

Remarks. In his emendation of Oligosphaeridium albertense, Brideaux (1977, p. 27, 28) described the processes as hollow, flared to tubiform, with the open distal margins being "variably secate, occasionally aculeate or serrate; the distal third of some processes variably fenestrate ...." Jansonius (1986, p. 213) described the holotype of Oligosphaeridium albertense, which he re-illustrated (his plate 4, figs 4, 5), as having processes that were proximally nearly cylindrical but widened, and were strongly flared distally. The distal margins of the processes were "occasionally scalloped, carrying numerous coarse to fine, slender spinules." Jansonius (1986) considered Hystrichosphaeridium (as Oligosphaeridium) irregulare to be a taxonomic junior synonym of Oligosphaeridium albertense. Stover \& Evitt $(1978$, p. 68, 69) regarded Hystrichosphaeridium (as Oligosphaeridium) coelenteratum, Hystrichosphaeridium (as Oligosphaeridium) dispare and Hystrichosphaeridium (as Oligosphaeridium) reniforme as taxonomic junior synonyms of Oligosphaeridium irregulare. Thus, by implication, Oligosphaeridium coelenteratum, Oligosphaeridium dispare and Oligosphaeridium reniforme are all taxonomic junior synonyms of Oligosphaeridium albertense.

\section{Oligosphaeridium pulcherrimum (Deflandre \& Cookson 1955) Davey \& Williams 1966a}

(Plate 10, figs 18, 19)

1955 Hystrichosphaeridium pulcherrimum Deflandre \& Cookson, p. 270, 271, plate 1, fig. 8; textfigs 21, 22.

1966a Oligosphaeridium pulcherrimum (Deflandre \& Cookson) - Davey \& Williams, p. 75, 76.

Age. LO: regional - Santonian; LAD - Danian. Not plotted.
Remarks. Included here in Oligosphaeridium pulcherrimum are those forms that have a mixture of perforated and unperforated processes. Oligosphaeridium complex has no perforated processes.

\section{Oligosphaeridium totum Brideaux 1971}

(Plate 10, fig. 20)

1971 Oligosphaeridium totum Brideaux, p. 88, 89, plate 25, figs 53-55, 57.

1971 Oligosphaeridium diastema Singh, p. 337, plate 55, figs 4, 5; plate 56, figs 1, 2.

Age. LO: early Cenomanian.

Remarks. Based on nannofossil control, Fensome et al. (2009) considered the last occurrence for Oligosphaeridium totum to be in the early Cenomanian.

\section{Genus Operculodinium Wall 1967}

Type. Deflandre \& Cookson 1955, plate 8, figs 3, 4, as Hystrichosphaeridium centrocarpum.

\section{Operculodinium Wall, p. 110, 111.}

Remarks. Operculodinium is a chorate gonyaulacacean (criboperidinioidean) cyst with a spheroidal to slightly ovoidal central body with a reticulate wall. The central body bears numerous nontabular to contabular processes. Processes are generally solid, of the same size in individual species and distally bifid to aculeate. The archaeopyle is precingular, with the formula $\mathrm{P}_{3^{\prime \prime}}$; the operculum is free. Fensome et al. (2009, p. 48) discussed the differences between Operculodinium and the closely similar genus Exochosphaeridium.

\section{Operculodinium centrocarpum (Deflandre \& Cookson 1955) Wall 1967}

(Plate 11, figs 5, 6)

1955 Hystrichosphaeridium centrocarpum Deflandre \& Cookson, p. 272, 273, plate 8, figs 3, 4.

1961 Baltisphaeridium centrocarpum (Deflandre \& Cookson) - Gerlach, p. 192,193.

1965 Cordosphaeridium centrocarpum (Deflandre \& Cookson) - de Coninck, p. 33.

1966a Cordosphaeridium tiara subsp. centrocarpum (Deflandre \& Cookson) - Morgenroth, p. 26.

1967 Operculodinium centrocarpum (Deflandre \& Cookson) - Wall, p. 111. 
1969 Cordosphaeridium? microtriainum subsp. centrocarpum (Deflandre \& Cookson) - de Coninck, p. 32.

1978 Cleistosphaeridium centrocarpum (Deflandre \& Cookson) - Jiabo, p. 61.

1983 Operculodinium echigoense Matsuoka, p. 126, plate 7 , figs $1,2 \mathrm{a}, \mathrm{b}, 3-5,8$.

1987 Operculodinium? echigoense Matsuoka Mudie, p. 804.

Age. LO: Tortonian.

\section{Genus Palaeocystodinium Alberti 1961}

Type. Alberti 1961, plate 7, fig. 12, as Palaeocystodinium golzowense.

1961 Palaeocystodinium Alberti, p. 20.

1963 Cystodiniopsis Vozzhennikova, p. 185.

Remarks. In their emendation of Palaeocystodinium, Fensome et al. (2009, p. 48) stated that they are "Peridiniacean (deflandreoid) cysts that are fusiform in shape, with single prominent pointed horns apically and antapically; the horns are generally long and there may be a short accessory antapical horn." Fensome et al. (2009) differentiated Palaeocystodinium from the genus Svalbardella Manum 1960 on the nature of the horns distally; the latter has bluntly rounded apical and antapical horns.

\section{Palaeocystodinium bulliforme Ioannides 1986}

(Plate 11, figs 1, 2)

1986 Palaeocystodinium bulliforme Ioannides, p. 31, plate 17 , figs $2-5$.

Age. LO: Selandian.

Palaeocystodinium golzowense Alberti 1961

(Plate 10, fig. 10)

1961 Palaeocystodinium golzowense Alberti, p. 20, plate 7, figs 10-12; plate 12, fig. 16.

Age. LO: late Tortonian (Late Miocene).

\section{Palaeocystodinium teespinosum Fensome et al. 2009}

(Plate 11, fig. 3)

2009 Palaeocystodinium teespinosum Fensome et al., p. 50 , plate 8 , figs $\mathrm{m}-\mathrm{p}$.
Age. LO: early Rupelian.

Remarks. Palaeocystodinium teespinosum differs from Palaeocystodinium golzowense in having delicate $\mathrm{T}$ shaped spinelets that are about $2 \mu \mathrm{m}$ long and are especially common on the apical and antapical horns.

\section{Genus Palaeohystrichophora Deflandre 1935}

Type. Deflandre 1935, plate 8, fig. 4, as Palaeohystrichophora infusorioides.

\section{Palaeohystrichophora Deflandre, p. 230.}

Remarks. In their remarks for this genus, Fensome et al. (2009, p. 50) compared Palaeohystrichophora to Subtilisphaera Jain \& Millepied 1973. Both genera lack an obvious archaeopyle, but Harker (1979, p. 374, fig. 1) observed a combination archaeopyle with the formula $3 \mathrm{I} \mathrm{P}_{\left(1-3 \mathrm{a}+3-5^{\prime \prime}\right)}$ in Palaeohystrichophora infusorioides; according to Harker, the operculum remains attached along the posterior or cingular margin. Bujak \& Davies (1983, p. 62, text-fig. 4) observed an archaeopyle, which they termed the transverse archaeopyle, in some species assigned to Subtilisphaera. This archaeopyle resulted from the development of sutures between the apicals and three anterior intercalary plates and between the anterior lateral margins of the intercalaries. The major observable difference between the two genera is the presence of processes on the pericyst of Palaeohystrichophora. Forms with processes that are presently included in Subtilisphaera should probably be included in Palaeohystrichophora.

\section{Palaeohystrichophora infusorioides Deflandre 1935} (Plate 11, fig. 4)

1935 Palaeohystrichophora infusorioides Deflandre, p. 230, 231, plate 8, fig. 4 .

1943 Palaeohystrichophora paucisetosa Deflandre, p. 507, 508, text-fig. 26.

Age. LO: Campanian.

\section{Genus Palaeoperidinium Deflandre 1934 ex Sarjeant 1967}

Type. Ehrenberg 1838, plate 1, fig. 4, as Peridinium pyrophorum.

1934 Palaeoperidinium Deflandre, p. 968; name not validly published.

1963 Pentagonum Vozzhennikova, p. 183; name not validly published. 
1967 Palaeoperidinium Deflandre ex Sarjeant, p. 246, 247.

1967 Pentagonum Vozzhennikova ex Vozzhennikova, p. 106; name illegitimate.

1970 Astrocysta Davey, p. 359.

Remarks. The synopses of Palaeoperidinium provided by Stover \& Evitt (1978, p. 217) and Fensome et al. (2009, p. 51) are very similar. In their remarks, Fensome et al. (2009) took into account the emendation of Palaeoperidinium by Evitt et al. (1998, p. 46, 48), who noted that the most commonly preserved wall of the cyst is an exophragm, which is unusual in having been formed outside but in contact with the exterior surface of the theca.

\section{Palaeoperidinium pyrophorum (Ehrenberg 1838 ex} Wetzel 1933b) Sarjeant 1967

(Plate 11, figs 7,8)

1838 Peridinium pyrophorum Ehrenberg, plate 1, figs 1, 4; name not validly published.

1933b Peridinium pyrophorum Ehrenberg ex Wetzel, p. $164,165$.

1967 Palaeoperidinium pyrophorum (Ehrenberg ex Wetzel) - Sarjeant, p. 246.

1967 Peridinium basilium Drugg, p. 13, plate 1, figs 9-11; plate 9, fig. 1a, b.

1967 Pentagonum marginatum Vozzhennikova, p. 107, plate 46, figs $1,3,4$, 6; generic name illegitimate.

1967 Pentagonum sibiricum Vozzhennikova, p. 106, 107, plate 46, figs 2, 5 .

1967 Peridinium conicum var. larjakiense Vozzhennikova, p. 71, 72, plate 16, figs 1a, b, 2a, b.

1973 Palaeoperidinium deflandrei Lentin \& Williams, p. 105.

1981 Palaeoperidinium larjakiense (Vozzhennikova) - Lentin \& Williams, p. 210.

Age. LO: Selandian; peak: early Danian.

Remarks. Gocht \& Netzel (1976, p. 403-405) and Evitt et al. $(1998$, p. 48,49$)$ provided comprehensive, concise emendations of Palaeoperidinium pyrophorum, and resolved its relationship to the thecate equivalent.

\section{Genus Palynodinium Gocht 1970}

Type. Gocht 1970, fig. 4, nos 1a-c, as Palynodinium grallator.
1970

Palynodinium Gocht, p. 135, 137, 138, 140.

\section{Palynodinium grallator Gocht 1970}

(Plate 11, figs 9, 10)

1970 Palynodinium grallator Gocht, p. 135, 137, 138, 140, fig. 2a-e; fig. 4, nos 1a-c, 2a, b, 3a, b, 4a, b, 5a, b, 6a, b, 7, 8; fig. 5, nos 1, 2a, b.

Age. LO: latest Maastrichtian.

\section{Genus Petalodinium Williams et al. 2015}

Type. Williams \& Downie 1966b, plate 20, figs 1, 2, as Wetzeliella condylos.

2015 Petalodinium Williams et al., p. 307.

Remarks. Williams et al. (2015) erected the genus Petalodinium for wetzelielloidean dinocysts with a latiepeliform archaeopyle and a pericyst that is smooth or ornamented with features of low relief.

\section{Petalodinium condylos (Williams \& Downie 1966b) Williams et al. 2015}

(Plate 11, figs 11, 12)

1966b Wetzeliella condylos Williams \& Downie, p. 193, 194, plate 20, figs 1, 2.

1976 Rhombodinium condylos (Williams \& Downie) - Lentin \& Williams, p. 128.

1979 Dracodinium condylos (Williams \& Downie) Costa \& Downie, p. 43.

2015 Petalodinium condylos (Williams \& Downie) Williams et al., p. 308.

Age. LO: Ypresian.

Remarks. As Williams et al. (2015) have demonstrated, the holotype of Petalodinium condylos (Williams \& Downie 1966b, plate 20, fig. 1, as Wetzeliella condylos), which is the type of Petalodinium, has a latiepeliform archaeopyle. Apparently related to the latiepeliform archaeopyle is the nature of the apical horn, which in Petalodinium condylos is reduced or absent, the apex being rounded. The pericyst is verrucate to tuberculate. Often, the intratabular ornamentation delineates the tabulation: other verrucae or tubercles are penitabular. Both peri- and endophragm are thick, about $3 \mu \mathrm{m}$. Some specimens observed in the Labrador Margin samples are devoid of ornamentation, but are otherwise identical. 


\section{Genus Phelodinium Stover \& Evitt 1978}

Type. Corradini 1973, plate 28, fig. 3, as Deflandrea pentagonalis.

1978 Phelodinium Stover \& Evitt, p. 117, 118.

Synopsis. A dorso-ventrally compressed, proximate protoperidiniacean (protoperidinioidean) cyst with one apical and two antapical horns. The cyst is pentagonal with convex to concave lateral sides. It is produced into one apical and two antapical horns that can be of variable length, are usually acuminate distally, and may have solid tips. Cornucavate where two wall layers can be discerned. Cingulum sometimes present. Endocyst, where observable, and pericyst smooth or ornamented with features of low relief. Archaeopyle intercalary, with formula $I_{(2 a)}$, the second anterior intercalary plate is deltaform; operculum usually free.

Remarks. The emendation of Phelodinium by Mao Shaozhi \& Norris $(1988$, p. 51, 52) related to the archaeopyle index, given in the original diagnosis as 0.3 to 0.4 by Stover \& Evitt (1978, p. 117). Mao Shaozhi \& Norris (1988) expanded the index to between 0.3 and 0.6; these authors also classified the archaeopyle as standard hexa 2a. One difficulty with Phelodinium is determining if it has one or two wall layers. According to Stover \& Evitt (1978, p. 118) "Phelodinium differs from Lejeunia in being cavate and in having a peridinioid outline with straight to concave sides. Lejeunia has an autophragm only, and its lateral margins are normally convex." That there are two wall layers in Phelodinium is often extremely difficult to discern and the outline of the cyst in the two genera appears to be variable.

\section{Phelodinium kozlowskii (Górka 1963) Lindgren 1984}

(Plate 12, figs 1-3)

1963 Lejeunia kozlowskii Górka, p. 41, plate 5, fig. 4. 1970 Astrocysta kozlowskii (Górka) - Davey, p. 369.

1977 Senegalinium kozlowskii (Górka) - Harland, p. 189.

1984 Phelodinium kozlowskii (Górka) - Lindgren, p. 181.

Age. LO: Danian.

Remarks. Harland (1973, p. 673) and Harker \& Sarjeant (1975, p. 223) considered Phelodinium kozlowskii to be a taxonomic junior synonym of Phelodinium tricuspe. In their emendation of Phelodinium tricuspe, Lejeune-Carpentier \& Sarjeant (1981, p. 20) stated that the "Phragma [is] apparently composed of a single layer (autophragm)." These authors also observed that in the holotype of Phelodinium (as Lejeunecysta) tricuspe only one wall layer could be discerned: this observation explains why these authors accepted the transfer of the species to Lejeunecysta by Artzner \& Dörhöfer (1978). Lindgren (1984, p. 181-183) recorded two wall layers in Phelodinium kozlowskii, with the endophragm being closely appressed to the periphragm except at the tips of the horns. Some of the specimens of Phelodinium kozlowskii encountered in this study show a similar morphology, which is why the species is retained in Phelodinium and separated from Phelodinium tricuspe; assuming that the holotype of the latter species has a single wall layer, it should be included in Lejeunecysta.

\section{Genus Phthanoperidinium Drugg \& Loeblich Jr. 1967}

Type. Drugg \& Loeblich Jr. 1967, plate 1, fig. 4, as Phthanoperidinium amoenum.

\section{Phthanoperidinium Drugg \& Loeblich Jr.,} p. 182.

Remarks. Fensome et al. (2009, p. 54) provided a comprehensive synopsis of Phthanoperidinium, which included the findings by Edwards \& Bebout (1981, p. 36) and Islam (1982, p. 306) on the variability and complexity of the archaeopyle. Although the variability has not been noted rigorously, if the trend is similar to that in other peridiniaceans, it is probable that the various types have different stratigraphic ranges. This has already been demonstrated in Phthanoperidinium geminatum and Phthanoperidinium regale, whose only difference is in the nature of the archaeopyle.

\section{Phthanoperidinium coreoides (Benedek 1972) Lentin \& Williams 1976 \\ (Plate 11, figs 13, 14)}

1972 Hystrichogonyaulax coreoides Benedek, p. 20, plate 9, fig. 4a-c.

1976 Phthanoperidinium coreoides (Benedek) Lentin \& Williams, p. 76.

1976 Phthanoperidinium tritonium Eaton, p. 299, 300 , plate 17 , figs $2,3,6,7$; text-figs $23 \mathrm{C}$, $24 \mathrm{~A}, \mathrm{~B}$.

Age. LO: Rupelian. 
Remarks. Following Fensome et al. (2009, p. 55), Phthanoperidinium coreoides and Phthanoperidinium comatum are separate species, distinguished on the relative length of the processes. In Phthanoperidinium coreoides, the processes are about one third the diameter of the central body; in Phthanoperidinium comatum, the processes are about one half the diameter of the central body.

\section{Phthanoperidinium levimurum Bujak in Bujak et al. 1980}

(Plate 11, fig. 15)

1980 Phthanoperidinium levimurum Bujak in Bujak et al., p. 74, plate 19, figs 13-16; text-figs 20E, 22B.

Age. LO: Priabonian.

Remarks. Phthanoperidinium levimurum is characterised by having the tabulation delineated by membranes, which are usually smooth distally but may sometimes be denticulate.

\section{Phthanoperidinium multispinum Bujak in Bujak et al. 1980}

(Plate 11, figs 16, 17)

1980

Phthanoperidinium multispinum Bujak in Bujak et al., p. 74, plate 19, figs 17-19; textfig. 20F.

Age. LO: latest Priabonian.

\section{Phthanoperidinium regale Bujak 1994}

(Plate 11, figs 18, 19)

1994 Phthanoperidinium regale Bujak, p. 130, plate 4, figs 4-6.

Age. LO: Lutetian.

Remarks. Phthanoperidinium regale has ornamentation similar to Phthanoperidinium geminatum Bujak in Bujak et al. 1980, but differs in having a combination archaeopyle, with the formula IP $\left(2 \mathrm{a}+4^{\prime \prime}\right)$. Phanoperidinium geminatum has the more usual archaeopyle type for the genus, losing the 2 a plate only. In Phthanoperidinium regale, the operculum is free.
Phthanoperidinium stockmansii (de Coninck 1975) Lentin \& Williams 1977a

(Plate 11, fig. 20)

1975 Peridinium stockmansii de Coninck, p. 97, 98, plate 17, figs 18-37.

1977a Phthanoperidinium stockmansii (de Coninck) - Lentin \& Williams, p. 131.

1976 Phthanoperidinium echinatum Eaton, p. 298, 299, plate 17, figs 8, 9, 12; text-fig. 23B.

1980 Phthanoperidinium? pseudoechinatum Bujak in Bujak et al., p. 75, 76, plate 19, fig. 20; textfig. 20C.

Age. LO: Priabonian.

Remarks. Phthanoperidinium stockmansii has penitabular rows of small processes that distally are clavate. Rows of processes usually occur in parallel pairs, somewhat like railway tracks. De Coninck (1977, p. 40) considered Phthanoperidinium echinatum to be a junior taxonomic synonym of Phthanoperidinium stockmansii. Islam (1982, p. 315) agreed with this synonymy, but mistakenly thought that Phthanoperidinium echinatum was the senior name. Accepting Islam's synonymy of Phthanoperidinium pseudoechinatum with Phthanoperidinium echinatum, the former thus becomes a junior taxonomic synonym of Phthanoperidinium stockmansii.

\section{Genus Piladinium Williams et al. 2015}

Type. Michoux 1988, plate 1, figs 2, 3, as Kisselovia columna.

2015 Piladinium Williams et al., p. 308, 309.

Remarks. Piladinium is a wetzelielloidean genus with a latiepeliform archaeopyle and processes connected by an ectophragmal membrane. For comparison with other wetzelielloidean genera, see Williams et al. (2015).

\section{Piladinium columna (Michoux 1988) Williams et al. 2015}

(Plate 12, figs 5, 6)

1988 Kisselevia columna Michoux, p. 28, 30, plate 1, figs 2, 3, 5, 6; plate 2, figs 3-5; text-fig. 7A, B.

1989 Charlesdowniea columna (Michoux) - Lentin \& Vozzhennikova, p. 74.

2015 Piladinium columna (Michoux) - Williams et al., p. 309. 
Age. LO: Ypresian.

Remarks. Several of the observed Labrador Margin specimens of Piladinium columna have reduced numbers of processes on the mid-ventral and mid-dorsal regions. The morphology of these specimens is thus approaching that of Piladinium edwardsii.

\section{Piladinium edwardsii (Wilson 1967b) Williams et al. 2015}

(Plate 12, figs 7, 8)

1967b Wetzeliella edwardsii Wilson, p. 477, figs 8, 9.

1978 Kisselevia edwardsii (Wilson) - Stover \& Evitt, p. 111.

1989 Charlesdowniea edwardsii (Wilson) - Lentin \& Vozzhennikovia, p. 227.

2015 Piladinium edwardsii (Wilson) - Williams et al., p. 309.

Age. LO: early Ypresian. Not plotted.

\section{Genus Pseudoceratium Gocht 1957}

Type. Gocht 1957, plate 18, fig. 1, as Pseudoceratium pelliferum.

1957 Pseudoceratium Gocht, p. 166.

1962 Eopseudoceratium Neale \& Sarjeant, p. 446.

1966a Doidyx Sarjeant, p. 205.

Synopsis. A dorso-ventrally compressed, proximate ceratiacean cyst with single apical, postcingular and antapical horns. Wall formed of one or two layers. If two-layered, there can be endophragm and periphragm or endophragm and ectophragm. Tabulation often indicated by ornamentation if present. Ornamentation may be absent or it may be granular or consist of short processes, which may be trabeculate. Cingulum sometimes obvious. Archaeopyle apical, with formula $A_{\left(1-4^{\prime}\right)}$, operculum free; sulcal notch offset to the left.

\section{Pseudoceratium sp.}

(Plate 12, fig. 4)

Remarks. Our specimens of Pseudoceratium differ from Pseudoceratium pelliferum in having longer processes and in generally lacking a lateral horn.

\section{Genus Raphidodinium Deflandre 1936}

Type. Deflandre 1936, plate 10, figs 1, 2, 7, Raphidodinium fucatum.
1936 Raphidodinium Deflandre, p. 184, 185.

Synopsis. Chorate cyst with ovoidal central body and a clearly defined cingulum. The cingulum can subdivide the central body into equal epi- and hypocysts or be anteriorly located, dividing the cyst into a short epicyst and much longer hypocyst. Tabulation marked by membranes or ridges and long, slender processes that are clustered along the cingulum and to a lesser extent in the antapical area. Processes are distally blunt to multifurcate. Archaeopyle indeterminate.

Remarks. Marheinecke (1992, p. 79) considered the archaeopyle of Raphidodinium fucatum subsp. compactum Marheinecke 1992 to be possibly precingular.

\section{Raphidodinium fucatum Deflandre 1936}

(Plate 12, figs 9, 10)

1936 Raphidodinium fucatum Deflandre, p. 185, 186 , plate 10 , figs $1-7$.

Age. LO: Campanian.

Remarks. The unequal sizes of the epi- and hypocysts suggest that Raphidodinium fucatum could be a cladopyxiacean.

\section{Genus Reticulosphaera Matsuoka 1983}

Type. Matsuoka 1983, plate 4, fig. 8, as Reticulatosphaera stellata.

1983 Reticulatosphaera Matsuoka, p. 116.

Reticulatosphaera actinocoronata (Benedek 1972) Bujak \& Matsuoka 1986

(Plate 12, figs 11, 12)

1972 Cleistosphaeridium actinocoronatum Benedek, p. 34, plate 12, fig. 13; text-fig. 12.

1978 Areosphaeridium? actinocoronatum (Benedek) - Stover \& Evitt, p. 20.

1983 Reticulatosphaera stellata Matsuoka, p. 116, 117, plate 4, figs 8-11; text-fig. 10.

1986 Reticulatosphaera actinocoronata (Benedek 1972) - emend. Bujak \& Matsuoka 1986, p. 238.

Age. LO: earliest Zanclian. Not plotted. 
Genus Rhombodinium Gocht 1955 emend.

Williams, Damassa, Fensome \& Guerstein in

Fensome et al. 2009

Type. Gocht 1955, text-fig. 1c, as Rhombodinium draco.

1955 Rhombodinium Gocht, p. 85.

1961 Wetzeliella subgenus Rhombodinium (Gocht) - Alberti, p. 9.

2009 Rhombodinium Gocht 1955 emend. Williams, Damassa, Fensome \& Guerstein in Fensome et al., p. 57.

Remarks. We fully concur with the emendation in Fensome et al. (2009), which emphasises the generic significance of the archaeopyle. According to the emended diagnosis, species of Rhombodinium must have a soleiform archaeopyle, which always has an operculum that is attached apically. Rhombodinium was retained at generic rank by Lentin \& Williams (1977a, p. 139).

\section{Rhombodinium draco Gocht 1955}

(Plate 12, figs 13, 14)

1955 Rhombodinium draco Gocht, p. 86, text-fig. $1 \mathrm{a}-\mathrm{c}$.

1961 Wetzeliella subgenus Rhombodinium draco (Gocht) - Alberti, p. 8.

Age. LO: Priabonian.

Remarks. Vozzhennikova (1967, p. 168) retained this taxon in Rhombodinium.

\section{Rhombodinium porosum Bujak 1979}

1979 Rhombodinium porosum Bujak, p. 314, 315, plate 1 , figs 3, 5-8; plate 2, fig. 11 ; text-fig. $8 \mathrm{C}$.

Age. LO: Bartonian.

Genus Rottnestia Cookson \& Eisenack 1961a

Type. Eisenack 1954, plate 9, fig. 5, as Hystrichosphaera borussica.

1961a Rottnestia Cookson \& Eisenack, p. 40, 42.

\section{Rottnestia borussica (Eisenack 1954) Cookson \& Eisenack 1961a}

(Plate 13, fig. 1)
1954 Hystrichosphaera borussica Eisenack, p. 62, plate 9, figs 5a, b, 6, 7.

1961a Rottnestia borussica (Eisenack) - Cookson \& Eisenack, p. 42.

1966a Triblastula borussica (Eisenack) - Morgenroth, p. $15,16$.

1966b Hystrichosphaeropsis borussica (Eisenack) Sarjeant, p. 139; combination not validly published.

Age. LO: Lutetian. Not plotted.

\section{Genus Scalenodinium gen. nov.}

Type. Plate 12, fig. 15, as Scalenodinium scalatum.

Etymology. The name is from the Latin scalenus, meaning unequal, uneven, odd, in reference to the unequal variation in apical and antapical development.

Description. Pericoel elongate, with an apical horn that is acuminate to rounded distally and generally a rounded antapex, although the latter may be extended into a short protuberance. When the endocyst is present, the cyst is bicavate. Cingulum present or faintly expressed. Periarchaeopyle intercalary, generally with formula $\mathrm{I}_{2 \mathrm{a}}$, and with a free operculum. The hexa $2 \mathrm{a}$ plate is stenodeltaform. In some specimens, the apparent loss of the apical area (Plate 12, figs 16-19) or of other intercalary plates besides the $2 \mathrm{a}$ (Plate 12, fig. 15) indicates a compound and/or combination archaeopyle.

Remarks. Scalenodinium differs from Isabelidinium in having a stenodeltaform, rather than a lati- to iso-omegaform 2a plate. Palaeocystodinium, which like Scalenodinium has a stenodeltaform 2a plate, differs from the latter genus in always having more or less apical and antapical horns and a periarchaeopyle that is always formed from the loss of a single plate, the 2a plate, rather than several plates as in Scalenodinium.

\section{Scalenodinium scalenum sp. nov.}

(Plate 12, figs 15-20)

Holotype. Plate 12, fig. 15, from a cuttings sample at 2135-2145 $\mathrm{m}$ in Gilbert F-53, GSC type collection no. 137916, sample P39484, slide 01, co-ordinates $19.3 \times$ 106.5, England Finder T37/4. Pericyst length $81 \mu \mathrm{m}$, width $31 \mu \mathrm{m}$. The age determined for the sample from which the holotype was recovered is Ypresian. 
Etymology. The name is from the Latin scalenus, meaning unequal, uneven, odd, in reference to the unequal variation in apical and antapical development.

Description. A species of Scalenodinium with an elongate pericoel that has an apex bearing a well-developed, distally acuminate to rounded apical horn and an antapex that is generally rounded, though an antapical protuberance may occasionally be developed. When an endocyst is present, the cyst is bicavate. The pericyst is verrucate to granulate in the mid-dorsal and midventral regions. A cingulum is rarely developed. Both pericyst and endocyst have walls that are, at the most, 1 $\mu \mathrm{m}$ thick. Periarchaeopyle intercalary, generally with formula $\mathrm{I}_{2 \mathrm{a}}$, operculum free. The hexa 2 a plate is stenodeltaform. In some specimens, the apparent loss of the apical area (Plate 12, figs 16-19) or of other intercalary plates besides the 2a (Plate 12, fig. 15) indicates a compound and/or combination archaeopyle.

Size. Pericyst length $77-86 \mu \mathrm{m}$, pericyst width $38-56$ $\mu \mathrm{m}$, apical horn length $18-27 \mu \mathrm{m}$, apical horn maximum breadth 11-14 $\mu \mathrm{m}$.

Age. LO: Ypresian.

Remarks. Scalenodinium scalenum shows some variation in the antapical region: although generally rounded antapically, some specimens have a prominent antapical horn that is more or less centrally located. The pericyst invariably has folds running across its surface. It is difficult to be specific about the nature of the archaeopyle since there is a common tendency for the apical polar area to break up. Thus this breakup could be interpreted to denote a compound or combination archaeopyle. Width and shape of the distal terminations of the horn or horns vary considerably.

Genus Schematophora Deflandre \& Cookson 1955 Type. Deflandre \& Cookson 1955, plate 6, figs 11, 12, as Schematophora speciosa.

1954 Schematophora Deflandre \& Cookson, p. 1237 (name not validly published).

1955 Schematophora Deflandre \& Cookson, p. 262.

Remarks. The synopsis provided by Fensome et al. (2009) covers all the salient points regarding the morphology of Schematophora.

\section{Schematophora speciosa Deflandre \& Cookson} 1955

(Plate 13, fig. 2)

1955 Schematophora speciosa Deflandre \& Cookson, p. 262, 263, plate 6, figs 11-13; plate 7, fig. 11 .

Age. LO: Priabonian.

Genus Senegalinium Jain \& Millepied 1973

Type. Jain \& Millepied 1973, plate 1, figs 1-3, as Senegalinium bicavatum.

\section{Senegalinium Jain \& Millepied, p. 22, 23.}

Synopsis. Peridiniacean (deflandreoid) cysts with a peridinioid, usually elongate pericyst and two antapical horns that are more or less of equal length. Bicavate with a circular to pentagonal endocyst. Pericyst surface smooth or with low ornament, sometimes with cingulum indicated. Periarchaeopyle intercalary, resulting from the loss of the iso- to stenodeltaform deltaform $2 \mathrm{a}$ plate; the operculum commonly remains attached along the posterior margin.

Remarks. Alterbidinium differs from Senegalinium in having two antapical horns that are of unequal length. Since Alterbidinium contains species that may have a combination intercalary-precingular archaeopyle resulting from the loss of the $2 \mathrm{a}$ and $4^{\prime \prime}$ plate, it would not be surprising to find the same variability in Senegalinium.

\section{Senegalinium iterlaaense Nøhr-Hansen \& Heilmann-Clausen 2001}

(Plate 13, figs 3, 4)

2001 Senegalinium iterlaaense Nøhr-Hansen \& Heilmann-Clausen, p. 164, 166-168, fig. 6, nos 1-6.

Age. LO: Selandian.

Remarks. Senegalinium iterlaaense differs from Isabelidinium viborgense in having a striate periphragm.

Genus Senoniasphaera Clarke \& Verdier 1967

Type. Clarke \& Verdier 1967, plate 14, fig. 8, as Senoniasphaera protrusa.

1967 Senoniasphaera Clarke \& Verdier, p. 61. 
Remarks. The cavate cysts included in Senoniasphaera have the typical offset sulcal notch of areoligeraceans. The operculum of the apical archaeopyle is always free.

\section{Senoniasphaera inornata (Drugg 1970) Stover \& Evitt 1978}

(Plate 13, fig. 5)

1970 Chiropteridium inornatum Drugg, p. 811, 812, fig. 3C-F.

1978 Senoniasphaera inornata (Drugg) - Stover \& Evitt, p. 80.

Age. LO: Danian.

Remarks. Brinkhuis \& Schiøler (1996) recorded Senoniasphaera inornata from the early Danian of the Geulhemmerberg Cretaceous-Palaeogene boundary section in Limburg, south-eastern Netherlands. This observation accords with the age of this species in sections at Stevns Klint (Denmark) and Alabama as recorded by Hansen et al. (1986) and Habib (1994) respectively. Senoniasphaera inornata therefore appears to be a good Danian index species. Williams et al. (2004) placed the LO of the species close to the top of the Danian.

\section{Senoniasphaera microreticulata Brideaux \& McIntyre 1975}

(Plate 13, fig. 6)

1975 Senoniasphaera microreticulata Brideaux \& McIntyre, p. 35, plate 11, figs 7-12; plate 12, figs 1-8.

1981 Canningia microreticulata (Brideaux \& McIntyre) - Below, p. 31.

Age. LO: Cenomanian.

Remarks. Lentin \& Williams (1981, p. 33) retained this species in Senoniasphaera.

\section{Senoniasphaera rotundata Clarke \& Verdier 1967} (Plate 13, fig. 7)

1967 Senoniasphaera rotundata Clarke \& Verdier, p. 62,63 , plate 14 , figs $1-3$; text-fig. 25 .

Age. LO: latest Campanian.

Remarks. In Senoniasphaera rotundata, the endocyst does not protrude into the antapical horns.

\section{Genus Simplicidinium gen. nov.}

Type. Eaton 1976, plate 21, fig. 5, as Impletosphaeridium insolitum.

Etymology. The name derives from the Latin simplicis, meaning simplicity, in reference to the relatively simple morphology of the cyst, comprising a spiny ball with an apical archaeopyle.

Diagnosis. Proximochorate to chorate dinoflagellate cysts with a more or less symmetrical spheroidal to ovoidal central body. Spines or processes numerous, isolated and non-tabulate, distally closed, with symmetrical distal terminations. Archaeopyle apical, type $4 \mathrm{~A}_{1^{\prime}-4^{\prime}}$, operculum attached or detached.

Remarks. There seems to be considerable confusion currently surrounding the generic assignment of chorate species with non-tabulate spines/processes and a cryptic, or not clearly discernible or consistent archaeopyle. Forms with a consistent apical archaeopyle and at least some asymmetrical processes are assignable to Cleistosphaeridium (Eaton et al. 2001). Islam (1993) proposed Downiesphaeridium, purportedly for forms with an apical archaeopyle and simple non-tabulate processes. The processes of the type of Downiesphaeridium are typical of Lingulodinium, and the archaeopyle in the type of Downiesphaeridium looks precingular; it is thus suggested here that Downiesphaeridium may be a taxonomic junior synonym of Lingulodinium, but at least should not be used beyond the type. Many authors have assigned species that they consider to be chorate dinoflagellates but show no evidence of an archaeopyle to Impletosphaeridium, the type of that genus being suitably cryptic in its archaeopyle type. Similar species deemed not to be dinoflagellates are assignable to the acritarch genus Baltisphaeridium.

Simplicidinium insolitum (Eaton 1976) comb. nov. (Plate 13, figs 9, 10)

1976 Impletosphaeridium insolitum Eaton, p. 308, plate 21, figs 5, 8; text-fig. 25B.

1978 Cleistosphaeridium? insolitum (Eaton) - Stover \& Evitt, p. 31.

Age. Local peak: earliest Bartonian.

Remarks. Eaton (1976, p. 308) commented on the presence of a polygonal opening in some of the specimens of Simplicidinium (as Impletosphaeridium) insolitum; such 
openings are readily apparent in his accompanying illustrations (Eaton 1976, plate 21, figs 5, 8). We thus assign this species, as type, to Simplicidinium on the basis of the morphology of the holotype and because several of the specimens in this study also have an apical archaeopyle.

\section{Genus Sophismatia Williams et al. 2015}

Type. Williams \& Downie 1966a, plate 20, figs 2, 4, text-fig. 49, as Wetzeliella tenuivirgula.

\section{Sophismatia Williams et al., p. 312, 313.}

Remarks. Williams et al. (2015) are followed here in restricting Sophismatia to wetzelielloideans with an equiepeliform $2 \mathrm{a}$ archaeopyle and trabeculate processes.

\section{Sophismatia tenuivirgula (Williams \& Downie} 1966b) Williams et al. 2015

(Plate 13, fig. 8)

1966b Wetzeliella tenuivirgula Williams \& Downie, p. 188 , 189, plate 19 , figs $1,2,4,5,7$; textfigs 49, 50 .

1976 Kisselevia tenuivirgula (Williams \& Downie) Lentin \& Williams, p. 136.

1989 Charlesdowniea tenuivirgula (Williams \& Downie) - Lentin \& Vozzhennikova, p. 227.

2015 Sophismatia tenuivirgula (Williams \& Downie) - Williams et al., p. 313.

Age. LO: Lutetian.

Remarks. The holotype of Sophismatia tenuivirgula (Williams \& Downie 1966b, plate 19, figs 2-4; text-fig. 49) clearly shows an equiepeliform archaeopyle, with the endo- and periarchaeopyle being of almost identical size. The only difference is anteriorly, where the periarchaeopyle extends slightly beyond the endoarchaeopyle.

\section{Genus Spinidinium Cookson \& Eisenack 1962}

Type. Cookson \& Eisenack 1962, plate 1, figs 1, 2, as Spinidinium styloniferum.

1962 Spinidinium Cookson \& Eisenack, p. 489.

2003 Magallanesium Quattrocchio \& Sarjeant, p. 138, 140.

2003 Volkheimeridium Quattrocchio \& Sarjeant, p. $136,138$.

Remarks. In their extensive review of Spinidinium, Vozzhennikovia and related genera, Sluijs et al. (2009) emended the diagnosis of Spinidinium. They restricted the genus to peridiniacean taxa with proximosutural spines, a steno- to isodeltaform 2a plate and an $\mathrm{I}_{2 \mathrm{a}}$ archaeopyle, with the operculum typically attached posteriorly.

\section{Spinidinium echinoideum (Cookson \& Eisenack} 1960a) Lentin \& Williams 1976

(Plate 13, figs 11, 12)

1960a Deflandrea echinoidea Cookson \& Eisenack, p. 2, plate 1, figs 5, 6 .

1976 Spinidinium echinoideum (Cookson \& Eisenack) - Lentin \& Williams, p. 64.

1978 Vozzhennikovia echinoideum (Cookson \& Eisenack) - Stover \& Evitt, p. 130.

2003 Spinidinium? echinoideum (Cookson \& Eisenack) - Quattrocchio \& Sarjeant, p. 136.

Age. LO: Selandian.

Remarks. Sluijs et al. (2009, p. 47) noted: "Both the holotype (Cookson \& Eisenack 1960a, plate 1, Fig. 5) and specimens illustrated in Sverdlove \& Habib (1974, plate 1 , figs $3,5,6$; text-fig. 1 ) show the 2 a plate is isodeltaform to isothetaform. The $2 \mathrm{a}$ also remains attached to the $4^{\prime \prime}$ plate. Further the ornamentation is predominantly proximosutural. For the above reasons we include this species in Spinidinium without question."

\section{Genus Spiniferites Mantell 1850}

Type. Ehrenberg 1838, plate 1, fig. 5, as Xanthidium ramosum, designated by Davey \& Williams (1966b, p. 32), as lectotype of Hystrichosphaera ramosa.

1850 Spiniferites Mantell, p. 191.

1933b Hystrichosphaera Wetzel, p. 33; name not validly published.

1937 Hystrichosphaera Wetzel ex Deflandre, p. 61.

1953 Hystrichokibotium Klumpp, p. 387.

Remarks. Spiniferites is characterised by having its gonyaulacoidean tabulation expressed by sutural ridges or membranes as well as gonal and sometimes sutural processes. Distally, the gonal processes are always trifurcate, and the sutural processes are always bifurcate. The archaeopyle is precingular, with formula $\mathrm{P}_{3^{\prime \prime}}$, with a free operculum.

\section{Spiniferites ovatus Matsuoka 1983}

(Plate 13, fig. 13) 
1983

Spiniferites ovatus Matsuoka, p. 134, 135 , plate 3 , figs $1 \mathrm{a}-\mathrm{c}, 2,3 \mathrm{a}, \mathrm{b}, 4 \mathrm{a}, \mathrm{b}$; text-fig. 19A, B.

non 1984 Spiniferites ovatus Bujak, p. 192, plate 3, figs 15-18; illegitimate junior homonym.

Age. LO: Messinian.

Remarks. Spiniferites ovatus differs from Spiniferites pseudofurcatus in having much shorter processes with shorter terminations.

Spiniferites pseudofurcatus (Klumpp 1953) Sarjeant 1970

(Plate 13, fig. 14)

1953 Hystrichokibotium pseudofurcatum Klumpp, p. 388, plate 16, figs 12, 14 .

1960 Hystrichosphaera tertiaria Eisenack \& Gocht, p. 515; text-fig. 4.

1966b Hystrichosphaera buccina Davey \& Williams, p. 42, 43, plate 4, fig. 1; text-figs 10, 11 .

1969 Hystrichosphaera pseudofurcata (Klumpp) Gocht, p. 32.

1970 Spiniferites pseudofurcatus (Klumpp) Sarjeant, p. 76.

Age. LO in present study: late Serravalian. LO according to Piasecki (2003): Tortonian.

Remarks. Spiniferites pseudofurcatus differs from Achomosphaera alcicornu only in having the tabulation clearly expressed by ridges. Although so similar, the stratigraphic ranges of the two species differ considerably, with Spiniferites pseudofurcatus having a much younger LO.

\section{Spiniferites scabrosus (Clarke \& Verdier 1967) Lentin \& Williams 1975}

(Plate 13, fig. 15)

1967 Hystrichosphaera scabrosus Clarke \& Verdier, p. 49, 50, plate 9, figs 7-10; text-fig. 21.

1975 Spiniferites scabrosus (Clarke \& Verdier) Lentin \& Williams, p. 2155.

Age. LO: Maastrichtian.

Remarks. The central body of Spiniferites scabrosus has a distinctive scabrate to granulate wall and bears long, slender processes. In some specimens, the sutural ridges or membranes are not obvious, but such forms are retained here in Spiniferites scabrosus.

\section{Genus Spongodinium Deflandre 1936}

Type. Ehrenberg 1838, plate 1, figs 1, 6, as Peridinium delitiense.

\section{Spongodinium Deflandre, p. 169, 170.}

Synopsis. Gonyaulacacean (cribroperidinioid) cysts that are proximate, spheroidal to subpolyhedral, with a rounded antapex and usually an apical protrusion or horn. Acavate. The wall is complexly reticulate to vesiculate, and its total thickness is sometimes greater along the cingulum and at the poles. Wall atabulate or with structure/ornament arranged to reflect or suggest tabulation. Archaeopyle precingular, with formula $\mathrm{P}_{3^{\prime \prime}}$, operculum free.

Remarks. The synopsis is similar to that provided by Fensome et al. (2009, p. 60). An ectophragm is not developed but may be partially simulated on the cyst outline by the outer margins of membranes that constitute the wall. The genus Samlandia is very similar in appearance to Spongodinium, but the precise morphology of the type is not clear from available illustrations (Eisenack 1954, plate 11, figs 12-15). However, an SEM micrograph of a specimen identified as Samlandia chlamydophora by one of the authors shows that an occasionally perforate ectophragm connects processes in all but the sutural areas. Such a morphology supports our interpretation that Samlandia can thus be differentiated from Spongodinium.

\section{Spongodinium delitiense (Ehrenberg 1838) Deflandre 1936}

(Plate 13, figs 16, 20)

1838 Peridinium delitiense Ehrenberg, p. 110, plate 1, figs 1, 6 .

1936 Spongodinium delitiense (Ehrenberg) Deflandre, p. 170, 171.

Age. LO: early Danian.

Remarks. The Labrador Margin specimens of Spongodinium delitiense show considerable variation in size. The larger specimens have an LO in the Maastrichtian and the smaller ones range up into the Danian. 
Spongodinium grossum (Manum \& Cookson 1964) comb. nov.

(Plate 14, figs 1-4)

1964 Chlamydophorella grossa Manum \& Cookson, p. 17, 18, plate 5, figs 1, 2.

1986 Chlamydophorella? grossa Ioannides, p. 16.

Age. LO: Campanian.

Remarks. In a description of Spongodinium (as Chlamydophorella) grossum, Ioannides (1986, p. 16) stated: "Archaeopyle of dubious position, possibly precingular, type $\mathrm{P}$ (or $2 \mathrm{P}$ ). Paracingulum often indicated by aligned processes, which may be joined proximally...." It is confirmed here that the archaeopyle is precingular, resulting from the loss of the 3 " plate. The operculum is free. Chlamydophorella has an apical archaeopyle, so this species is transferred to Spongodinium.

M. Pearce (personal communication 2015) has drawn our attention to the similarity between Spongodinium grossum and Isabelidinium? extremum. The latter species has a precingular archaeopyle and an outer wall or periphragm that forms an apical horn and a discontinuous pericyst. Thus, this species should be retained as Spongodinium? extremum, a combination originally proposed by Lentin \& Williams (1976). Spongodinium grossum and Spongodinium? extremum may be synonymous; the only obvious difference seems to be in the nature of the pericyst, which is more continuous and less perforate in Spongodinium grossum.

\section{Spongodinium obscurum (Manum \& Cookson 1964) comb. nov.}

(Plate 13, fig. 19)

1964 Scriniodinium obscurum Manum \& Cookson, p. 21, 22, plate 4, figs 5, 6 .

1978 Scriniodinium? obscurum (Manum \& Cookson) - Stover \& Evitt, p. 188.

2003 Endoscrinium obscurum (Manum \& Cookson) - Riding \& Fensome, p. 23.

Age. LO: Santonian.

Remarks. As demonstrated by Ioannides (1986, plates 5-8), intergradation exists between Spongodinium (as Endoscrinium) obscurum, Spongodinium grossum (as Chlamydophorella grossa) and a taxon that he called Spongodinium sp. In their description of Endoscrinium obscurum, Manum \& Cookson (1964, p. 21) stated:
"There are no distinct connections running between the capsule and the theca, but fine, irregular lines, the true nature of which is obscured by the many folds, may possibly represent supporting fibrils. The wall of the capsule is up to $1 \mu \mathrm{m}$ thick and sometimes indistinctly dotted.” The comments of Manum \& Cookson (1964) and Ioannides (1986), together with observations in this study, indicate that the species should be assigned to Spongodinium, and that the wall is best considered a complex autophragm, rather than being holocavate.

\section{Genus Stichodinium Williams et al. 2015}

Type. He Chengquan \& Wang Kede 1990, plate 2, fig. 3 , as Wilsonidium subtile.

\section{Stichodinium Williams et al., p. 314.}

Remarks. Williams et al. (2015) erected the genus Stichodinium for wetzelielloidean cysts with a latiepeliform archaeopyle and sutural or penitabular ornamentation that may be features of low relief or processes that are distally free.

\section{Stichodinium lineidentatum (Deflandre \& Cookson 1955) Williams et al. 2015}

(Plate 13, figs 17, 18)

1955 Wetzeliella lineidentata Deflandre \& Cookson, p. 253, 254, plate 5, fig. 5; text-figs 17, 18.

1976 Wilsonidium lineidentatum (Deflandre \& Cookson) - Lentin \& Williams, p. 139.

2015 Stichodinium lineidentatum (Deflandre \& Cookson) - Williams et al., p. 314.

Age. LO: Lutetian.

Remarks. The holotype of Stichodinium lineidentatum (Deflandre \& Cookson 1955, plate 5, fig. 5) clearly shows a latiepeliform archaeopyle.

\section{Genus Subtilisphaera Jain \& Millepied 1973}

Type. Jain \& Millepied 1973, plate 3, fig. 31, as Subtilisphaera senegalensis.

\section{Subtilisphaera Jain \& Millepied, p. 26, 27.}

Remarks. Our concept of the genus Subtilisphaera adheres to the synopsis presented in Fensome et al. (2009), who acknowledged uncertainty in interpreting the archaeopyle. Lentin \& Williams (1976, p. 118) considered that, where 
observable, Subtilisphaera has a combination archaeopyle, with the formula $\operatorname{AIP}_{\left(3^{\prime}+1-3 a+3-5^{\prime \prime}\right)}$, the operculum remaining attached along the posterior margin. Stover \& Evitt (1978, p. 238) considered the archaeopyle of Subtilisphaera to be "presumably intercalary". Bujak \& Davies (1983, p. 62) observed specimens from the Early Cretaceous of offshore eastern Canada, which they attributed to Subtilisphaera, with complete or incomplete archaeopyle sutures between the following plates: $2^{\prime} / 1$ a, $3^{\prime} / 1$ a $, 3^{\prime} / 2 \mathrm{a}, 3^{\prime} / 3 \mathrm{a} .4^{\prime} / 3 \mathrm{a}$ and with complete or incomplete archaeopyle sutures between individual intercalary plates. These authors termed this a transverse archaeopyle.

\section{Subtilisphaera perlucida (Alberti 1959) Jain \& Millepied 1973}

(Plate 14, fig. 5)

1959 Deflandrea perlucida Alberti, p. 102, plate 9, figs 16, 17.

1959 Deflandrea pirnaensis Alberti, p. 100, plate 8, figs 1, 5 .

1960 Scriniodinium cooksoniae Anderson, p. 30, plate 9, figs 1-3.

1973 Subtilisphaera perlucida (Alberti) - Jain \& Millepied, p. 27.

1973 Subtilisphaera pirnaensis (Alberti) - Jain \& Millepied, p. 27.

1990 Subtilisphaera? pirnaensis (Alberti) - Harker \& Sarjeant in Harker et al., p. 133.

Age. LO: Albian.

Remarks. Fensome et al. (2009, p. 61, 62) considered Subtilisphaera pirnaensis to be a taxonomic junior synonym of Subtilisphaera perlucida.

\section{Genus Surculosphaeridium Davey et al. 1966 emend. nov.}

Type. Sarjeant 1960, plate 6, fig. 2, as Hystrichosphaeridium cribrotubiferum.

\section{Surculosphaeridium Davey et al., p. 160, 161.}

Emended diagnosis. Chorate gonyaulacacean cysts with spheroidal central bodies. Acavate. Processes are solid and branched and/or distally furcate. There may be one to four processes per plate, sometimes forming complexes in cases where there is more than one process per plate. Archaeopyle apical, with the formula $A_{\left(1-4^{\prime}\right)}$; operculum free.
Remarks. Surculosphaeridium is emended to allow inclusion of forms with more than one process per plate. However, there must be processes or process complexes on all the plates, including the precingulars.

\section{Surculosphaeridium convocatum sp. nov.}

(Plate 14, figs 6-8)

Holotype. Plate 14, fig. 7, from a cuttings sample at 3510-3520 m in South Labrador N-19, GSC type collection no. 138128, sample P39834, slide 01, coordinates $7.8 \times 99.1$, England Finder G29/3-H28/2. Central body length (without apical operculum) 30 $\mu \mathrm{m}$, central body width $38 \mu \mathrm{m}$, processes up to about $12 \mu \mathrm{m}$. The sample from which the holotype derives is dated as Barremian-Aptian, indicating that the specimen represents caving.

Etymology. The epithet is from the Latin convocatum, to call together or assemble, in reference to the grouping of several processes per plate common in this species.

Diagnosis. A species of Surculosphaeridium in which at least the larger plates have more than one and up to four processes per plate. Processes may branch along their length and are always furcate distally.

Size. Central body length (without apical operculum) 29-34 $\mu \mathrm{m}$, central body width $30-38 \mu \mathrm{m}$, processes up to about $15 \mu \mathrm{m}$; three specimens measured.

Age. LO: early Campanian. Not plotted.

Remarks. Some plates, especially smaller ones such as cingulars, sulcals and apicals, may have only one process per plate, but others have two to four. Processes are characteristically furcate distally. Surculosphaeridium longifurcatum has one process per plate.

\section{Genus Talladinium Williams, Damassa, Fensome \& Guerstein in Fensome et al. 2009}

Type. Mao Shaozi \& Norris 1988, plate 13, fig. 6, as Charlesdowniea wulagense.

2009 Talladinium Williams, Damassa, Fensome \& Guerstein in Fensome et al., p. 61, 62.

Remarks. Williams, Damassa, Fensome \& Guerstein in Fensome et al. (2009) erected the genus Talladinium for wetzelielloidean cysts with a soleiform archaeopyle 
and processes that are distally united by ectophragmal membranes that delineate the tabulation.

\section{Talladinium? clathratum (Eisenack 1938) Williams, Damassa, Fensome \& Guerstein in Fensome et al. 2009}

(Plate 14, figs 9, 10)

1938 Wetzeliella clathrata Eisenack, p. 187; text-fig. 5.

1976 Kisselevia? clathrata (Eisenack) - Lentin \& Williams, p. 136.

1989 Charlesdowniea clathrata (Eisenack) - Lentin \& Vozzhennikova, p. 227.

2009 Talladinium? clathratum (Eisenack) Williams, Damassa, Fensome \& Guerstein in Fensome et al., p. 62.

Age. LO: latest Bartonian. Not plotted.

Remarks. As noted in Fensome et al. (2009, p. 62), the nature of the peri- and endoarchaeopyles in Talladinium? clathratum can not be ascertained from the original description of Eisenack (1938) or the expanded description of Eisenack (1954). From the late Eocene to early Oligocene age of the type material, however, it seems reasonable to deduce that this species has a soleiform archaeopyle. This explains why the species is questionably included in Talladinium.

\section{Talladinium pellis sp. nov.}

(Plate 14, figs 11, 12, 16)

Holotype. Plate 14, figs 11, 12, from a cuttings sample at $1840 \mathrm{~m}$ in Gjoa O-37, GSC type collection no. 138082, sample YD16082, slide 03, coordinates $050 \times$ 0907, England Finder E20/3. Size: pericyst length 94 $\mu \mathrm{m}$, width $76 \mu \mathrm{m}$; endocyst length $61 \mu \mathrm{m}$, width 57 $\mu \mathrm{m}$. The age determined for the sample from which the holotype was recovered is late Ypresian.

Etymology. The epithet is from the Latin pellis, meaning skin, in reference to the ectophragm, which surrounds most of the pericyst. It is a noun in apposition.

Diagnosis. A species of Talladinium in which processes of individual plates are distally united by a membrane that mimics the outline of the underlying plate. The ectophragm may be irregularly or regularly perforate.
Size. Pericyst length $89-94 \mu \mathrm{m}$, width $76-81 \mu \mathrm{m}$; endocyst length $61 \mu \mathrm{m}$ (both specimens), width 57-64 $\mu \mathrm{m}$; two specimens measured.

Age. LO: Priabonian.

Remarks. The ectophragmal membranes in Talladinium pellis form linear complexes that mirror the outline of the reflected plates, rather than forming a shield-like covering as in Talladinium? clathratum. This difference is not always easy to determine. Charlesdowniea coleothrypta has identical ornamentation but differs in having an equiepeliform archaeopyle.

Genus Tanyosphaeridium Davey \& Williams 1966a Type. Davey \& Williams 1966a, plate 6, fig. 7, text-fig. 20 , as Tanyosphaeridium variecalamum.

1966a Tanyosphaeridium Davey \& Williams, p. 98.

Remarks. Tanyosphaeridium is characterised by an elongate ellipsoidal central body, slender open processes and an apical archaeopyle. The processes number about 30 or more and cannot be readily related to tabulation.

Tanyosphaeridium xanthiopyxides (Wetzel 1933a ex Deflandre 1937) Stover \& Evitt 1978

(Plate 15, fig. 7)

1933a Hystrichosphaera xanthiopyxides Wetzel, p. 44, 45, plate 4, fig. 25 (name not validly published).

1937 Hystrichosphaeridium xanthiopyxides Wetzel ex Deflandre, p. 77.

1965 Baltisphaeridium xanthiopyxides (Wetzel ex Deflandre) - Downie \& Sarjeant, p. 98.

1968 Hystrichosphaeridium? xanthiopyxides (Wetzel ex Deflandre) - Morgenroth, p. 556.

1969 Prolixosphaeridium? xanthiopyxides (Wetzel ex Deflandre) - Davey et al., p. 17.

1978 Tanyosphaeridium xanthiopyxides (Wetzel ex Deflandre) - Stover \& Evitt, p. 85.

Age. LO: Danian.

Remarks. Fensome et al. (2009, p. 62) is followed here in using the earliest proposed name, Tanyosphaeridium xanthiopyxides, for all the Late Cretaceous - Paleocene forms of Tanyosphaeridium. 
Genus Taurodinium gen. nov.

Type. Plate 14, fig. 13, as Taurodinium granulatum.

Etymology. The name derives from the Latin taurus, meaning bull, in reference to the two prominent apical horns.

Description. Dorso-ventrally compressed ceratiacean cysts with an autocyst having six horns: two apical, two lateral and two antapical, all with closed, acuminate to slightly rounded terminations. Autophragm smooth to finely granulate or perforate and very thin. Paratabulation not expressed. Cingulum may be indicated above the two lateral horns but there is no indication of a sulcus. Archaeopyle apical with a straight to weakly angular margin; operculum usually attached.

Remarks. Nyktericysta and Vesperopsis have the same thin and fragile appearance as Taurodinium, but have only a single apical horn. Satyrodinium Lentin \& Manum 1986, has two to three apical and one or more antapical horns, but is a peridiniacean cyst with an intercalary archaeopyle, lacks lateral horns, and is cavate. The acritarch genus Limbicysta Marshall 1989, from Upper Cretaceous nonmarine to nearshore environments, has an elongate split protrusion at one end that shows some resemblance to the apical horns of Taurodinium but Limbicysta lacks a regular opening and other protrusions.

\section{Taurodinium granulatum sp. nov.}

(Plate 14, figs 13-15, 17, 18)

1992 Gen. et sp. indet. Piasecki et al., fig. 6L, M.

1995 Nyktericysta sp. Gregory \& Hart, plate 7, figs 6, 7.

2011 Gen. et sp. indet. Piasecki et al. 1992 - NøhrHansen et al., figs 3, 4.

2012 Gen. et sp. indet. Piasecki et al. 1992 - NøhrHansen, plate X, figs 12-19.

Holotype. Plate 14, fig. 13, from a cuttings sample at 2340 $\mathrm{m}$ in Ikermiut-1, offshore West Greenland, MGHU no. 31333, sample Ikermiut 2289, slide s-261-3, England Finder T19-1. Size: overall length $105 \mu \mathrm{m}$, length of body $54 \mu \mathrm{m}$, body width $35 \mu \mathrm{m}$, length of apical horns up to $30 \mu \mathrm{m}$, length of lateral horns $13 \mu \mathrm{m}$, length of antapical horns $22 \mu \mathrm{m}$, wall less than $1 \mu \mathrm{m}$ thick. The age determined for the sample from which the holotype was recovered is late Thanetian.

Etymology. The epithet is from the Greek granulatum meaning granulate, in reference to the surface ornamentation.
Description. A species of Taurodinium with two apical horns of approximately equal length, two short lateral horns and two antapical horns of unequal length with the left being the longer. The antapical horns narrow at about one-third along their length. Autophragm smooth to finely granulate, thin, hyaline and often wrinkled. The apical horns appear to be oriented in a plane perpendicular to that of the other horns, giving the cyst a twisted look.

Size. Overall length $75-105 \mu \mathrm{m}$, length of body $40-70$ $\mu \mathrm{m}$, body width $28-60 \mu \mathrm{m}$, length of apical horns $15-$ $25 \mu \mathrm{m}$, length of lateral horns 7-17 $\mu \mathrm{m}$, length of antapical horns $10-32 \mu \mathrm{m}$; seven specimens measured.

Age. LO: Bartonian; peak early Ypresian.

Remarks. Taurodinium granulatum was originally recorded as 'Gen. et sp. indet.' by Piasecki et al. (1992) from a miospore-dominated palynological assemblage devoid of other dinocysts. The assemblage was from a silty shale clast in subaqueous volcanic breccias from the lower Rinks Dal Member, Maligât Formation, West Greenland; the basalts were radiometrically dated as $61.2 \pm 0.4$ $\mathrm{Ma}$, and thus of Selandian age (Larsen et al. 2015). Gregory \& Hart (1995) recorded a specimen of $N y k$ tericysta sp. that may be assignable to Taurodinium granulatum from sediments dated as Thanetian. NøhrHansen et al. (2011) recorded Gen. et sp. indet. of Piasecki et al. (1992) from Thanetian - lower? Ypresian non-marine or marginal marine deposits of north-eastern Greenland. Recently, this species has been found to be common in the Thanetian-Ypresian non-marine or marginal marine Kulhøje Member in the Kangerlussuaq Basin, south-eastern Greenland (Nøhr-Hansen 2012). In the present study, Taurodinium granulatum was encountered in wells on the West Greenland continental margin in samples together with the Late Paleocene marker Axiodinium augustum, as well as in samples of Ypresian age from the Saglek Basin. However, the species has been mostly recorded from spore-dominated or marginal marine, algae-dominated assemblages. We thus follow Nøhr-Hansen (2012) in regarding it as a freshwater to brackish-water indicator.

\section{Genus Tenua Eisenack 1958}

Type. Eisenack 1958, plate 23, fig. 1, as Tenua hystrix.

1958 Tenua Eisenack, p. 410.

1981 Cerbia Below, p. 8. 
Remarks. The genus is distinguished from Cyclonephelium (incorporating Circulodinium) by having some processes showing alignment in penitabular rows. Aptea differs in having three horns - an apical, an antapical, and a third, probably postcingular - of variable development; the probable postcingular horn is always reduced. Cerbia is considered here to be a taxonomic junior synonym of Tenua.

\section{Tenua hystrix Eisenack 1958}

(Plate 14, figs 19, 20)

1958 Tenua hystrix Eisenack, p. 410, plate 23, figs 1-4; text-fig. 10.

1972 Tenua hystricella Eisenack \& Kjellström, p. 1039.

1978 Cyclonephelium hystrix (Eisenack) - Davey, p. 894.

Age. LO: late Aptian.

Remarks. Sarjeant (1985b, p. 94, 95) retained this species in Tenua. The distribution of processes in this species is variable. The material in this study includes forms in which processes are largely absent on midventral and mid-dorsal surfaces (for example that shown in Plate 14, fig. 19).

\section{Genus Thalassiphora Eisenack \& Gocht 1960}

Type. Eisenack 1954, plate 12, fig. 17, as Pterospermopsis pelagica.

1960 Thalassiphora Eisenack \& Gocht, p. 513.

1966a Erikania Morgenroth, p. 27.

1980 Subathua Khanna \& Singh, p. 307, 308.

Remarks. Fensome et al. (2009, p. 62) provided a comprehensive synopsis for Thalassiphora based on the emendations of the genus by Williams \& Downie (1966a, p. 234), Gocht (1968, p. 153) and Benedek \& Gocht (1981, p. 59).

\section{Thalassiphora delicata Williams \& Downie 1966a}

(Plate 15, fig. 1)

1966a Thalassiphora delicata Williams \& Downie, p. 235, plate 26, fig. 8 .

1973 Disphaeria delicata Norvick, p. 43.

Age. LO: middle Bartonian. Not plotted.
Remarks. Lentin \& Williams (1977a, p. 54) retained this species in Thalassiphora.

\section{Thalassiphora fenestrata Liengjarern et al. 1980}

(Plate 15, figs 2-4)

1980 Thalassiphora fenestrata Liengjarern et al., p. 489 , plate 54 , fig. 1 .

Age. LO: earliest Rupelian.

Remarks. Thalassiphora fenestrata has large fenestrations, which are restricted to lateral and ventral areas of the pericyst. Liengjarern et al. (1980, p. 489) considered its stratigraphic range to be late Eocene to early? Oligocene.

\section{Thalassiphora pelagica (Eisenack 1954) Eisenack \& Gocht 1960}

(Plate 15, figs 5, 6)

1954 Pterospermopsis pelagica Eisenack, p. 71, plate 12, figs 17, 18.

1960 Thalassiphora pelagica (Eisenack) - Eisenack \& Gocht, p. 513, 514.

1966 Thalassiphora sueroi Pöthe de Baldis, p. 224, 225, plate 2, fig. d.

1973 Disphaeria pelagica (Eisenack) - Norvick, p. 46.

1981 Disphaeria sueroi (Pöthe de Baldis) - Yun Hyesu, p. 70.

Age. LO: Chattian.

Remarks. Lentin \& Williams (1977a, p. 54) retained this species in Thalassiphora.

\section{Genus Trichodinium Eisenack \& Cookson 1960}

Type. Eisenack \& Cookson 1960, plate 2, fig. 4, as Trichodinium pellitum.

1960 Trichodinium Eisenack \& Cookson, p. 5.

Remarks. Trichodinium is a spheroidal to ovoidal proximate gonyaulacacean cyst that apically can have a horn or several spines. The autophragm may be tabulate, as determined from the alignment of some of the numerous short spines or bifid processes. Its surface has been described as fibro-pitted (see Fensome et al. 2009, p. 64). The archaeopyle is precingular, with the formula $\mathrm{P}_{3^{\prime}}$; the operculum is free. Fensome et al. (2009, p. 64) 
discussed the morphological similarity between Trichodinium and Xenicodinium Klement 1960. They recommended that Xenicodinium should be restricted to its type material and all forms with the appropriate morphology should be included in Trichodinium.

\section{Trichodinium castanea Deflandre 1935 ex Clarke \& Verdier 1967}

(Plate 15, fig. 8)

1935 Palaeoperidinium castanea Deflandre, p. 229, plate 6, fig. 8; name not validly published.

1967 Trichodinium castanea (Deflandre) - Clarke \& Verdier, p. 19, 20.

Age. LO: Campanian.

Remarks. Some tabulation can usually be discerned on Trichodinium castanea, which is also distinguished by its dense covering of short, acuminate to bifid spines.

\section{Genus Trithyrodinium Drugg 1967}

Type. Drugg 1967, plate 3, fig. 2, as Trithyrodinium evittii.

\section{Trithyrodinium Drugg, p. 20.}

Synopsis. Peridiniacean (deflandreoid) cysts that are proximate and rounded to peridinioid in shape, with an antapex that is rounded, symmetrical or, more usually weakly to strongly asymmetrical, the left side being larger; endophragm rounded pentagonal to subcircular in dorso-ventral outline. Cavate; endocyst sometimes strongly developed with a fragile or thin-walled periphragm that is easily lost. Archaeopyle intercalary, with formula $\mathrm{I}_{(1-3 \mathrm{a})}$; operculum free, compound. Plate $2 \mathrm{a}$ is always iso- to stenodeltaform.

Remarks. The synopsis is largely a repeat of that provided by Fensome et al. (2009, p. 64), though with the concept broadened to include rounded forms and to recognise that the pericyst may be durable. The $2 \mathrm{a}$ plate, which is revealed through archaeopyle development, can show some variation in width but is always deltaform. The genus Pierceites also has a 3I archaeopyle but the endocyst is absent or weakly developed.

Trithyrodinium? conservatum sp. nov.

(Plate 15, figs 9-14)

2003 Deflandrea sp.1 Nøhr-Hansen, plate 3, figs 4-6.
Holotype. Plate 15, fig. 12 and Nøhr-Hansen (2003, plate 3, fig. 6), from a sidewall-core sample at $1155 \mathrm{~m}$ in Ikermiut 1, MGHU no. 26502, sample 04E006504, slide 2, co-ordinates $36.0 \times 97.1$, England Finder U36/1. Pericyst length $60 \mu \mathrm{m}$, width $63 \mu \mathrm{m}$, endocyst length 44 $\mu \mathrm{m}$, width $52 \mu \mathrm{m}$. The age determined for the sample from which the holotype was recovered is Lutetian.

Etymology. The epithet is from the Latin conservatus, meaning retain or conserve, in reference to the constant presence of the pericyst.

Description. A species of Trithyrodinium with a commonly rounded but sometimes ovoidal pericyst that is always present. The endocyst generally mimics the shape of the pericyst. As a rule the cyst is circumcavate, but the endocyst may occasionally be in partial contact with the pericyst. The periphragm and endophragm are both thin, at the most slightly over $1 \mu \mathrm{m}$ thick. The periphragm varies from laevigate (the usual condition), to faintly granulate or verrucate. The I to $3 \mathrm{I}$ archaeopyle is formed from the loss of one to three intercalary plates individually, any of which can remain attached posteriorly.

Size. Pericyst length 48-60 $\mu \mathrm{m}$, width 49-65 $\mu \mathrm{m}$, endocyst length 44-51 $\mu \mathrm{m}$, width 43-56 $\mu \mathrm{m}$; seven specimens measured.

Age. LO: Lutetian. Not plotted.

Remarks. Trithyrodinium? conservatum is unusual in that the pericyst is always preserved. When the pericyst has a subdued granulate or verrucate ornamentation, this tends to be restricted to the mid-dorsal and mid-ventral regions. Folds are consistently present on the pericyst but appear to be random. The exact nature of the archaeopyle is unclear. In some specimens its polygonal shape appears to indicate that multiple plates are missing, but in others it appears to reflect loss of a single intercalary plate. Because of the uncertainty regarding the archaeopyle, the species is only assigned questionably to Trithyrodinium.

\section{Trithyrodinium evittii Drugg 1967}

(Plate 15, figs 17-19)

1967 Trithyrodinium evittii Drugg, p. 20, plate 3, figs 2, 3; plate 9, fig. 2 .

1969b Trithyrodinium fragile Davey, p. 11, plate 3, figs 6,9 .

Age. LO: Danian. 


\section{Trithyrodinium quinqueangulare Marheinecke 1992}

(Plate 15, fig. 16)

1992 Trithyrodinium quinqueangulare Marheinecke, p. 95, plate 19, figs 9-11.

Age. LO: Maastrichtian.

Remarks. Trithyrodinium quinqueangulare has a pericyst and endocyst, which are sometimes closely appressed. Both pericyst and endocyst are pentagonal and have two more or less equal antapical protuberances. The cingulum is clearly delineated. Plate $4^{\prime \prime}$ is reduced in an anterior-posterior direction. Some of the Labrador Margin specimens have a verrucate endophragm.

\section{Trithyrodinium suspectum (Manum \& Cookson 1964) Davey 1969b}

(Plate 15, fig. 15)

1964 Hexagonifera suspectum Manum \& Cookson, p. 9, 10, plate 1, figs 9-13.

1969b Trithyrodinium suspectum (Manum \& Cookson) - Davey, p. 12.

Age. LO: Campanian.

Remarks. Trithyrodinium suspectum has a thick granular endophragm, which appears to be tectate. The archaeopyle may form from the detachment of the $1 \mathrm{a}$ and $3 \mathrm{a}$ plates, whereas the $2 \mathrm{a}$ plate can remain attached posteriorly, along its boundary with the 4 " plate. One specimen of Trithyrodinium suspectum illustrated in Manum \& Cookson (1964, plate 1, fig. 11) has a stenodeltaform $2 \mathrm{a}$ plate rather than the more commonly observed isodeltaform $2 \mathrm{a}$.

\section{Genus Tuberculodinium Wall 1967}

Type. Rossignol 1962, plate 2, fig. 1, as Pterospermopsis? vancampoae.

\section{Tuberculodinium Wall, p. 114.}

Synopsis. Goniodomacean (gambierdiscoid) cysts proximate, preicyst and endocyst both discoidal to subspheroidal. Holocavate. Numerous intratabular pillar- to barrel-shaped processes support an ectophragm. Archaeopyle antapical, involving usually 2-3 paraplates, operculum free, compound.
Remarks. Tuberculodinium represents the cysts of Pyrophacus, with its multiplate tabulation; the ectophragmal supports (processes), although numerous, can be readily interpreted as intratabulate.

\section{Tuberculodinium vancampoae (Rossignol 1962)} Wall 1967

(Plate 15, fig. 20)

1962 Pterospermopsis? vancampoae Rossignol, p. 134, plate 2, fig. 1 .

1967 Tuberculodinium vancampoae (Rossignol) Wall, p. 114, 115.

1971 Pyrophacus vancampoae (Rossignol) - Wall \& Dale, p. 234.

Age. LO: Tortonian?

Remarks. Head (1996, p. 1232) retained this species in Tuberculodinium.

\section{Genus Vesperopsis Bint 1986}

Type. Bint 1986, plate 5, figs 9, 12-13; text-fig. 5, as Vesperopsis mayii.

\section{Vesperopsis Bint, p. 156.}

Remarks. Vesperopsis is a proximate ceratiacean cyst with an autophragm that has at least three horns - one apical and two antapical. Commonly, it may also have equatorial horns with or without pre- and postcingular branches. The archaeopyle is apical, with the formula $\mathrm{A}_{\left(1-4^{\prime}\right)}$; the operculum is usually attached. Vesperopsis was emended by Qiao Xiuyun et al. (1992, p. 32, 33, 36, 37), Wan Chuanbiao \& Qiao Xiuyun (1994, p. 503) and Mao Shaozhi et al. (1999, p. 149, 150). However, we adhere to the synopsis of Fensome et al. (2009, p. 65).

\section{Vesperopsis longicornis (Batten \& Lister 1988) Harding 1990}

(Plate 16, figs 1, 2)

1988 Australisphaera longicornis Batten \& Lister, p. 340, 341, fig. 1b-e, g.

1990 Vesperopsis longicornis (Batten \& Lister) Harding, p. 21.

Age. LO: Albian. 
Remarks. Harding (1990, p. 21) emended the diagnosis of Vesperopsis longicornis, based on it having an autophragm and an attached operculum. According to Harding, an unusual aspect of Vesperopsis longicornis is that the operculum appears to be attached dorsally; operculum attachment in ceratiacian cysts, where present, is almost always ventral.

\section{Genus Wallodinium Loeblich Jr. \& Loeblich III 1968}

Type. Cookson \& Eisenack 1960b, plate 39, fig. 4, as Diplotesta glaessneri.

1960b Diplotesta Cookson \& Eisenack, p. 256; name illegitimate.

1968 Wallodinium Loeblich Jr. \& Loeblich III, p. 212.

Synopsis. Proximate gonyaulacalean cyst, elongate crescent-shaped to subcylindrical. Bicavate, circumcavate or epicavate. Pericyst much longer than endocyst; both bodies generally rounded apically and antapically, although the endocyst may have short horns. Tabulation indicated by apical archaeopyle, with inferred formula of $A_{\left(1-4^{\prime}\right)}$; peri- and endoarchaeopyle free or attached. Sometimes an equatorial constriction or ornamentation alignment marks a cingulum. Wall smooth or with ornamentation of low relief.

Remarks. Wallodinium was considered to be an acritarch by Duxbury (1983, p. 68) and Fensome et al. (1990, p. 535). However, Riding (1994, p. 17, 18) emended the diagnosis to include reference to the indications of gonyaulacalean tabulation and the presence of an apical archaeopyle; the above synopsis is based on Riding's emendation.

\section{Wallodinium luna (Cookson \& Eisenack 1960a) Lentin \& Williams 1973}

(Plate 16, fig. 5)

1960a Diplotesta luna Cookson \& Eisenack, p. 10, 11, plate 3, fig. 21.

1973 Wallodinium luna (Cookson \& Eisenack) Lentin \& Williams, p. 140.

Age. LO: Campanian.

Genus Wetzeliella Eisenack 1938 emend. Williams, Damassa, Fensome \& Guerstein in Fensome et al. 2009

Type. Eisenack 1938, fig. 4, as Wetzeliella articulata.
1979 Gochtodinium Bujak, p. 310-312.

2009 Wetzeliella Eisenack - emend. Williams, Damassa, Fensome \& Guerstein in Fensome et al., p. 65.

Synopsis. Wetzelielloidean cysts with a soleiform archaeopyle and processes that are predominantly nontabular, although they can show some alignment, and are distally free.

\section{Wetzeliella articulata Wetzel in Eisenack 1938} emend. Williams, Damassa, Fensome \& Guerstein in Fensome et al. 2009

(Plate 16, figs 3, 4)

1938 Wetzeliella articulata Wetzel in Eisenack, p. 187 , text fig. 4 .

1938 Palaeoperidinium articulatum Wetzel in Eisenack, p. 187 (name not validly published).

1948 Hystrichosphaeridium articulatum (Wetzel in Eisenack) - Pastiels, p. 42.

1960 Wetzeliella echinulata Vozzhennikova, plate 3, fig. 3 (name not validly published).

1967 Rhombodinium coronatum Vozzhennikova, p. 170,171 , plate 89 , figs $1-3$, 5 ; plate 90 , figs $1-5$.

1967 Wetzeliella echinulata Vozzhennikova, p. 164, 165.

1975 Wetzeliella horrida Jan du Chêne \& Châteauneuf, p. 28, 30, plate 1, figs 1-7; plate 3, figs 1-6.

1976 Wetzeliella coronata (Vozzhennikova) - Lentin \& Williams, p. 131.

Age. LO: Rupelian. Not plotted.

Remarks. According to the literature, Wetzeliella articulata has a stratigraphic range of Eocene-Oligocene. But when the species is restricted to wetzeleilloideans with a soleiform archaeopyle, intratabular processes and five horns, its stratigraphic range is more restricted, being Bartonian to Rupelian.

\section{Genus Xenascus Cookson \& Eisenack 1969}

Type. Cookson \& Eisenack 1969, fig. 1I, J, as Xenascus australensis.

1969 Xenascus Cookson \& Eisenack, p. 7.

1938 Wetzeliella Eisenack, p. 187. 
Remarks. Fensome et al. (2009, p. 67) provided a comprehensive synopsis of Xenascus in which they referred to lateral rather than postcingular, horn(s) because they seem to emanate from the cingulum as well as postcingular areas. Fensome et al. (2009) also discussed the emendations of Yun Hyesu (1981, p. 60) and Stover \& Helby (1987, p. 128).

Xenascus ceratioides (Deflandre 1937) Lentin \&Williams 1973

(Plate 16, figs 9, 10)

1937 Hystrichosphaera ceratioides Deflandre, p. 66, 67, plate 12 (also labelled as plate 9), figs 7, 8 .

1967 Pseudoceratium ceratioides (Deflandre) Clarke \& Verdier, p. 60.

1970 Spiniferites ceratioides (Deflandre) - Sarjeant, p. 76.

1971 Phoberocysta ceratioides (Deflandre) - Davey \& Verdier, p. 26.

Age. LO: Campanian.

Remarks. Xenascus ceratioides has three horns: one api$\mathrm{cal}$, one lateral and one antapical. The horns are not perforated.
Xenascus wetzelii Slimani 1996 ex Slimani 2001a

(Plate 16, figs 6-8)

1985 Odontochitina wetzelii Wilson in Foucher in Robaszynski et al., p. 33, plate 10, figs 9-12; name not validly published.

1996 Xenascus wetzelii Slimani, p. 380, 381, plate 3, figs F, G; plate 4, figs A, B; text-fig. 7A, B; name not validly published.

2001a Xenascus wetzelii Slimani 1996 ex Slimani, p. 9, plate 2, figs 3,4 .

Age. LO: Campanian.

Remarks. Xenascus wetzelii is cornucavate to circumcavate. It has a long postcingular horn and a long antapical horn, both of which are perforate distally and can be acuminate or bifurcate at their extremities. Tabulation is clearly shown by parasutural crests and gonal processes, the latter being acuminate, bifurcate or trifurcate. Slimani (2001a, p. 9; 2001b, p. 194) considered Odontochitina wetzelii to be a taxonomic junior synonym of Xenascus wetzelii.

\section{Systematics - acritarchs and other algae}

\section{Genus Fromea (Cookson \& Eisenack 1958) Yun Hyesu 1981}

Type. Cookson \& Eisenack 1958, plate 5, fig. 10, as Fromea amphora.

1958 Fromea Cookson \& Eisenack, p. 55.

1973 Xenascus ceratioides (Deflandre) - Lentin \& Williams, p. 144.

Remarks. Although many workers assign Fromea to the dinoflagellates, some (e.g. Duxbury 1980, p. 134; Fensome et al. 1990, p. 227; Fensome \& Williams 2004, p. 742 ) consider it to lack unequivocal morphological indications of dinoflagellate affinity and thus prefer to consider it an acritarch.

\section{Fromea nicosia Jansonius 1989}

(Plate 16, fig. 19)

1989 Fromea nicosia Jansonius, p. 67, plate 1, figs 2-7; text-fig. 1 .

Age. LO: early Campanian.

Fromea quadrangularis sp. nov.

(Plate 16, figs 11, 12, 15, 16)

Holotype. Plate 16, fig. 16, from a cuttings sample at $2375 \mathrm{~m}$ in Skolp E-07, MGUH no. 31352, sample YD15665, slide 04, co-ordinates $30.9 \times 111.9$, England Finder D31-1. Overall length $88 \mu \mathrm{m}$; maximum width $35 \mu \mathrm{m}$; minimum width $27 \mu \mathrm{m}$; wall thickness $1 \mu \mathrm{m}$. 
The age determined for the sample from which the holotype was recovered is early Campanian, Late Cretaceous.

Etymology. The epithet is from the Latin words quadra, meaning four and angularis, having angles, in reference to the quadrangular shape of specimens of this species.

Diagnosis. A slender elongate rectangular species of Fromea with a thin smooth wall and generally two longitudinal folds. Where present, the folds start at the antapex and continue along the body to the circular 'apical' opening. No accessory opening sutures or equatorial 'girdle' have been observed.

Size. Overall length $77-101 \mu \mathrm{m}$; maximum width 30 $45 \mu \mathrm{m}$; minimum width $27-37 \mu \mathrm{m}$; seven specimens measured.

Age. LO: early Campanian.

Remarks. Some specimens of Fromea quadrangularis are twisted, resulting in an elongate jar-like shape with longitudinal folds; other specimens have been slightly compressed, resulting in a weak equatorial extension and a splitting of the elongate folds.

\section{Genus Microsphaeridium Benedek 1972}

Type. Benedek 1972, plate 12, fig. 3a, b, as Microsphaeridium ancistroides.

\section{Microsphaeridium Benedek, p. 46, 47.}

Remarks. Benedek \& Sarjeant (1981, p. 346, 347) interpreted Microsphaeridium ancistroides as "the detached opercula of skolochorate dinoflagellate cysts." Pending further investigation, we prefer to consider Microsphaeridium to be an acritarch.

\section{Microsphaeridium ancistroides Benedek 1972}

(Plate 16, figs 13, 14, 17, 18)

1972 Microsphaeridium ancistroides Benedek, p. 47, plate 12, fig. 3a, b; text-fig. 21.

Age. LO: middle Miocene or younger; not well constrained. Not plotted.

\section{Genus Palambages Wetzel 1961}

Type. Wetzel 1961, plate 1, fig. 11, as Palambages morulosa.

1961 Palambages Wetzel, p. 338.
Remarks. Wetzel (1961) noted that the microfossils assigned to Palambages are identical to forms recorded as "Morulosae" in Wetzel (1933a, p. 23, 24, plate 4, figs 1-5). Wetzel (1933a) had compared these fossils with certain colonial algae, but noted their likeness to the egg-balls of planktonic crustaceans. Manum \& Cookson $(1964$, p. 23) considered them to represent colonies of green algae.

\section{Palambages spp.}

(Plate 16, fig. 20)

Age. Range not determined. Not plotted.

Genus Paralecaniella Cookson \& Eisenack 1970a

Type. Deflandre \& Cookson 1955, plate 9, fig. 6, as Epicephalopyxis indentata.

1970a Paralecaniella Cookson \& Eisenack, p. 323.

Remarks. Understanding of this genus, which is abundant in what seem to be shallow-water environments, is tenuous. Elsik (1977, p. 96), who emended the diagnosis of the genus and the type, considered Paralecaniella to be a dinocyst. We agree with Fensome et al. (2009, p. 67) that it is probably an algal cyst of non-dinoflagellate affinity.

\section{Paralecaniella indentata (Deflandre \& Cookson 1955) Cookson \& Eisenack 1970a}

(Plate 17, figs 1, 2)

1955 Epicepholopyxis indentata Deflandre \& Cookson, p. 292, plate 9, figs 5-7; text-fig. 56.

1970a Paralecaniella indentata (Deflandre \& Cookson) - Cookson \& Eisenack, p. 323.

1973 Scriniodinium? nilsii Kjellström, p. 42, fig. 35.

Age. Peak occurrence within the earliest Ypresian.

Remarks. The peak occurrence of Paralecaniella indentata is close to the Paleocene-Eocene boundary.

\section{Genus Pediastrum Meyen 1829}

Type. Meyen 1829, plate 43, figs 6-20, as Pediastrum duplex.

\section{Pediastrum Meyen, p. 772.}

Remarks. Pediastrum is a nonmotile coenobial green alga that is found in freshwater environments. 


\section{Pediastrum spp.}

(Plate 17, figs 3, 4)

Age. Range not determined. Not plotted. The range of the genus extends from Early Cretaceous to Recent (Batten 1996).

Remarks. The presence of Pediastrum spp. in some of the samples from marine deposits in the offshore wells is indicative of offshore transport of freshwater elements.

\section{Genus Tetraporina Naumova 1939}

Type. Tetraporina antiqua Naumova 1950, designated by Potonié (1960, p. 130).

1939 Tetraporina Naumova, p. 357.

1956 Tetrapidites Klaus in Meyer, p. 107.

1960 Tetraporopollenites Frantz, p. 559.

1963 Balmeella Pant \& Mehra, p. 116.

1980 Tetraporina Naumova - emend. Lindgren, p. 346.

Synopsis. Acid resistant, unicellular, tetrahedral or parallelepipedal microfossils with or without obvious pore or other dehiscence mechanism. Wall single or double layered.

Remarks. Described originally as representing pollen, Hemer \& Nygreen (1967) considered Tetraporina to be an algal genus, and it has been considered generally to represent the acritarchs or algae since then. The above synopsis largely follows the emended diagnosis of Lindgren (1980). Recognition of Tetaporina is based mainly on its distinctive tetrahedral or parallelepipedal shape (a parallelepiped is a geometric figure with six faces, all parallelograms and all opposite faces being similar and parallel). Although most commonly related to modern zygospores of the Zygnemataceae, Lindgren (1980) considered Teraporina to be polyphyletic and difficult to match with particular modern algae because of its simple shape, rigours of preservation and ontogenetic factors. Most algae to which Tetraporina can be related are freshwater. The stratigraphic range of the genus extends from Carboniferous to Quaternary.
There has been considerable debate about the nomenclatural status of Tetraporina. Jansonius \& Hills (1981, card 3917) considered that the name was not validly published in Naumova (1939) because it was proposed in anticipation of future acceptance of the name (see McNeill et al. 2012, Article 36.2). However, the case for this has not proved compelling for other authors (Lindgren 1980; Farr \& Zijlstra 1996). Although both sets of arguments have merit, for pragmatic reasons, here we accept Tetraporina as valid in Naumova (1939).

\section{Tetraporina sp. A}

(Plate 17, figs 5-7)

Description. A form of Tetraporina with a tetrahedral outline and indentations at the apices, although these are not clearly perforated by pores. The apices have no, or only short, extensions. The wall surface is smooth or has subdued ornament such as small verrucae. This form may correspond with one or more of the species described by Lindgren (1980), but morphological overlap, preservation and flexibility of the wall, and the quality of Lindgren's illustrations make comparison difficult.

Age. LO: earliest Rupelian.

\section{Tetraporina? sp. B}

(Plate 17, figs 8-12)

Description. A form with broad truncated extensions at each of the four apices. The extensions may be relatively short and converge on a central rhombic area, or they may just converge centrally without the development of a central rhombic area, in which case the entire specimen is essentially a cross-like structure. Tetraporina does not typically have extensions, so this form is only tentatively associated with that genus.

Age. Not plotted. 


\section{Systematics - miospores and fungal elements}

\section{Miospores}

\section{Genus Afropollis Doyle et al. 1982}

Type. Brenner 1968, plate 10, fig. 5, as Reticulatosporites jardinus.

1982 Afropollis Doyle et al., p. 44.

\section{Afropollis sp.}

(Plate 17, figs 18, 19)

Remarks. This form is assigned to Afropollis because of its possession of a network of reticulate to regulate muri separated from the nexine. The grains are apparently inaperturate. No ring furrow was discerned. The network of muri is considerably coarser than that exhibited by Afropollis jardinus, Afropollis operculatus and Afropollis zonatus.

Age. LO: Cenomanian.

Genus Appendicisporites Weyland \& Krieger 1953 Type. Weyland \& Krieger 1953, plate 11, fig. 54, as Appendicisporites tricuspidatus.

1953 Appendicisporites Weyland \& Krieger, p. 12.

\section{Appendicisporites potomacensis Brenner 1963}

(Plate 17, fig. 20)

1963 Appendicisporites potomacensis Brenner, p. 46, plate 6, figs 4, 5 .

1985 Plicatella potomacensis (Brenner) - Davies, p. A49.

Age. LO: mid-Cretaceous, but not well constrained. Not plotted.

Remarks. This species is retained in Appendicisporites, following Burden \& Hills (1989, p. 100) and Nichols \& Sweet (1993, p. 548).

Appendicisporites unicus (Markova in Ivanova \& Markova 1961) Singh 1964

(Plate 18, fig. 1)

1961 Anemia unica Markova in Ivanova \& Markova, p. 53, plate 20, fig. 3a, b.
1964 Appendicisporites unicus (Markova in Ivanova \& Markova) - Singh, p. 53.

1985 Plicatella unica (Markova in Ivanova \& Markova) - Davies, p. A 53.

Age. LO: mid-Cretaceous, but not well constrained. Not plotted.

Remarks. This species is retained in Appendicisporites, following Burden \& Hills (1989, p. 100).

\section{Genus Aquilapollenites Rouse 1957 emend. Braman 2013}

Type. Radforth \& Rouse 1954, plate 1, fig. 14, as " $\mathrm{N}_{2}$ ". Holotype lost; lectotype (possibly the holotype) selected from restored type slide by Tschudy \& Leopold (1971, plate 2, fig. 1); neotype designated by Srivastava \& Rouse (1970, plate 1, figs 4-7); all as Aquilapollenites quadrilobus.

1957 Aquilapollenites Rouse, p. 370.

1970 Hemicorpus Krutzsch, p. 107.

2013 Aquilapollenites Rouse - emend. Braman, p.14.

Remarks. Braman (2013) is followed here in considering Aquilapollenites to comprise triprojectate pollen that are heteropolar and have isolated sculptural elements. Other triprojectate pollen found in this study are assignable to Parviprojectus and Translucentipollis.

\section{Aquilapollenites quadrilobus Rouse 1957}

(Plate 17, figs 14, 15, 17)

1957 Aquilapollenites quadrilobus Rouse, p. 371, plate 2, figs 8, 9.

1961 Aquilapollenites polaris Funkhouser, p. 198, plate 1, figs 1, 2.

1961 Aquilapollenites pulcher Funkhouser, p. 198, plate 1, fig. 7a-c.

1970 Mancicorpus polaris (Funkhouser) - Stanley, p. 30 .

1970 Hemicorpus polaris (Funkhouser) - Krutzsch, p. 107.

1970 Hemicorpus pulcher (Funkhouser) - Krutzsch, p. 107.

1970 Mancicorpus pulcher (Funkhouser) Srivastava, p. 697. 
Aquilapollenites quadrilobus Rouse - emend. Srivastava \& Rouse, p. 1597.

Remarks. The synonymy above follows that in Braman (2013, p. 28). This widely recorded species is characterised by heteropolar grains with prominent spinate sculpture. According to Braman (2013) and A. Sweet (personal communication 2015), this species has a Late Cretaceous range, so the specimens recorded from the Labrador-Baffin Seaway are assumed to be reworked.

Age. LO: middle? Eocene (reworked?).

Genus Azolla Lamarck in Lamarck et al. 1783

Type. Azolla filiculoides Lamarck et al. 1783.

1783 Azolla Lamarck in Lamarck et al., p. 343.

\section{Azolla spp.}

(Plate 18, figs 2-4)

Age. LO: ?Bartonian. Frequent in late Ypresian.

Remarks. Azolla is a small moss-like, free-floating freshwater fern that occurs today in warm climates; it is famous for its nitrogen-fixing capability. Given the right combination of time and temperature, sediment rich in Azolla could represent major sources of oil. Azolla had coeval blooms in some Arctic and northern temperate areas during the Early to earliest Middle Eocene (e.g. Barke et al. 2011, 2012). Barke et al. (2012) concluded that the presence of the blooms accords with high-precipitation conditions modelled for the Early Eocene and implies the presence of extensive wetlands bordering the regional landmasses. They further suggested that Azolla blooms in the Arctic and Norwegian Sea basins may indicate widespread fresh ocean surface waters due to unprecedented discharge of water from the land and the semi-enclosed nature of those two basins. The occurrences of Azolla in Labrador Sea - Davis Strait wells are mostly restricted to a narrow time interval at the top of the Ypresian. Azolla has not been recorded in the offshore West Greenland wells. Evidence of extensive blooms of Azolla in the Labrador-Baffin Seaway was not encountered in this study, perhaps indicating that this marine basin was broadly open to the south and had limited or no connection to the Arctic basin (see Barke et al. 2012, fig. 4 and NøhrHansen et al. 2016).

The poor preservation and limited frequency of Azolla specimens in our study have precluded specific assigments, but several species are probably represented (see Barke et al. 2012). Previous studies suggest an LO of Azolla species in the earliest Lutetian.

\section{Genus Baculatisporites Pflug \& Thomson in Thomson \& Pflug 1953}

Type. Wolff 1934, plate 5, fig. 8, as Sporites priarius.

\section{Baculatisporites Pflug \& Thomson in} Thomson \& Pflug.

Synopsis. Trilete spores, with a subcircular ambitus; the laesurae are of variable length, sometimes reaching to the equator. The ornamentation of the exine is predominantly of bacula, although other types of element may be present. Distally, the bacula can be flat to multicrowned.

Remarks. In our synopsis for Baculatisporites, we allow for variation in both the width relative to the height of the baculae, so that the width may exceed the height, and in the nature of their distal terminations.

\section{Baculatisporites crenulatus sp. nov.}

(Plate 18, figs 6-8)

Holotype. Plate 18, fig. 8, from a cuttings sample at $1790-1800 \mathrm{~m}$ in Roberval K-92, GSC type collection no. 137889, sample P17684, slide 01 , co-ordinates 10.6 × 104.8, England Finder L34/2. Maximum overall diameter $65 \mu \mathrm{m}$. The age determined for the sample from which the holotype was recovered is Bartonian.

Etymology. The epithet is from the Latin crenulatus, meaning minutely crenulate, in reference to the toothed distal margin of the bacula.

Diagnosis. A species of Baculatisporites with sculptural elements that have variable distal terminations, ranging from blunt to rounded to crenulate. There is considerable variation in the nature of the distal terminations, and also in the length-to-width ratio of the elements: many are of greater length than width and hence true bacula, but others are of greater width than length.

Size. Diameter 52-65 $\mu \mathrm{m}$. Length of laesurae 15-18 $\mu \mathrm{m}$. Bacula height 3-12 $\mu \mathrm{m}$, width 3-7 $\mu \mathrm{m}$. Wall thickness $2-3 \mu \mathrm{m}$.

Age. LO: Bartonian. Not plotted. 
Remarks. The ratio of the width to height of the baculae and their distal variability from blunt to crenulated, distinguishes Baculatisporites crenulatus from other species of the genus.

\section{Genus Callialasporites Dev 1961}

Type. Balme 1957, plate 8, fig. 91, as Zonalapollenites trilobatus.

1961 Callialasporites Dev, p. 48.

1961 Applanopsis Döring, p. 112.

1961 Triangulopsis Döring, p. 113.

1962 Pflugipollenites Pocock, p. 72.

1964 Applanopsipollenites Levet-Carette, p. 107.

1970 Singhiapollis Kar \& Sah, p. 107.

Synopsis. Cavate, proximo-distally compressed miospores with a roughly circular to triangular or trilobate amb. The two wall layers are mostly appressed proximally and distally, but ambitally and sub-ambitally the wall layers are variously separated to produce a hollow zona that may be continuous or constricted to few (commonly three) to multiple vesicles and/or be radially plicated. The central body may be circular, triangular, or irregularly shaped. A proximal, non-functional triradiate mark may be present.

Remarks. The above description is condensed from a version provided by Fensome (1983), who gave an extensive review of this genus and its synonymy.

\section{Callialasporites dampieri (Balme 1957) Dev 1961}

(Plate 18, fig. 16)

1957 Zonalapollenites dampieri Balme, p. 32, plate 8, figs 88-90.

1961 Callialasporites dampieri (Balme) - Dev, p. 48.

1961 Applanopsis dampieri (Balme) - Döring, p. 113.

1962 Pflugipollenites dampieri (Balme) - Pocock, p. 72.

1963 Tsugaepollenites dampieri (Balme) Dettmann, p. 100.

Remarks. Singh (1971, p. 175) retained this species in Callialasporites.

Age. LO: Aptian.
Callialasporites obrutus Norris 1969

1969 Callialasporites obrutus Norris, p. 597, plate 110 , figs 6,7 .

Age. LO: Aptian.

Genus Caryapollenites Raatz 1938 ex Potonié 1960

Type. Potonié 1931, fig. 2, as Pollenites simplex.

1934 Caryae?-pollenites Potonié \& Venitz, p. 21; name not validly published.

1938 Caryapollenites Raatz, p. 19; name not validly published.

1960 Caryapollenites Potonié, p. 123.

Remarks. As Nichols \& Ott (1978) noted, the nomenclatural history of fossil pollen similar to the modern genus Carya is difficult to unravel. This is also true of species within Caryapollenites. Nichols \& Ott (1978) developed a biostratigraphic scheme for species of Caryapollenites and the closely related Momipites for Paleocene strata of the Wind River Basin of Wyoming. However, we have found species of these two genera widely distributed in Paleocene to Miocene sediments, and our observations do not conform to the tight Paleocene-restricted ranges proposed by Nichols \& Ott (1978). In our experience, firm ranges for individual species of these two genera have yet to be determined, though in the Labrador-Baffin Seaway, Caryapollenites generally has an LO in the latest Serravallian.

\section{Caryapollenites inelegans Nichols \& Ott 1978}

(Plate 18, figs 9, 10)

1978 Caryapollenites inelegans Nichols \& Ott, p. 105,106 , plate 2 , figs 7,8 .

Age. See 'Remarks' under the generic entry for Caryapollenites. Not plotted.

\section{Caryapollenites veripites (Wilson \& Webster 1946) Nichols \& Ott 1978}

(Plate 18, figs 11, 12)

1946 Carya veripites Wilson \& Webster, p. 276, fig. 14.

1978 Caryapollenites veripites (Wilson \& Webster) Nichols \& Ott, p. 106.

Age. See 'Remarks' under the generic entry for Caryapollenites. Not plotted. 


\section{Genus Cerebropollenites Nilsson 1958}

Type. Couper 1958, plate 30, fig. 8, as Tsugaepollenites mesozoicus.

1958 Cerebropollenites Nilsson, p. 72.

\section{Cerebropollenites mesozoicus (Couper 1958)} Nilsson 1958

1958 Tsugaepollenites mesozoicus Couper, p. 155, plate 30, figs 8-10.

1958 Cerebropollenites mesozoicus (Couper) Nilsson, p. 72.

Age. LO: Aptian.

\section{Genus Chenopodipollis Krutzsch 1966}

Type. Weyland \& Pflug 1957, plate 22, figs 18, 19, as Periporopollenites multiplex.

1966 Chenopodipollis Krutzsch, p. 35.

\section{Chenopodipollis sp.}

(Plate 18, fig. 17)

Age. LO: Miocene?

Genus Cicatricosisporites Potonié \& Gelletich 1933 Type. Potonié \& Gelletich 1933, plate 1, fig. 1, as Cicatricosisporites dorogensis, designated by Potonié (1956, p. 47).

1933 Cicatricosisporites Potonié \& Gelletich, p. 522.

1950 Mohrioidites Thiergart, p. 84 (name not validly published).

1951 Mohrioisporites Potonié, p. 144.

Remarks. Emendations for Cicatricosisporites have been proposed by Potonié (1966, p. 58) and Dettmann \& Clifford (1992, p. 289-291).

\section{Cicatricosisporites minutaestriatus (Bolkhovitina} 1961) Pocock 1964

1961 Pelletieria minutaestriata Bolkhovitina, p. 68, plate 20, fig. 1a-f; plate 21, fig. 3a-g.

1964 Cicatricosisporites minutaestriatus (Bolkhovitina) - Pocock, p. 159.

1971 Cicatricosisporites augustus Singh, p. 68, plate 7, figs 3-11; text-fig. 7M.
Age. LO: early Turonian.

\section{Cicatricosisporites ornatus Srivastava 1972}

(Plate 19, figs 1-4)

1972 Cicatricosisporites ornatus Srivastava, p. 9, plate 5, figs 3-11; plate 6 , figs $1-4$.

Age. LO: Priabonian.

Remarks. The forms studied here are very similar to the type material, described by Srivastava (1972) from the Maastrichtian of Alberta.

\section{Genus Cicatricososporites Pflug \& Thomson in} Thomson \& Pflug 1953

Type. Selling 1944, plate 4, fig. 44, as Schizaea? eocenica.

1953 Cicatricososporites Thomson \& Pflug, p. 61.

1959 Schizaeoisporites Krutzsch, p. 226.

Remarks. Jansonius \& Hills (1976) did not agree with Davies (1985) that Cicatricososporites was a junior homonym of Cicatricosisporites and retained the former as a separate genus.

Cicatricososporites eocenicus (Selling 1944) Jansonius \& Hills 1976

(Plate 18, fig. 5)

1944 Schizaea? eocenica Selling, p. 66, plate 4, fig. 44. 1950 Sporites pseudodorogensis Potonié - Thiergart, p. 84; name not validly published.

1951 Schizaeolsporites pseudodorogensis (Potonié) Potonié, p. 144, plate 20, fig. 19; generic name not validly proposed.

1953 Cicatricososporites pseudodorogensis (Potonié) Thomson \& Pflug, p. 61.

1976 Cicatricososporites eocenicus (Selling) Jansonius \& Hills, card 468.

Age. LO: middle Bartonian.

Remarks. Burden \& Hills (1989) recorded Cicatricososporites eocenicus from the Early Cretaceous, but the species is most common in the early Cenozoic and especially the Eocene. 


\section{Genus Compositoipollenites Potonié 1951 ex}

Potonié 1960

Type. Potonié 1934, plate 5, fig. 25, as Pollenites rhizophorus.

1951 Compositoipollenites Potonié, p. 138; name not validly published.

1960 Compositoipollenites Potonié, p. 105.

Compositoipollenites sp. B of Williams \& Brideaux 1975

(Plate 18, fig. 18)

1975 Compositoipollenites sp. B Williams \& Brideaux, plate 43, fig. 15.

Age. LO: Gelasian.

Remarks. Compositoipollenites sp. B of Williams \& Brideaux (1975) is very similar to the pollen of the extant genus Ambrosia, being tricolporate and ornamented with short (up to about $2 \mu \mathrm{m}$ ) conate spines that are distally pointed.

\section{Genus Corsinipollenites Nakoman 1965}

Type. Thiergart 1940, plate 7, fig. 1 as Pollenites oculus noctis.

\section{Corsinipollenites oculusnoctis (Thiergart 1940)}

Nakoman 1965

(Plate 18, figs 19, 20)

1940 Pollenites oculus noctis Thiergart, p. 47.

1965 Corsinipollenites oculusnoctis (Thiergart) Nakoman, p. 156.

Age. LO: Bartonian.

Remarks. Fossil pollen with this morphology have also been described under the modern plant name Jusseia.

Genus Extratriporopollenites Pflug in Thomson \& Pflug 1952 ex Pflug in Thomson \& Pflug 1953

Type. Pflug in Thomson \& Pflug 1953, plate 6, fig. 2, as Extratriporopollenites fractus.

1952 Extratriporopollenites Pflug in Thomson \& Pflug, p. 14, 16; name not validly published.

1953 Extratriporopollenites Pflug in Thomson \& Pflug 1952 ex Pflug in Thomson \& Pflug, p. 69.
Extratriporopollenites spp.

(Plate 19, figs 5-9)

Age. LO: Bartonian.

Genus Graminidites Cookson 1947 ex Potonié 1960

Type. Cookson 1947, plate 15, fig. 41, as Monoporites (Graminidites) media.

1947 Graminidites Cookson, p. 134; name not validly published.

1960 Graminidites Cookson ex Potonié, p. 111.

Graminidites sp. A. of Williams \& Brideaux 1975

(Plate 19, fig. 12)

1975 Graminidites spp. Williams \& Brideaux, plate 47, figs 9, 10.

Age. LO: latest Gelasian.

Genus Momipites Wodehouse 1933

Type. Momipites coryloides Wodehouse 1933, fig. 43.

1933 Momipites Wodehouse, p. 511.

Remarks. See 'Remarks' under the generic entry for Caryapollenites.

\section{Momipites annellus Nichols \& Ott 1978}

(Plate 18, figs 13, 14)

1978 Momipites annelus Nichols \& Ott, p. 103, plate 1, figs 22-25.

Age. See 'Remarks' under the generic entry for Caryapollenites. Not plotted.

\section{Momipites coryloides Wodehouse 1933}

(Plate 18, fig. 15)

1933 Momipites coryloides Wodehouse, p. 511, fig. 43.

Age. See 'Remarks' under the generic entry for Caryapollenites. Not plotted.

Genus Osmundacidites Couper 1953

Type. Couper 1953, plate 1, fig. 5, as Osmundacidites wellmanii. 
1953

Remarks. Osmundacidites is characterised by having a granulate to finely verrucate exine that is commonly irregularly organised.

\section{Osmundacidites wellmannii Couper 1953}

(Plate 20, fig. 1)

1953 Osmundacidites wellmannii Couper, p. 20, plate 1, fig. 5 .

1959 Baculatisporites wellmannii (Couper) Krutzsch, p. 142.

1964 Osmundacidisporites wellmannii (Couper) Levet-Carette, p. 98.

1968 Todisporites granulatus Tralau, p. 67, plate 7, fig. 1.

1972 Osmundacidites araucanus Volkheimer, p. 120 , plate 6 , figs $47-49$.

1986 Osmunda sp. in Williams, p. 83, plate 1, fig. 2.

Age. LO: Burdigalian.

Remarks. This species has a long range, starting in the Mesozoic, but its LO appears to be useful in the Labrador-Baffin Seaway region. We have established a Burdigalian LO; Williams (1986) considered that Osmunda sp. (= Osmundacidites wellmannii) has an LO in the middle to late Miocene. For a full synonymy listing of Osmundacidites wellmannii, see Fensome (1983, p. 323, 324).

\section{Genus Parviprojectus Mtchedlishvili in}

Samoilovitch \& Mtchedlishvili 1961 emend.

\section{Braman 2013}

Type. Samoilovitch \& Mtchedlishvili 1961, plate 73, fig. 2, as Parviprojectus reticulatus.

1961 Parviprojectus Mtchedlishvili in Samoilovitch \& Mtchedlishvili, p. 225.

2013 Parviprojectus Mtchedlishvili in Samoilovitch \& Mtchedlishvili - emend. Braman, p. 129.

Remarks. Following Braman (2013), Parviprojectus is considered to comprise triprojectate pollen that are isopolar and have a reticulate wall.

\section{Parviprojectus reticulatus Mtchedlishvili in \\ Samoilovitch \& Mtchedlishvili 1961}

(Plate 17, fig. 16)
1961 Parviprojectus reticulatus Mtchedlishvili in Samoilovitch \& Mtchedlishvili, p. 226, 227, plate 73 , figs 2,3 .

1961 Aquilapollenites reticulatus Stanley, p. 348, 349, plate 8, figs $1-12$.

1970 Integricorpus reticulatus (Mtchedlishvili) Stanley, p. 29.

1970 Aquilapollenites (Parviprojectus) reticulatus (Mtchedlishvili) - Kedves \& Király, p. 67.

Remarks. This species is characterised by its fine reticulate ornament. The above synonymy follows that of Braman (2013, p. 148), with only nomenclaturally significant entries included.

Age. LO: not determined; not plotted. The illustrated specimen is from late Paleocene strata in Rut H-11. According to Braman (2013), this species ranges from the Campanian to early Paleocene, with a 'provisional' occurrence in the late Eocene. The latter may be reworked, as could be the present occurrence.

\section{Genus Parvisaccites Couper 1958}

Type: Couper 1958, plate 29, figs 5, 6, as Parvisaccites radiatus.

1958 Parvisaccites Couper, p. 154.

\section{Parvisaccites amplus Brenner 1963}

1963 Parvisaccites amplus Brenner, p. 78, 79, plate 28, fig. 1a, b; plate 29, fig. 1a, b.

Age. LO: Aptian.

\section{Parvisaccites radiatus Couper 1958}

1958 Parvisaccites radiatus Couper, p. 154, plate 29, figs 5-8; plate 30 , figs $1,2$.

Age. LO: Aptian.

Genus Periporopollenites Pflug \& Thomson in Thomson \& Pflug 1953

Type. Potonié 1931, plate 2, fig. 1, as Pollenites stigmosus.

1953 Periporopollenites Pflug \& Thomson in Thomson \& Pflug, p. 111.

1960 Liquidambarpollenites Raatz 1937 ex Potonié, p. 134. 


\section{Periporopollenites sp.}

(Plate 19, figs 10, 11)

Age. LO: early? Miocene. Not plotted.

\section{Genus Pistillipollenites Rouse 1962}

Type. Rouse 1962, plate 1, figs 10, 12, as Pistillipollenites macgregorii.

1962 Pistillipollenites Rouse, p. 206.

Remarks. The distinctive characteristic of this triporate pollen grain is the pistil-like or bulbose ornamentation that covers the exine.

\section{Pistillipollenites macgregorii Rouse 1962}

(Plate 19, figs 13, 14)

1962 Pistillipollenites macgregorii Rouse, p. 206, plate 1, figs 8-12.

Age. LO: Bartonian.

Genus Quercoidites Potonié et al. 1950 ex Potonié 1960

Type. Potonié 1931, plate 2, fig. 19, as Pollenites henrici.

1950 Quercoidites Potonié et al., p. 54; name not validly published.

1960 Quercoidites Potonié et al. ex Potonié, p. 92.

Remarks. The exine of this ovoidal, tricolpate pollen grain is usually granulate to scabrate. The colpi reach almost to the poles.

\section{Quercoidites sp.}

(Plate 19, figs 15, 16)

1986 Quercus form A of Williams, p. 83, plate 1, fig. 8.

Age. LO: Frequent in latest Messinian.

Remarks. This is a finely granular form of Quercoidites, also found by Williams (1986) and called Quercus form A. Williams found that the LO of this form was in her Fagus granulata Zone, which she dated as early Miocene. Quercoidites sp. differs from Quercoidites sp. A of Williams \& Brideaux (1975) (equivalent to Quercus form B of Williams 1986) in its much finer ornament.
Genus Rugubivesiculites Pierce 1961

Type. Pierce 1961, plate 2, fig. 57, as Rugubivesiculites convolutes.

1961 Rugubivesiculites Pierce, p. 39.

Remarks. Rugubivesiculites is a bivesiculate pollen with a distinctive rugulate ornamentation on the proximal surface of the central body.

\section{Rugubivesiculites spp.}

(Plate 20, fig. 2)

Age. LO: Turonian.

Remarks. No attempt was made to speciate the specimens of Rugubivesiculites seen in the Labrador Margin and offshore West Greenland samples.

\section{Genus Tiliaepollenites Potonié 1931}

Type. Potonié 1931, fig. 14, as Tiliaepollenites indupitabilis.

1931 Tiliaepollenites Potonié, p. 4.

1938 Tiliaepollenites Raatz, p. 27.

1953 Intratriporopollenites Pflug \& Thomson in Thomson \& Pflug, p. 87.

Tiliaepollenites crassipites (Wodehouse 1933) comb. nov.

(Plate 19, figs 17, 18)

1933 Tilia crassipites Wodehouse, p. 515, fig. 48.

1969 Tilliaepollenites crassipites (Wodehouse) Penny, p. 355 (combination not validly published, basionym not fully referenced).

1975 Bombacacidites sp. A Williams \& Brideaux, plate 46, fig. 10.

1986 Tilia crassipites Williams, plate 2, fig. 1.

Age. LO: Serravallian.

Remarks. A search of the Palynodata database (Palynodata Inc. \& White 2008) provided no indication of a previous formal transfer of this species to Tiliaepollenites.

\section{Tiliaepollenites sp. A}

(Plate 19, figs 19, 20)

Description. This form is distinctive in its possession of a pad-like thickening at the inner end of each colpus. 
Age. LO: early? Miocene (not well constrained). Not plotted.

\section{Genus Translucentipollis Khlonova 1961}

Type. Khlonova 1961, plate 16, fig. 121, as Aquilapollenites plicatilis.

1961 Translucentipollis Khlonova, p. 89.

1966 Translucentipollis Khlonova - Srivastava, p. 546.

Remarks. Following Braman (2013, p. 13), Translucentipollis is considered to comprise isopolar triprojectate pollen with reduced polar projections and a more or less smooth surface.

\section{Translucentipollis contiguus (Tschudy 1969) \\ Braman 2013}

(Plate 17, fig. 13)

Remarks. The specimen illustrated has very fine granulae to short and delicate rugulae that are barely discernible in optical section. We consider that this wall surface fits within the granular to scabrate range of Translucentipollis contiguous.

Age. LO: not determined. Not plotted.

\section{Genus Wodehouseia Stanley 1961}

Type. Stanley 1961, plate 1, figs 1-3, as Wodehouseia spinata.

1961 Wodehouseia Stanley, p. 157.

Remarks. Wodehouseia is included in the 'oculata' pollen, which Khlonova (1962, p. 306) defined as pollen grains with two pairs of apertures that are located close to the tips of the two long sides. Wiggins (1976) gave a thorough review of various genera in the group, including Wodehouseia.

\section{Wodehouseia spinata Stanley 1961}

(Plate 20, fig. 3)

1961 Wodehouseia spinata Stanley, p. 157, 158, 160 , plate 1 , figs $1-12$.

Age. LO: latest Maastrichtian.
Genus Zlivisporis Pacltová 1961

Type. Pacltová 1961, plate 2, figs 1-3, as Zlivisporis blanensis.

1961 Zlivisporis Pacltová, p. 40.

1961 Seductisporites Khlonova, p. 56.

1962 Rouseisporites Pocock, p. 52.

Remarks. The reticulum developed on the distal surface is never fine and is often incomplete.

\section{Zlivisporis spp.}

(Plate 20, figs 4-8)

Age. LO: early Rupelian.

Remarks. Specimens of Zlivisporis from the LabradorBaffin Seaway region are variable, especially in the nature of the surface reticulum, and are thus difficult to speciate.

\section{Genus Zonalapollenites Pflug in Thomson \& Pflug} 1953

Type. Potonié 1931, fig. 2, as Sporonites igniculus.

1934 Tsugaepollenites Potonié \& Venitz, p. 17; name not validly published.

1958 Zonalapollenites Pflug in Thomson \& Pflug, p. 66.

1958 Tsugaepollenites Potonié \& Venitz ex Potonié, p. 48.

Remarks. This genus is characterised by the numerous small, distinct equatorial sacs or vesiculae. Sometimes the polar regions may be covered with greatly reduced sacs. Jansonius \& Hills (1976, card 3265) recognised that Tsugaepollenites is an obligate junior synonym of Zonalapollenites.

\section{Zonalapollenites igniculus (Potonié 1931)} Thomson \& Pflug 1953

(Plate 20, figs 9-11)

1931 Sporonites igniculus Potonié, p. 556, fig. 2.

1934 Tsugaepollenites igniculus (Potonié) - Potonié $\&$ Venitz, p. 17; name not validly published.

1953 Zonalapollenites igniculus (Potonié ex Pflug) Thomson \& Pflug, p. 66.

Age. LO: latest Gelasian. 


\section{Fungal elements}

Remarks. All fungal spores are grouped together but several different morphologies are recorded, including those shown in the accompanying illustrations (Plate 20, figs 12-20). Fungal spores occur sporadically throughout the sections studied, but peaks were noted in the Lutetian and Ypresian.

\section{Acknowledgements}

During the gestation of this paper of over a decade, we have had the unwavering support of our two institutions, the Geological Survey of Denmark and Greenland (GEUS) and the Geological Survey of Canada
(Atlantic) (GSCA), part of the Earth Sciences Sector (ESS) of Natural Resources Canada. We are also grateful for fruitful discussions with, and feedback from, Kate Dickie of GSCA, Lotte M. Larsen and Gunver K. Pedersen of GEUS, Stefan Piasecki of the Geological Museum, Natural History Museum of Denmark, University of Copenhagen. We are grateful to Jennifer Galloway, Martin Pearce, Jim Riding and Art Sweet for helpful reviews that led to important improvements of the manuscript. We also extend our thanks Bernie Crilley and Bill MacMillan (GSC), and Annette Ryge and Dorthe Salomonsen (GEUS) for processing samples. 


\section{References}

Agelopoulos, J. 1964: Hystrichostrogylon membraniphorum n.g. n.sp. aus dem Heiligenhafener Kieselton (Eozän). Neues Jahrbuch für Geologie und Paläontologie, Monatshefte 11, 673-675.

Agelopoulos, J. 1967: Hystrichosphären, Dinoflagellaten und Foraminiferen aus dem eozänen Kieselton von Heiligenhafen, Holstein. Dissertation des Grades eines Dokters der mathematischnaturwissenschaftlichen Fakultät der Eberhard-Karls-Universität, Tübingen 74 pp. (Published thesis.)

Alberti, G. 1959: Zur Kenntnis der Gattung Deflandrea Eisenack (Dinoflag.) in der Kreide und im Alttertiär Nord- und Mitteldeutschlands. Mitteilungen aus dem Geologischen Staatsinstitut in Hamburg 28, 93-105.

Alberti, G. 1961: Zur Kenntnis mesozoischer und alttertiärer Dinoflagellaten und Hystrichosphaerideen von Nord- und Mitteldeutschland sowie einigen anderen europäischen Gebieten. Palaeontographica Abteilung A 116, 1-58.

Anderson, R.Y. 1960: Cretaceous-Tertiary palynology, eastern side of the San Juan Basin, New Mexico. New Mexico Bureau of Geology and Mineral Resources Memoir 6, 1-59.

Artzner, D.G. \& Dörhöfer, G. 1978: Taxonomic note: Lejeunecysta nom. nov. pro Lejeunia Gerlach 1961 emend. Lentin and Williams 1976 - dinoflagellate cyst genus. Canadian Journal of Botany 56, 1381-1382.

Balme, B.E. 1957: Spores and pollen grains from the Mesozoic of Western Australia. Commonwealth Scientific and Industrial Research Organization (Australia), Coal Research Section, Reference T.C. 25, 1-48.

Barke, J., Abels, H.A., Sangiorgi, F., Greenwood, D.R., Sweet, A.R., Donders, T., Reichart, G-J., Lotter, A.F. \& Brinkhuis, H. 2011: Orbitally forced Azolla blooms and Middle Eocene Arctic hydrology: clues from palynology. Geology 39(5), 427-430.

Barke, J. et al. 2012: Coeval Eocene blooms of the freshwater fern Azolla in and around Arctic and Nordic seas. Palaeogeography, Palaeoclimatology, Palaeoecology 337-338, 108-119.

Batten, D.J. 1996: Chapter 7C. Colonial Chlorococcales. In: Jansonius, J. \& McGregor, D.C. (eds): Palynology: principles and applications. American Association of Stratigraphic Palynologists Foundation, 1, 191-203.

Batten, D. \& Lister, J. 1988: Evidence of freshwater dinoflagellates and other algae in the English Wealden (Early Cretaceous). Cretaceous Research 9, 171-179.

Below, R. 1981: Dinoflagellaten-Zysten aus dem oberen Hauterive bis unteren Cenoman Süd-West-Marokkos. Palaeontographica Abteilung B 176, 1-145.

Benedek, P.N. 1972: Phytoplanktonten aus dem Mittel- und Oberoligozän von Tönisberg (Niederrheingebiet). Palaeontographica Abteilung B 137, 1-71.

Benedek, P.N. \& Gocht, H. 1981: Thalassiphora pelagica (Dinoflagellata, Tertiär): electronenmikroskopische Untersuchung und Gedanken zur Paläobiologie. Palaeontographica Abteilung B 180, 39-64.
Benedek, P.N. \& Sarjeant, W.A.S. 1981: Dinoflagellate cysts from the Middle and Upper Oligocene of Tönisberg (Niederrheingebiet): a morphological and taxonomic restudy. Nova Hedwigia 35, 313-356.

Benson, D.G. 1976: Dinoflagellate taxonomy and biostratigraphy at the Cretaceous-Tertiary boundary, Round Bay, Maryland. Tulane Studies in Geology and Paleontology 12(4), 169-233.

Bint, A.N. 1986: Fossil Ceratiaceae: a restudy and new taxa from the mid-Cretaceous of the western interior, U.S.A. Palynology 10, 135-180.

Bolkhovitina, N.A. 1953: Spore and pollen characteristic of Cretaceous deposits of Central regions of the USSR. Trudy Instituta Geologicheskikh Nauk, Moscow, Akademiya Nauk, SSSR 145(61), 183 pp.

Bolkhovitina, N.A. 1961: Fosssil and Recent spores of the family Schizeaceae. Academii Nauk USSR. Trudy Geologicicheskii Institut, Akademiya Nauk, SSSR 40, 1-175.

Braman, D.R. 2013: Triprojectate pollen occurrence in the Western Canada Sedimentary Basin and the group's global relationships. Royal Tyrrell Museum of Palaeontology Contribution Series 1, 538 pp.

Brenner, G.J. 1963: The spores and pollen of the Potomac Group of Maryland. Maryland Department of Geology, Mines and Water Resources, Bulletin 27, 1-215.

Brenner, G.J. 1968: Middle Cretaceous spores and pollen from northeastern Peru. Pollen et Spores 10 (2), 341-383.

Brenner, W. 1988: Dinoflagellaten aus dem unteren Malm (oberer Jura) von Süddeutschland; Morphologie, Ökologie, Stratigraphie. Tübinger Mikropaläontologische Mitteilungen 6, 1-116.

Brideaux, W.W. 1971: Palynology of the Lower Colorado Group, central Alberta, Canada. I. Introductory remarks. Geology and microplankton studies. Palaeontographica Abteilung B 135(36), 53-114.

Brideaux, W.W. 1975: Taxonomic note: redefinition of the genus Broomea and its relationship to Batioladinium gen. nov. (Cretaceous). Canadian Journal of Botany 53(12), 1239-1243.

Brideaux, W.W. 1977: Taxonomy of Upper Jurassic-Lower Cretaceous microplankton from the Richardson Mountains, District of Mackenzie, Canada. Geological Survey of Canada Bulletin 281, 1-89.

Brideaux, W.W. \& McIntyre, D.J. 1975: Miospores and microplankton from Aptian-Albian rocks along Horton River, District of Mackenzie. Geological Survey of Canada Bulletin 252, 1-85.

Brinkhuis, H. \& Schiøler, P. 1996: Palynology of the Geulhemmerberg Cretaceous/Tertiary boundary section (Limburg, SE Netherlands). Geologie en Mijnbouw 75(2/3), 193-213.

Brosius, M. 1963: Plankton aus dem nordhessischen Kasseler Meeressand (Oberoligozän). Zeitschrift der Deutschen Geologischen Gesellschaft 114(1), 32-56.

Bujak, J.P. 1976: An evolutionary series of Late Eocene dinoflagel- 
late cysts from southern England. Marine Micropaleontology 1, 101-117.

Bujak, J.P. 1979: Proposed phylogeny of the dinoflagellates Rhombodinium and Gochtodinium. Micropaleontology 25(3), 308324.

Bujak, J.P. 1984: Cenozoic dinoflagellate cysts and acritarchs from the Bering Sea and northern North Pacific, D.S.D.P. Leg 19. Micropaleontology 30(2), 180-212.

Bujak, J.P. 1994: New dinocyst taxa from the Eocene of the North Sea. Journal of Micropalaeontology 13, 119-131.

Bujak, J.P. \& Davies, E.H. 1983: Modern and fossil Peridiniineae. American Association of Stratigraphic Palynologists, Contributions Series 13, 203 pp.,

Bujak, J.P. \& Matsuoka, K. 1986: Taxonomic reallocation of Cenozoic dinoflagellate cysts from Japan and the Bering Sea. Palynology 10, 235-241.

Bujak, J.P., Downie, C., Eaton, G.L. \& Williams, G.L. 1980: IV. Taxonomy of some Eocene dinoflagellate cyst species from southern England. In: Bujak, J.P. et al. (eds): Dinoflagellate cysts and acritarchs from the Eocene of southern England. Special Papers in Palaeontology 24, 26-36.

Burden, E.T. \& Hills, L.V. 1989: Illustrated key to genera of Lower Cretaceous terrestrial palynomorphs (exluding megaspores) of western Canada. American Association of Stratigraphic Palynologists Contribution Series 21, 1-147.

Burden, E. \& Langille, A. 1990: Stratigraphy and sedimentology of Cretaceous and Paleocene strata in half-grabens on the southeast coast of Baffin Island, Northwest Territories. Bulletin of Canadian Petroleum Geology 38(2), 185-196.

Burgess, J.D. 1971: Palynological interpretation of Frontier environments in central Wyoming. Geoscience and Man 3, 69-82.

Bütschli, O. 1885: Erster Band. Protozoa. In: Dr. H.G. Bronn's Klassen und Ordnungen des Thier-Reichs, wissenschaftlich dargestellt in Wort und Bild, 865-1088. C.F. Winter'sche Verlagsbuchhandlung, Leipzig and Heidelberg, Germany.

Chalmers, J. \& Pulvertaft, T. 2001: Development of the continental margins of the Labrador Sea: a review. In: Wilson, R. et al. (eds): Non-volcanic rifting of continental margins: a comparison of evidence from land and sea. Geological Society Special Publications (London) 187, 77-105.

Chalmers, J.A., Pulvertaft, T.C.R., Christiansen, F.G., Larsen, H.C., Laursen, K.H. \& Ottesen, T.G. 1993: The southern West Greenland continental margin: rifting history, basin development and petroleum potential. In: Parker, J.R. (ed.): Petroleum geology of Northwest Europe: Proceedings of the 4th conference, 915-931. London: Geological Society.

Clarke, R.F.A. \& Verdier, J.-P. 1967: An investigation of microplankton assemblages from the Chalk of the Isle of Wight, England. Verhandelingen der Koninklijke Nederlandse Akademie van Wetenschappen, Afdeeling Natuurkunde, Eerste Reeks 24(3), 1-96.

Cookson, I.C. 1947: Fossil fungi from Tertiary deposits in the southern hemisphere. Part I. Proceedings of the Linnean Society of New South Wales 72(3-4), 207-214.

Cookson, I.C. 1956: Additional microplankton from Australian
Late Mesozoic and Tertiary sediments. Australian Journal of Marine and Freshwater Research 7(1), 183-191.

Cookson, I.C. 1965: Cretaceous and Tertiary microplankton from south-eastern Australia. Proceedings of the Royal Society of Victoria 78(1), 85-93.

Cookson, I.C. \& Eisenack, A. 1958: Microplankton from Australian and New Guinea Upper Mesozoic sediments. Proceedings of the Royal Society of Victoria 70(1), 19-79.

Cookson, I.C. \& Eisenack, A. 1960a: Microplankton from Australian Cretaceous sediments. Micropaleontology 6(1), 1-18.

Cookson, I.C. \& Eisenack, A. 1960b: Upper Mesozoic microplankton from Australia and New Guinea. Palaeontology 2(2), 243261.

Cookson, I.C. \& Eisenack, A. 1961a: Tertiary microplankton from the Rottnest Island Bore, Western Australia. Journal of the Royal Society of Western Australia 44, 39-47.

Cookson, I.C. \& Eisenack, A. 1961b: Upper Cretaceous microplankton from the Belfast No. 4 Bore, southwestern Victoria. Proceedings of the Royal Society of Victoria, 74(1), 69-76.

Cookson, I.C. \& Eisenack, A. 1962: Additional microplankton from Australian Cretaceous sediments. Micropaleontology 8(4), 485-507.

Cookson, I.C. \& Eisenack, A. 1965a: Microplankton from the Dartmoor Formation, southwestern Victoria. Proceedings of the Royal Society of Victoria 79, 133-137.

Cookson, I.C. \& Eisenack, A. 1965b: Microplankton from the Browns Creek Clays, southwestern Victoria. Proceedings of the Royal Society of Victoria 79, 119-131.

Cookson, I.C. \& Eisenack, A. 1968: Microplankton from two samples from Gingin Brook No. 4 Borehole, Western Australia. Journal of the Royal Society of Western Australia 51, 110-122.

Cookson, I.C. \& Eisenack, A. 1969: Some microplankton from two bores at Balcatta, Western Australia. Journal of the Royal Society of Western Australia 52, 3-8.

Cookson, I.C. \& Eisenack, A. 1970a: Die Familie der Lecaniellaceae n. fam. - fossile Chlorophyta, Volvocales? Neues Jahrbuch für Geologie und Paläontologie, Monatshefte 6, 321-325.

Cookson, I.C. \& Eisenack, A. 1970b: Cretaceous microplankton from the Eucla Basin, Western Australia. Proceedings of the Royal Society of Victoria 83(2), 137-157.

Cookson, I.C. \& Manum, S.B. 1964: On Deflandrea victoriensis n. sp. and D. tripartita Cookson and Eisenack, and related species. Proceedings of the Royal Society of Victoria 77, 521-524.

Corradini, D. 1973: Non-calcareous microplankton from the Upper Cretaceous of the northern Apennines. Bollettino della Società paleontologica italiana 11, 119-197.

Costa, L.I. \& Downie, C. 1976: The distribution of the dinoflagellate Wetzeliella in the Palaeogene of north-western Europe. Palaeontology 19, 591-614.

Costa, L.I. \& Downie, C. 1979: The Wetzeliellaceae; Palaeogene dinoflagellates. In: Proceedings of the 4th International Palynological Conference, Lucknow (1976-1977) 2, 34-46.

Couper, R.A. 1953: Upper Mesozoic and Cainozoic spores and pollen grains from New Zealand. New Zealand Geological Survey, Paleontological Bulletin 22, 5-77. 
Couper, R.A. 1958: British Mesozoic microspores and pollen grains - a systematic and stratigraphic study. Palaeontographica Abteilung B, Paläophytologie 103, 75-179.

Dam, G., Pedersen, G.K., Sønderholm, M., Midtgaard, H.H., Larsen, L.M., Nøhr-Hansen, H. \& Pedersen, A.K. 2009: Lithostratigraphy of the Cretaceous-Paleocene Nuussuaq Group, Nuussuaq Basin, West Greenland. Geological Survey of Denmark and Greenland Bulletin 19, 171 pp.

Damassa, S.P. 1997: Dinoflagellate cysts without walls: Evittosphaerula paratabulata Manum, 1979 and Chaenosphaerula magnifica gen. et sp. nov. from Deep Sea Drilling Project Site 338, Norwegian Sea. Review of Palaeobotany and Palynology 98, 159-176.

Davey, R.J. 1969a: Non-calcareous microplankton from the Cenomanian of England, northern France and North America, part I. British Museum (Natural History). Geology. Bulletin 17, 103180.

Davey, R.J. 1969b: Some dinoflagellate cysts from the Upper Cretaceous of northern Natal, South Africa. Palaeontologia Africana 12, 1-23.

Davey, R.J 1969c: The evolution of certain Upper Cretaceous hystrichospheres from South Africa. Palaeontologia Africana 12, $25-51$.

Davey, R.J. 1970: Non-calcareous microplankton from the Cenomanian of England, northern France and North America, part II. British Museum (Natural History). Geology. Bulletin 18(8), 333-397.

Davey, R.J. 1974: Dinoflagellate cysts from the Barremian of the Speeton Clay, England. In: Symposium on Stratigraphic Palynology: Birbal Sahni Institute of Palaeobotany, Special Publication 3, 41-75.

Davey, R.J. 1978: Marine Cretaceous palynology of Site 361, DSDP Leg 40, off southwestern Africa. In: Bolli, H.M. et al. (eds): Deep Sea Drilling Project, Washington, Initial Reports 40, 883-914.

Davey, R.J. 1979: Marine Apto-Albian palynomorphs from Holes 400A and 402A, IPOD Leg 48, northern Bay of Biscay. In: Montadert, L. et al. (eds): Deep Sea Drilling Project, Washington, Initial Reports 48, 547-577.

Davey, R.J. \& Verdier, J.-P. 1971: An investigation of microplankton assemblages from the Albian of the Paris Basin. Verhandelingen der Koninklijke Nederlandse Akademie van Wetenschappen, Afdeeling Natuurkunde, Eerste Reeks 26, 1-58.

Davey, R.J. \& Verdier, J.-P. 1973: An investigation of microplankton assemblages from latest Albian (Vraconian) sediments. Revista española de micropaleontologia 5, 173-212.

Davey, R.J. \& Williams, G.L. 1966a: V. The genus Hystrichosphaeridium and its allies. In: Davey, R.J. et al. (eds): Studies on Mesozoic and Cainozoic dinoflagellate cysts. Bulletin of the British Museum (Natural History). Geology. Supplement 3, 53-106.

Davey, R.J. \& Williams, G.L. 1966b: IV. The genera Hystrichosphaera and Achomosphaera. In: Davey, R.J. et al. (eds): Studies on Mesozoic and Cainozoic dinoflagellate cysts. Bulletin of the British Museum (Natural History). Geology. Supplement 3, $28-52$.
Davey, R.J. \& Williams, G.L. 1969: Generic reallocations. In: Davey, R.J. et al. (eds): Appendix to Studies on Mesozoic and Cainozoic dinoflagellate cysts. Bulletin of the British Museum (Natural History). Geology. Appendix to Supplement 3, 4-7.

Davey, R.J., Downie, C., Sarjeant, W.A.S. \& Williams, G.L. 1966: VII. Fossil dinoflagellate cysts attributed to Baltisphaeridium. In: Davey, R.J. et al. (eds): Studies on Mesozoic and Cainozoic dinoflagellate cysts. Bulletin of the British Museum (Natural History). Geology. Supplement 3, 157-175.

Davey, R.J., Downie, C., Sarjeant, W.A.S. \& Williams, G.L. 1969: Generic reallocations. In: Davey, R.J. et al. (eds): Appendix to Studies on Mesozoic and Cainozoic dinoflagellate cysts. Bulletin of the British Museum (Natural History). Geology. Appendix to Supplement 3, 15-17.

Davies, E.H. 1985: The anemiacean, schizaeacean and related spores: an index to genera and species. Canadian Technical Report of Hydrography and Ocean Sciences 67, 218 pp.

de Coninck, J. 1965: Microfossiles planctoniques du sable Yprésien à Merelbeke. Dinophyceae et Acritarcha. Mémoires de l'Académie royale des sciences, des lettres et des beaux-arts de Belgique, Classe des sciences, Collection in- $8^{\circ}, \mathbf{3 6}(2), 1-55$.

de Coninck, J. 1969: Dinophyceae et Acritarcha de l'Yprésien du sondage de Kallo. Mémoires de l'Institut royal des sciences naturelles de Belgique 161, 1-67.

de Coninck, J. 1975: Microfossiles à paroi organique de l'Yprésien du Bassin Belge. Service géologique de Belgique Professional Paper 12, 1-151.

de Coninck, J. 1977: Organic walled microfossils from the Eocene of the Woensdrecht borehole, southern Netherlands. Mededelingen Rijks Geologische Dienst, Nieuwe Serie 28(3), 33-64.

Deflandre, G. 1934: Sur les microfossiles d'origine planctonique, conservés à l'état de matière organique dans les silex de la craie. Comptes rendus hebdomadaires des séances de l'Académie des sciences 199, 966-968.

Deflandre, G. 1935: Considérations biologiques sur les microorganisms d'origine planctonique conservés dans les silex de la craie. Bulletin biologique de la France et de la Belgique 69, 213-244.

Deflandre, G. 1936: Microfossiles des silex crétacés. Première partie. Généralités. Flagellés. Annales de paléontologie 25, 151191.

Deflandre, G. 1937: Microfossiles des silex crétacés. Deuxième partie. Flagellés incertae sedis. Hystrichosphaeridés. Sarcodinés. Organismes divers. Annales de paléontologie 26, 51-103 (al. 3-55).

Deflandre, G. 1942: Sur les hystrichosphères des calcaires siluriens de la Montagne Noire. Comptes rendus hebdomadaires des séances de l'Académie des sciences 215(20), 475-476.

Deflandre, G. 1943: Sur quelques nouveaux dinoflagellés des silex crétacés. Bulletin de la Société géologique de France, 5e Série 13, 499-509.

Deflandre, G. 1946: Fichier micropaleàontologique général, série 6. Hystrichosphaerides II. Espèces du Secondaire et du Tertiaire. Archives originales, Centre de documentation; Centre National de la Recherche Scientifique (France) 235(1-5), cards 860-1019. 
Deflandre, G. \& Cookson, I.C. 1954: Sur le microplancton fossile conservé dans diverses roches sédimentaires australiennes s'étageant du Crétacé inférieur au Miocène supérieur. Comptes rendus hebdomadaires des séances de l'Académie des sciences 239, 1235-1238.

Deflandre, G. \& Cookson, I.C. 1955: Fossil microplankton from Australian late Mesozoic and Tertiary sediments. Australian Journal of Marine and Freshwater Research 6(2), 242-313.

Deflandre, G. \& Courteville, H. 1939: Note préliminaire sur les microfossiles des silex crétacés du Cambrésis. Bulletin de la société française de microscopie 8, 95-106.

Dettmann, M.E. 1963: Upper Mesozoic microfloras from southeastern Australia. Proceedings of the Royal Society of Victoria 77(1), 1-148.

Dettmann, M.E. \& Clifford, H.T. 1992: Phylogeny and biogeography of Ruffordia, Mohria and Anemia (Schizaeaceae) and Ceratopteris (Pteridaceae): evidence from in situ and dispersed spores. Alcheringa 16(4), 269-314.

Dev, S. 1961: The fossil flora of the Jabalpur Series-3, spores and pollen grains. Palaeobotanist 8(1), 43-56.

de Vernal, A. \& Mudie, P.J. 1989: Pliocene and Pleistocene palynostratigraphy at the ODP Sites 646 and 647, eastern and southern Labrador Sea. In: Srivastava, S.P. et al. (eds): Ocean Drilling Program Proceedings, Scientific Results 105, 401-422.

de Verteuil, L. \& Norris, G. 1996: Miocene dinoflagellate stratigraphy and systematics of Maryland and Virginia. Micropaleontology 42, Supplement I-VIII, 1-172.

Dickie, K., Keen, C.E., Williams, G.L. \& Dehler, S.A. 2011: Tectonostratigraphic evolution of the Labrador margin, Atlantic Canada. Marine \& Petroleum Geology 28, 1663-1675.

Dörhöfer, G. \& Davies, E.H. 1980: Evolution of archeopyle and tabulation in rhaetogonyaulacinean dinoflagellate cysts. Miscellaneous Publication 91 pp. Royal Ontario Museum, Life Sciences Division, Toronto, Canada.

Döring, H. 1961: Planktonartige Fossilien des Jura/Kreide-Grenzbereichs der Bohrungen Werle (Mecklenburg). Geologie 10(32), 110-121.

Downie, C. \& Sarjeant, W.A.S. 1965: Bibliography and index of fossil dinoflagellates and acritarchs. Geological Society of America Memoir 94, 180 pp.

Doyle, J.A., Jardiné, S. \& Doerenkamp, A. 1982: Afropollis, a new genus of early angiosperm pollen, with notes on the Cretaceous palynostratigraphy and paleoenvironments of northern Gondwana. Bulletin des Centres de recherches exploration-production Elf-Aquitaine 6(1), 39-117.

Drugg, W.S. 1967: Palynology of the Upper Moreno Formation (Late Cretaceous-Paleocene) Escarpado Canyon, California. Palaeontographica Abteilung B 120(1-4), 1-71.

Drugg, W.S. 1970: Some new genera, species, and combinations of phytoplankton from the Lower Tertiary of the Gulf Coast, U.S.A. Proceedings of the North American Paleontological Convention, Chicago, September 1969, part G, 809-843.

Drugg, W.S. 1978: Some Jurassic dinoflagellate cysts from England, France and Germany. Palaeontographica Abteilung B 168(1-3), 61-79.
Drugg, W.S. \& Loeblich, A.R., Jr. 1967: Some Eocene and Oligocene phytoplankton from the Gulf Coast, U.S.A. Tulane Studies in Geology 5(4), 181-194.

Duxbury, S. 1980: Barremian phytoplankton from Speeton, east Yorkshire. Palaeontographica Abteilung B 173(4-6), 107-146.

Duxbury, S. 1983: A study of dinoflagellate cysts and acritarchs from the Lower Greensand (Aptian to Lower Albian) of the Isle of Wight, southern England. Palaeontographica Abteilung B 186(1-3), 18-80.

Duxbury, S. 2002: Two new Early Cretaceous dinocyst species from the Central North Sea Basin. Journal of Micropalaeontology 21, 75-80.

Eaton, G.L. 1971: A morphogenetic series of dinoflagellate cysts from the Bracklesham Beds of the Isle of Wight, Hampshire, England. Proceedings of the 2nd Planktonic Conference, Rome, 1970, 355-379.

Eaton, G.L. 1976: Dinoflagellate cysts from the Bracklesham Beds (Eocene) of the Isle of Wight, southern England. British Museum (Natural History). Geology. Bulletin 26, 227-332.

Eaton, G.L., Fensome, R.A., Riding, J.B. \& Williams, G.L. 2001: Re-evaluation of the status of the dinoflagellate cyst genus Cleistosphaeridium. Neues Jahrbuch für Geologie und Paläontologie Abhandlungen 219(1-2), 171-205.

Edwards, L.E. 2001: Dinocyst biostratigraphy of Tertiary sediments from five cores from Screven and Burke counties, Georgia. In: Edwards, L.E. (ed.): Geology and paleontology of five cores from Screven and Burke counties, eastern Georgia. U.S. Geological Survey Professional Paper 1603-G, G1-G25. U.S. Department of the Interior. U.S. Geological Survey.

Edwards, L.E. \& Bebout, J.W. 1981: Emendation of Phthanoperidinium Drugg and Loeblich 1967, and a description of $P$. brooksii sp. nov. from the Eocene of the mid-Atlantic outer continental shelf. Palynology 5, 29-41.

Ehrenberg, C.G. 1838: Über das Massenverhältniss der jetzt lebenden Kiesel-Infusorien und über ein neues Infusorien-Conglomerat als Polierschiefer von Jastraba in Ungarn. Königlich Akademie der Wissenschaften zu Berlin Abhandlungen 1836(1), 109-135.

Eisenack, A. 1938: Die Phosphoritknollen der Bernsteinformation als Überlieferer tertiären Planktons. Schriften der PhysikalischÖkonomischen Gesellschaft zu Königsberg 70(2), 181-188.

Eisenack, A. 1954: Mikrofossilien aus Phosphoriten des samländischen Unteroligozäns und über die Einheitlichkeit der Hystrichosphaerideen. Palaeontographica Abteilung A 105(3-6), 49-95.

Eisenack, A. 1958: Mikroplankton aus dem norddeutschen Apt, nebst einigen Bemerkungen über fossile Dinoflagellaten. Neues Jahrbuch für Geologie und Paläontologie Abhandlungen 106(3), 383-422.

Eisenack, A. 1963a: Cordosphaeridium n.g., ex Hystrichosphaeridium, Hystrichosphaeridea. Neues Jahrbuch für Geologie und Paläontologie Abhandlungen 118, 260-265.

Eisenack, A. 1963b: Hystrichosphären. Biological Reviews 38, 107139.

Eisenack, A. \& Cookson, I.C. 1960: Microplankton from Australian Lower Cretaceous sediments. Proceedings of the Royal Society of Victoria 72, 1-11. 
Eisenack, A. \& Gocht, H. 1960: Neue Namen für einige Hystrichosphären der Bernsteinformation Ostpreussens. Neues Jahrbuch für Geologie und Paläontologie, Monatshefte 11, 511-518.

Eisenack, A. \& Kjellström, G. 1972: Katalog der Fossilen Dinoflagellaten, Hystrichosphären und Verwandten Mikrofossilien. Band II. Dinoflagellaten, 1132 p. Stuttgart: E. Schweizerbart'sche Verlagsbuchhandlung.

Eisenack, A. \& Kjellström, G. 1975: Katalog der Fossilen Dinoflagellaten, Hystrichosphären und Verwandten Mikrofossilien. Band II. Dinoflagellaten. 1. Ergänzungslieferung, 518 pp. Stuttgart: E. Schweizerbart'sche Verlagsbuchhandlung.

Elsik, W.C. 1977: Paralecaniella indentata (Defl. \& Cooks. 1955) Cookson and Eisenack 1970 and allied dinocysts. Palynology 1, 95-102.

Evitt, W.R., Clarke, R.F.A. \& Verdier, J.-P. 1967: Dinoflagellate studies III. Dinogymnium acuminatum nov. gen. nov.sp. (Maastrichtian) and other fossils formerly referable to Gymnodinium Stein. Stanford University Publications, Geological Sciences 10(4), 1-27.

Evitt, W.R., Damassa, S.P. \& Albert, N.R. 1998: A tiger by the tail: the exophragm of the Cretaceous-Paleocene dinoflagellate $\mathrm{Pa}$ laeoperidinium and its implications. Palynology 22, 1-55.

Farr, E.R. \& Zijlstra, G. 1996: Index Nominum Genericorum (ING) A compilation of generic names published for organisms covered by the ICN: International Code of Nomenclature for Algae, Fungi, and Plants. (Plantarum). Smithsonian National Museum of Natural History. <http://botany.si.edu/ing/>. Index accessed September 2015.

Fauconnier, D. \& Masure, E. (coordinators) 2004: Les dinoflagellés fossils. Guide pratique de determination. Les genres à processus et à archéopyle apical, 602 pp. BRGM Éditions, Collection scientifique.

Fensome, R.A. 1983: Miospores from the Jurassic-Cretaceous boundary beds, Aklavik Range, Northwest Territories, Canada, 762 pp (2 parts). Unpublished PhD thesis, University of Saskatchewan, Saskatoon, Saskatchewan, Canada.

Fensome, R.A. \& Williams, G.L. 2004: The Lentin and Williams Index of fossil dinoflagellates. American Association of Stratigraphic Palynologists, Contributions Series 42, 909 pp.

Fensome, R.A. \& Williams, G.L. 2005: Scotian margin PalyAtlas, Version 1. Geological Survey of Canada Open File Report 46 77, (distributed as CD only).

Fensome, R.A., Williams, G.L., Barss, M.S., Freeman, J.M. \& Hill, J.M. 1990: Acritarchs and fossil prasinophytes: an index to genera, species and infraspecific taxa. American Association of Stratigraphic Palynologists, Contributions Series 25, 771 pp.

Fensome, R.A., Taylor, F.J.R., Norris, G., Sarjeant, W.A.S., Wharton, D.I. \& Williams, G.L. 1993: A classification of fossil and living dinoflagellates. Micropaleontology Press Special Paper 7, $351 \mathrm{pp}$.

Fensome, R.A., Guerstein, G.R. \& Williams, G.L. 2007: New insights on the Paleogene Dinoflagellate cyst genera Enneadocysta and Licracysta gen. nov. based on material from offshore eastern Canada and southern Argentina. Micropalaeontology 52(5), 385-410.
Fensome, R.A., Crux, J.A., Gard, I.G., MacRae, R.A., Williams, G.L., Thomas, F.C., Fiorini, F. \& Wach, G. 2008: The last 100 million years on the Scotian Margin, offshore eastern Canada: an event - stratigraphic scheme emphasizing biostratigraphic data. Atlantic Geology 44, 93-126.

Fensome, R.A., Williams, G.L. \& MacRae, R.A. 2009: Late Cretaceous and Cenozoic fossil dinoflagellates and other palynomorphs from the Scotian Margin, offshore eastern Canada. Journal of Systematic Palaeontology 7(1), 1-79.

Frantz, U. 1960: Über das Vorkommen von Olacaceen - Pollenkörnern in der Braunkohle von Lohsa/ Niederlausitz. Deutsche Akademie der Wissenschaften zu Berlin, Monatsberichte 2(9), 558-564.

Funkhouser, J.W. 1961. Pollen of the genus Aquilapollenites. Micropaleontology 7(2), 193-198.

Gerlach, E. 1961: Mikrofossilien aus dem Oligozän und Miozän Nordwestdeutschlands, unter besonderer Berücksichtigung der Hystrichosphaeren und Dinoflagellaten. Neues Jahrbuch für Geologie und Paläontologie Abhandlungen 112(2), 143-228.

Gocht, H. 1955: Rhombodinium und Dracodinium, zwei neue Dinoflagellaten-Gattungen aus dem norddeutschen Tertiär. Neues Jahrbuch für Geologie und Paläontologie, Monatshefte 2, 84-92.

Gocht, H. 1957: Mikroplankton aus dem nordwestdeutschen Neokom (Teil I). Paläontologische Zeitschrift 31, 163-185.

Gocht, H. 1960: Die Gattung Chiropteridium n. gen. (Hystrichosphaeridea) im deutschen Oligozän. Paläontologische Zeitschrift 34, 221-232.

Gocht, H. 1968: Zur Morphologie und Ontogenie von Thalassiphora (Dinoflagellata). Palaeontographica Abteilung A 129, 149-156.

Gocht, H. 1969: Formengemeinschaften alttertiären Mikroplanktons aus Bohrproben des Erdölfeldes Meckelfeld bei Hamburg. Palaeontographica Abteilung B 126, 1-100.

Gocht, H. 1970: Dinoflagellaten-Zysten aus einem Geschiebefeuerstein und ihr Erhaltungszustand. Neues Jahrbuch für Geologie und Paläontologie, Monatshefte 3, 129-140.

Gocht, H. 1976: Hystrichosphaeropsis quasicribrata (O. Wetzel), ein Dinoflagellat aus dem Maastricht Nordeuropas. Mit einem nomenklatorischen Nachtrag zur Gattung Lithodinia Eis. The dinoflagellate Hystrichosphaeropsis quasicribrata (O. Wetzel) from the north European Maestrichtian (with additional remarks to the genus Lithodinia Eis.). Neues Jahrbuch für Geologie und Paläontologie, Monatshefte 6, 321-336.

Gocht, H. \& Netzel, H. 1976: Reliefstrukturen des KreideDinoflagellaten Palaeoperidinium pyrophorum (Ehr.) im Vergleich mit Panzer-Merkmalen rezenter Peridinium-Arten. Relief structures of the Cretaceous dinoflagellate Palaeoperidinium $p y$ rophorum (Ehr.) compared with thecal structures of Recent Peridinium species. Neues Jahrbuch für Geologie und Paläontologie Abhandlungen 152(3), 380-413.

Górka, H. 1963: Coccolithophoridés, dinoflagellés, hystrichosphaeridés et microfossiles incertae sedis du Crétacé supérieur de Pologne. Acta Palaeontologica Polonica 8(1), 1-83.

Gradstein, F.M., Ogg, J.G., Schmitz, M.D. \& Ogg, G.M 2012: The geologic time scale 2012. 1176 pp. Elsevier.

Gregersen, U., Hopper, J.R. \& Knutz, P.C. 2013: Basin seismic 
stratigraphy and aspects of prospectivity in NE Baffin Bay, Northwest Greenland. Marine and Petroleum Geology 46, 1-18.

Gregory, W.A. \& Hart, G.F. 1995: Distribution of dinoflagellates in a subsurface marine Wilcox (Paleocene-Eocene) section in Southwest Louisiana. Palynology 19(1), 45-75.

Grigorovich, A.S. 1971: Mikrofitoplankton melovykh i paleogenovykh otlozhenii severnogo sklona Ukrainskikh Karpat. Moskovskoe Obshchestvo Ispytatelei Prirody, Biulleten, Otdel Geologicheskii 46(2), 83-98.

Habib, D. 1994: Biostratigraphic evidence of the KT boundary in the eastern Gulf coastal plain north of the Chicxulub Crater. Snowbird Conference: New Developments Regarding the KT Event and Other Catastrophes in Earth History. Lunar and Planetary Institute of Houston, Texas, February 12-19, 1994. Handout, poster presentation, $7 \mathrm{pp}$.

Hansen, H.J., Gwozdz, R., Hansen, J.M.., Bromley, R. \& Rasmussen, K.L. 1986: The diachronous C/T plankton extinction in the Danish Basin. In: O. Walliser (ed.) Global Bioevents Lecture Notes on Earth Sciences (Springer, Berlin) 8, 381-384.

Harding, I.C. 1990: A dinocyst calibration of the European Boreal Barremian. Palaeontographica Abteilung B 218, 1-76.

Harker, S.D. 1979: Archeopyle formation in Palaeohystrichophora infusurioides Deflandre 1935. Neues Jahrbuch für Geologie und Paläontologie, Monatshefte 6, 369-377.

Harker, S.D. \& Sarjeant, W.A.S. 1975: The stratigraphic distribution of organic-walled dinoflagellate cysts in the Cretaceous and Tertiary. Review of Palaeobotany and Palynology 20(4), 217315.

Harker, S.D., Sarjeant, W.A.S. \& Caldwell, W.G.E. 1990: Late Cretaceous (Campanian) organic-walled microplankton from the interior plains of Canada, Wyoming and Texas: biostratigraphy, palaeontology and palaeoenvironmental interpretation. Palaeontographica Abteilung B 219(1-6), 243 pp.

Harland, R. 1973: Dinoflagellate cysts and acritarchs from the Bearpaw Formation (Upper Campanian) of southern Alberta, Canada Palaeontology 16(4), 665-706.

Harland, R. 1977: Dinoflagellate cysts from the Bearpaw Formation (?Upper Campanian to Maastrichtian) of Montana. Palaeontology 20(1), 179-193.

Harland, R. 1979a: Agerasphaera nov. gen., an 'Eisenackia'-like dinoflagellate cyst from the Thanet Sands (Paleocene) of southeast England. Review of Palaeobotany and Palynology 28, 27-35.

Harland, R. 1979b: The Wetzeliella (Apectodinium) homomorphum plexus from the Palaeogene/earliest Eocene of north-west Europe. Fourth International Palynology Conference, Lucknow, 19761977. Proceedings 2, 59-70.

Harris, W.K \& Fensome, R.A. 2000: (1447) Proposal to conserve the name Diphyes Cookson (Dinophyceae) against Diphyes Blume (Orchidaceae). Taxon 49, 281-282.

Harrison, J.C., Mayr, U., McNeil, D.H., Sweet, A.R., McIntyre, D.J., Eberle, J.J., Harington, C.R., Chalmers, J.A., Dam, G. \& Nøhr-Hansen, H. 1999: Correlation of Cenozoic sequences of the Canadian Arctic region and Greenland; implications for the tectonic history of northern North America. Bulletin of Canadian Petroleum Geology 47(3), 223-254.
He Chengquan 1984: Some new genera of Late Cretaceous to Eocene microphytoplankton from western Tarim Basin in southern Xinjiang. Acta Palaeontologica Sinica 23(6), 768-774. (In Chinese and English.)

He Chengquan \& Wang Kede 1990: Eocene dinoflagellates from the southwestern continental shelf basin of the East China Sea. Acta Micropalaeontologica Sinica 7(4), 403-426. (In Chinese with English summary.)

He Chengquan, Gao Ruiqi \& Qiao Xiuyun 1992: New Albian microphytoplankton from the Songliao Basin, northeast China. Acta Micropalaeontologica Sinica 9(2), 183-196.

Head, M.J. 1994: Morphology and paleoenvironmental significance of the Cenozoic dinoflagellate genera Tectatodinium and Habibacysta. Micropaleontology 40(4), 289-321.

Head, M.J. 1996: Chapter 30. Modern dinoflagellate cysts and their biological affinities. In: Jansonius, J. \& McGregor, D.C. (eds): Palynology: Principles and Applications 3, 1197-1248. American Association of Stratigraphic Palynologists Foundation, Dallas, U.S.A.

Head, M.J., Norris, G. \& Mudie, P.J. 1989: 26. New species of dinocysts and a new species of acritarch from the upper Miocene and lowermost Pliocene, ODP Leg 105, Site 646, Labrador Sea. In: Srivastava, S.P. et al. (eds): Ocean Drilling Program Proceedings, Scientific Results 105, 453-466.

Heilmann-Clausen, C. \& Costa, L.I. 1989: Dinoflagellate zonation of the uppermost Paleocene? to Lower Miocene in the Wursterheide Research Well, NW Germany. Geologisches Jahrbuch 111, 431-521.

Helby, R.J., Morgan, R. \& Partridge, A.D. 1987: A palynological zonation of the Australian Mesozoic. In: Jell, P.A. (ed.): Studies in Australian Mesozoic palynology. Memoirs of the Assocation of Australasian Palaeontologists 4, 1-94.

Helenes, J. 1984: Dinoflagellates from Cretaceous to early Tertiary rocks of the Sebastian Vizcaino Basin, Baja California, Mexico. In: Frizzell, V.A. Jr. (ed.): Geology of the Baja California Peninsula, Pacific Section. Society of Economic Paleontologists and Mineralogists 39, 89-106.

Hemer, D.O. \& Nygreen, P.W. 1967: Algae, acritarchs and other microfossils incertae sedis from the Lower Carboniferous of Saudi Arabia. Micropaleontology 13(2), 183-194.

Henriksen, N., Higgins, A.K., Kalsbeek, F. \& Pulvertaft, T.C.R. 2009: Greenland from Archaean to Quaternary. Descriptive text to the 1995 geological map of Greenland 1:2 500 000. Geological Survey of Denmark and Greenland Bulletin 18, 126 pp.

Ioannides, N.S. 1986: Dinoflagellate cysts from Upper Cretaceous - Lower Tertiary sections, Bylot and Devon Islands, Arctic Archipelago. Geological Survey of Canada Bulletin 371, 1-99.

Islam, M.A. 1982: Dinoflagellate age of the boundary between Ieper and Panisel Formations (early Eocene) at Egem, Belgium, and its significance. Neues Jahrbuch für Geologie und Paläontologie, Monatshefte 8, 485-490.

Islam, M.A. 1983a: Dinoflagellate cyst taxonomy and biostratigraphy of the Eocene Bracklesham Group in southern England. Micropaleontology 29, 328-353.

Islam, M.A. 1983b: Dinoflagellate cysts from the Eocene of the 
London and the Hampshire basins, southern England. Palynology 7, 71-92.

Islam, M.A. 1993: Review of the fossil dinoflagellate Cleistosphaeridium. Revista espańola de micropaleontología 25(2), 81-94.

Ivanova, E.A. \& Markova, L.G. 1961: Schizaeaceae. In: Samoilovich, S.R. \& Mtchedlishvili, N.D. (eds): Pollen and spores of western Siberia. Jurassic to Paleocene (Pyltsa i spory zapadnoi Sibiri, YuraPaleotsen. Trudy Vsesoyuznyi Neftyanoi Nauchno-issledovatelskii Geologorazvedochnyi Institut, Leningrad (VNIGRI) 177, 64-112.

Jackson, G.D., Iannelli, T.R., Narbonne, G.M. \& Wallace, P.J. 1978: Upper Proterozoic sedimentary and volcanic rocks of northwestern Baffin Island. Geological Survey of Canada, Paper 78-14, 1-15.

Jain, K.P. \& Garg, R. 1986: Revision and reassessment of a dinoflagellate cyst assemblage from Sangchamalla Formation (Upper Flysch), Malla Johar area, Kumaon Himalaya, India. The Palaeobotanist 35, 61-68.

Jain, K.P. \& Millepied, P. 1973: Cretaceous microplankton from Senegal Basin, NW Africa. 1. Some new genera, species and combinations of dinoflagellates. The Palaeobotanist 20, 22-32.

Jan du Chêne, R.E. \& Châteauneuf, J.-J. 1975: Nouvelles espèces de Wetzeliella et Deflandrea (Pyrrhophyta, Dinophyceae) de l'Eocène des Alpes occidentales. Revue de Micropaléontologie 18, 28-37.

Jan du Chêne, R.E. et al. 1986: Guide pratique pour la détermination de kystes de dinoflagellés fossiles. Le complexe Gonyaulacysta. Bulletin des Centres de recherches exploration-production Elf-Aquitaine, Mémoir 12, 479 pp.

Jansonius, J. 1986: Re-examination of Mesozoic Canadian dinoflagellate cysts published by S.A.J. Pocock (1962, 1972). Palynology 10, 201-223.

Jansonius, J. 1989: The species of Fromea (fossil dinoflagellates). Review of Palaeobotany and Palynology 61, 63-68.

Jansonius, J. \& Hills, L.V. 1976, 1981: Genera file of fossil spores and pollen. Special Publication, Department of Geology, University of Calgary, Canada. 3287 filing cards (supplements issued from 1977).

Jansonius, J. \& Hills, L.V. 1987: Genera file of fossil spores, supplement 9. Department of Geology and Geophysics, University of Calgary, Canada. Filing cards 4361-4575.

Jiabo 1978: On the Paleogene dinoflagellates and acritarchs from the coastal region of Bohai, 190 pp. Nanjing Institute of Geology and Palaeontology, Academia Sinica, Nanjing, China. (In Chinese with English summary.)

Jolley, D.W. 1992: A new species of the dinoflagellate genus Areoligera Lejeune-Carpentier from the Late Palaeocene of the eastern British Isles. Tertiary Research 14(1), 25-32.

Kar, R.K. \& Sah, S.C.D. 1970: Palynological investigation of the Gondwana outcrop from Vemavaram, with remarks on the age of the bed. The Palaeobotanist 18, 103-117.

Kedves, M.J and Király, E. 1970: Problems of Cretaceous Palaeogene palaeophytogeographical regions based on palynological results. II. Acta Biologica Szeged 16, 63-72.

Khanna, A.K. \& Singh, H.P. 1980: Subathua - a new dinoflagellate genus and its palaeoecological significance in the Subathu Formation, Simla Hills. The Palaeobotanist 26(3), 307-313.

Khlonova, A.F. 1961: Spores and pollen of the upper half of the Upper Cretaceous from the eastern part of the West-Siberian lowland. Trudy Inst. Geol. \& Geophys., Acad. Sci. U.S.S.R. (Siberian Branch) 7, 138 pp. (In Russian.)

Khlonova, A.F. 1962: Some morphological types of spores and pollen grains from Upper Cretaceous of eastern part of West Siberian lowland. Pollen et Spores 4(2), 297-309.

Khowaja-Ateequzzaman, Garg, R. \& Jain, K.P. 1991: Some observations on dinoflagellate cyst genus Alterbidinium Lentin and Williams 1985. The Palaeobotanist 39(1), 37-45.

Kirsch, K.-H. 1991: Dinoflagellatenzysten aus der Oberkreide des Helvetikums und Nordultrahelvetikums von Oberbayern. Münchner Geowissenschaftliche Abhandlungen, Reihe A, Geologie und Palaontologie 22, 1-306.

Kjellström, G. 1973: Maastrichtian microplankton from the Höllviken Borehole No.1 in Scania, southern Sweden. Sveriges Geologiska Undersökning, Serie C, no.688, 67 (8), 1-59.

Klement, K.W. 1960: Dinoflagellaten und Hystrichosphaerideen aus dem unteren und mittleren Malm Südwestdeutschlands. Palaeontographica Abteilung A 114(1-4), 1-104.

Klumpp, B. 1953: Beitrag zur Kenntnis der Mikrofossilien des mittleren und oberen Eozän. Palaeontographica Abteilung A 103, 377-406.

Kokinos, J.P. \& Anderson, D.M. 1995: Morphological development of resting cysts in cultures of the marine dinoflagellate Lingulodinium polyedrum (= L. machaerophorum). Palynology 19, 143-166.

Krutzsch, W. 1959: Mikropaläontologische (sporenpaläontologische) Untersuchungen in der Braunkohle des Geiseltales. Geologie 8(21-22), 1-245.

Krutzsch, W. 1966: Zur Kenntnis der präquartären periporaten Pollenformen aus dem deutschen Tertiär. On the recognition of Pre-Quaternary periporate pollenforms. Zeitschrift für das Gesamtgebiet der Geologischen Wissenschaften, Geologie 15(55), 16-71.

Krutzsch, W. 1970: Atlas der mittel- und jungtertiären dispersen Sporen- und Pollen- sowie der Mikroplanktonformen des nördlichen Mitteleuropas. Lieferung VII: monoporate, monocolpate, longicolpate, dicolpate und ephedrioide (polyplicate) Pollenformen. 175 pp. Jena, Germany: VEB Gustav Fischer Verlag.

Lamarck, J.B. et al. 1783: Encyclopédie mêthodique botanique. 1(1), 343 pp. Paris: Pancouche, Plomteux.

Lange, D. 1969: Mikroplankton aus dem Fischton von StevnsKlint auf Seeland. Beiträge zur Meereskunde 24-25, 110-121.

Larsen, L.M., Pedersen, A.K., Tegner, C., Duncan, R.A., Hald, N. \& Larsen, J.G. 2016: Age of Tertiary volcanic rocks on the West Greenland continental margin: volcanic evolution and event correlation to other parts of the North Atlantic Igneous Province. Geological Magazine 153(03), 487-511, http://dx.doi.org/10.1017/S0016756815000515

Lejeune-Carpentier, M. 1938: L'étude microscopique des silex. Areoligera: nouveau genre d'hystrichosphaeridée. (Sixième note) Annales de la Société géologique de Belgique 62, B163-B174. 
Lejeune-Carpentier, M. 1942: L'étude microscopique des silex. Péridiniens nouveaux ou peu connus. (Dixième note) Annales de la Société géologique de Belgique 65, B181-B192.

Lejeune-Carpentier, M. \& Sarjeant, W.A.S. 1981: Restudy of some larger dinoflagellate cysts and an acritarch from the Upper Cretaceous of Belgium and Germany. Annales de la Société géologique de Belgique 104, 1-39.

Lentin, J.K. \& Manum, S.B. 1986: A new peridinioid dinoflagellate from Campanian sediments recovered from DSDP Leg 22, Site 217, Indian Ocean. Palynology 10, 111-116.

Lentin, J.K. \& Vozzhennikova, T.F. 1989: The fossil dinoflagellate cysts Kisselovia emend. and Charlesdowniea gen. nov. Review of Palaeobotany and Palynology 58, 215-229.

Lentin, J.K. \& Vozzhennikova, T.F. 1990: Fossil dinoflagellates from the Jurassic, Cretaceous and Paleogene deposits of the USSR - a re-study. American Association of Stratigraphic Palynologists, Contributions Series 23, 221 pp.

Lentin, J.K. \& Williams, G.L. 1973: Fossil dinoflagellates: index to genera and species. Geological Survey of Canada, Paper 73-42, $176 \mathrm{pp}$.

Lentin, J.K. \& Williams, G.L. 1975: Fossil dinoflagellates: index to genera and species. Supplement 1. Canadian Journal of Botany 53, 2147-2157.

Lentin, J.K. \& Williams, G.L. 1976: A monograph of fossil peridinioid dinoflagellate cysts. Bedford Institute of Oceanography, Report Series BI-R-75-16, 237 pp.

Lentin, J.K. \& Williams, G.L. 1977a: Fossil dinoflagellates: index to genera and species, 1977 edition. Bedford Institute of Oceanography, Report Series BI-R-77-8, 209 pp.

Lentin, J.K. \& Williams, G.L. 1977b: Fossil dinoflagellate genus Isabelidinium nom. nov. Palynology 1, 167-168.

Lentin, J.K. \& Williams, G.L. 1980: Dinoflagellate provincialism with emphasis on Campanian peridiniaceans. American Association of Stratigraphic Palynologists, Contributions Series 7, 1-47.

Lentin, J.K. \& Williams, G.L. 1981: Fossil dinoflagellates: index to genera and species, 1981 edition. Bedford Institute of Oceanography, Report Series BI-R-81-12, 345 pp.

Lentin, J.K. \& Williams, G.L. 1985: Fossil dinoflagellates: index to genera and species, 1985 edition. Canadian Technical Report of Hydrography and Ocean Sciences 60, 451 pp.

Lentin, J.K. \& Williams, G.L. 1987: Status of the fossil dinoflagellate genera Ceratiopsis Vozzhennikova 1963 and Cerodinium Vozzhennikova 1963 emend. Palynology 11, 113-116.

Levet-Carette, J. 1964: Microflore infraliassique du Boulonnais (carrière Napoléon). Annales Société géologique du Nord 84, 265-287.

Liengjarern, M., Costa, L. \& Downie, C. 1980: Dinoflagellate cysts from the Upper Eocene-Lower Oligocene of the Isle of Wight. Palaeontology 23, 475-499.

Lindgren, S. 1980: Algal microfossils of the form genus Tetraporina from Upper Cretaceous clays, southern Sweden. Review of Palaeobotany and Palynology 30, 333-359.

Lindgren, S. 1984: A new taxon of Leiosphaeridia (algae) from the Upper Cretaceous of southern Sweden. Acta Universitatis Stockholmiensis, Stockholm Contributions in Geology, 39(5), 139-144.
Loeblich, A.R., Jr. \& Loeblich, A.R. III. 1968: Index to the genera, subgenera, and sections of the Pyrrhophyta, II. Journal of Paleontology 42, 210-213.

McIntyre, D.J. 1975: Morphologic changes in Deflandrea from a Campanian section, District of Mackenzie, N.W.T., Canada. Geoscience and Man 11, 61-76.

MacLean, B., Williams, G.L. \& Zhang, S. 2014: New insights into the stratigraphy and petroleum potential of the Baffin Shelfs Cretaceous rocks. Bulletin of Canadian Petroleum Geology 62, 289-310.

McNeill, J. et al. 2012: International Code of Nomenclature for algae, fungi, and plants (Melbourne Code). Regnum Vegetabile 154. Koeltz Scientific Books, http://www.iapt-taxon.org/nomen/main.php

McWhae, J.R.H. 1981: Structure and spreading history of the northwestern Atlantic region from the Scotian Shelf to Baffin Bay. In: Kerr, J.W. \& Fergusson, A.J. (eds): Geology of the North Atlantic borderlands. Canadian Society of Petroleum Geologists Memoir 7, 299-332.

Maier, D. 1959: Planktonuntersuchungen in tertiären und quartären marinen Sedimenten. Ein Beitrag zur Systematik, Stratigraphie und Ökologie der Coccolithophorideen, Dinoflagellaten und Hystrichosphaerideen vom Oligozän bis zum Pleistozän. Neues Jahrbuch für Geologie und Paläontologie Abhandlungen 107(3), 278-340.

Mantell, G.A. 1850: A pictorial atlas of fossil remains consisting of coloured illustrations selected from Parkinson's Organic Remains of a Former World, and Artis's Antediluvian Phytology. xii+207 pp. London: Henry G. Bohn.

Manum, S.B. 1960: Some dinoflagellates and hystrichosphaerids from the Lower Tertiary of Spitsbergen. Nytt Magasin for Botanikk 8, 17-26.

Manum, S.B. 1979: Two new Tertiary dinocyst genera from the Norwegian Sea: Lophocysta and Evittosphaerula. Review of Palaeobotany and Palynology 28, 237-248.

Manum, S.B. \& Cookson, I.C. 1964: Cretaceous microplankton in a sample from Graham Island, Arctic Canada, collected during the second Fram expedition (1898-1902). With notes on microplankton from the Hassel Formation, Ellef Ringnes Island. Skrifter, Det Norske Videnskaps-Akademi i Oslo. I. Matematisk-Naturvidenskapelig klasse. Ny Serie 17, 1-36.

Mao Shaozhi \& Norris, G. 1988: Late Cretaceous - early Tertiary dinoflagellates and acritarchs from the Kashi area, Tarim Basin, Xinjiang Province, China. Royal Ontario Museum. Life Sciences Contributions 150, 1-93.

Mao Shaozhi, Wan Chunbiao \& Qiao Xiayun 1999: Cretaceous nonmarine dinoflagellates from northeast China. Grana 38(23), 144-161.

Marheinecke, U. 1992: Monographie der Dinozysten, Acritarcha und Chlorophyta des Maastrichtium von Hemmoor (Niedersachsen). Palaeontographica Abteilung B 227(1-6), 1-173.

Marshall, N.G. 1989: An unusual assemblage of algal cysts from the Late Cretaceous of the Gippsland Basin, southeastern Australia. Palynology 13, 21-56.

Masure, E. 1991: Morphology of the dinoflagellate genus Atopo- 
dinium Drugg emend., senior synonym of Maghrebinia Below and Bejuia Stover and Williams. Palynology 15, 63-80.

Matsuoka, K. 1983: Late Cenozoic dinoflagellates and acritarchs in the Niigata district, central Japan. Palaeontographica Abteilung B 187(1-3), 89-154.

Meyen, F.I.F. 1828: Beobactungen über einige niedere Algenformen. Nova Acta Physico-Medica Academiae Caesareae Leopoldino-Carolinae Naturae Curiosorum 14, 768-778.

Meyer, B.L. 1956: Mikrofloristische Untersuchungen an jungtertiären Braunkohlen im östlichen Bayern. Geologica Bavarica, 25, 100-128.

Miall, A.D. 1986: The Eureka Sound Group (Upper CretaceousOligocene), Canadian Arctic Islands. Bulletin of Canadian Petroleum Geology 34, 240-270.

Michoux, D. 1985: Palynostratigraphie de l'Éocène de Montforten-Chalosse (Landes, France). Revue de Micropaléontologie 28, 138-153.

Michoux, D. 1988: Dinoflagellate cysts of the Wetzeliella-complex from Eocene sediments of the Aquitaine Basin, southwestern France. Palynology 12, 11-41.

Millioud, M.E. 1969: Dinoflagellates and acritarchs from some western European Lower Cretaceous type localities. In: Brönnimann, P. \& Renz, H.H. (eds): 1st International Conference on Planktonic Microfossils, Geneva 1967. Proceedings 2, 420-434.

Morgenroth, P. 1966a: Mikrofossilien und Konkretionen des nordwesteuropäischen Untereozäns. Palaeontographica Abteilung B 119(1-3), 1-53.

Morgenroth, P. 1966b: Neue in organischer Substanz erhaltene Mikrofossilien des Oligozäns. Neues Jahrbuch für Geologie und Paläontologie Abhandlungen 127, 1-12.

Morgenroth, P. 1968: Zur Kenntnis der Dinoflagellaten und Hystrichosphaeridien des Danien. Geologisches Jahrbuch 86, 533578.

Mudie, P.J. 1987: Palynology and dinoflagellate biostratigraphy of DSDP Leg 94, Sites 607 and 611, North Atlantic Ocean. In: Ruddiman, W.F. et al. (eds): Deep Sea Drilling Project, Washington, Initial Reports 94, 785-812.

Nagy, E. 1965: The microplankton occurring in the Neogene of the Mecsek Mountains. Acta Botanica, Académiae Scientiarum Hungaricae 11, 197-216.

Nakoman, E. 1965: Description d'un nouveau genre de Forme. Annales de la Société géologique du Nord 85, 155-158.

Naumova, S.N. 1939: Spores and pollen of the coals of the U.S.S.R. Report of the XVII International Geological Congress 1937, Moscow 1, 353-364.

Naumova, S.N. 1950: Spory nizhnego silura. Trudy Konferentsii po Sporovo-Pyltsevomu Analizu, 1948 Goda, 165-190. Moscow: Geograficheskii Facultet, Izdatelstvo Moskovskogo Universiteta.

Neale, J.W. \& Sarjeant, W.A.S. 1962: Microplankton from the Speeton Clay of Yorkshire. Geological Magazine 99, 439-458.

Nichols, D.J. \& Ott, H.L. 1978: Biostratigraphy and evolution of the Momipites-Caryapollenites lineage in the early Tertiary in the Wind River Basin, Wyoming. Palynology 2, 94-112.

Nichols, D.J. \& Sweet, A.R. 1993: Biostratigraphy of Upper Cre- taceous non-marine palynofloras in a north-south transect of the Western Interior Basin. In: Caldwell, W.G.E. \& Kauffman, E.G. (eds): Evolution of the Western Interior Basin. Geological Society of Canada Special Paper 39, 539-584.

Nilsson, T. 1958: Über das Vorkommen eines mesozoischen Sapropelgesteins in Schonen. Lunds Universitets Årsskrift, $\mathrm{Ny}$ Följd, Avd. 2, 54(10), 1-112.

Nøhr-Hansen, H. 1993: Dinoflagellate cyst stratigraphy of the Barremian to Albian, Lower Cretaceous, North-East Greenland. Grønlands Geologiske Undersøgelse Bulletin 166, 171 pp.

Nøhr-Hansen, H. 1996: Upper Cretaceous dinoflagellate cyst stratigraphy, onshore West Greenland. Grønlands Geologiske Undersøgelse Bulletin 170, 104 pp.

Nøhr-Hansen, H. 2003: Dinoflagellate cyst stratigraphy of the Palaeogene strata from the Hellefisk-1, Ikermiut-1, Kangâmiut-1, Nukk-1, Nukik-2 and Qulleq-1 wells, offshore West Greenland. Marine and Petroleum Geology 20, 987-1016.

Nøhr-Hansen, H. 2012: Palynostratigraphy of the Cretaceous lower Palaeogene sedimentary succession in the Kangerlussuaq Basin, southern East Greenland. Review of Palaeobotany and Palynology 178, 59-90.

Nøhr-Hansen, H. \& Heilmann-Clausen, C. 2001: Cerodinium kangiliense and Senegalinium iterlaaense n. sp. - two new stratigraphically important Paleocene species from West Greenland and Denmark. Neues Jahrbuch für Geologie und Paläontologie Abhandlungen 219(1-2), 153-170.

Nøhr-Hansen, H., Sheldon, E. \& Dam, G. 2002: A new biostratigraphic scheme for the Paleocene onshore West Greenland and its implications for the timing of the pre-volcanic evolution. In: Jolley, D.W. \& Bell, B.R. (eds): The North Atlantic igneous province: stratigraphy, tectonic, volcanic and magmatic processes. Geological Society Special Publication (London) 197, 111-156.

Nøhr-Hansen, H., Nielsen, L.H., Sheldon, E., Hovikoski, J. \& Alsen, P. 2011: Palaeogene deposits on North-East Greenland. Geological Survey of Denmark and Greenland Bulletin 23, 6164.

Nøhr-Hansen, H., Williams, G.L. \& Fensome, R.A. 2016: Biostratigraphic correlation of the western and eastern margins of the Labrador-Baffin Seaway and implications for the regional geology. Geological Survey of Denmark and Greenland Bulletin 37 (in press).

Norris, G. 1969: Miospores from the Purbeck Beds and marine Upper Jurassic of southern England. Paleontology 12, 574-620.

Norvick, M.S. 1973: The microplankton genus Disphaeria Cookson and Eisenack emend. Bureau of Mineral Resources. Geology and Geophysics Bulletin 140, 45-46.

Oakey, G.N. \& Chalmers, J.A. 2012: A new model for the Paleogene motion of Greenland relative to North America: plate reconstructions of the Davis Strait and Nares Strait regions between Canada and Greenland. Journal of Geophysical Research 117, 28 pp., http://dx.doi/org/ 10.1029/2011JB008942.

Pacltová, B. 1961: On some plant microfossils from fresh-water sediments of the upper Cretaceous (Senonian) in the south-Bohemian Basins. Part I. (Summary of the Czech text). Sborník Ústredního Ústavu Geologického, Oddíl Paleontologický 26, 38-55. 
Palynodata Inc. \& White, J.M. 2008: Palynodata Datafile: 2006 version, with Introduction by J.M. White. Geological Survey of Canada Open File 5793, 1 CD-ROM.

Pant, D.D. \& Mehra, B. 1963: On the occurrence of glossopterid spores in the Bacchus Marsh tillite, Victoria, Australia. Grana Palynologica 4, 111-120.

Pascher, A. 1914: Über Flagellaten und Algen. Deutsche Botanische Gesellschaft Berichte 32, 136-160.

Pastiels, A. 1948: Contribution à l'étude des microfossiles de l'Éocène belge. Mémoires du Musée royal d'histoire naturelle de Belgique 109, 1-77.

Pearce, M. 2010: New organic-walled dinoflagellate cysts from the Cenomanian to Maastrichtian of the Trunch borehole, UK. Journal of Micropalaeontology 29, 51-72.

Pedersen, A.K., Larsen, L.M., Riisager, P. \& Dueholm, K.S. 2002: Rates of volcanic deposition, facies changes and movements in a dynamic basin: the Nuussuaq Basin, West Greenland, around the C27n-C26r transition. In: Jolley, D.W. \& Bell, B.R. (eds): The North Atlantic Igneous Province: Stratigraphy, Tectonic, Volcanic and Magmatic Processes. Geological Society Special Publications (London) 197, 157-181.

Pedersen, G.K. \& Nøhr-Hansen, H. 2014: Sedimentary successions and palynoevent stratigraphy from the non-marine Lower Cretaceous to the marine Upper Cretaceous of the Nuussuaq Basin, West Greenland. Bulletin of Canadian Petroleum Geology 62(4), 216-244.

Penny, J.S. 1969: Late Cretaceous and Tertiary palynology. In: Tschudy, R.H. \& Scott, R.A. (eds): Aspects of Palynology, 331376. New York: Wiley-Interscience.

Pflug, H.D. 1953: Zur Entstehung und Entwicklung des angiospermiden Pollens in der Erdgeschichte. Palaeontographica Abteilung B 95(4-6), 60-171.

Piasecki, S. 2003: Neogene dinoflagellate cysts from the Davis Strait, offshore West Greenland. Marine and Petroleum Geology 20, 1075-1088.

Piasecki, S., Larsen, L.M., Pedersen, A.K. \& Pedersen, G.K. 1992: Palynostratigraphy of the Lower Tertiary volcanics and marine clastic sediments in the southern part of the west Greenland Basin: implications for the timing and duration of the volcanism. Grønlands Geologiske Undersøgelse, Rapport 154, 13-31.

Pierce, R.L. 1961: Lower Upper Cretaceous plant micro-fossils from Minnesota. Minnesota Geological Survey Bulletin 42, 86 pp.

Pocock, S.A.J. 1962: Microfloral analysis and age determination of strata at the Jurassic-Cretaceous boundary in the western Canada plains. Palaeontographica Abteilung B 111, 1-95.

Pocock, S.A.J. 1964: Pollen and spores of Chlamydospermidae and Schizaeaceae from Upper Manville strata of the Saskatoon area of Saskatchewan. Grana Palynologica 5(2), 129-209.

Pöthe de Baldis, E.D. 1966: Microplancton del Terciario de Tierra del Fuego. Ameghiniana, 4(7), 219-228.

Potonié, R. 1931: Pollenformen aus tertiären Braunkohlen. III. Jahrbuch Preussische Geologischen Landesanstalt 52, 1-7.

Potonié, R. 1934: Zur Mikrobotanik des eocänen Humodils des Geiseltals. Arbeiten aus dem Institut für Paläobotanik und Petrographie der Brennsteine 4, 25-125.
Potonié, R. 1951: Revision stratigraphisch wichtiger Sporomorphen des mitteleuropäischen Tertiärs. Palaeontographica Abteilung B 91, 131-151.

Potonié, R. 1956: Synopsis der Gattungen der Sporae dispersae. Teil I. Sporites. Beihefte zum Geologisches Jahrbuch 23, 1-103.

Potonié, R. 1958: Synopsis der Gattungen der Sporae dispersae. Teil II. Nachträge Sporites, Saccites, Aletes, Praecolpates, Polyplicates, Monocolpates. Beihefte zum Geologisches Jahrbuch, 31, 1-114.

Potonié, R. 1960: Synopsis der Gattungen der Sporae Dispersae. Teil III. Beihefte zum Geologischen Jahrbuch 39, 1-189.

Potonié, R. 1966: Synopsis der Gattungen der Sporae dispersae. Teil IV. Nachträge zu allen Gruppen (Turmae). Beihefte zum Geologisches Jahrbuch, 72, 1-244.

Potonié, R. \& Gelletich, J. 1933: Über Pteridophyten-Sporen einer eozänen Braunkohle aus Dorog in Ungarn. Sitzungsberichte der Gesellschaft Naturforschender Freunde zu Berlin Jahrgang 1932(8-10) 517-528.

Potonié, R. \& Venitz, H. 1934: Zur Mikrobotanik des miozänen Humodils der niederrheinischen Bucht. In: Zur Mikrobotanik der Kohlen und ihrer Verwandten. Arbeiten aus dem Institut fur Palaobotanik und Petrographie der Brennsteine. Preussischen Geologischen Landesanstalt 5, 8-54.

Potonié, R., Thomson, P. \& Thiergart, F. 1950: Zur Nomenklatur und Klassifikation der Neogenen Sporomorphae (Pollen und Sporen). Geologisches Jahrbuch 65, 35-70.

Qiao Xiuyun, He Chengquan \& Gao Ruiqi 1992: Early Cretaceous freshwater dinoflagellates from Songliao Basin, NE China. Acta Palaeontologica Sinica 31(1), 30-38. (In Chinese with English summary.)

Quattrocchio, M.E. \& Sarjeant, W.A.S. 2003: Dinoflagellates from the Chorrillo Chico Formation (Paleocene) of southern Chile. Ameghiniana 40(2), 129-153.

Raatz, G.V. 1937: Mikrobotanisch-stratigraphische Untersuchung der Braunkohle des Muskauer Bogens. Abhandlungen der preussischen Geologischen Landesanstalt, Neue Folge 183, 3-48.

Radforth, N.W. \& Rouse, G.E. 1954: The classification of recently discovered Cretaceous plant microfossils of potential importance to the stratigraphy of western Canadian coals. Canadian Journal of Botany 32, 187-201.

Radmacher, W., Tyszka, J. \& Mangerud, G. 2014: Distribution and biostratigraphical significance of Heterosphaeridium bellii sp. nov. and other Late Cretaceous dinoflagellate cysts from the southwestern Barents Sea. Review of Palaeobotany and Palynology 201, 29-40.

Regali, M.S.P., Uesugui, N. \& Santos, A.S. 1974: Palinologia dos sedimentos meso-cenozoicos do Brasil (II). Boletim Técnico da Petrobras 17(4), 263-301.

Riding, J.B. 1994: A taxonomic study of the Mesozoic dinoflagellate cysts Phallocysta elongata (Beju 1971) comb. nov., emend. nov. and Wallodinium cylindricum (Habib 1970) Duxbury 1983 emend. nov. Palynology 18, 11-22.

Riding, J.B. \& Fensome, R.A. 2003: A review of Scriniodinium Klement 1957. Endoscrinium (Klement 1960) Vozzhennikova 1967 and related dinoflagellate cyst taxa. Palynology 26, 5-33. 
Robaszynski, F., Bless, M.J.M., Felder, P.J., Foucher, J.-C., Legoux, O., Manivit, H., Meesen, J.P.M.T. \& van der Tuuk, L.A. 1985: The Campanian-Maastrichtian boundary in the chalky facies close to the type-Maastrichtian area. Bulletin des Centres de recherches exploration-production Elf-Aquitaine, 9(1), 1-113.

Rolle, F. 1985: Late Cretaceous-Tertiary sediments offshore central West Greenland: lithostratigraphy, sedimentary evolution, and petroleum potential. Canadian Journal of Earth Sciences 22, 1001-1019.

Rossignol, M. 1962: Analyse pollinique de sédiments marins quaternaires en Israël. II. Sédiments pleistocènes. Pollen et Spores 4(1), 121-148.

Rouse, G.E. 1957: The application of a new nomenclatural approach to Upper Cretaceous plant microfossils from western Canada. Canadian Journal of Botany 35, 349-375.

Rouse, G.E. 1962: Plant microfossils from the Burrard Formation of western British Columbia. Micropaleontology 8(2), 187-218.

Rozen, B. 1965: Contribution à l'étude des hystrichosphères et dinoflagellés du Bartonien belge. Bulletin de la Société belge de géologie, de paléontologie et d'hydrologie 73, 287-318.

Sah, S.C.D., Kar, R.K. \& Singh, R.Y. 1970: Fossil microplankton from the Langpar Formation of Therriaghat, south Shillong Plateau, Assam, India. The Palaeobotanist 18, 143-150.

Samoilovitch, S.R. \& Mtchedlishvili, N.D. (eds) 1961: Pyltsa i spory zapadnoi Sibiri, yura-paleotsen. Vsesoyuznyi Neftyanoi Nauchno-Issledovatelskii Geologorazvedochnyi Institut, Lenin$\operatorname{grad}(\mathrm{VNIGRI})$, Trudy 177, $352 \mathrm{pp}$.

Sarjeant, W.A.S. 1960: New hystrichospheres from the Upper Jurassic of Dorset. Geological Magazine 97(2), 137-144.

Sarjeant, W.A.S. 1962: Microplankton from the Ampthill Clay of Melton, south Yorkshire. Palaeontology 5(3), 478-497.

Sarjeant, W.A.S. 1964: Taxonomic notes on hystrichospheres and acritarchs. Journal of Paleontology 38(1), 173-177.

Sarjeant, W.A.S. 1966a: Further dinoflagellate cysts from the Speeton Clay. In: Davey, R.J. et al. (eds): Studies on Mesozoic and Cainozoic dinoflagellate cysts. Bulletin of the British Museum (Natural History). Geology. Supplement 3, 199-214.

Sarjeant, W.A.S. 1966b: Dinoflagellate cysts with Gonyaulax-type tabulation. In: Davey, R.J. et al. (eds): Studies on Mesozoic and Cainozoic dinoflagellate cysts. Bulletin of the British Museum (Natural History). Geology. Supplement 3, 107-156.

Sarjeant, W.A.S. 1967: The genus Palaeoperidinium Deflandre (Dinophyceae). Grana Palynologica 7, 243-258.

Sarjeant, W.A.S. 1968: Microplankton from the Upper Callovian and Lower Oxfordian of Normandy. Revue de micropaléontologie 10(4), 221-242.

Sarjeant, W.A.S. 1969: Taxonomic changes. In: Davey, R.J. et al. (eds): Appendix to Studies on Mesozoic and Cainozoic Dinoflagellate Cysts. Bulletin of the British Museum (Natural History). Geology. Appendix to Supplement 3, 7-15.

Sarjeant, W.A.S. 1970: The genus Spiniferites Mantell 1850 (Dinophyceae). Grana 10, 74-78.

Sarjeant, W.A.S. 1981: A restudy of some dinoflagellate cyst holotypes in the University of Kiel Collections. II. The Eocene holotypes of Barbara Klumpp (1953); with a revision of the genus
Cordosphaeridium Eisenack 1963. Meyniana 33, 97-132.

Sarjeant, W.A.S. 1982: The dinoflagellate cysts of the Gonyaulacysta group: a morphological and taxonomic restudy. American Association of Stratigraphic Palynologists, Contributions Series $\mathbf{9}$, $1-81$.

Sarjeant, W.A.S. 1983: A restudy of some dinoflagellate cyst holotypes in the University of Kiel collections. IV. The Oligocene and Miocene holotypes of Dorothea Maier (1959). Meyniana 35, 85-137.

Sarjeant, W.A.S. 1984a: Re-study of some dinoflagellate cysts from the Oligocene and Miocene of Germany. Journal of Micropalaeontology 3(2), 73-94.

Sarjeant, W.A.S. 1984b: A restudy of some dinoflagellate cysts and an acritarch from the Malm (Upper Jurassic) of southwest Germany. Palaeontographica Abteilung B 191(5-6), 154-177.

Sarjeant, W.A.S. 1984c: A restudy of some dinoflagellate cyst holotypes in the University of Kiel collections. V. The Danian (Palaeocene) holotypes of Walter Wetzel $(1952,1955)$. Meyniana 36, 121-171.

Sarjeant, W.A.S. 1985a: A restudy of some dinoflagellate cyst holotypes in the University of Kiel collections: VI. Late Cretaceous dinoflagellate cysts and other palynomorphs in the Otto Wetzel collection. Meyniana 37, 129-185.

Sarjeant, W.A.S. 1985b: The German Aptian dinoflagellate cysts of Eisenack (1958): a restudy. Review of Palaeobotany and Palynology 45, 47-106.

Schiøler, P. 1993: New species of dinoflagellate cysts from Maastrichtian-Danian chalks of the Danish North Sea. Journal of Micropalaeontology 12(1), 99-112.

Schumacker-Lambry, J. 1978: Palynologie du Landenien inférieur (Paléocène) à Gelinden-Overbroek/Belgique. Relations entre les microfossiles et le sédiment, 157 pp. Published thesis, Université de Liège, Laboratoire de Paléobotanique et de Paléopalynologie, Liège, Belgium.

Selling, O.H. 1944: A new species of Schizaea from Melanesia and some connected problems. Svensk Botanisk Tidskrift Bd 38(3), 207-225.

Singh, C. 1964: Microflora of the Lower Cretaceous Mannville Group, east-central Alberta. Research Council of Alberta Bulletin 15, $239 \mathrm{pp}$.

Singh, C. 1971: Lower Cretaceous microfloras of the Peace River area, northwestern Alberta. Research Council of Alberta Bulletin 28, 301-542.

Singh, C. 1983: Cenomanian microfloras of the Peace River area, northwestern Alberta. Research Council of Alberta Bulletin 44, 322 pp.

Slimani, H. 1996: Les dinokystes des craies du Campanien-Danien à Hallembaye et Turnhout (Belgique) et à Beutenaken (PaysBas): supplément de systématique. Annales de la Société géologique de Belgique 117(2), 371-391.

Slimani, H. 2001a: New species of dinoflagellate cysts from the Campanian-Danian chalks at Hallembaye and Turnhout (Belgium) and Beutenaken (The Netherlands). Journal of Micropalaeontology 20(1), 1-11.

Slimani, H. 2001b: Les kystes de dinoflagellés du Campanien au Danien dans la région de Maastricht (Belgique, Pays-Bas) et de 
Turnhout (Belgique): biozonation et corrélation avec d'autres régions en Europe occidentale. Geologica et Palaeontologica 35, 161-201.

Sluijs, A., Brinkhuis, H., Williams, G.L. \& Fensome, R.A. 2009: Taxonomic revision of some Cretaceous-Cenozoic spiny organic-walled peridiniacean dinoflagellate cysts. Review of Palaeobotany and Palynology 154(1), 34-53.

Sønderholm, M., Nøhr-Hansen, H., Bojesen-Koefoed, J.A., Dalhoff, F. \& Rasmussen, J.A. 2003: Regional correlation of Mesozoic-Palaeogene sequences across the Greenland-Canada boundary. Danmarks og Grønlands Geologiske Undersøgelse Rapport 2003/25, 184 pp.

Sørensen, A.B. 2006: Stratigraphy, structure and petroleum potential of the Lady Franklin and Maniitsoq basins, offshore southern West Greenland. Petroleum Geoscience 12(3), 221-234.

Srivastava, S.K. 1966: Upper Cretaceous microflora (Maastrichtian) from Scollard, Alberta, Canada. Pollen et Spores 8, 497-552.

Srivastava, S.K. 1970: Pollen biostratigraphy and paleoecology of the Edmonton Formation (Maastrichtian), Alberta, Canada. Palaeogeography, Palaeoclimatology and Palaeoecology 7, 221-276.

Srivastava, S.K. 1972: Systematic description of some spores from the Edmonton Formation (Maastrichtian), Alberta, Canada. Palaeontographica 139B, 1-46,

Srivastava, S.R. \& Rouse, G.E. 1970: Systematic revision of Aquilapollenites Rouse 1957. Canadian Journal of Botany 48, 15911601.

Stancliffe, R.P.W. \& Sarjeant, W.A.S. 1990: The complex chorate dinoflagellate cysts of the Bathonian to Oxfordian (Jurassic): their taxonomy and stratigraphic significance. Micropaleontology 36(3), 197-228.

Stanley, E.A. 1961: A new sporomorph genus from northwestern South Dakota. Pollen et Spores 3(1), 155-162.

Stanley, E.A. 1970: The stratigraphical, biogeographical, paleoautecological and evolutionary significance of the fossil pollen group Triprojectacites. Georgia Academy of Science Bulletin 28, $1-44$.

Storey, M., Duncan, R.A., Pedersen, A.K., Larsen, L.M. \& Larsen, H.C. 1998: ${ }^{40} \mathrm{Ar} /{ }^{39} \mathrm{Ar}$ geochronology of the West Greenland Tertiary volcanic province. Earth and Planetary Science Letters 160, 569-586.

Stover, L.E. 1977: Oligocene and early Miocene dinoflagellates from Atlantic Corehole 5/5B, Blake Plateau. American Association of Stratigraphic Palynologists, Contributions Series 5A, 66-89.

Stover, L.E. \& Evitt, W.R. 1978: Analyses of pre-Pleistocene organic-walled dinoflagellates. Stanford University Publications, Geological Sciences 15, 300 pp.

Stover, L.E. \& Helby, R. 1987: Some Australian Mesozoic microplankton index species. In: Jell, P.A. (ed.): Studies in Australian Mesozoic palynology. Memoirs of the Association of Australasian Palaeontologists 4, 101-134.

Stover, L.E. \& Williams, G.L. 1987: Analyses of Mesozoic and Cenozoic organic-walled dinoflagellates 1977-1985. American Association of Stratigraphic Palynologists, Contributions Series 18, $243 \mathrm{pp}$.
Stover, L.E. \& Williams, G.L. 1995: A revision of the Paleogene dinoflagellate genera Areosphaeridium Eaton 1971 and Eatonicysta Stover and Evitt 1978. Micropaleontology 41(2), 97-141.

Sverdlove, M.S. \& Habib, D. 1974: Stratigraphy and suggested phylogeny of Deflandrea vestita (Brideaux) comb. nov. and Deflandrea echinoidea Cookson and Eisenack. Geoscience and Man 9, 53-62.

Tasch, P., McClure, K. \& Oftedahl, O. 1964: Biostratigraphy and taxonomy of a hystrichosphere - dinoflagellate assemblage from the Cretaceous of Kansas. Micropaleontology 10(2), 189-206.

Thiergart, F. 1940: Die Mikropalaeontologie als pollenanalyse im Dienst der Braunkohlenforschung. Brennstoff-Geologie 13, 1-82.

Thiergart, F. 1950: Pollenfloren aus der tertiären Braunkohle vom Niederrhein. Geologisches Jahrbuch 65, 81-106.

Thomas, J.E. \& Cox, B.M. 1988: The Oxfordian-Kimmeridgian Stage boundary (Upper Jurassic): dinoflagellate cyst assemblages from the Harome Borehole, North Yorkshire, England. Review of Palaeobotany and Palynology 56, 313-326.

Thomson, P.W. \& Pflug, H.D. 1952: Zur Feinstratigraphischen untersuchung von Braunkohlenflozen. Geologisches Jahrbuch, Reihe A 66, 559-576.

Thomson, P.W. \& Pflug, H. 1953: Pollen und Sporen des mitteleuropäischen Tertiärs. Gesamtübersicht über die stratigraphisch und paläontologisch wichtigen Formen. Palaeontographica Abteilung B 94, 1-138.

Thorn, V.C., Riding, J.B. \& Francis, J.E. 2009: The Late Cretaceous dinoflagellate cyst Manumiella - biostratigraphy, systematics and palaeoecological signals in Antarctica. Review of Palaeobotany and Palynology 156, 436-448.

Tralau, H. 1968: Botanical investigations into the fossil flora of Eriksdal in Fyledalen, Scania. II. The Middle Jurassic microflora. Sveriges Geologiska Undersökning Serie C 633, 185 pp.

Tschudy, B.D. 1969: Species of Aquilapollenites and Fibulapollis from two Upper Cretaceous localities in Alaska. U.S. Geological Survey Professional Paper 643-A, 1-17.

Tschudy, B.D. \& Leopold, E.B. 1971: Aquilapollenites (Rouse) Funkhouser-selected Rocky Mountain taxa and their stratigraphic ranges. In: Kosanke, T.M. \& Cross, A.T. (eds): Symposium on palynology of the Late Cretaceous and early Tertiary. Geological Society of America Special Paper 127, 113-167.

Volkheimer, W. 1972: Estudio palinológica de un carbón Calloviano de Neuquén y consideraciones sobre los paleoclimas Jurásicos de la Argentina. Revista del Museo de La Plata (nueva serie) Paleontología 6, 101-157.

Vozzhennikova, T.F. 1960: Paleoalgologicheskaya kharakteristika mezokaynozoyskikh otlozheniy Zapadno - Sibirskoy Nizmennosti. Akademiya Nauk SSSR, Sibirskoe Otdelenie, Institut Geologii i Geofiziki Trudy 1, 7-64.

Vozzhennikova, T.F. 1963: Klass Peridineae (Dinoflagellateae). Peridinei, ili dinoflagellaty. In: Kiselev, A. (ed.): Tip Pyrrophyta. Pirrofitovye Vodorosli. In: Vakhrameeva, V.A., Radchenko, G.P. \& Tachmadzhana, A.L. (eds): Tip Pyrrophyta. Pirrofitovye Vodorosli. Vodorosli, Mochoobraznie, Psilofitovie, Plaonovidnie, Chlenistostebelnie, Paporotniki. In: Orlov, A. (ed.): Osnovy Paleontologii 14, 171-186. 
Vozzhennikova, T.F. 1967: Iskopaemye peridinei Yurskikh, Melovykh i Paleogenovykh otlozheniy SSSR, 347 pp. Izdatelstvo Nauka, Moscow, U.S.S.R.

Wall, D. 1967: Fossil microplankton in deep-sea cores from the Caribbean Sea. Palaeontology 10(1) 95-123.

Wall, D. \& Dale, B. 1971: A reconsideration of living and fossil Pyrophacus Stein 1883 (Dinophyceae). Journal of Phycology 7(3), 221-235.

Wan Chuanbiao \& Qiao Xiuyun 1994: Early Cretaceous nonmarine dinoflagellate assemblages of Well 206 in Sanjiang Basin from Heilongjiang. Acta Palaeontologica Sinica 33(4), 499-508. (In Chinese with English summary.)

Waterfield, J.J. 1989: Stratigraphy, sedimentology and palynology of Cretaceous and Tertiary strata, southwest Bylot Island, Northwest Territories, Canada, 260 pp. Unpublished M.Sc. thesis, Memorial University of Newfoundland, St. Johns, Newfoundland and Labrador, Canada.

Wetzel, O. 1932: Die Typen der baltischen Geschiebefeuersteine, beurteilt nach ihrem Gehalt an Mikrofossilien. Zeitschrift für Geschiebeforschung 8, 129-146.

Wetzel, O. 1933a: Die in organischer Substanz erhaltenen Mikrofossilien des baltischen Kreide-Feuersteins mit einem sedimentpetrographischen und stratigraphischen Anhang. Palaeontographica Abteilung A 78, 1-110.

Wetzel, O. 1933b: Die in organischer Substanz erhaltenen Mikrofossilien des baltischen Kreide-Feuersteins mit einem sedimentpetrographischen und stratigraphischen Anhang. Palaeontographica Abteilung A 77, 141-186.

Wetzel, O. 1961: New microfossils from Baltic Cretaceous flintstones. Micropaleontology 7(3), 337-350.

Weyland, H. \& Krieger, W. 1953: Die Sporen und Pollen der Aachener Kreide und ihre Bedeutung für die Charakterisierung des mittleren Senons. Palaeontographica 95B, 6-29.

Weyland, H. \& Pflug, H.D. 1957: Die Pflanzenreste der pliozänen Braunkohle von Ptolemais in Nordgriechenland. I. Palaeontographica Abteilung B 102(4), 96-109.

Wharton, D.I. 1988: Dinoflagellates from Middle Jurassic sediments of southern Alaska, xiv + 443 pp. Unpublished PhD thesis, Department of Geology, Stanford University, Stanford, California, USA.

White, H.H. 1842: On fossil Xanthidia. Microscopical Journal, London 11, 35-40.

Wiggins, V.D. 1975: The dinoflagellate family Pareodiniaceae: a discussion. Geoscience and Man 11, 95-115.

Wiggins, V.D. 1976: Fossil oculata pollen from Alaska. Geoscience and Man 15, 51-76.

Williams, G.L. 1978: Palynological biostratigraphy, DSDP Sites
367 and 370. In: Lancelot Y. et al. (eds): Deep Sea Drilling Project, Washington, Initial Reports 41, 783-815.

Williams, G.L. \& Brideaux, W.W. 1975: Palynologic analyses of upper Mesozoic and Cenozoic rocks of the Grand Banks, Atlantic continental margin. Geological Survey of Canada Bulletin 236, 163 pp.

Williams, G.L. \& Downie, C. 1966a: Further dinoflagellate cysts from the London Clay. In: Davey, R.J. et al. (eds): Studies on Mesozoic and Cainozoic dinoflagellate cysts. Bulletin of the British Museum (Natural History). Geology. Supplement 3, 215236.

Williams, G.L. \& Downie, C. 1966b: Wetzeliella from the London Clay. In: Davey, R.J. et al. (eds): Studies on Mesozoic and Cainozoic dinoflagellate cysts. Bulletin of the British Museum (Natural History). Geology. Supplement 3, 182-198.

Williams, G.L., Brinkhuis, H., Pearce, M.A., Fensome, R.A. \& Weegink, J.W. 2004: 5. Southern Ocean and global dinoflagellate cyst events compared: Index events for the Late CretaceousNeogene. In: Exon, N.F., Kennett, J.P. \& Malone, M.J. (eds): Ocean Drilling Program Proceedings, Scientific Results 189, 198.

Williams, G.L., Damassa, S.P., Fensome, R.A. \& Guerstein, G.R. 2015: Wetzeliella and its allies - the 'hole' story: a taxonomic revision of the Paleogene dinoflagellate subfamily Wetzelielloideae. Palynology 39(3), 289-344.

Williams, V.E. 1986: Palynological study of the continental shelf sediments of the Labrador Sea, 210 pp. PhD thesis, University of British Columbia, Vancouver, British Columbia, Canada.

Wilson, G.J. 1967a: Microplankton from the Garden Cove Formation, Campbell Island. New Zealand Journal of Botany 5(2), 223-240.

Wilson, G.J. 1967b: Some species of Wetzeliella Eisenack (Dinophyceae) from New Zealand Eocene and Paleocene strata. New Zealand Journal of Botany 5, 469-497.

Wilson, L.R. \& Webster, R.M. 1946: Plant microfossils from a Fort Union Coal of Montana. American Journal of Botany 33, 271278.

Wodehouse, R.P. 1933: Tertiary pollen - II, the oil shales of the Green River Formation. Bulletin of the Torrey Botanical Club 60, 479-524.

Wolff, H. 1934: Mikrofossilien des pliocänen Humodils der Grube Freigericht bei Dettingen a.M. und Vergleich mit älteren Schichten des Tertiärs sowie posttertiären Ablagerungen. Preussischen Geologischen Landesanstalt. Institut für Paläobotanik und Petrographie der Brennsteine Arbeiten 5, 55-86.

Yun Hyesu 1981: Dinoflagellaten aus der Oberkreide (Santon) von Westfalen. Palaeontographica Abteilung B 177, 1-89. 



\section{Plates}

\section{Scale}

The scale bar represents $20 \mu \mathrm{m}$ in all plates.

\section{Explanation}

In the following plates, details concerning the figured specimens are presented in a standardised, abbreviated form grouped in four categories:

\section{Location}

- Locality: mainly offshore wells, but also onshore boreholes and outcrop sections.

- Sample depth (in metres) in wells and boreholes; sample number in outcrop sections, unless specified otherwise.

\section{Sample}

- Type: cs: cuttings sample. os: outcrop section sample. sw: sidewall core sample. cc: conventional core sample.

- Sample number or processing number: All 'P numbers' (e.g. P39553) nos are sample numbers from Canadian wells processed in Canada; the remainder are GGU/GEUS processing numbers of both Canadian and Greenlandic material.

- $\quad$ Slide number/letter.

\section{Optical parameters}

- Microscope identification (relating to following Vernier scale coordinates): A: Leitz Dialux 22 microscope $512742 / 057691$ at the Geological Survey of Denmark and Greenland (GEUS). B: Leica DM 2000 331596-092011 at GEUS. C: Zeiss Axioplan 2 microscope, serial no. 310243 at GSC Atlantic, Dartmouth, Nova Scotia. D: Zeiss Photomicroscope, serial no. 67750 at GSC Atlantic, Dartmouth, Nova Scotia. E: Leitz DM RB (RS232C) at GEUS.

- Vernier coordinates.

- England Finder coordinates.

- Lens magnification and type: bf: bright field. pc: phase contrast.

\section{Repositories}

- CNLOPB: slide curated in the collection of the Canada - Newfoundland and Labrador Offshore Petroleum Board, St. John's, Newfoundland, Canada (no numbers).

- CNSOPB: slide curated in the collection of the Canada - Nova Scotia Offshore Petroleum Board, Dartmouth, Nova Scotia, Canada (no numbers).

- MGUH: slide curated in the type collection of the Geological Museum of the University of Copenhagen (at the time of writing, this material is on long-term loan to GEUS, Øster Voldgade 10, DK-1350 Copenhagen K, Denmark).

- GSC: slide curated in the National Collection of Type Invertebrate and Plant Fossils, Geological Survey of Canada, 601 Booth Street, Ottawa, Ontario, Canada K1A 0E8 (at the time of writing, this material is on long-term loan to GSC Atlantic, Bedford Institute of Oceanography, Dartmouth, Nova Scotia, Canada B2Y 4A2).

- Statoil: slides are stored at the offices of the Statoil petroleum company in Stavanger, Norway (no numbers).

- All nomenclatural types are curated at either the Geological Museum of the University of Copenhagen or at the Geological Survey of Canada, as indicated above.

\section{Previous publication}

The following figures were previously published (in black-and-white) in Nøhr-Hansen (2003): Plate 2, fig. 12; Plate 11, figs 18,19; Plate 15, figs 9-12; Plate 17, fig. 2. In addition, Plate 6 , fig. 1 was previously published in colour in Nøhr-Hansen (1996). 


\section{Plate 1}

Fig. 1. Achilleodinium biformoides, optical section. Location: North Leif I-05, 2040-2050 m. Sample: cs, YD17597, 3. Optical parameters: E, $34.6 \times 17.7, \mathrm{~K} 33 / 1$, $\times 60 \mathrm{bf}$. Repository: GSC 138151.

Fig. 2. Achilleodinium biformoides, same specimen as fig. 1, focussed on ventral surface.

Location: North Leif I-05, 2040-2050 m. Sample: cs, YD17597, 3. Optical parameters: E, $34.6 \times 17.7, \mathrm{~K} 33 / 1, \times 60$ bf.

Repository: GSC 138152.

Fig. 3. Achilleodinium biformoides, dorsal surface.

Location: South Labrador N-79, 1920-1930 m. Sample: cs, P39782, 1. Optical parameters: C, $192 \times 1020$, T31/4, × 50 bf.

Repository: GSC 138115.

Fig. 4. Adnatosphaeridium vittatum, dorsal surface.

Location: Karlsefni A-13, 1627.65-1636.80 m. Sample: cs, P39577, 1.

Optical parameters: D, $179 \times 866, \mathrm{R} 29 / 3, \times 40 \mathrm{pc}$.

Repository: GSC 138013.

Fig. 5. Alisocysta margarita, dorsal surface.

Location: North Leif I-05, 2310-2320 m. Sample: cs, YD17606, 2.

Optical parameters: E, $28.5 \times 6.9, \mathrm{U} 27 / 3, \times 60 \mathrm{bf}$.

Repository: MGUH 31266.

Fig. 6. Alisocysta circumtabulata, ventral view of ventral surface. Location: South Labrador N-79, 3060-3070 m. Sample: cs, P39819, 1. Optical parameters: C, $166 \times 1026, \mathrm{R} 32 / 0-2, \times 50$ bf.

Repository: GSC 138124.

Fig. 7. Alisocysta circumtabulata, same specimen as fig. 6, focussed on dorsal surface.

Location: South Labrador N-79, 3060-3070 m. Sample: cs, P39819, 1. Optical parameters: C, $166 \times 1026, \mathrm{R} 32 / 0-2, \times 50$ bf.

Repository: GSC 138124

Fig. 8. Adnatosphaeridium vittatum, apical view.

Location: South Labrador N-79, 2310-2320 m. Sample: cs, P39795, 1.

Optical parameters: C, $184 \times 1028$, S32/4, × 50 bf.

Repository: GSC 138120.

Fig. 9. Alisocysta margarita, dorsal view.

Location: North Leif I-05, 2370-2380 m. Sample: cs, YD17608, 4.

Optical parameters: E, $38.9 \times 13.6, \mathrm{O} 37 / 2, \times 60$ bf.

Repository: GSC 138161.

Fig. 10. Alterbidinium acutulum, dorsal view of dorsal surface. Location: Karlsefni A-13, 1106.44-1115.58 m. Sample: cs, P39558, 1. Optical parameters: D, $192 \times 918$, T34/2, $\times 40$ pc.

Repository: GSC 138010.
Fig. 11. Alterbidinium acutulum, dorsal surface. Location: Skolp E-07, 1295 m. Sample: cs, YD15594, 3. Optical parameters: A, $49.0 \times 113.2, \mathrm{C} 50 / 1, \times 60 \mathrm{bf}$. Repository: MGUH 31267.

Fig. 12. Alterbidinium biaperturum, dorsal view of dorsal surface. Location: Skolp E-07, 1070 m. Sample: cs, YD15580, 3.

Optical parameters: A, $19.6 \times 96.4, \mathrm{U} 19 / 2, \times 60$ bf. Repository: MGUH 31268.

Fig. 13. Alterbidinium biaperturum, same specimen as fig. 12, dorsal view of ventral surface.

Location: Skolp E-07, 1070 m. Sample: cs, YD15580, 3.

Optical parameters: A, $19.6 \times 96.4, \mathrm{U} 19 / 2, \times 60$ bf.

Repository: MGUH 31268.

Fig. 14. Alterbidinium biaperturum, dorsal view of ventral surface. Location: Skolp E-07, 1250 m. Sample: cs, YD15592, 3.

Optical parameters: A, $25.2 \times 98.0$, S25/3, $\times 60$ bf.

Repository: MGUH 31269.

Fig. 15. Alterbidinium? bicellulum, ventral view. Location: Gjoa O-37, 1620 m. Sample: cs, YD16074, 2. Optical parameters: A, $16.2 \times 100.0, \mathrm{R} 16 / 1, \times 60$ bf. Repository: MGUH 31270.

Fig. 16. Alterbidinium? bicellulum, ventral view. Location: Gjoa O-37, 1620 m. Sample: cs, YD16074, 2. Optical parameters: A, $29.2 \times 93.0, \mathrm{Y} 29 / 0, \times 60$ bf. Repository: MGUH 31271.

Fig. 17. Alterbidinium ioannidesii, dorsal view of ventral surface. Location: Skolp E-07, 2390 m. Sample: cs, YD15666, 2.

Optical parameters: A, $20.1 \times 113.2, \mathrm{~B} 20 / 3, \times 60$ bf. Repository: MGUH 31272.

Fig. 18. Alterbidinium varium, ventral view. Location: Skolp E-07, 1715 m. Sample: cs, JEH15622, 3. Optical parameters: A, $40.0 \times 103.7, \mathrm{M} 40 / 4, \times 60 \mathrm{bf}$. Repository: MGUH 31273.

Fig. 19. Alterbidinium varium, dorsal view. Location: Skolp E-07, 1715 m. Sample: cs, JEH15622, 5.

Optical parameters: A, $26.0 \times 101.6, \mathrm{P} 26 / 3, \times 60 \mathrm{bf}$. Repository: CNLOPB.

Fig. 20. Apectodinium homomorphum, dorsal view. Location: North Leif I-05, 2010-2020 m. Sample: cs, YD17596, 2. Optical parameters: E, $34.1 \times 12.8, \mathrm{O} 33 / 3, \times 60 \mathrm{bf}$. Repository: MGUH 31274. 
Plate 1
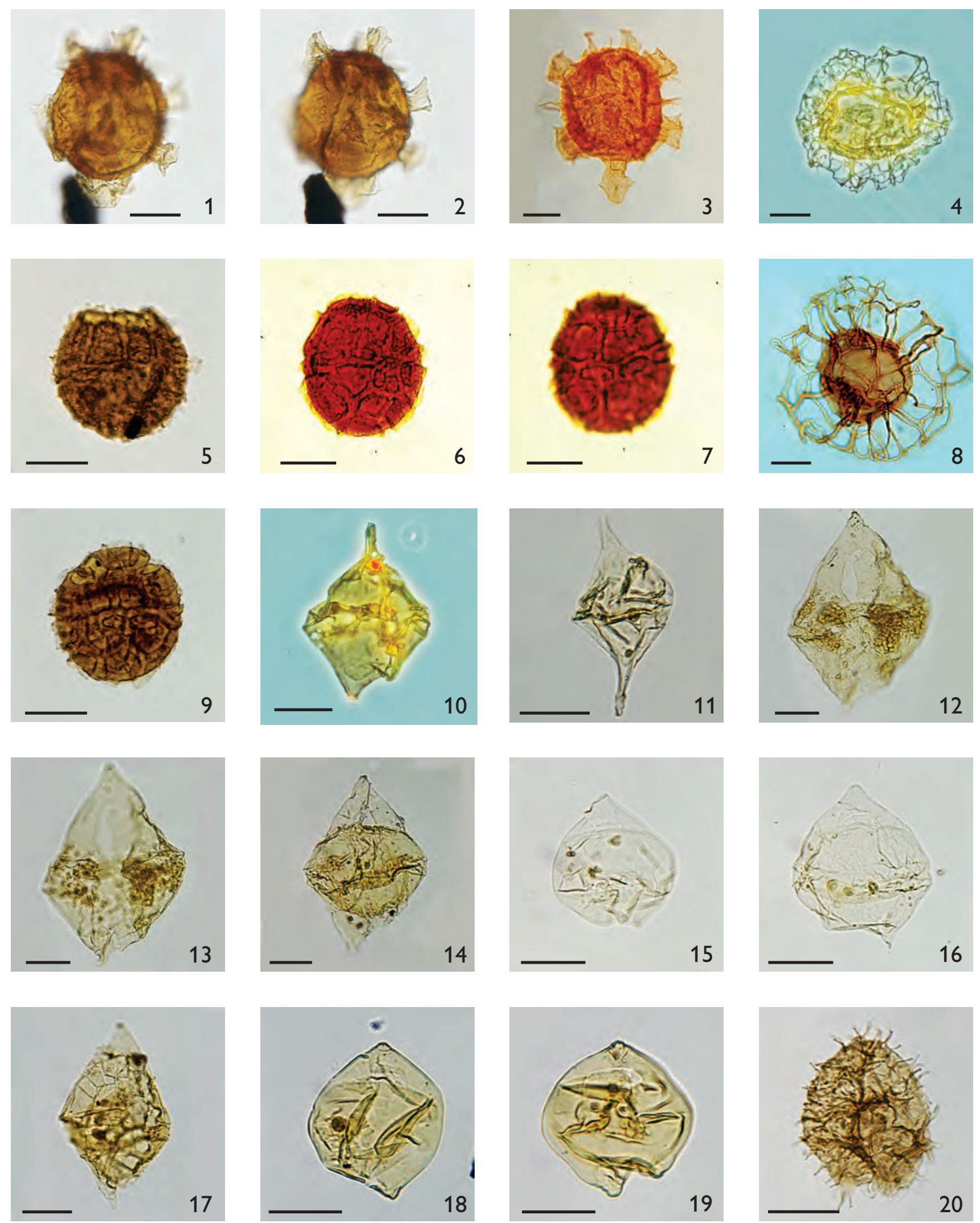


\section{Plate 2}

Fig. 1. Apectodinium parvum, ventral view. Location: North Leif I-05, 2100-2110 m. Sample: cs, YD17599, 3. Optical parameters: E, 22.6× 16.8, K20/4, × 60 bf. Repository: GSC 138154.

Fig. 2. Apectodinium parvum, dorsal view. Location: North Leif I-05, 2070-2080 m. Sample: cs, YD17598, 4. Optical parameters: E, $20.3 \times 23.3$, D18/0, × 60 bf. Repository: MGUH 31275.

Fig. 3. Apectodinium parvum, dorsal view of dorsal surface. Location: Rut H-11, 3335-3345 m. Sample: cs, P39405, 1. Optical parameters: D, $121 \times 1034, \mathrm{M} 46 / 2, \times 40 \mathrm{pc}$. Repository: GSC 137967.

Fig. 4. Apectodinium quinquelatum, dorsal view of ventral surface. Location: North Leif I-05, 2250-2260 m. Sample: cs, YD17604, 3. Optical parameters: E, $55.2 \times 18.9, \mathrm{G} 54 / 4, \times 60 \mathrm{bf}$. Repository: MGUH 31276.

Fig. 5. Aptea polymorpha, dorsal view.

Location: Roberval K-92, 3160-3170 m. Sample: cs, P2008177, 1.

Optical parameters: C, $79 \times 980, \mathrm{H} 27 / 7, \times 50 \mathrm{bf}$.

Repository: GSC 137910.

Fig. 6. Apteodinium australiense, dorso-ventral view. Location: Karlsefni A-13, 969.28-978.42 m. Sample: cs, P39553, 1. Optical parameters: D, $167 \times 898$, Q32/4, × 40 pc. Repository: GSC 138005.

Fig. 7. Apteodinium spiridoides, right lateral view. Location: Karlsefni A-13, 2505.49-2514.63 m. Sample: cs, P39608, 1. Optical parameters: $\mathrm{D}, 171 \times 990, \mathrm{R} 42 / 0, \times 40 \mathrm{pc}$. Repository: GSC 138037.

Fig. 8. Apteodinium spiridoides, right lateral view. Location: Rut H-11, 725-735 m. Sample: cs, P39318, 1. Optical parameters: D, $78 \times 913$, G34/0-3, $\times 40 \mathrm{pc}$. Repository: GSC 137919.

Fig. 9. Areoligera circumsenonensis, ventral view of dorsal surface. Location: Karlsefni A-13, 2615.22-2624.36 m. Sample: cs, P39612, 1. Optical parameters: D, $183 \times 990, S 42 / 1-3, \times 40 \mathrm{pc}$. Repository: GSC 138040.

Fig. 10. Areoligera gippingensis, dorso-ventral view. Location: Karlsefni A-13, 3822.24-3831.38 m. Sample: cs, P39655, 1. Optical parameters: D, $143 \times 930,036 / 1, \times 40$ pc. Repository: GSC 138054.
Fig. 11. Areoligera gippingensis, dorso-ventral view. Location: Gjoa O-37, 2240 m. Sample: cs, YD16095, 2. Optical parameters: E, $52.3 \times 14.2, \mathrm{M} 51 / 4, \times 60 \mathrm{bf}$. Repository: MGUH 31277.

Fig. 12. Areosphaeridium diktyoplokum, dorso-ventral view. Location: Hellefisk-1, 723 m. Sample: sw, YD13709, 2. Optical parameters: A, $38.9 \times 108.4, \mathrm{H} 39 / 4, \times 60$ bf. Repository: MGUH 26473.

Fig. 13. Atopodinium cf. haromense, dorso-ventral view. Location: Skolp E-07, 1550 m. Sample: cs, JEH15611, 5. Optical parameters: A, $35.0 \times 95.5, \mathrm{~V} 35 / 1, \times 60$ bf. Repository: MGUH 31278.

Fig. 14. Axiodinium augustum, dorso-ventral view. Location: North Leif I-05, 2250-2260 m. Sample: cs, YD17604, 3. Optical parameters: E, $43.0 \times 21.6, \mathrm{E} 42 / 1, \times 60 \mathrm{bf}$. Repository: MGUH 31279.

Fig. 15. Axiodinium augustum, dorso-ventral view, same specimen as fig. 14, focussed on antapical part.

Location: North Leif I-05, 2250-2260 m. Sample: cs, YD17604, 3.

Optical parameters: E, $43.0 \times 21.6, \mathrm{E} 42 / 1$, $\times 60$ bf.

Repository: MGUH 31279.

Fig. 16. Batiacasphaera micropapillata, dorso-ventral view. Location: Rut H-11, 845-855 m. Sample: cs, P39322, 1.

Optical parameters: D, $93 \times 1020, \mathrm{~J} 45 / 0, \times 40 \mathrm{pc}$.

Repository: GSC 137924.

Fig. 17. Batioladinium jaegeri, ventral view of ventral surface. Location: Skolp E-07, 1655 m. Sample: cs, JEH15618, 3. Optical parameters: A, $45.7 \times 107.9$, H46/4, × 60 bf. Repository: MGUH 31281.

Fig. 18. Callaiosphaeridium asymmetricum, apical-antapical view. Location: Skolp E-07, 1535 m. Sample: cs, JEH15610, 3.

Optical parameters: A, $33.7 \times 98.8, \mathrm{R} 34 / 3, \times 60$ bf.

Repository: MGUH 31282.

Fig. 19. Cerebrocysta bartonensis, left lateral view. Location: Ogmund E-72, 1336 m. Sample: sw, JEH15552, 2. Optical parameters: A, $39.8 \times 107.7, \mathrm{H} 40 / 4, \times 60$ bf. Repository: MGUH 31283.

Fig. 20. Cerebrocysta bartonensis, left lateral view, same specimen as fig. 19, focussed on operculum, within cyst.

Location: Ogmund E-72, 1336 m. Sample: sw, JEH15552, 2.

Optical parameters: A, $39.8 \times 107.7, \mathrm{H} 40 / 4, \times 60$ bf.

Repository: MGUH 31283. 


\section{Plate 2}
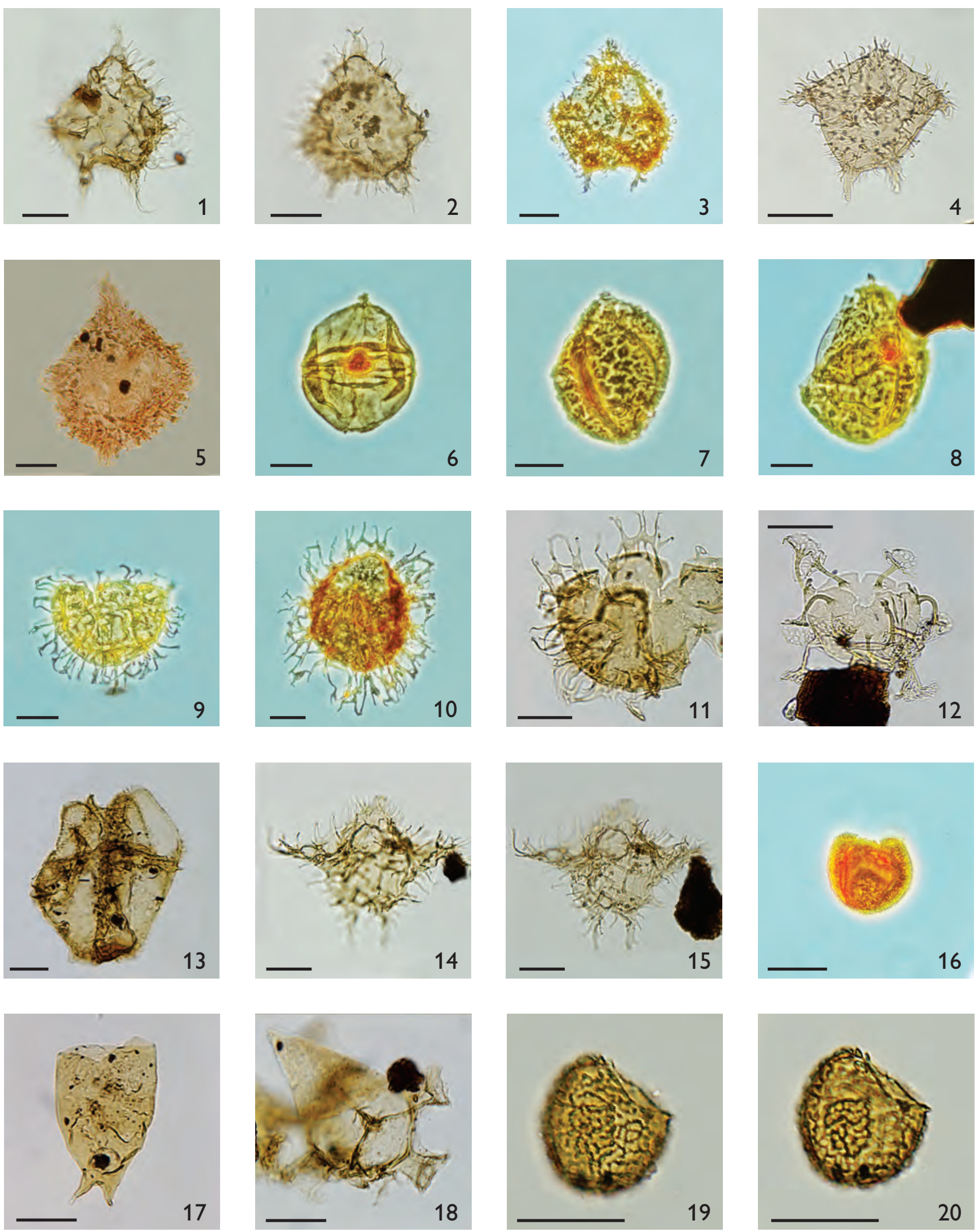


\section{Plate 3}

Fig. 1. Cerodinium diebelii, dorso-ventral view. Location: Roberval K-92, 3160-3170 m. Sample: cs, P2008177, 1. Optical parameters: C, $130 \times 918, \mathrm{~N} 20 / 0, \times 40 \mathrm{bf}$. Repository: GSC 137909.

Fig. 2. Cerodinium diebelii, ventral view of dorsal surface. Location: Roberval K-92, 2500-2510 m. Sample: cs, P19229, 1. Optical parameters: C, $100 \times 1018, \mathrm{~K} 31 / 0-2$, $\times 50$ bf. Repository: GSC 137905.

Fig. 3. Cerodinium diebelii, dorsal view of dorsal surface. Location: North Leif I-05, 2370-2380 m. Sample: cs, YD17608, 2. Optical parameters: E, $39.6 \times 16.1$, L38/2, × 60 bf. Repository: MGUH 31284.

Fig. 4. Cerodinium diebelii, dorso-ventral view. Location: North Leif I-05, 2520-2530 m. Sample: cs, YD17613, 3. Optical parameters: E, $23.8 \times 18.7, \mathrm{H} 22 / 3, \times 60$ bf. Repository: MGUH 31285.

Fig. 5. Cannosphaeropsis passio, oblique antapical view. Location: Qulleq-1, 1847 m. Sample: sw, YD14581, 4. Optical parameters: A, $38.4 \times 108.0, \mathrm{~J} 38 / 2, \times 40 \mathrm{bf}$. Repository: Statoil.

Fig. 6. Cerebrocysta magna, oblique right lateral view. Location: Qulleq-1, $1862.1 \mathrm{~m}$. Sample: sw, YD14587, 3. Optical parameters: A, $29.8 \times 100.7, \mathrm{Q} 30 / 3, \times 60 \mathrm{bf}$. Repository: Statoil/MGUH 26505.

Fig. 7. Cerodinium glabrum, dorsal surface. Location: Gilbert F-53, 3420-3430 m. Sample: cs, P17040, 1. Optical parameters: C, $158 \times 1010, \mathrm{~L} 30 / 2, \times 50 \mathrm{bf}$. Repository: GSC 137887.

Fig. 8. Cerodinium glabrum, dorsal surface. Location: Gjoa O-37, 2400 m. Sample: cs, YD16097, 2. Optical parameters: E, $21.4 \times 25.3$, B19/2, × 60 bf. Repository: MGUH 31286.

Fig. 9. Cerodinium kangiliense, dorsal view of dorsal surface. Location: Skolp E-07, 1460 m. Sample: cs, YD15605, 3. Optical parameters: A, $52.0 \times 102.8, \mathrm{~N} 53 / 3, \times 60 \mathrm{bf}$. Repository: MGUH 31287.

Fig. 10. Cerodinium kangiliense, dorsal view, same specimen as fig. 9, focussed on ventral surface.

Location: Skolp E-07, 1460 m. Sample: cs, YD15605, 3.

Optical parameters: A, $52.0 \times 102.8$, N53/3, $\times 60$ bf. Repository: MGUH 31287.
Fig. 11. Cerodinium striatum, dorso-ventral view of dorsal surface. Location: Gilbert F-53, 2410-2420 m. Sample: cs, P39493, 1.

Optical parameters: C, $70 \times 1040, \mathrm{G} 34 / 1, \times 50$ bf.

Repository: GSC 137983.

Fig. 12. Cerodinium striatum, dorso-ventral view.

Location: Rut H-11, 2765-2775 m. Sample: cs, P39386, 1.

Optical parameters: D, $65 \times 869, \mathrm{~F} 29 / 2, \times 40 \mathrm{pc}$.

Repository: GSC 137955.

Fig. 13. Cerodinium speciosum, dorso-ventral view of dorsal surface. Location: Hekja O-71, 4510-4520 m. Sample: cs, P20645, 1.

Optical parameters: C, $50 \times 1007, \mathrm{E} 30 / 0, \times 50 \mathrm{bf}$.

Repository: GSC 137915.

Fig. 14. Chatangiella madura, dorsal view of dorsal surface.

Location: Skolp E-07, 1580 m. Sample: cs, JEH15613, 3.

Optical parameters: A, $31.0 \times 112.8$, C31/4, × 60 bf.

Repository: MGUH 31288.

Fig. 15. Chatangiella madura, dorsal view, same specimen as fig. 14, focussed on optical section.

Location: Skolp E-07, 1580 m. Sample: cs, JEH15613, 3.

Optical parameters: A, $31.0 \times 112.8$, C31/4, × 60 bf.

Repository: MGUH 31288.

Fig. 16. Chatangiella tripartita, dorsal view of dorsal surface.

Location: South Labrador N-79, 1230-1240 m. Sample: cs, P39761, 1.

Optical parameters: C, $178 \times 988, \mathrm{~S} 28 / 0-2, \times 50 \mathrm{bf}$.

Repository: GSC 138081.

Fig. 17. Chiropteridium galea, dorsal view.

Location: Karlsefni A-13, 1051.57-1060.72 m. Sample: cs, P39556, 1.

Optical parameters: D, $228 \times 1029, \mathrm{X} 46 / 1, \times 40 \mathrm{pc}$.

Repository: GSC 138008.

Fig. 18. Chiropteridium galea, ventral view of ventral surface.

Location: Karlsefni A-13, 1079.01-1088.15 m. Sample: cs, P39557, 1.

Optical parameters: D, $170 \times 991, \mathrm{R} 42 / 1, \times 40 \mathrm{pc}$.

Repository: GSC 138009.

Fig. 19. Chiropteridium galea, ventral view.

Location: Karlsefni A-13, 1161.30-1170.45 m. Sample: cs, P39560, 1.

Optical parameters: D, $172 \times 889, \mathrm{R} 31 / 2, \times 40 \mathrm{pc}$.

Repository: GSC 138011.

Fig. 20. Chatangiella tripartita, ventral view of dorsal surface. Location: Karlsefni A-13, 2267.74-2276.88 m. Sample: cs, P39599, 1. Optical parameters: D, $192 \times 926, \mathrm{~T} 35 / 0, \times 40 \mathrm{pc}$.

Repository: GSC 138029. 
Plate 3
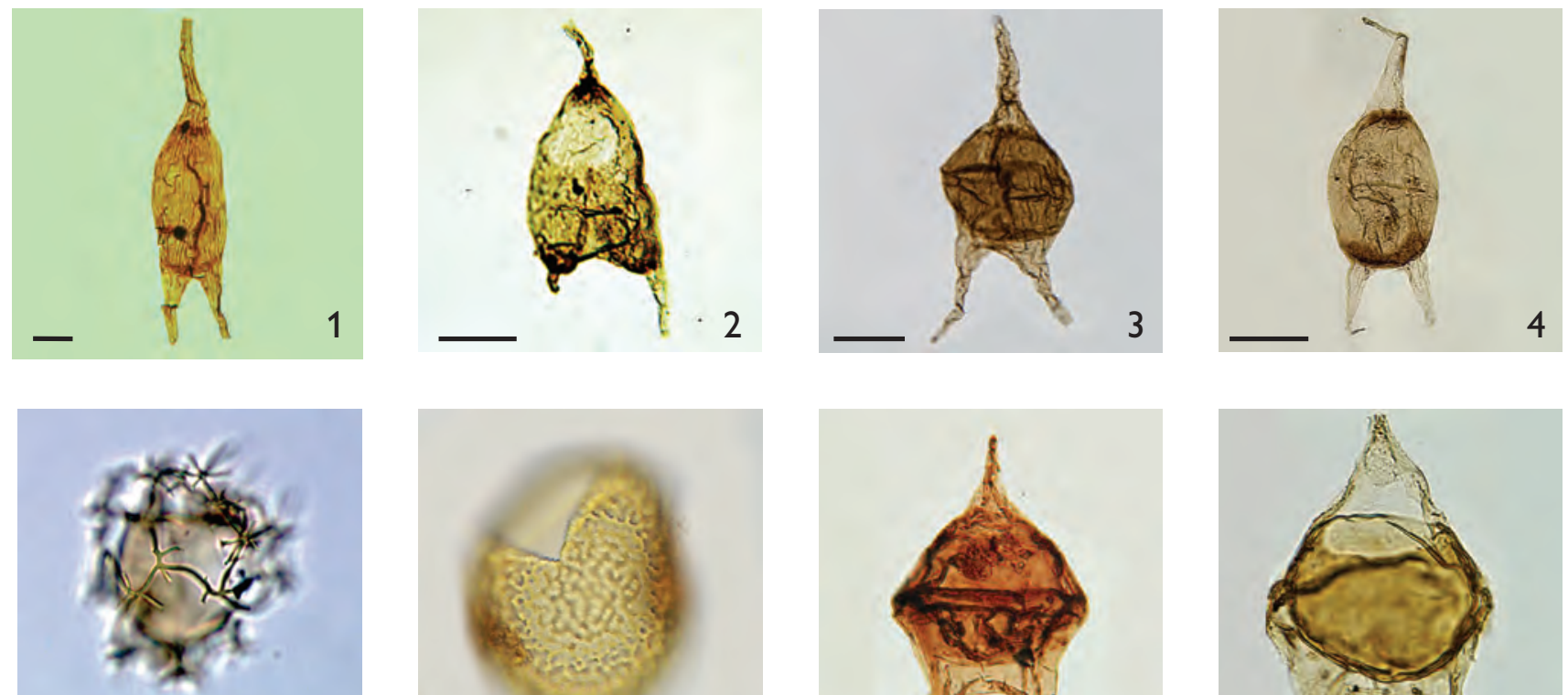

5
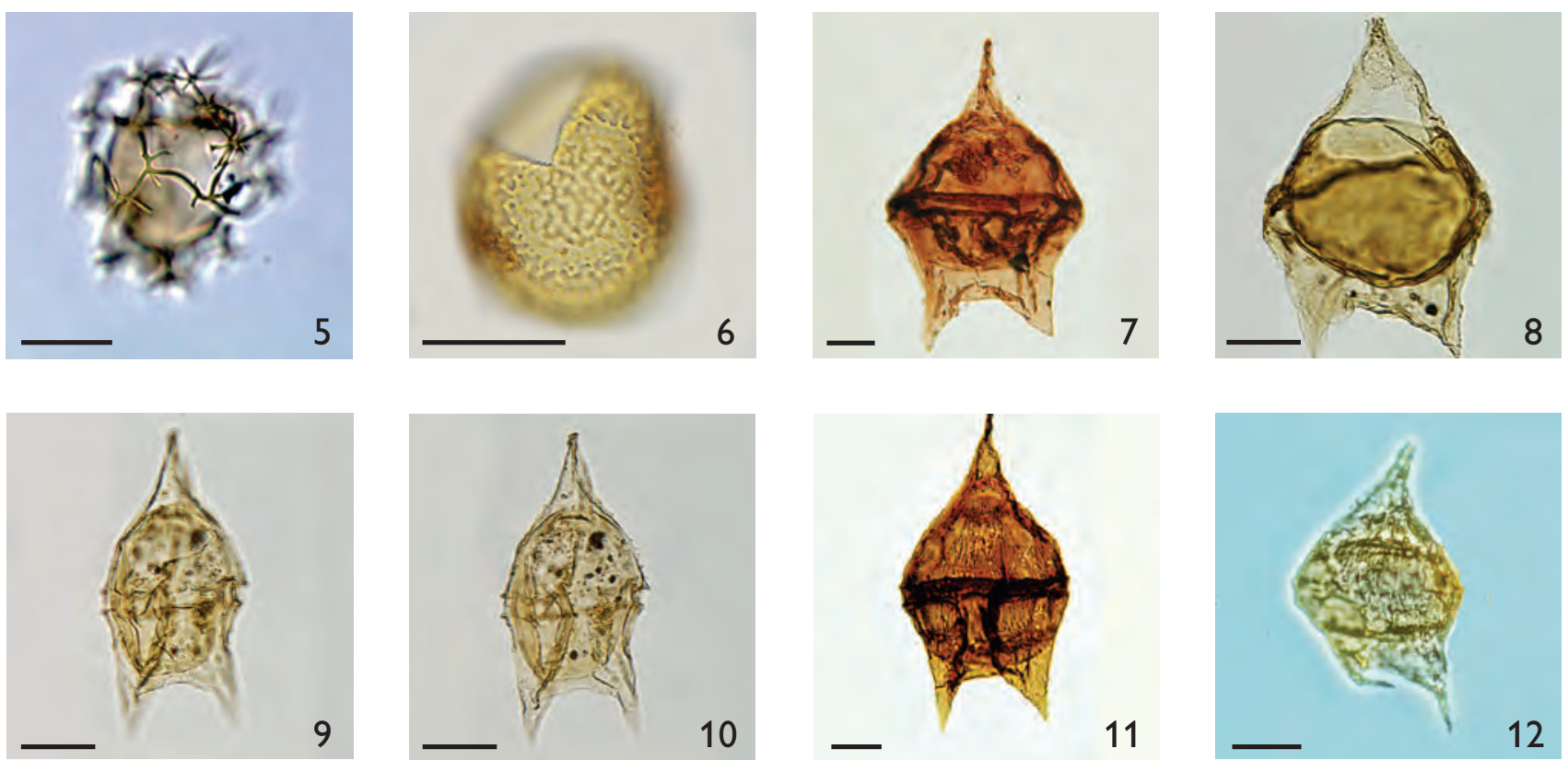

11

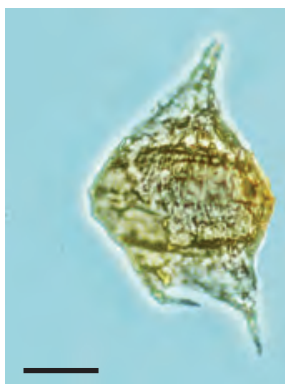

12
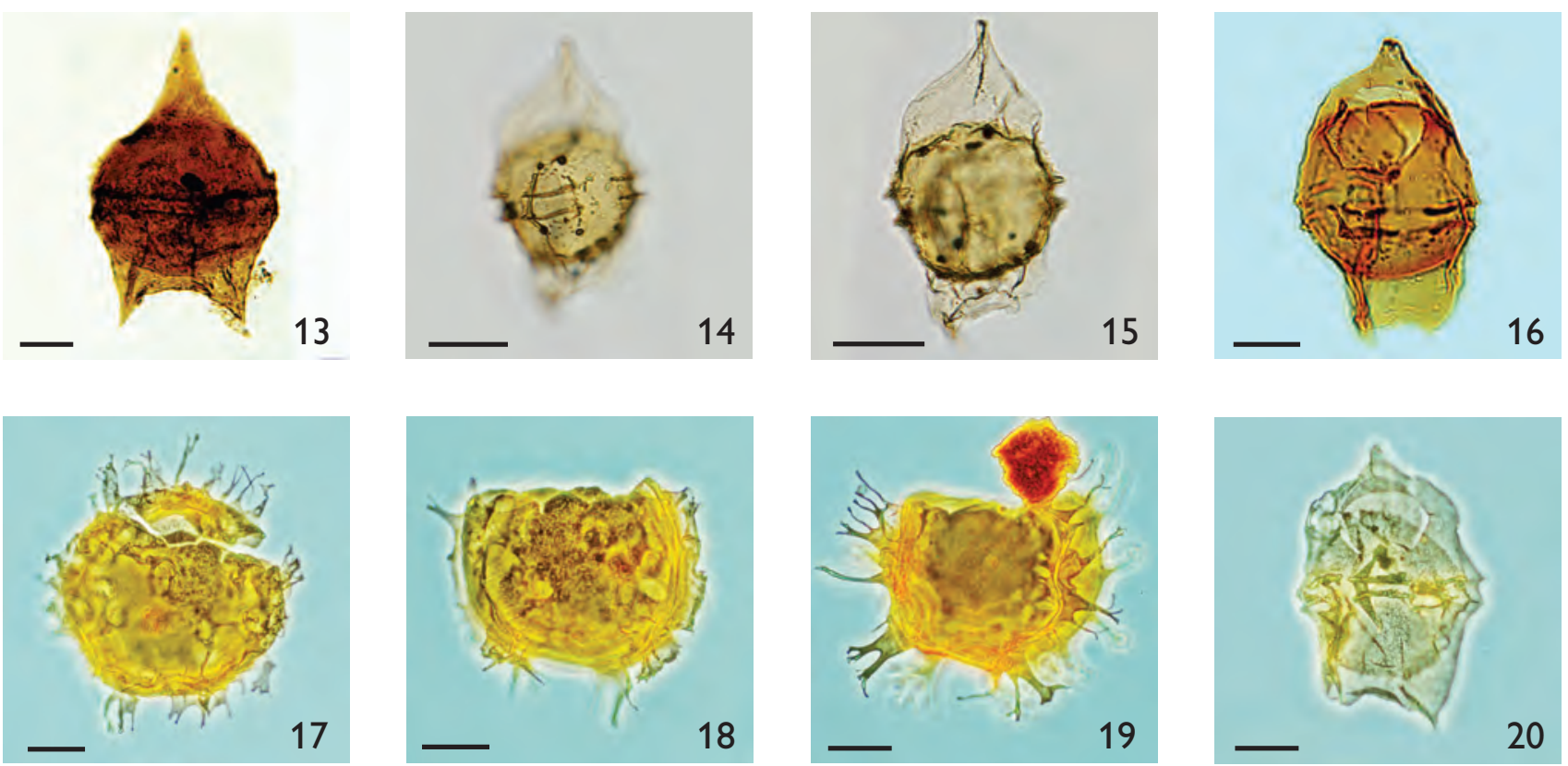


\section{Plate 4}

Fig. 1. Chiropteridium gilbertii sp. nov., dorso-ventral view. Location: South Labrador N-79, 1440-1450 m. Sample: cs, P39768, 1. Optical parameters: C, $56 \times 1028$, E32/4, × 50 bf. Repository: GSC 138112.

Fig. 2. Chiropteridium gilbertii sp. nov., ventral view of dorsal surface. Location: South Labrador N-79, 1560-1570 m. Sample: cs, P39772, 1. Optical parameters: C, $168 \times 1031, \mathrm{R} 33 / 1, \times 50$ bf. Repository: GSC 138113.

Fig. 3. Chiropteridium gilbertii sp. nov., ventral view, same specimen as fig. 2, focussed on ventral surface.

Location: South Labrador N-79, 1560-1570 m. Sample: cs, P39772, 1. Optical parameters: C, $168 \times 1031, \mathrm{R} 33 / 1, \times 50 \mathrm{bf}$.

Repository: GSC 138113.

Fig. 4. Chiropteridium gilbertii sp. nov., holotype, ventral view. Location: Gilbert F-53, 1600-1610 m. Sample: cs, P39466, 1. Optical parameters: C, $174 \times 1060, \mathrm{R} 36 / 3, \times 50 \mathrm{bf}$. Repository: GSC 137976.

Fig. 5. Chlamydophorella nyei, left lateral view. Location: South coast Bylot Island, section B, $1.8 \mathrm{~m}$ above base (sample HFB09-17A). Sample: os, P5148-4, C.

Optical parameters: C, $193 \times 901, \mathrm{H} 57 / 0-1, \times 50$ bf. Repository: GSC 138130.

Fig. 6. Chlamydophorella cf. nyei, dorso-ventral view. Location: Ogmund E-72, 1620 m. Sample: cs, YD15740, 5. Optical parameters: A, $19.5 \times 110.5$, F19/2, $\times 60$ bf. Repository: GSC 138145.

Fig. 7. Chlamydophorella cf. nyei, right lateral view. Location: North Leif I-05, 2670-2680 m. Sample: cs, YD17618, 2. Optical parameters: E, $18.6 \times 19.5, \mathrm{G} 16 / 2, \times 60 \mathrm{bf}$. Repository: MGUH 31289.

Fig. 8. Chlamydophorella cf. nyei, dorso-ventral view. Location: Skolp E-07, 1685 m. Sample: cs, JEH15620, 3. Optical parameters: $\mathrm{B}, 30.47 \times 5.36, \mathrm{X} 32 / 1, \times 60 \mathrm{bf}$. Repository: MGUH 31290.

Fig. 9. Charlesdowniea coleothrypta, ventral view of ventral surface. Location: Gilbert F-53, 2050-2060 m. Sample: cs, P39481, 1. Optical parameters: C, $57 \times 1014, \mathrm{E} 31 / 3, \times 50 \mathrm{bf}$. Repository: GSC 137981.

Fig. 10. Cleistosphaeridium elegantulum sp. nov., apical view. Location: Karlsefni A-13, 2203.73-2212.87 m. Sample: cs, P39597, 1. Optical parameters: D, $122 \times 866, \mathrm{M} 29 / 0-1, \times 40$ pc. Repository: GSC 138026.
Fig. 11. Cleistosphaeridium elegantulum sp. nov., oblique apical view. Location: Karlsefni A-13, 2203.73-2212.87 m. Sample: cs, P39597, 1. Optical parameters: D, $230 \times 894, \mathrm{X} 32 / 0, \times 40 \mathrm{pc}$. Repository: GSC 138027.

Fig. 12. Cleistosphaeridium elegantulum sp. nov., holotype, dorsoventral view.

Location: Karlsefni A-13, 2286.03-2295.17 m. Sample: cs, P39600, 1. Optical parameters: D, $179 \times 1017$, S44/2, $\times 40$ pc.

Repository: GSC 138033.

Fig. 13. Cleistosphaeridium palmatum sp. nov., holotype, dorsal view of optical section.

Location: Roberval K-92, 2450-2460 m. Sample: cs, P17706, 1.

Optical parameters: C, $69 \times 1006$, G30/0-2, × 50 bf.

Repository: GSC 137897.

Fig. 14. Cleistosphaeridium palmatum sp. nov., holotype, dorsal view, focussed on dorsal surface.

Location: Roberval K-92, 2450-2460 m. Sample: cs, P17706, 1.

Optical parameters: C, $69 \times 1006, \mathrm{G} 30 / 0-2, \times 50$ bf.

Repository: GSC 137897.

Fig. 15. Cleistosphaeridium palmatum sp. nov., dorso-ventral view. Location: Rut H-11, 3005-3015 m. Sample: cs, P39394, 1.

Optical parameters: D, $141 \times 905, \mathrm{O} 33 / 1, \times 40 \mathrm{pc}$. Repository: GSC 137960.

Fig. 16. Cleistosphaeridium palmatum sp. nov., dorso-ventral view.

Location: Rut H-11, 3275-3285 m. Sample: cs, P39403, 1.

Optical parameters: D, $140 \times 925, \mathrm{~N} 35 / 3-4, \times 40 \mathrm{pc}$.

Repository: GSC 137966.

Fig. 17. Chytroeisphaeridia hadra sp. nov., dorsal surface showing the archaeopyle.

Location: Roberval K-92, 1700-1710 m. Sample: cs, P17681, 1.

Optical parameters: C, $48 \times 1017, \mathrm{E} 30 / 2, \times 50$ bf.

Repository: GSC 137888.

Fig. 18. Chytroeisphaeridia hadra, sp. nov., holotype, optical section view.

Location: Roberval K-92, 3120-3140 m. Sample: cs, P17728, 1.

Optical parameters: C, $195 \times 1098, \mathrm{U} 40 / 1, \times 50$ bf.

Repository: GSC 137902.

Fig. 19. Cleistosphaeridium diversispinosum, dorso-ventral view. Location: Karlsefni A-13, 969.28-978.42 m. Sample: cs, P39553, 1.

Optical parameters: D, $163 \times 971, \mathrm{Q} 40 / 0, \times 40 \mathrm{pc}$.

Repository: GSC 138004.

Fig. 20. Cleistosphaeridium diversispinosum, operculum. Location: Karlsefni A-13, 2203.73-2212.87 m. Sample: cs, P39597, 1. Optical parameters: D, $115 \times 972, \mathrm{~L} 40 / 0, \times 40 \mathrm{pc}$.

Repository: GSC 138025. 
Plate 4
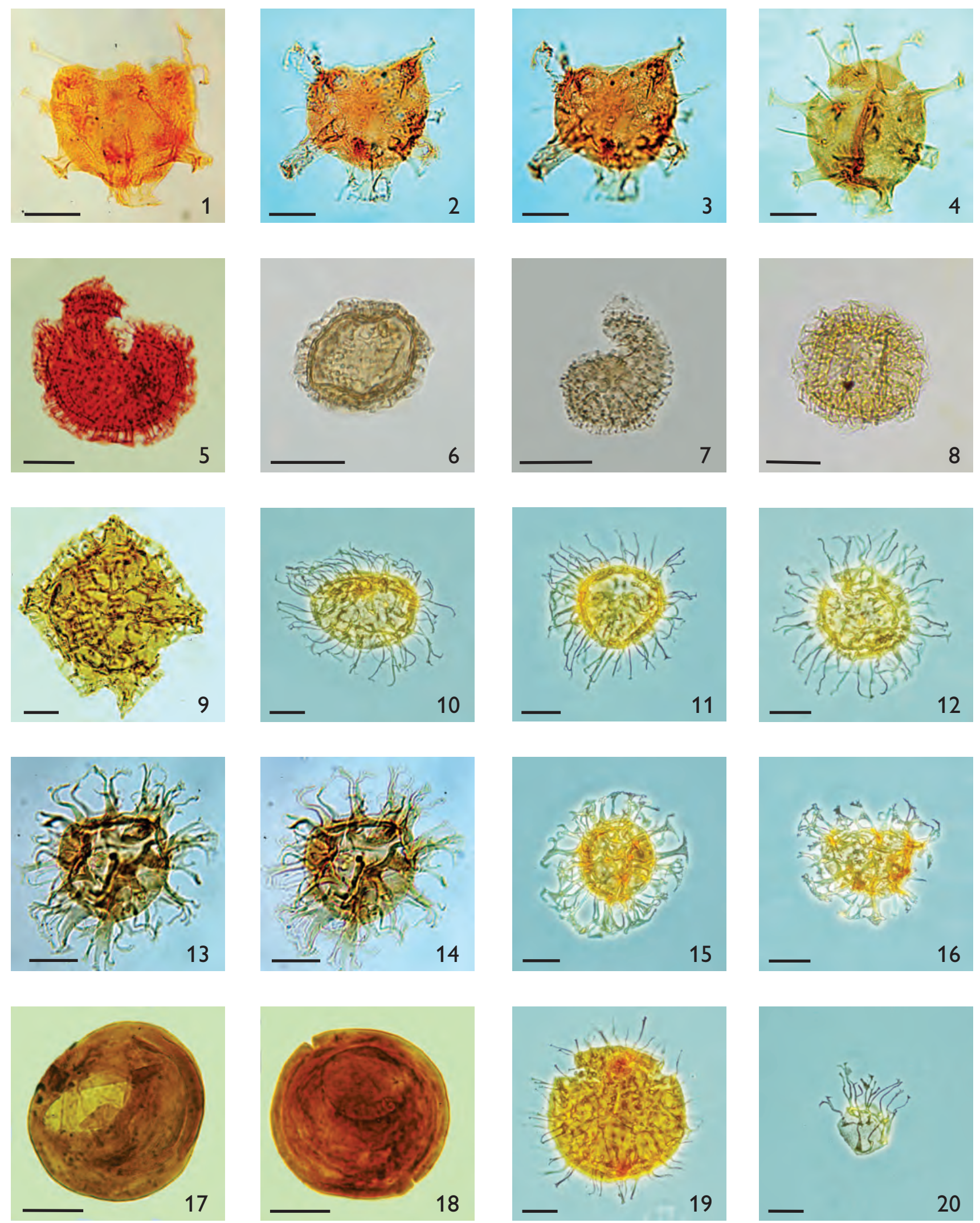


\section{Plate 5}

Fig. 1. Cleistosphaeridium polypetellum, dorso-ventral view. Location: Karlsefni A-13, 2944.40-2953.55 m. Sample: cs, P39624, 1. Optical parameters: D, $215 \times 1017, \mathrm{~V} 44 / 4, \times 40 \mathrm{pc}$. Repository: GSC 138047.

Fig. 2. Cleistosphaeridium polypetellum. Location: Karlsefni A-13, 3054.13-3063.28 m. Sample: cs, P39628, 1. Optical parameters: D, $151 \times 896, \mathrm{P} 32 / 1-2, \times 40 \mathrm{pc}$. Repository: GSC 138048.

Fig. 3. Cordosphaeridium delimurum, dorso-ventral view. Location: Karlsefni A-13, 2807.24-2816.39 m. Sample: cs, P39619, 1. Optical parameters: D, $166 \times 976, \mathrm{Q} 40 / 0-4, \times 40 \mathrm{pc}$. Repository: GSC 138046.

Fig. 4. Cordosphaeridium delimurum, dorso-ventral view, same specimen as fig. 3.

Location: Karlsefni A-13, 2807.24-2816.39 m. Sample: cs, P39619, 1. Optical parameters: D, $166 \times 976, \mathrm{Q} 40 / 0-4, \times 40 \mathrm{pc}$. Repository: GSC 138046.

Fig. 5. Cordosphaeridium fibrospinosum, oblique apical view. Location: Karlsefni A-13, 3989.88-3999.02 m. Sample: cs, P39661, 1. Optical parameters: D, $122 \times 980, \mathrm{M} 41 / 0-1, \times 40 \mathrm{pc}$. Repository: GSC 138060.

Fig. 6. Cordosphaeridium fibrospinosum, dorsal view. Location: Karlsefni A-13, 3989.88-3999.02 m. Sample: cs, P39661, 1. Optical parameters: D, $126 \times 897, \mathrm{M} 32 / 0, \times 40 \mathrm{pc}$. Repository: GSC 138061.

Fig. 7. Cordosphaeridium cantharellus, right lateral view. Location: Rut H-11, 755-765 m. Sample: cs, P39319, 1. Optical parameters: D, $110 \times 978, \mathrm{~L} 40 / 2, \times 40 \mathrm{pc}$. Repository: GSC 137922.

Fig. 8. Cordosphaeridium funiculatum, left lateral view. Location: Ralegh N-18, 1525 m. Sample: cs, YD16219, 2. Optical parameters: E, $43.3 \times 23.8$, C42/1, × $60 \mathrm{bf}$. Repository: MGUH 31291.

Fig. 9. Cordosphaeridium gracile, dorsal surface. Location: Karlsefni A-13, 3081.57-3090.71 m. Sample: cs, P39629, 1. Optical parameters: D, $171 \times 1030, \mathrm{R} 46 / 0, \times 40 \mathrm{pc}$. Repository: GSC 138049.

Fig. 10. Cordosphaeridium inodes, dorsal surface. Location: Karlsefni A-13, 3931.97-3941.11 m. Sample: cs, P39659, 1. Optical parameters: D, $97 \times 910, \mathrm{~J} 34 / 1-3, \times 40 \mathrm{pc}$. Repository: GSC 138059 .
Fig. 11. Dapsilidinium pseudoinsertum sp. nov., dorso-ventral view. Location: Karlsefni A-13, 2697.51-2706.66 m. Sample: cs, P39615, 1. Optical parameters: D, $98 \times 946, \mathrm{~J} 37 / 4, \times 40 \mathrm{pc}$. Repository: GSC 138043.

Fig. 12. Dapsilidinium pseudoinsertum sp. nov., holotype, dorsoventral view.

Location: Rut H-11, 2825-2835 m. Sample: cs, P39388, 1.

Optical parameters: D, $196 \times 1051, \mathrm{U} 48 / 1-2, \times 40 \mathrm{pc}$.

Repository: GSC 137957.

Fig. 13. Dapsilidinium pseudocolligerum.

Location: Gilbert F-53, 2020-2030 m. Sample: cs, P39480, 1.

Optical parameters: C, $45 \times 1008$, D30/0-4, × 50 bf.

Repository: GSC 137980.

Fig. 14. Dapsilidinium simplex, dorso-ventral view. Location: Rut H-11, 3845-3855 m. Sample: cs, P39421, 1.

Optical parameters: D, $165 \times 921, \mathrm{Q} 35 / 3, \times 40 \mathrm{pc}$.

Repository: GSC 137974.

Fig. 15. Deflandrea denticulata, dorso-ventral view of dorsal surface. Location: Karlsefni A-13, 4038.65-4047.79 m. Sample: cs, P39663, 1. Optical parameters: D, $165 \times 1014, \mathrm{Q} 44 / 0, \times 40 \mathrm{pc}$. Repository: GSC 138065.

Fig. 16. Deflandrea denticulata, dorso-ventral view of ventral surface. Location: Karlsefni A-13, 4038.65-4047.79 m. Sample: cs, P39663, 1. Optical parameters: D, $60 \times 1068, \mathrm{E} 50 / 3, \times 40 \mathrm{pc}$. Repository: GSC 138064.

Fig. 17. Deflandrea borealis sp. nov., dorso-ventral view. Location: Karlsefni A-13, 2697.51-2706.66 m. Sample: cs, P39615, 1. Optical parameters: D, $169 \times 929, \mathrm{Q} 35 / 4, \times 40 \mathrm{pc}$. Repository: GSC 138044.

Fig. 18. Deflandrea borealis sp. nov., dorso-ventral view. Location: Rut H-11, 2915-2925 m. Sample: cs, P39391, 1. Optical parameters: D, $198 \times 883, \mathrm{U} 31 / 1, \times 40 \mathrm{pc}$. Repository: GSC 137959.

Fig. 19. Deflandrea borealis sp. nov., holotype, dorso-ventral view. Location: Rut H-11, 3095-3105 m. Sample: cs, P39397, 1.

Optical parameters: D, $189 \times 986, \mathrm{~T} 41 / 2, \times 40 \mathrm{pc}$. Repository: GSC 137964.

Fig. 20. Deflandrea borealis sp. nov., dorso-ventral view. Location: Gilbert F-53, 1810-1820 m. Sample: cs, P39473, 1. Optical parameters: C, $175 \times 1014, \mathrm{R} 31 / 3, \times 50 \mathrm{bf}$. Repository: GSC 137977. 
Plate 5
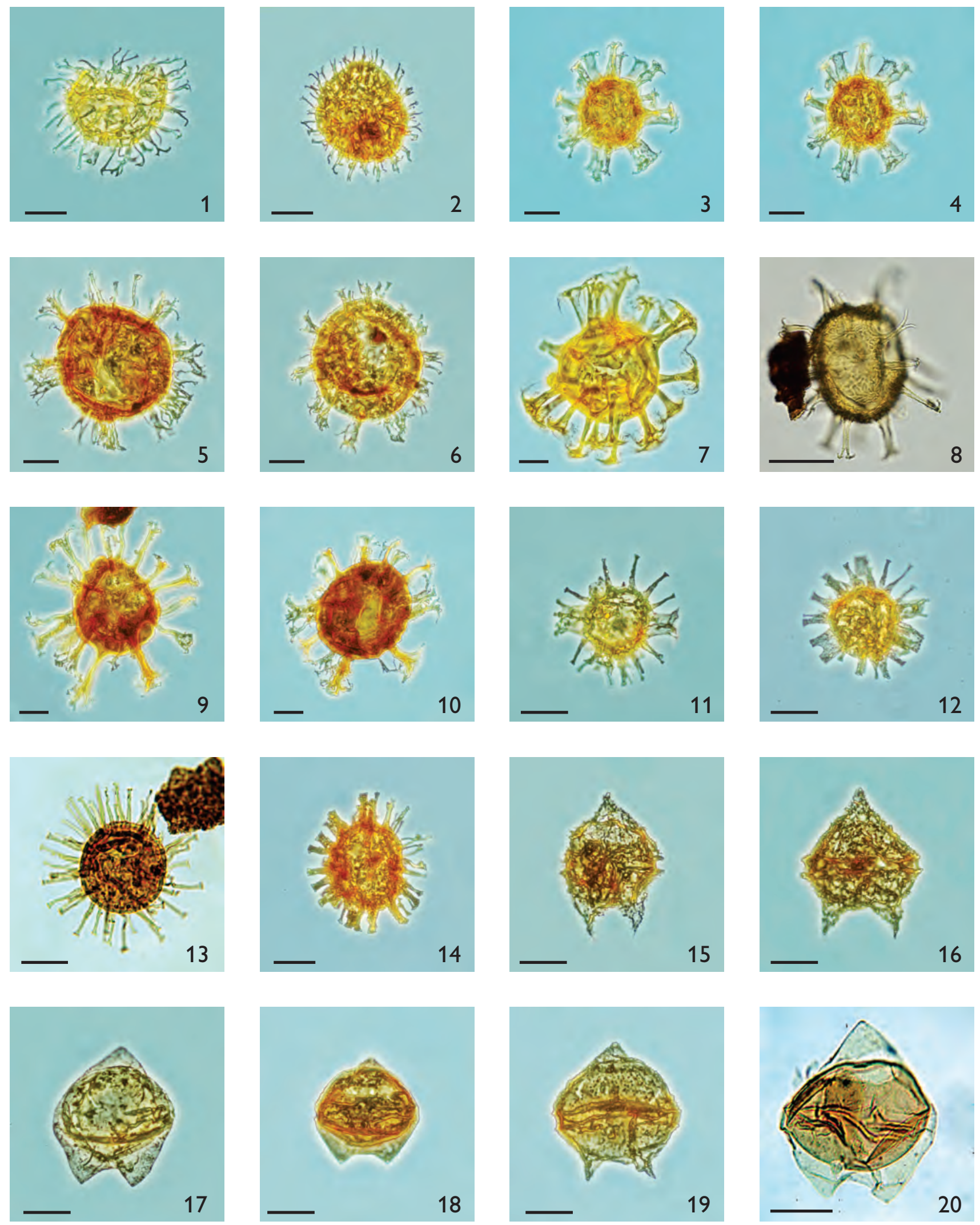


\section{Plate 6}

Fig. 1. Deflandrea galeata, dorso-ventral view of dorsal surface. Location: Annertuneq, 388 m, GGU366591. Sample: os, C402-G, 5. Optical parameters: A, $56.1 \times 112.8$, B556/4, × 60 bf. Repository: MGUH 23924.

Fig. 2. Deflandrea majae, ventral view of ventral surface. Location: Skolp E-07, 1055 m. Sample: cs, YD15579, 4. Optical parameters: A, $45.7 \times 96.9$, T46/4, × 60 bf. Repository: GSC 138142.

Fig. 3. Deflandrea oebisfeldensis, dorso-ventral view of ventral surface. Location: Hekja O-71, 3360 m. Sample: cs, JEH16039, 3.

Optical parameters: E, $32.1 \times 5.6$, W31/1, × 60 bf. Repository: MGUH 31292.

Fig. 4. Deflandrea phosphoritica, dorso-ventral view. Location: Snorri J-90, 2249.45-2256.6 m. Sample: cs, P9747, 10. Optical parameters: C, $220 \times 1035$, W33/0, × 50 bf. Repository: GSC 138136.

Fig. 5. Diphyes brevispinum, dorso-ventral view. Location: South Labrador N-79, 1920-1930 m. Sample: cs, P39782, 1. Optical parameters: C, $118 \times 1030, \mathrm{M} 32 / 2-\mathrm{M} 33 / 1, \times 50$ bf. Repository: GSC 138114.

Fig. 6. Diphyes brevispinum, dorso-ventral view. Location: South Labrador N-79, 1980-1990 m. Sample: cs, P39784, 1. Optical parameters: C, $144 \times 1042, \mathrm{O} 34 / 3, \times 50 \mathrm{bf}$ Repository: GSC 138117.

Fig. 7. Diphyes ficusoides, dorso-ventral view. Location: Bjarni O-82, 1905-1915 m. Sample: cs, P39718, 1. Optical parameters: C, $130 \times 1061, \mathrm{~N} 36 / 1-2, \times 50$ bf. Repository: GSC 138071.

Fig. 8. Diphyes ficusoides, dorso-ventral view. Location: Rut H-11, 3125-3135 m. Sample: cs, P39398, 1. Optical parameters: D, $164 \times 971, \mathrm{Q} 40 / 0, \times 40 \mathrm{pc}$. Repository: GSC 137965.

Fig. 9. Disphaerogena carposphaeropsis. Location: Annertuneq, 451 m, GGU405093. Sample: os, YD11738, 3. Optical parameters: A, $27.6 \times 96.7, \mathrm{U} 27 / 2, \times 40 \mathrm{bf}$. Repository: MGUH 31293.

Fig. 10. Cyclonephelium distinctum, dorsal view of dorsal surface. Location: Gilbert F-53, 3220-3230 m. Sample: cs, P39520, 1. Optical parameters: C, $28 \times 1026, \mathrm{~B} 32 / 3-4, \times 50$ bf. Repository: GSC 137990.
Fig. 11. Dinogymnium longicorne. Location: Skolp E-07, 1895 m. Sample: cs, JEH15633, 4. Optical parameters: A, $42.9 \times 110.5, \mathrm{E} 43 / 4, \times 60 \mathrm{bf}$. Repository: MGUH 31294.

Fig. 12. Diphyes colligerum, dorso-ventral view. Location: Gilbert F-53, 1990-2000 m. Sample: cs, P39479, 1. Optical parameters: C, $194 \times 1058$, T35/4, × 50 bf. Repository: GSC 137979.

Fig. 13. Eatonicysta furensis, dorsal view of dorsal surface. Location: North Leif I-05, 2070-2080 m. Sample: cs, YD17598, 3. Optical parameters: E, $19.3 \times 15.7, \mathrm{M} 17 / 0, \times 60 \mathrm{bf}$. Repository: GSC 138153.

Fig. 14. Eatonicysta ursulae, dorso-ventral view. Location: South Labrador N-79, 2220-2230 m. Sample: cs, P39792, 1. Optical parameters: C, $56 \times 1042$, E34/3, $\times 50$ bf. Repository: GSC 138119.

Fig. 15. Evittosphaerula? foraminosa sp. nov., apical view. Location: North Leif I-05, 2130-2140 m. Sample: cs, YD17600, 3. Optical parameters: E, $23.7 \times 10.0, \mathrm{~S} 22 / 1$, $\times 60 \mathrm{bf}$. Repository: GSC 138155.

Fig. 16. Evittosphaerula? foraminosa sp. nov., apical view of apical surface.

Location: North Leif I-05, 2190-2200 m. Sample: cs, YD17602, 3.

Optical parameters: E, $36.5 \times 26.0, \mathrm{~A} 35 / 0, \times 60$ bf.

Repository: GSC 138160.

Fig. 17. Evittosphaerula? foraminosa sp. nov., oblique apical view of epicyst.

Location: North Leif I-05, 2130-2140 m. Sample: cs, YD17600, 3.

Optical parameters: E, $32.8 \times 20.8, \mathrm{~F} 31 / 3, \times 60 \mathrm{bf}$.

Repository: GSC 138157.

Fig. 18. Evittosphaerula? foraminosa sp. nov., oblique antapical view. Location: North Leif I-05, 2130-2140 m. Sample: cs, YD17600, 3.

Optical parameters: E, $34.2 \times 5.7$, W32/2, × 60 bf.

Repository: GSC 138158.

Fig. 19. Evittosphaerula? foraminosa sp. nov., holotype, right lateral view focussed on right lateral surface.

Location: North Leif I-05, 2130-2140 m. Sample: cs, YD17600, 3.

Optical parameters: E, $44.9 \times 15.5$, M43/0, × 60 bf.

Repository: GSC 138159.

Fig. 20. Evittosphaerula? foraminosa sp. nov., holotype, right lateral view, focussed on left lateral surface.

Location: North Leif I-05, 2130-2140 m. Sample: cs, YD17600, 3.

Optical parameters: E, $44.9 \times 15.5, \mathrm{M} 43 / 0, \times 60 \mathrm{bf}$.

Repository: GSC 138159. 
Plate 6
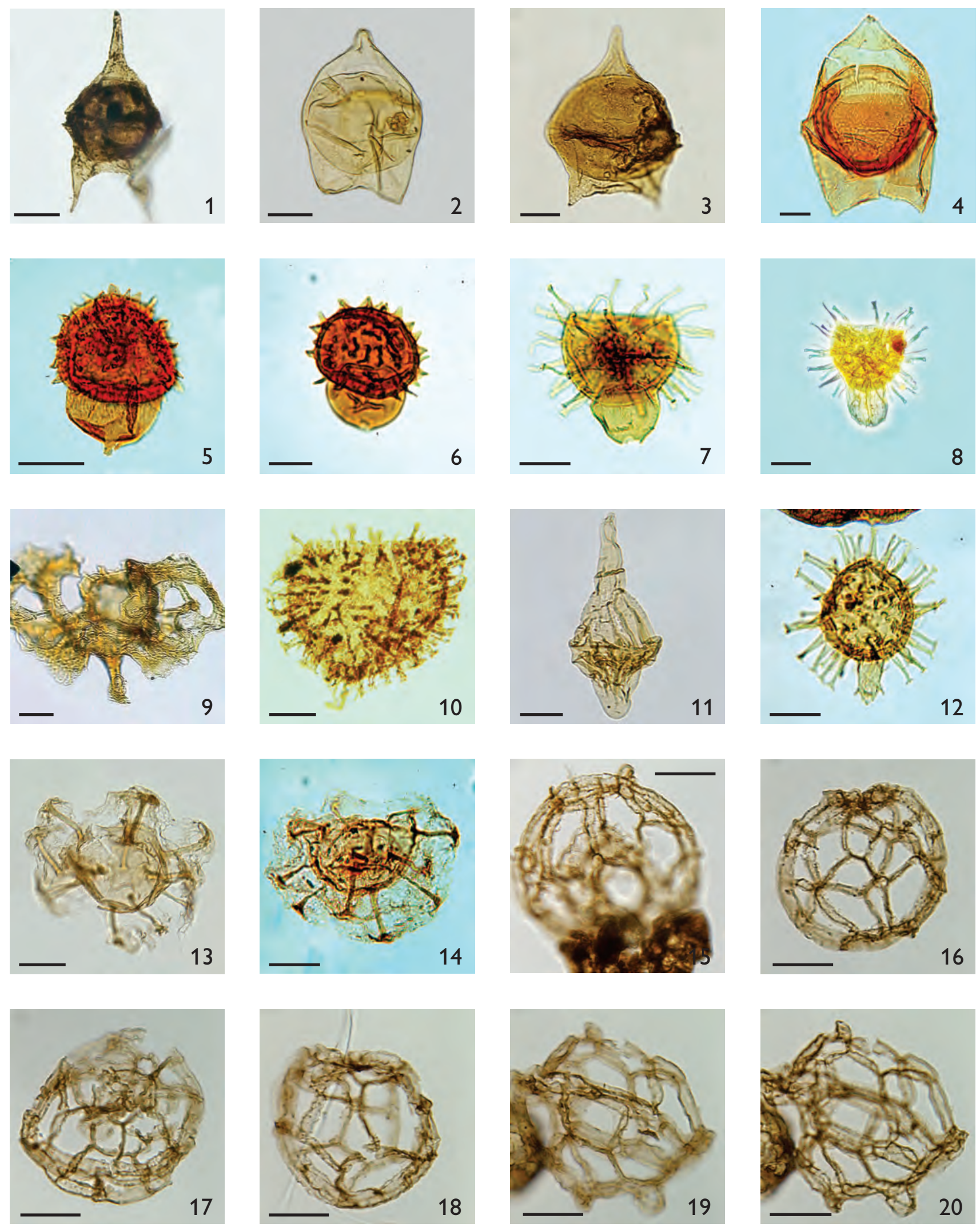


\section{Plate 7}

Fig. 1. Enneadocysta magna, ventral view.

Location: Rut H-11, 1205-1215 m. Sample: cs, P39334, 1.

Optical parameters: D, $100 \times 990, \mathrm{~J} 42 / 3, \times 40 \mathrm{pc}$.

Repository: GSC 137929.

Fig. 2. Enneadocysta magna, ventral view.

Location: Rut H-11, 1235-1245 m. Sample: cs, P39335, 1.

Optical parameters: D, $216 \times 859$, V28/3-4, $\times 40$ pc.

Repository: GSC 137933.

Fig. 3. Eocladopyxis peniculata.

Location: South Labrador N-79, 2310-2320 m. Sample: cs, P20171, 1.

Optical parameters: C, $190 \times 1100$, T41/0-3, × 50 bf.

Repository: GSC 137911.

Fig. 4. Fibrocysta bipolaris, right lateral view.

Location: Roberval K-92, 2390-2400 m. Sample: cs, P17704, 1.

Optical parameters: C, $33 \times 1090, \mathrm{C} 39 / 0, \times 50 \mathrm{bf}$.

Repository: GSC 137895.

Fig. 5. Ginginodinium? flexidentatum sp. nov., dorso-ventral view of ventral surface.

Location: North Leif I-05, 2010-2020 m. Sample: cs, YD17596, 3.

Optical parameters: E, $24.9 \times 21.8$, E23/3, × 60 bf.

Repository: GSC 138150.

Fig. 6. Ginginodinium? flexidentatum sp. nov., dorso-ventral view of dorsal surface.

Location: Ogmund E-72, 1340 m. Sample: cs, YD15727, 3.

Optical parameters: A, $43.4 \times 96.5, \mathrm{U} 44 / 1, \times 60 \mathrm{bf}$.

Repository: MGUH 31295.

Fig. 7. Ginginodinium? flexidentatum sp. nov., dorso-ventral view of ventral surface.

Location: Hekja O-71, 3090 m. Sample: cs, JEH16029, 2.

Optical parameters: E, $35.6 \times 20.8$, F34/0, × 60 bf.

Repository: MGUH 31296.

Fig. 8. Ginginodinium? flexidentatum sp. nov., dorso-ventral view. Location: Karlsefni A-13, 2807.24-2816.39 m. Sample: cs, P39619, 1.

Optical parameters: D, $146 \times 1060,049 / 0, \times 40$ pc.

Repository: GSC 138045.

Fig. 9. Ginginodinium? flexidentatum sp. nov., dorso-ventral view. Location: North Leif I-05, 2010-2020 m. Sample: cs, YD17596, 3.

Optical parameters: A, $22.5 \times 19.3, \mathrm{H} 20 / 0, \times 60$ bf.

Repository: GSC 138149.

Fig. 10. Ginginodinium? flexidentatum sp. nov., dorso-ventral view. Location: Rut H-11, 2915-2925 m. Sample: cs, P39391, 1.

Optical parameters: D, $140 \times 1029, \mathrm{O} 46 / 1, \times 40 \mathrm{pc}$.

Repository: GSC 137958.
Fig. 11. Ginginodinium? flexidentatum sp. nov., holotype, dorsoventral view.

Location: Bjarni O-82, 1815-1825 m. Sample: cs, P39715, 1.

Optical parameters: C, $36 \times 1028, \mathrm{C} 32 / 4, \times 50 \mathrm{bf}$.

Repository: GSC 138070.

Fig. 12. Gillinia hymenophora.

Location: Gilbert F-53, 3280-3290 m. Sample: cs, P39522, 1.

Optical parameters: C, $155 \times 1045, \mathrm{P} 34 / 3-4, \times 50$ bf.

Repository: GSC 137991.

Fig. 13. Habibacysta tectata, right lateral view, showing detached operculum.

Location: Karlsefni A-13, 667.52-676.66 m. Sample: cs, P39542, 1.

Optical parameters: D, $180 \times 979$, S41/1, $\times 40$ pc.

Repository: GSC 137995.

Fig. 14. Glaphyrocysta exuberans, dorso-ventral view. Location: North Leif I-05, 1530-1540 m. Sample: cs, YD15580, 2.

Optical parameters: A, $38.8 \times 23.5$, C37/4, × 60 bf.

Repository: MGUH 31297.

Fig. 15. Glaphyrocysta divaricata, dorso-ventral view.

Location: Karlsefni A-13, 3438.19-3447.33 m. Sample: cs, P39642, 1.

Optical parameters: D, $194 \times 1048, \mathrm{~T} 48 / 3, \times 40 \mathrm{pc}$.

Repository: GSC 138053.

Fig. 16. Glaphyrocysta divaricata, dorso-ventral view. Location: Karlsefni A-13, 3438.19-3447.33 m. Sample: cs, P39642, 1. Optical parameters: D, $188 \times 1032, \mathrm{~S} 46 / 3-4, \times 40 \mathrm{pc}$.

Repository: GSC 138052.

Fig. 17. Glaphyrocysta retiintexta, ventral view. Location: Karlsefni A-13, 4038.65-4047.79 m. Sample: cs, P39663, 1. Optical parameters: D, $220 \times 1066, \mathrm{~W} 49 / 2-4, \times 40 \mathrm{pc}$. Repository: GSC 138066.

Fig. 18. Histiocysta palla, ventral view. Location: Ogmund E-72, 1620 m. Sample: cs, YD15740, 4. Optical parameters: A, $37.0 \times 98.7, \mathrm{R} 37 / 4, \times 60$ bf. Repository: MGUH 31298.

Fig. 19. Histiocysta palla, oblique right lateral view, same specimen as fig. 18 .

Location: Ogmund E-72, 1620 m. Sample: cs, YD15740, 4.

Optical parameters: A, $37.0 \times 98.7, \mathrm{R} 37 / 4, \times 60 \mathrm{bf}$.

Repository: MGUH 31298.

Fig. 20. Histiocysta palla, dorsal surface.

Location: Bjarni O-82, 2300-2310 m. Sample: cs, P39731, 1.

Optical parameters: C, $140 \times 996, \mathrm{O} 29 / 0, \times 50$ bf.

Repository: GSC 138073. 
Plate 7
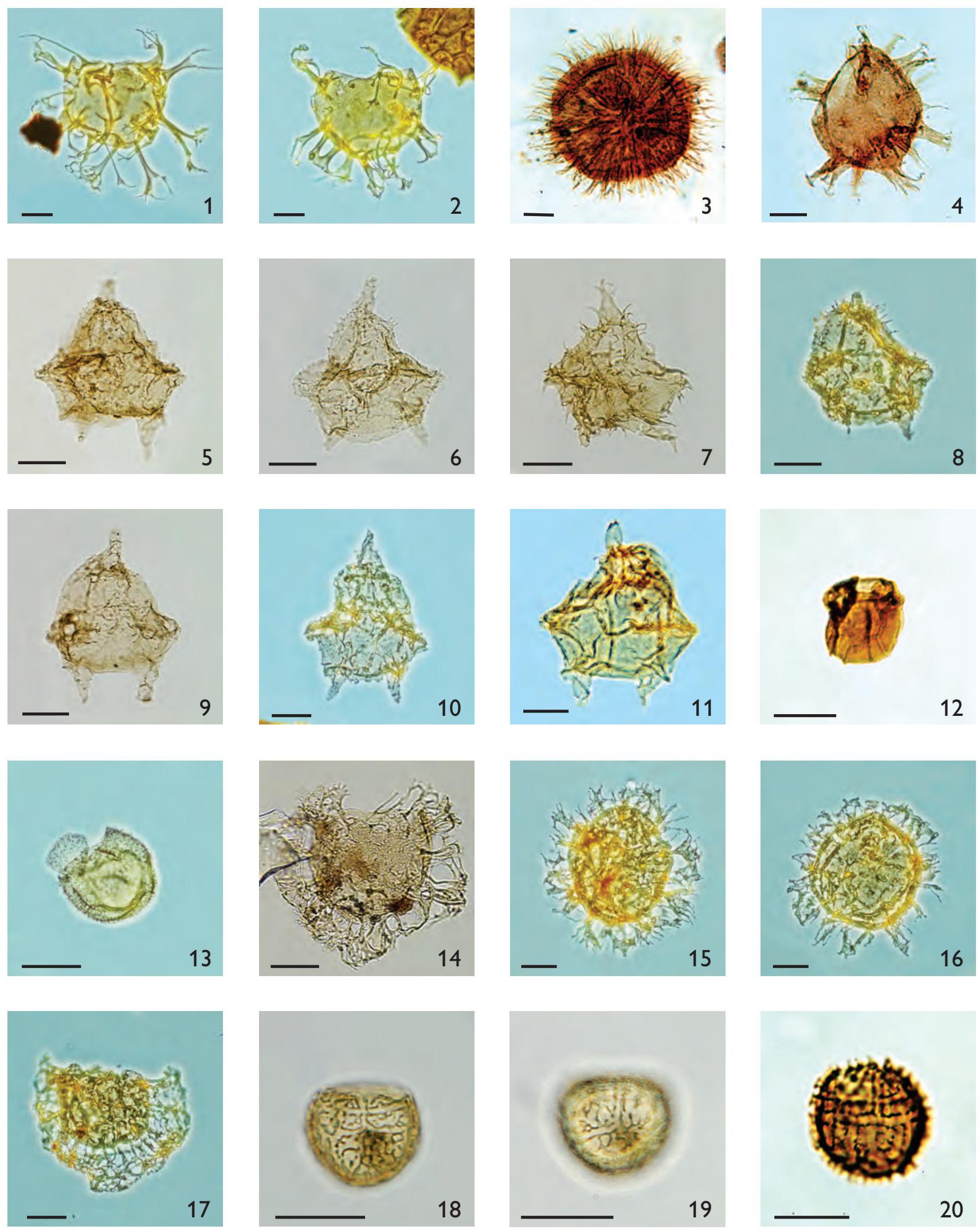


\section{Plate 8}

Fig. 1. Glaphyrocysta texta, oblique lateral view. Location: North Leif I-05, 2100-2110 m. Sample: cs, YD17599, 4. Optical parameters: E, $25.0 \times 16.6$, L23/2, $\times 60$ bf. Repository: MGUH 31299.

Fig. 2. Glaphyrocysta vicina, ventral view of ventral surface. Location: Ralegh N-18, 1725 m. Sample: cs, YD16224, 2.

Optical parameters: E, 45.9 × 7.7, T45/3, × $60 \mathrm{bf}$.

Repository: MGUH 31300.

Fig. 3. Heterosphaeridium bellii.

Location: Gilbert F-53, 3460-3470 m. Sample: cs, P39528, 1.

Optical parameters: C, $62 \times 1062, \mathrm{~F} 36 / 0, \times 50 \mathrm{bf}$.

Repository: GSC 137992.

Fig. 4. Heterosphaeridium bellii.

Location: North Leif I-05, 2670-2680 m. Sample: cs, YD17618, 3.

Optical parameters: E, $43.0 \times 7.1$, V41/2, × 60 bf.

Repository: GSC 138166.

Fig. 5. Homotryblium tenuispinosum, apical view, focussed on archaeopyle margin.

Location: Gilbert F-53, 1960-1970 m. Sample: cs, P39478, 1.

Optical parameters: C, $194 \times 983, \mathrm{~T} 28 / 3, \times 50 \mathrm{bf}$.

Repository: GSC 137978.

Fig. 6. Homotryblium tenuispinosum, apical view, same specimen as fig. 5, focussed on hypocyst.

Location: Gilbert F-53, 1960-1970 m. Sample: cs, P39478, 1.

Optical parameters: C, $194 \times 983, \mathrm{~T} 28 / 3, \times 50 \mathrm{bf}$.

Repository: GSC 137978.

Fig. 7. Homotryblium tenuispinosum, dorso-ventral view. Location: South Labrador N-79, 1920-1930 m. Sample: cs, P39782, 1. Optical parameters: C, $40 \times 1061, \mathrm{D} 35 / 1, \times 50$ bf.

Repository: GSC 138116.

Fig. 8. Heterosphaeridium difficile, dorso-ventral view. Location: South Labrador N-79, 3485-3495 m. Sample: cs, P20210, 1. Optical parameters: C, $168 \times 1128$, R43/1-2, × 50 bf.

Repository: GSC 137912.

Fig. 9. Homotryblium abbreviatum, dorsal view.

Location: Snorri J-90, 2249.45-2256.6 m. Sample: cs, P9747, 10. Optical parameters: C, $58 \times 1092$, F39/1-2, $\times 50$ bf.

Repository: GSC 138138.

Fig. 10. Homotryblium abbreviatum, apical view. Location: Snorri J-90, 2249.45-2266.6 m. Sample: cs, P9747, 10. Optical parameters: C, $50 \times 1000, \mathrm{E} 29 / 2, \times 50$ bf. Repository: GSC 138137.
Fig. 11. Hystrichokolpoma cinctum, dorsal surface. Location: Karlsefni A-13, 2642.65-2651.79 m. Sample: cs, P39613, 1. Optical parameters: D, $128 \times 920, \mathrm{M} 35 / 3, \times 40 \mathrm{pc}$. Repository: GSC 138041.

Fig. 12. Hapsocysta? benteae.

Location: North Leif I-05, 2310-2320 m. Sample: cs, YD17606, 4.

Optical parameters: E, $50.8 \times 19.9, \mathrm{G} 50 / 3, \times 60 \mathrm{bf}$.

Repository: MGUH 31301.

Fig. 13. Hystrichokolpoma globulus, left lateral view of left lateral surface.

Location: Snorri J-90, 2293,65 m. Sample: sw, P9370, 10.

Optical parameters: C, $181 \times 1017$, S31/0-4, × 50 bf.

Repository: GSC 138132.

Fig. 14. Hystrichokolpoma globulus, left lateral view, same specimen as fig. 13, focussed on right lateral surface.

Location: Snorri J-90, 2293,65 m. Sample: sw, P9370, 10.

Optical parameters: C, $181 \times 1017, \mathrm{~S} 31 / 0-4, \times 50 \mathrm{bf}$.

Repository: GSC 138132.

Fig. 15. Hystrichokolpoma globulus, lateral view. Location: Snorri J-90, 2441.48-2450.62 m. Sample: cs, P9751, 10.

Optical parameters: C, $102 \times 1010, \mathrm{~K} 30 / 4, \times 50$ bf.

Repository: GSC 138139.

Fig. 16. Heteraulacacysta porosa, antapical view of antapical surface. Location: Ralegh N-18, 1525 m. Sample: cs, YD16219, 4.

Optical parameters: E, $36.3 \times 20.5, \mathrm{G} 35 / 1, \times 60 \mathrm{bf}$.

Repository: CNSOPB.

Fig. 17. Hystrichosphaeridium quadratum sp. nov., holotype, dorsal surface.

Location: Gilbert F-53, 2770-2780 m. Sample: cs, P39505, 1.

Optical parameters: C, $113 \times 992, \mathrm{~L} / 29 / 3, \times 50$ bf.

Repository: GSC 137988.

Fig. 18. Hystrichosphaeridium quadratum sp. nov., holotype, focussed on ventral surface.

Location: Gilbert F-53, 2770-2780 m. Sample: cs, P39505, 1.

Optical parameters: C, $113 \times 992, \mathrm{~L} 29 / 3, \times 50 \mathrm{bf}$.

Repository: GSC 137988.

Fig. 19. Hystrichosphaeridium quadratum sp. nov., operculum, showing pre-apical process.

Location: Karlsefni A-13, 3904.54-3913.68 m. Sample: cs, P39658, 1.

Optical parameters: D, $125 \times 999, \mathrm{M} 43 / 0-3, \times 40 \mathrm{pc}$.

Repository: GSC 138057.

Fig. 20. Hystrichosphaeridium tubiferum, lateral view.

Location: Gjoa O-37, 2120 m. Sample: cs, YD16090, 4.

Optical parameters: E, $32.7 \times 22.0$, E31/0, × $60 \mathrm{bf}$.

Repository: CNSOPB. 
Plate 8
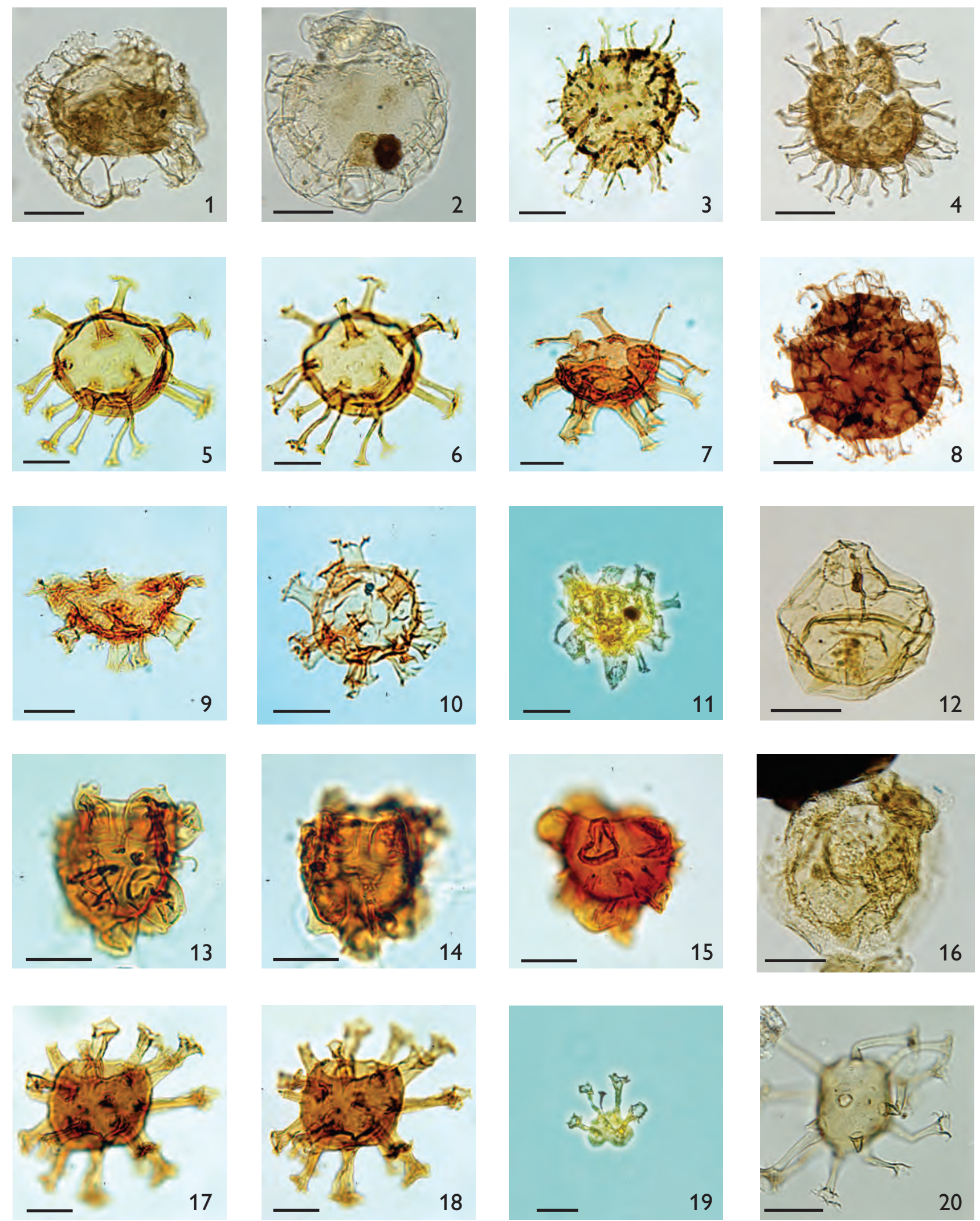


\section{Plate 9}

Fig. 1. Hystrichostrogylon digitus sp. nov., dorso-ventral view. Location: Karlsefni A-13, 2267.74-2276.88 m. Sample: cs, P39599, 1. Optical parameters: D, $200 \times 878, \mathrm{U} 30 / 0, \times 40 \mathrm{pc}$. Repository: GSC 138030.

Fig. 2. Hystrichostrogylon digitus sp. nov., dorso-ventral view. Location: Rut H-11, 2375-2385 m. Sample: cs, P39373, 1. Optical parameters: D, $167 \times 973$, Q40/3-4, × 40 pc. Repository: GSC 137950.

Fig. 3. Hystrichostrogylon digitus sp. nov., holotype, dorso-ventral view.

Location: Rut H-11, 2435-2445 m. Sample: cs, P39375, 1.

Optical parameters: D, $158 \times 1050$, Q48/1, $\times 40$ pc.

Repository: GSC 137952.

Fig. 4. Hystrichosphaeropsis perforata, dorso-ventral view. Location: Skolp E-07, 1250 m. Sample: cs, YD17614, 4. Optical parameters: A, $43.3 \times 101.4$, P44/1, × 60 bf. Repository: GSC 138164.

Fig. 5. Impletosphaeridium apodastum sp. nov., holotype. Location: Hekja O-71, 4565-4575 m. Sample: cs, P18737, 1. Optical parameters: C, $133 \times 1080, \mathrm{~N} 37 / 3, \times 50$ bf. Repository: GSC 137903.

Fig. 6. Impletosphaeridium apodastum sp. nov. Location: Karlsefni A-13, 3822.24-3831.38 m. Sample: cs, P39655, 1. Optical parameters: D, $201 \times 990, \mathrm{U} 42 / 1-3, \times 40 \mathrm{pc}$. Repository: GSC 138055.

Fig. 7. Impletosphaeridium apodastum sp. nov. Location: Karlsefni A-13, 3989.88-3999.02 m. Sample: cs, P39661, 1. Optical parameters: D, $193 \times 1070, \mathrm{~T} 50 / 0, \times 40 \mathrm{pc}$. Repository: GSC 138063.

Fig. 8. Impletosphaeridium apodastum sp. nov. Location: Karlsefni A-13, 3989.88-3999.02 m. Sample: cs, P39661, 1. Optical parameters: D, $173 \times 899, \mathrm{R} 32 / 0, \times 40 \mathrm{pc}$. Repository: GSC 138062.

Fig. 9. Impagidinium victorianum, ventral view of ventral surface. Location: Roberval K-92, 2270-2280 m. Sample: cs, P17700, 1. Optical parameters: C, $66 \times 1022, \mathrm{~F} 32 / 3, \times 50$ bf. Repository: GSC 137894 .

Fig. 10. Impagidinium victorianum, ventral view, same specimen as fig. 9, despite lower focus, ventral surface clear. Location: Roberval K-92, 2270-2280 m. Sample: cs, P17700, 1. Optical parameters: C, $66 \times 1022, \mathrm{~F} 32 / 3, \times 50 \mathrm{bf}$. Repository: GSC 137894.
Fig. 11. Impagidinium victorianum, ventral view, same specimen as fig. 9, focussed on periphery.

Location: Roberval K-92, 2270-2280 m. Sample: cs, P17700, 1.

Optical parameters: C, $66 \times 1022, \mathrm{~F} 32 / 3, \times 50$ bf.

Repository: GSC 137894.

Fig. 12. Hystrichosphaeropsis quasicribrata, dorso-ventral view. Location: North Leif I-05, 2550-2560 m. Sample: cs, YD17614, 4. Optical parameters: E, $43.9 \times 15.8$, M43/2, × 60 bf. Repository: GSC 138165.

Fig. 13. Impagidinium victorianum, dorsal view of ventral surface. Location: Skolp E-07, 1175 m. Sample: cs, YD15587, 3.

Optical parameters: A, $34.2 \times 99.0$, S435/1, × 60 bf.

Repository: MGUH 31302.

Fig. 14. Impagidinium victorianum, dorsal view of dorsal surface, same specimen as fig. 13.

Location: Skolp E-07, 1175 m. Sample: cs, YD15587, 3.

Optical parameters: A, $34.2 \times 99.0, S 435 / 1, \times 60$ bf.

Repository: MGUH 31302.

Fig. 15. Isabelidinium cretaceum, dorso-ventral view. Location: North Leif I-05, 2550-2560 m. Sample: cs, YD17614, 2. Optical parameters: E, $17.4 \times 20.3, \mathrm{G} 15 / 0, \times 60$ bf. Repository: MGUH 31303.

Fig. 16. Isabelidinium cretaceum, dorso-ventral view. Location: Roberval K-92, 3060-3070 m. Sample: cs, P17726, 1. Optical parameters: C, $157 \times 1085, \mathrm{Q} 38 / 2, \times 50$ bf. Repository: GSC 137899.

Fig. 17. Isabelidinium microarmum, dorsal view of dorsal surface. Location: Skolp E-07, 2285 m. Sample: cs, YD15659, 2.

Optical parameters: A, $24.4 \times 93.5, \mathrm{X} 24 / 2, \times 60 \mathrm{bf}$.

Repository: MGUH 31304.

Fig. 18. Kleithriasphaeridium mantellii, right lateral view. Location: Maude Bight, Bylot Island, section 3 (V002181), 1 m above base (sample PB-57). Sample: os, P5189-46, H.

Optical parameters: C, $161 \times 932$, L54/1-3, × 50 bf.

Repository: GSC 138131.

Fig. 19. Laciniadinium arcticum, ventral view of ventral surface. Location: Ogmund E-72, 1530 m (reworked specimen). Sample: cs, YD15734, 3.

Optical parameters: A, $23.6 \times 98.0$, S23/4, × 60 bf. Repository: MGUH 31305.

Fig. 20. Laciniadinium arcticum, dorsal view of ventral surface. Location: Skolp E-07, 1940 m. Sample: cs, JEH15635, 3.

Optical parameters: A, $19.5 \times 104.7, \mathrm{~L} 19 / 3, \times 60 \mathrm{bf}$. Repository: MGUH 31306. 


\section{Plate 9}
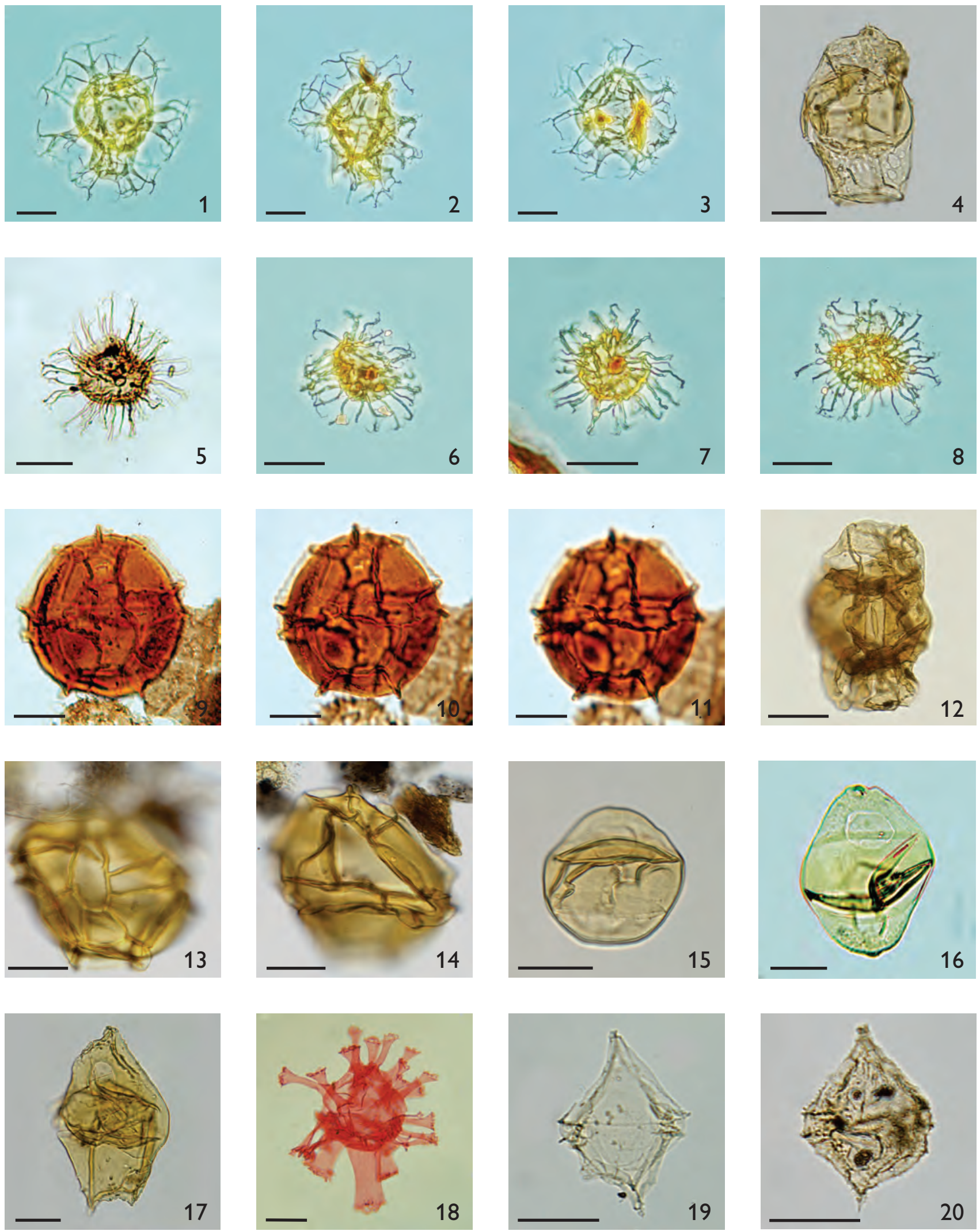


\section{Plate 10}

Fig. 1. Lingulodinium funginum.

Location: Karlsefni A-13, 2670.08-2679.22 m. Sample: cs, P39614, 1.

Optical parameters: D, $145 \times 1047, \mathrm{O} 48 / 3, \times 40 \mathrm{pc}$.

Repository: GSC 138042.

Fig. 2. Lingulodinium funginum.

Location: Rut H-11, 3035-3045 m. Sample: cs, P39395, 1

Optical parameters: D, $73 \times 929, \mathrm{G} 36 / 1, \times 40 \mathrm{pc}$.

Repository: GSC 137961.

Fig. 3. Lingulodinium machaerophorum.

Location: Rut H-11, 2585-2595 m. Sample: cs, P39380, 1.

Optical parameters: D, $105 \times 900, \mathrm{~K} 32 / 2, \times 40 \mathrm{pc}$.

Repository: GSC 137954.

Fig. 4. Lingulodinium machaerophorum, dorso-ventral view showing attached operculum.

Location: Gjoa O-37, 1620 m. Sample: cs, YD16074, 2.

Optical parameters: E, $18.0 \times 19.6, \mathrm{H} 16 / 1, \times 60 \mathrm{bf}$.

Repository: MGUH 31307.

Fig. 5. Nyktericysta davisii, dorso-ventral view.

Location: North Leif I-05, 3180-3190 m. Sample: cs, YD17635, 4.

Optical parameters: E, $37.5 \times 4.7, \mathrm{X} 36 / 0, \times 40 \mathrm{bf}$.

Repository: GSC 138169.

Fig. 6. Nyktericysta davisii, dorso-ventral view.

Location: North Leif I-05, 3180-3190 m. Sample: cs, YD17635, 4.

Optical parameters: E, $20.9 \times 12.4, \mathrm{P} 19 / 3, \times 60 \mathrm{bf}$.

Repository: GSC 138168.

Fig. 7. Nyktericysta dictyophora, dorso-ventral view.

Location: Ogmund E-72, 1995 m. Sample: cs, YD15765, 3.

Optical parameters: A, $37.3 \times 94.1$, W38/3, × 60 bf.

Repository: MGUH 31308.

Fig. 8. Nyktericysta dictyophora, dorso-ventral view.

Location: Ogmund E-72, 1965 m. Sample: cs, YD15763, 3.

Optical parameters: A, $23.8 \times 100.8, \mathrm{P} 23 / 4, \times 60$ bf.

Repository: MGUH 31309.

Fig. 9. Lentinia serrata, dorsal view of dorsal surface.

Location: South Labrador N-79, 2700-2710 m. Sample: cs, P39807, 1.

Optical parameters: C, $65 \times 1027, \mathrm{~F} 32 / 0-4, \times 50$ bf.

Repository: GSC 138122 .

Fig. 10. Palaeocystodinium golzowense, dorso-ventral view. Location: Rut H-11, 755-765 m. Sample: cs, P39319, 1.

Optical parameters: D, $61 \times 1040, \mathrm{E} 47 / 3, \times 40 \mathrm{pc}$.

Repository: GSC 137920.
Fig. 11. Nyktericysta tripenta, dorso-ventral view; endophragm visible apically.

Location: Ogmund E-72, 2550 m. Sample: cs, JEH15891, 3.

Optical parameters: A, $47.9 \times 105.8, \mathrm{~K} 49 / 3, \times 60$ bf.

Repository: MGUH 31310.

Fig. 12. Nyktericysta tripenta, dorso-ventral view, same specimen as fig. 11 .

Location: Ogmund E-72, 2550 m. Sample: cs, JEH15891, 3.

Optical parameters: A, $47.9 \times 105.8, \mathrm{~K} 49 / 3, \times 60$ bf.

Repository: MGUH 31310.

Fig. 13. Odontochitina porifera, dorsal view. Location: Skolp E-07, 1895 m. Sample: cs, JEH15633, 4.

Optical parameters: A, $33.2 \times 107.7, \mathrm{H} 33 / 4, \times 60 \mathrm{bf}$.

Repository: MGUH 31311.

Fig. 14. Odontochitina ancala, dorsal view.

Location: North Leif I-05, 2790-2800 m. Sample: cs, YD17622, 3.

Optical parameters: E, $20.1 \times 18.5, \mathrm{~J} 18 / 1$, × $40 \mathrm{bf}$.

Repository: MGUH 31312.

Fig. 15. Odontochitina costata, dorsal view.

Location: Skolp E-07, 2345 m. Sample: cs, YD15663, 2.

Optical parameters: A, $40.3 \times 111.8, \mathrm{D} 40 / 2, \times 60 \mathrm{bf}$.

Repository: MGUH 31313.

Fig. 16. Licracysta corymbus, dorsal surface.

Location: Rut H-11, 1205-1215 m. Sample: cs, P39334, 1.

Optical parameters: D, $150 \times 974, \mathrm{P} 40 / 1-2, \times 40 \mathrm{pc}$.

Repository: GSC 137931.

Fig. 17. Oligosphaeridium albertense.

Location: Rut H-11, 1775-1785 m. Sample: cs, P39353, 1.

Optical parameters: D, $85 \times 866, \mathrm{H} 29 / 0, \times 40 \mathrm{pc}$.

Repository: GSC 137939.

Fig. 18. Oligosphaeridium pulcherrimum, dorso-ventral view. Location: Gilbert F-53, 2705-2715 m. Sample: cs, P39503, 1.

Optical parameters: C, $24 \times 1012, \mathrm{Y} 31 / 3, \times 50 \mathrm{bf}$.

Repository: GSC 137986.

Fig. 19. Oligosphaeridium pulcherrimum.

Location: Rut H-11, 1745-1755 m. Sample: cs, P39352, 1.

Optical parameters: D, $168 \times 880, \mathrm{Q} 30 / 4, \times 40 \mathrm{pc}$.

Repository: GSC 137938.

Fig. 20. Oligosphaeridium totum.

Location: Rut H-11, 2225-2235 m. Sample: cs, P39368, 1.

Optical parameters: D, $154 \times 1052, \mathrm{P} 48 / 0, \times 40 \mathrm{pc}$.

Repository: GSC 137944. 
Plate 10
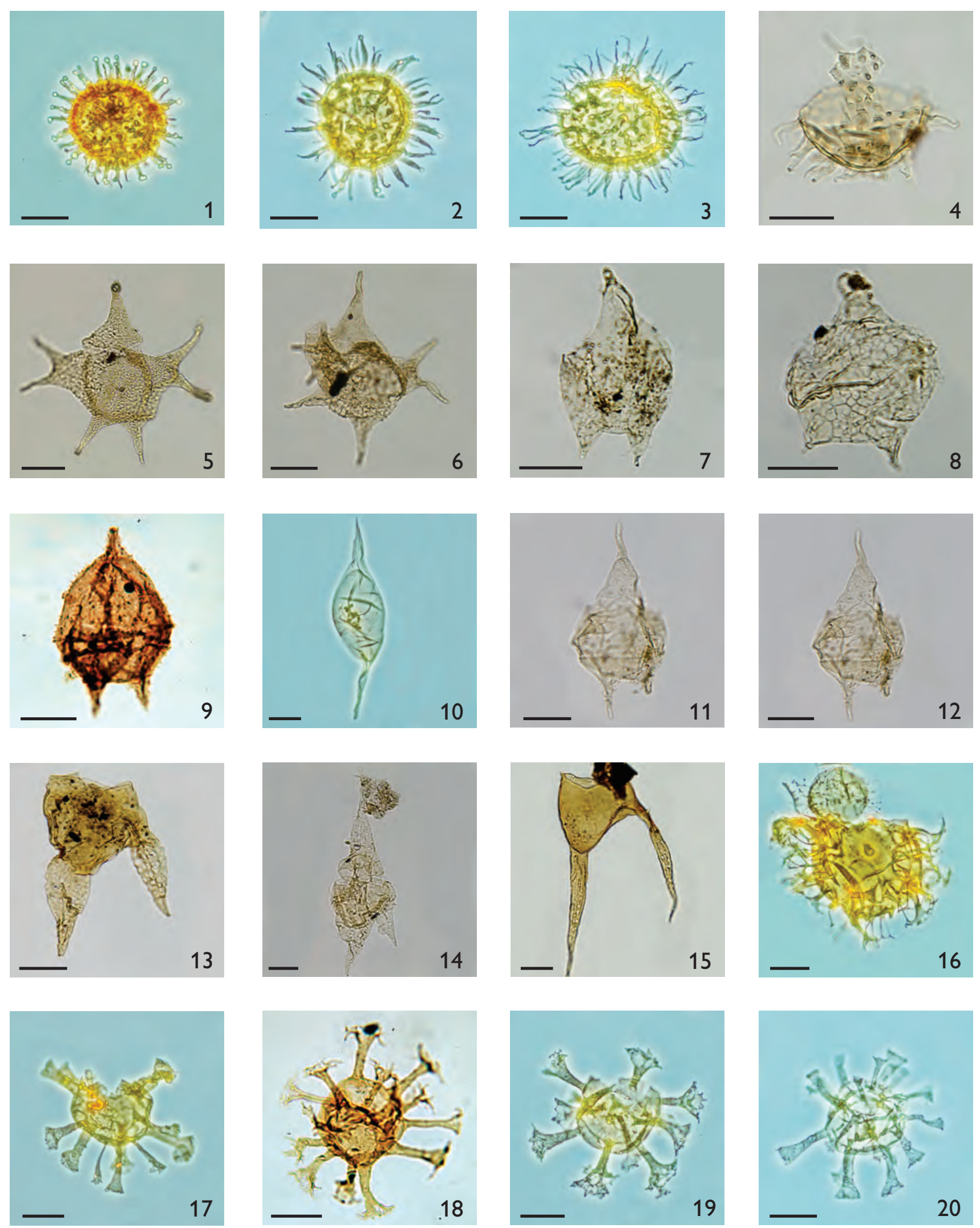


\section{Plate 11}

Fig. 1. Palaeocystodinium bulliforme, right lateral view. Location: Gilbert F-53, 2470-2480 m. Sample: cs, P19228, 1. Optical parameters: C, $163 \times 1082$, Q28/3, × 50 bf. Repository: GSC 137904.

Fig. 2. Palaeocystodinium bulliforme.

Location: Ogmund E-72, 1545 m. Sample: cs, YD15735, 4.

Optical parameters: A, $30.6 \times 110.6, \mathrm{E} 31 / 3, \times 40 \mathrm{bf}$.

Repository: CNLOPB.

Fig. 3. Palaeocystodinium teespinosum, left lateral view. Location: Karlsefni A-13, 969.28-978.42 m. Sample: cs, P39553, 1. Optical parameters: D, $201 \times 922, \mathrm{U} 35 / 1, \times 40$ pc. Repository: GSC 138007.

Fig. 4. Palaeohystrichophora infusorioides, dorsal view. Location: North Leif I-05, 3000-3010 m. Sample: cs, YD17629, 3. Optical parameters: E, $25.0 \times 20.2$, G23/0, $\times 60 \mathrm{bf}$. Repository: MGUH 31314.

Fig. 5. Operculodinium centrocarpum.

Location: Karlsefni A-13, 694.95-704.10 m. Sample: cs, P39543, 1. Optical parameters: D, $143 \times 996, \mathrm{O} 42 / 0, \times 40$ pc. Repository: GSC 137996.

Fig. 6. Operculodinium centrocarpum, operculum. Location: Karlsefni A-13, 722.38-731.53 m. Sample: cs, P39544, 1. Optical parameters: D, $169 \times 934, \mathrm{R} 36 / 1-2, \times 40 \mathrm{pc}$. Repository: GSC 137998.

Fig. 7. Palaeoperidinium pyrophorum, dorsal surface. Location: Gilbert F-53, 2680-2690 m. Sample: cs, P39502, 1. Optical parameters: C, $68 \times 1101, \mathrm{~F} 40 / 3-\mathrm{G} 40 / 1, \times 50$ bf. Repository: GSC 137985.

Fig. 8. Palaeoperidinium pyrophorum, ventral view. Location: Roberval K-92, 3070-3080 m. Sample: cs, P2008175, 1. Optical parameters: C, $200 \times 982, \mathrm{U} 27 / 4-\mathrm{U} 28 / 3, \times 50 \mathrm{bf}$. Repository: GSC 137907.

Fig. 9. Palynodinium grallator, apical view. Location: Roberval K-92, 2840-2850 m. Sample: cs, P17719, 1. Optical parameters: C, $30 \times 1087$, C38/2-C39/1, × 50 bf. Repository: GSC 137898

Fig. 10. Palynodinium grallator, dorsal view. Location: North Leif I-05, 2520-2530 m. Sample: cs, YD17613, 4. Optical parameters: E, $44.0 \times 16.5, \mathrm{~L} 46 / 3, \times 60 \mathrm{bf}$. Repository: GSC 138163.
Fig. 11. Petalodinium condylos, ventral view of dorsal surface. Location: Roberval K-92, 2420-2430 m. Sample: cs, P17705, 1.

Optical parameters: C, $110 \times 1018$, Q31/2-4, × 50 bf. Repository: GSC 137896.

Fig. 12. Petalodinium condylos, ventral view of dorsal surface. Location: Roberval K-92, 2240-2250 m. Sample: cs, P17699, 1. Optical parameters: C, $175 \times 1052$, S35/1, × 50 bf. Repository: GSC 137892.

Fig. 13. Phthanoperidinium coreoides, dorsal surface. Location: Rut H-11, 1145-1155 m. Sample: cs, P39332, 1. Optical parameters: D, $126 \times 991, \mathrm{M} 42 / 0, \times 40 \mathrm{pc}$. Repository: GSC 137928.

Fig. 14. Phthanoperidinium coreoides, dorsal surface. Location: North Leif I-05, 720-730 m. Sample: cs, YD17553, 2. Optical parameters: E, $46.7 \times 11.2$, Q46/1, × 60 bf. Repository: MGUH 31315.

Fig. 15. Phthanoperidinium levimurum. Location: Karlsefni A-13, 3273.59-3282.74 m. Sample: cs, P39636, 1. Optical parameters: D, $100 \times 1064, \mathrm{~J} 50 / 3, \times 40 \mathrm{pc}$. Repository: GSC 138050.

Fig. 16. Phthanoperidinium multispinum, dorsal surface. Location: South Labrador N-79, 1260-1270 m. Sample: cs, P39762, 1. Optical parameters: C, $87 \times 1017, \mathrm{~J} 31 / 2, \times 50$ bf. Repository: GSC 138110.

Fig. 17. Phthanoperidinium multispinum, ventral surface. Location: Karlsefni A-13, 1956.84-1965.98 m. Sample: cs, P39588, 1. Optical parameters: D, $194 \times 1025, \mathrm{~T} 45 / 4, \times 40 \mathrm{pc}$. Repository: GSC 138020.

Fig. 18. Phthanoperidinium regale, ventral view of ventral surface. Location: Hellefisk-1, 1289 m. Sample: cs, 02B2097-4, 4.

Optical parameters: A, $48.5 \times 105.9, \mathrm{~K} 49 / 4, \times 40$ bf. Repository: MGUH 26504.

Fig. 19. Phthanoperidinium regale, ventral view of dorsal surface, same specimen as fig. 18.

Location: Hellefisk-1, 1289 m. Sample: cs, 02B2097-4, 4.

Optical parameters: A, $48.5 \times 105.9, \mathrm{~K} 49 / 4, \times 60$ bf. Repository: MGUH 26504.

Fig. 20. Phthanoperidinium stockmansii, ventral view of ventral surface.

Location: South Labrador N-79, 1230-1240 m. Sample: cs, P39761, 1.

Optical parameters: C, $67 \times 1021, \mathrm{~F} 32 / 3, \times 50$ bf.

Repository: GSC 138109. 
Plate 11
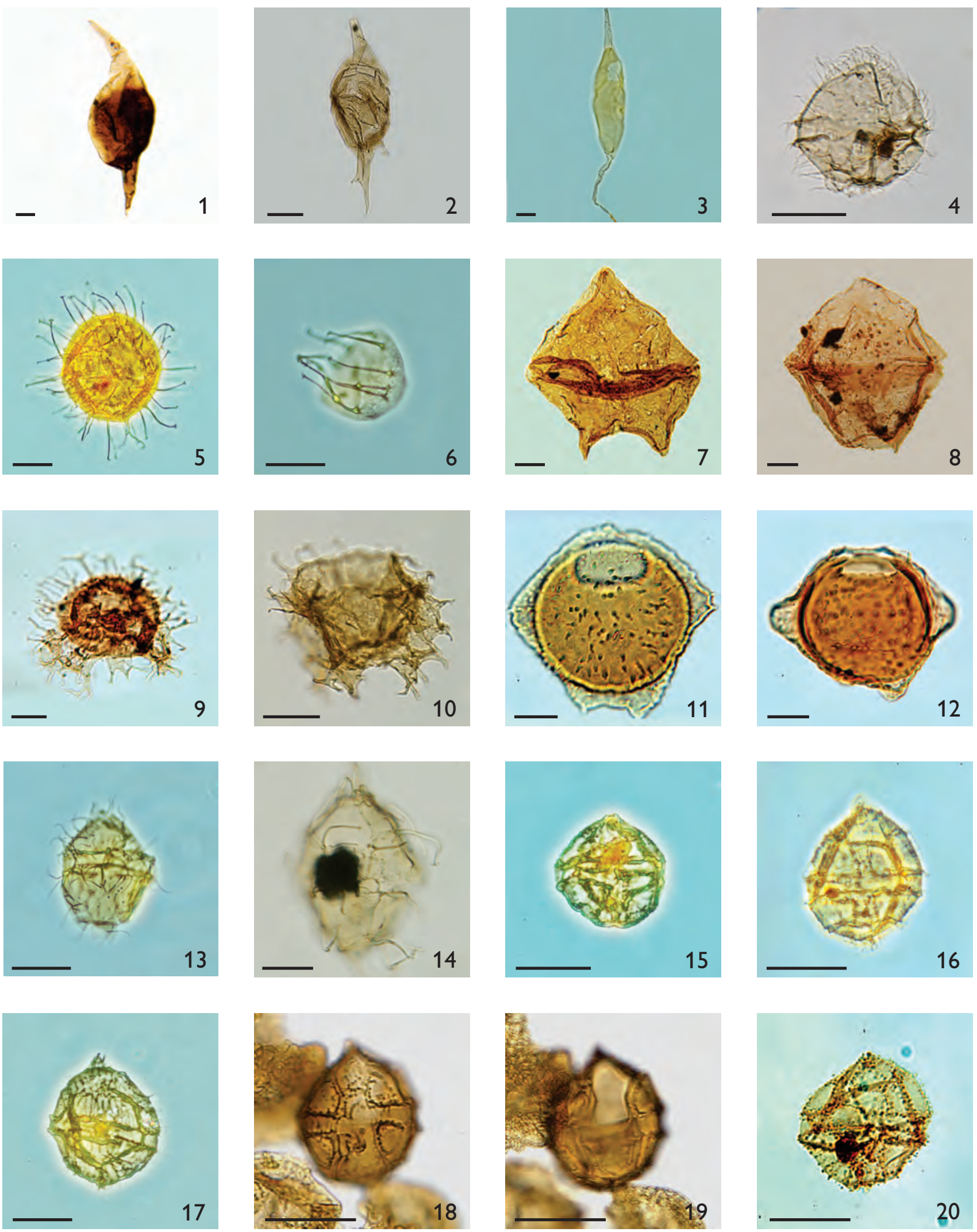


\section{Plate 12}

Fig. 1. Phelodinium kozlowskii, dorsal surface. Location: Gilbert F-53, 2740-2750 m. Sample: cs, P39504, 1. Optical parameters: C, $203 \times 1020$, U31/4-U32/3, × 50 bf. Repository: GSC 137987.

Fig. 2. Phelodinium kozlowskii, oblique left lateral view. Location: Bjarni O-82, 2175-2185 m. Sample: cs, P39727, 1 Optical parameters: C, $139 \times 993, \mathrm{O} 29 / 1, \times 50$ bf. Repository: GSC 138072.

Fig. 3. Phelodinium kozlowskii, dorsal view showing dorsal and ventral surfaces.

Location: South Labrador N-79, 3030-3040 m. Sample: cs, P39818, 1. Optical parameters: C, $218 \times 1000, \mathrm{~N} 29 / 2, \times 50 \mathrm{bf}$.

Repository: GSC 138123

Fig. 4. Pseudoceratium sp., ventral view. Location: Roberval K-92, 3070-3080 m. Sample: cs, P2008175, 1. Optical parameters: C, $210 \times 993$, V29/0-3, × 40 pc. Repository: GSC 137908

Fig. 5. Piladinium columna, ventral view of dorsal surface. Location: Bjarni O-82, 1785-1795 m. Sample: cs, P39714, 1. Optical parameters: C, $221 \times 1054, \mathrm{~W} 32 / 3-4, \times 50$ bf. Repository: GSC 138069.

Fig. 6. Piladinium columna, dorsal view of dorsal surface. Location: Roberval K-92, 2270-2280 m. Sample: cs, P17700, 1. Optical parameters: C, $200 \times 1014$, U31/0, × 50 bf. Repository: GSC 137893.

Fig. 7. Piladinium edwardsii, dorsal view of dorsal surface. Location: Ogmund E-72, 1305 m. Sample: sw, JEH15551, 4. Optical parameters: A, $27.3 \times 98.6, \mathrm{~T} 27 / 1, \times 60 \mathrm{bf}$. Repository: MGUH 31316.

Fig. 8. Piladinium edwardsii, dorsal view of dorsal surface Location: North Leif I-05, 2010-2020 m. Sample: cs, YD17596, 3. Optical parameters: E, $21.0 \times 10.6$, R18/1, × 60 bf. Repository: MGUH 31317.

Fig. 9. Raphidodinium fucatum, dorsal surface. Location: Bjarni O-82, 2415-2425 m. Sample: cs, P39735, 1. Optical parameters: C, $228 \times 1077, \mathrm{X} 32 / 0-2, \times 50$ bf. Repository: GSC 138074.

Fig. 10. Raphidodinium fucatum. Location: Skolp E-07, 1475 m. Sample: cs, YD15606, 3. Optical parameters: A, $43.7 \times 94.7, \mathrm{~W} 44 / 1, \times 60 \mathrm{bf}$. Repository: MGUH 31318.
Fig. 11. Reticulatosphaera actinocoronata.

Location: Karlsefni A-13, 722.38-731.53 m. Sample: cs, P39544, 1. Optical parameters: D, $146 \times 930,036 / 3, \times 40 \mathrm{pc}$. Repository: GSC 137997.

Fig. 12. Reticulatosphaera actinocoronata. Location: Rut H-11, 755-765 m. Sample: cs, P39319, 1.

Optical parameters: D, $89 \times 1006, \mathrm{H} 43 / 4, \times 40 \mathrm{pc}$. Repository: GSC 137921.

Fig. 13. Rhombodinium draco, ventral view of dorsal surface. Location: Snorri J-90, 1673.37-1682.52 m. Sample: cs, P9729, 10. Optical parameters: C, $93 \times 1007, \mathrm{~J} 29 / 0, \times 40$ pc. Repository: GSC 138134.

Fig. 14. Rhombodinium draco, ventral view of ventral surface. Location: Bjarni O-82, 615-625 m. Sample: cs, P39675, 1.

Optical parameters: C, $148 \times 1035, \mathrm{P} 33 / 0, \times 40 \mathrm{bf}$. Repository: GSC 138067.

Fig. 15. Scalenodinium scalenum sp. nov., holotype, left lateral view.

Location: Gilbert F-53, 2135-2145 m. Sample: cs, P38484, 1.

Optical parameters: C, $193 \times 1065$, T37/4, × 50 bf.

Repository: GSC 137916.

Fig. 16. Scalenodinium scalenum sp. nov., left lateral view. Location: Gilbert F-53, 2135-2145 m. Sample: cs, P39484, 1. Optical parameters: C, $48 \times 1020$, D32/3-D31/4, $\times 50$ bf. Repository: GSC 137982.

Fig. 17. Scalenodinium scalenum sp. nov.

Location: Ogmund E-72, 1391 m. Sample: sw, YD15553, 2.

Optical parameters: A, $26.8 \times 107.0, \mathrm{~J} 26 / 4, \times 60 \mathrm{bf}$.

Repository: MGUH 31319.

Fig. 18. Scalenodinium scalenum sp. nov.

Location: Ralegh N-18, 3005 m. Sample: cs, YD16263, 4.

Optical parameters: E, $41.6 \times 11.1$, Q40/4, × 60 bf.

Repository: MGUH 31320.

Fig. 19. Scalenodinium scalenum sp. nov., oblique left lateral view. Location: Ralegh N-18, 3045 m. Sample: cs, YD16264, 3.

Optical parameters: E, $28.9 \times 19.9$, G27/0, $\times 60$ bf. Repository: MGUH 31321.

Fig. 20. Scalenodinium scalenum sp. nov.

Location: North Leif I-05, 2130-2140 m. Sample: cs, YD17600, 3.

Optical parameters: E, $29.4 \times 7.6, \mathrm{U} 27 / 2, \times 60 \mathrm{bf}$.

Repository: GSC 138156. 


\section{Plate 12}
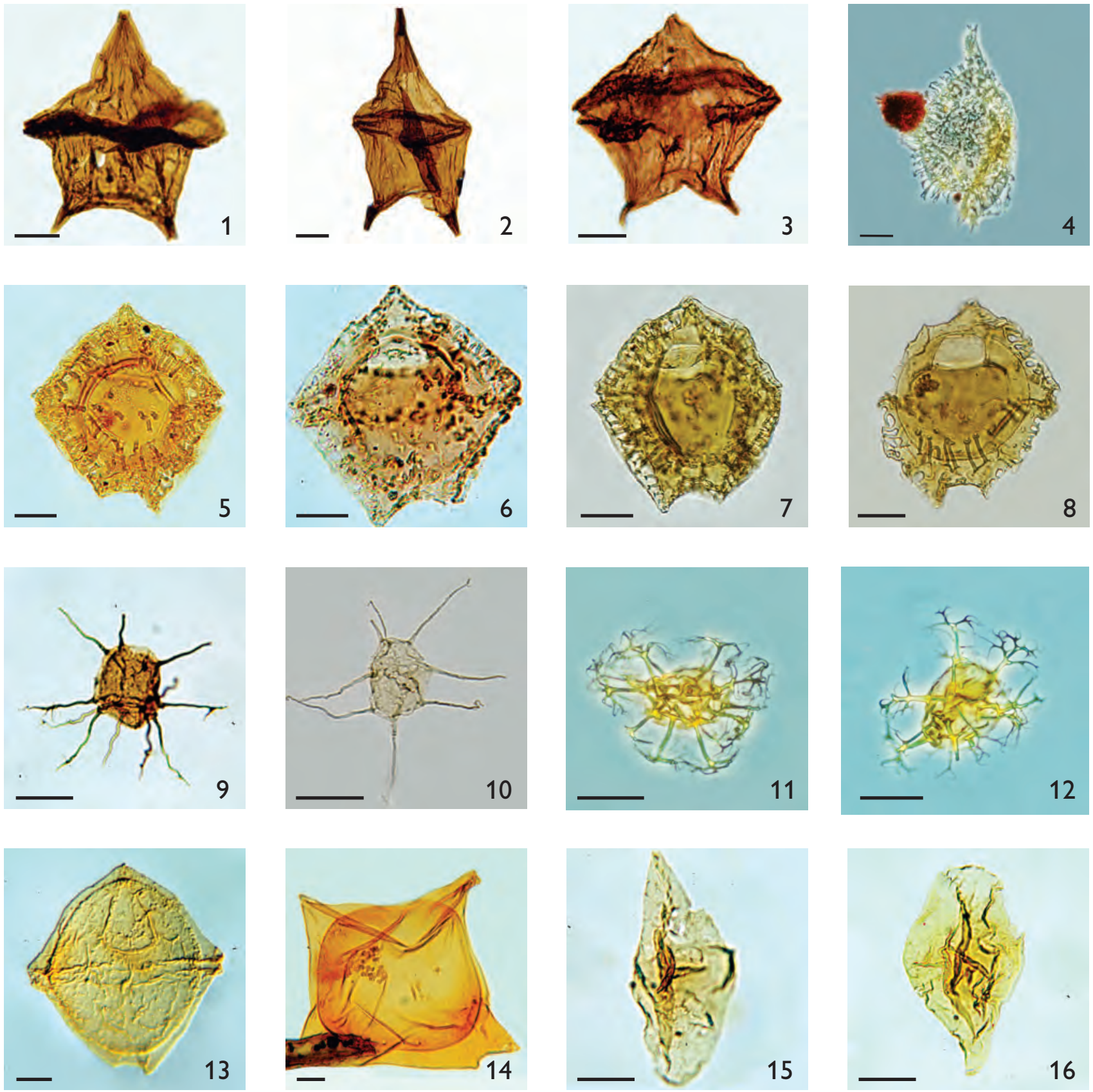

15
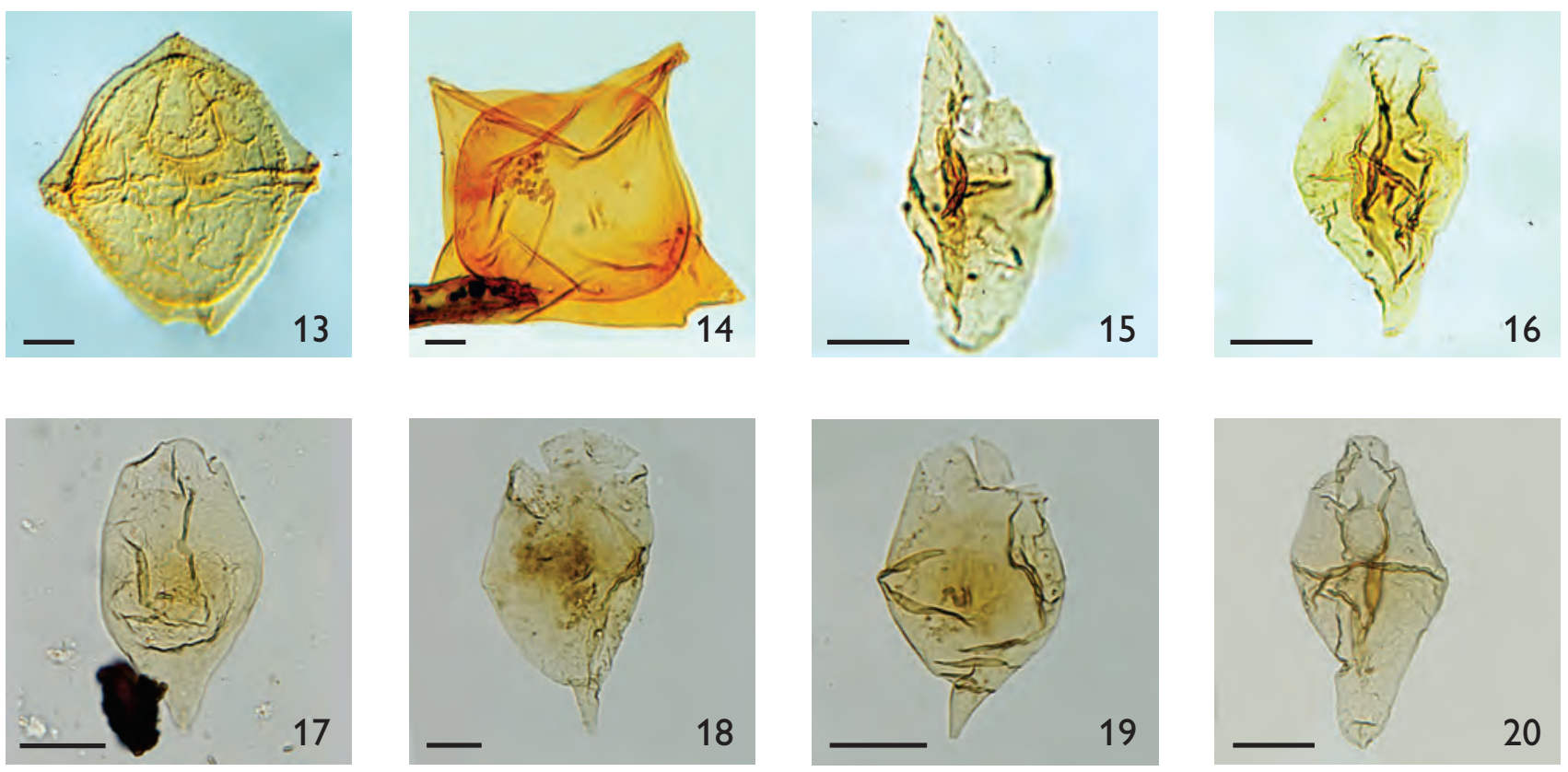


\section{Plate 13}

Fig. 1. Rottnestia borussica, right lateral view.

Location: South Labrador N-79, 2430-2440 m. Sample: cs, P39799, 1. Optical parameters: C, $105 \times 990, \mathrm{~K} 28 / 4, \times 50$ bf. Repository: GSC 138121.

Fig. 2. Schematophora speciosa, dorsal surface. Location: South Labrador N-79, 1290-1300 m. Sample: cs, P39763, 1. Optical parameters: C, $126 \times 982$, N28/1-N27/2, × 50 bf. Repository: GSC 138111.

Fig. 3. Senegalinium iterlaaense, dorsal surface. Location: Gjoa O-37, 3560 m. Sample: cs, YD16131, 5. Optical parameters: E, $46.4 \times 11.6, \mathrm{Q} 45 / 4, \times 60 \mathrm{bf}$. Repository: GSC 138146.

Fig. 4. Senegalinium iterlaaense, ventral view of dorsal surface. Location: Gjoa O-37, 3610 m. Sample: cs, YD16132, 3.

Optical parameters: E, $37.1 \times 3.9, \mathrm{X} 36 / 3$, $\times 60 \mathrm{bf}$. Repository: MGUH 31322.

Fig. 5. Senoniasphaera inornata, dorsal view. Location: North Leif I-05, 2490-2500 m. Sample: cs, YD17612, 3. Optical parameters: E, $41.2 \times 8.3$, T40/2, × 60 bf. Repository: GSC 138162.

Fig. 6. Senoniasphaera microreticulata, dorsal view. Location: North Leif I-05, 2820-2830 m. Sample: cs, YD17623, 2. Optical parameters: E, $41.5 \times 9.2$, S40/2, $\times 60$ bf. Repository: MGUH 31323.

Fig. 7. Senoniasphaera rotundata, dorsal view of dorsal surface. Location: South Labrador N-79, 3480-3490 m. Sample: cs, P39833, 1. Optical parameters: C, $114 \times 1037, \mathrm{~L} 33 / 4, \times 50 \mathrm{bf}$. Repository: GSC 138126.

Fig. 8. Sophismatia tenuivirgula, dorso-ventral view. Location: North Leif I-05, 1560-1570 m. Sample: cs, YD17581, 2. Optical parameters: E, $49.0 \times 14.2, \mathrm{~N} 48 / 2, \times 60$ bf. Repository: MGUH 31324.

Fig. 9. Simplicidinium insolitum. Location: Rut H-11, 1205-1215 m. Sample: cs, P39334, 1. Optical parameters: D, $152 \times 871, \mathrm{P} 29 / 2, \times 40 \mathrm{pc}$. Repository: GSC 137932.

Fig. 10. Simplicidinium insolitum. Location: Karlsefni A-13, 804.68-813.83 m. Sample: cs, P39547, 1. Optical parameters: D, $162 \times 1052, \mathrm{Q} 48 / 0, \times 40$ pc. Repository: GSC 137999.
Fig. 11. Spinidinium echinoideum, dorsal view of ventral surface. Location: Ogmund E-72, 1605 m. Sample: cs, YD15739, 3.

Optical parameters: A, $37.3 \times 108.0, \mathrm{H} 38 / 1, \times 60$ bf.

Repository: MGUH 31325.

Fig. 12. Spinidinium echinoideum, dorsal view, same specimen as fig. 11, focussed on ambitus.

Location: Ogmund E-72, 1605 m. Sample: cs, YD15739, 3.

Optical parameters: A, $37.3 \times 108.0, \mathrm{H} 38 / 1$, $\times 60$ bf.

Repository: MGUH 31325.

Fig. 13. Spiniferites ovatus, right lateral view. Location: Rut H-11, 755-765 m. Sample: cs, P39319, 1. Optical parameters: D, $135 \times 933, \mathrm{~N} 36 / 0, \times 40 \mathrm{pc}$. Repository: GSC 137923.

Fig. 14. Spiniferites pseudofurcatus. Location: Rut H-11, 2285-2295 m. Sample: cs, P39370, 1. Optical parameters: D, $128 \times 956, \mathrm{M} 38 / 4, \times 40 \mathrm{pc}$. Repository: GSC 137947.

Fig. 15. Spiniferites scabrosus.

Location: Roberval K-92, 3010 m. Sample: sw, P2008173, 1.

Optical parameters: C, $210 \times 1088$, V38/3-4, × 50 bf.

Repository: GSC 137906.

Fig. 16. Spongodinium delitiense, apical view. Location: Skolp E-07, 1070 m. Sample: cs, YD15580, 4. Optical parameters: A, 46.1×96.5, U47/1, × 60 bf. Repository: GSC 138143.

Fig. 17. Stichodinium lineidentatum, dorsal view of ventral surface. Location: Nukik-2, $1862 \mathrm{~m}$. Sample: cs, 05B2163, 3. Optical parameters: A, $43.6 \times 111.4$, D44/4, $\times 60$ bf. Repository: MGUH 31326.

Fig. 18. Stichodinium lineidentatum, dorsal view of dorsal surface, same specimen as fig. 17.

Location: Nukik-2, $1862 \mathrm{~m}$. Sample: cs, 05B2163, 3.

Optical parameters: A, $43.6 \times 111.4$, D44/4, × 60 bf.

Repository: MGUH 31326.

Fig. 19. Spongodinium obscurum, dorsal surface. Location: GGU 400712 borehole, 62.13-62.25 m. Sample: cc, D309-F, 3. Optical parameters: A, $32.0 \times 109.0, \mathrm{G} 32 / 3, \times 60$ bf. Repository: MGUH 31327.

Fig. 20. Spongodinium delitiense, right lateral view. Location: North Leif I-05, 2460-2470 m. Sample: cs, YD17611, 3. Optical parameters: E, $29.2 \times 18.0, \mathrm{~J} 27 / 2, \times 60$ bf. Repository: MGUH 31328. 


\section{Plate 13}
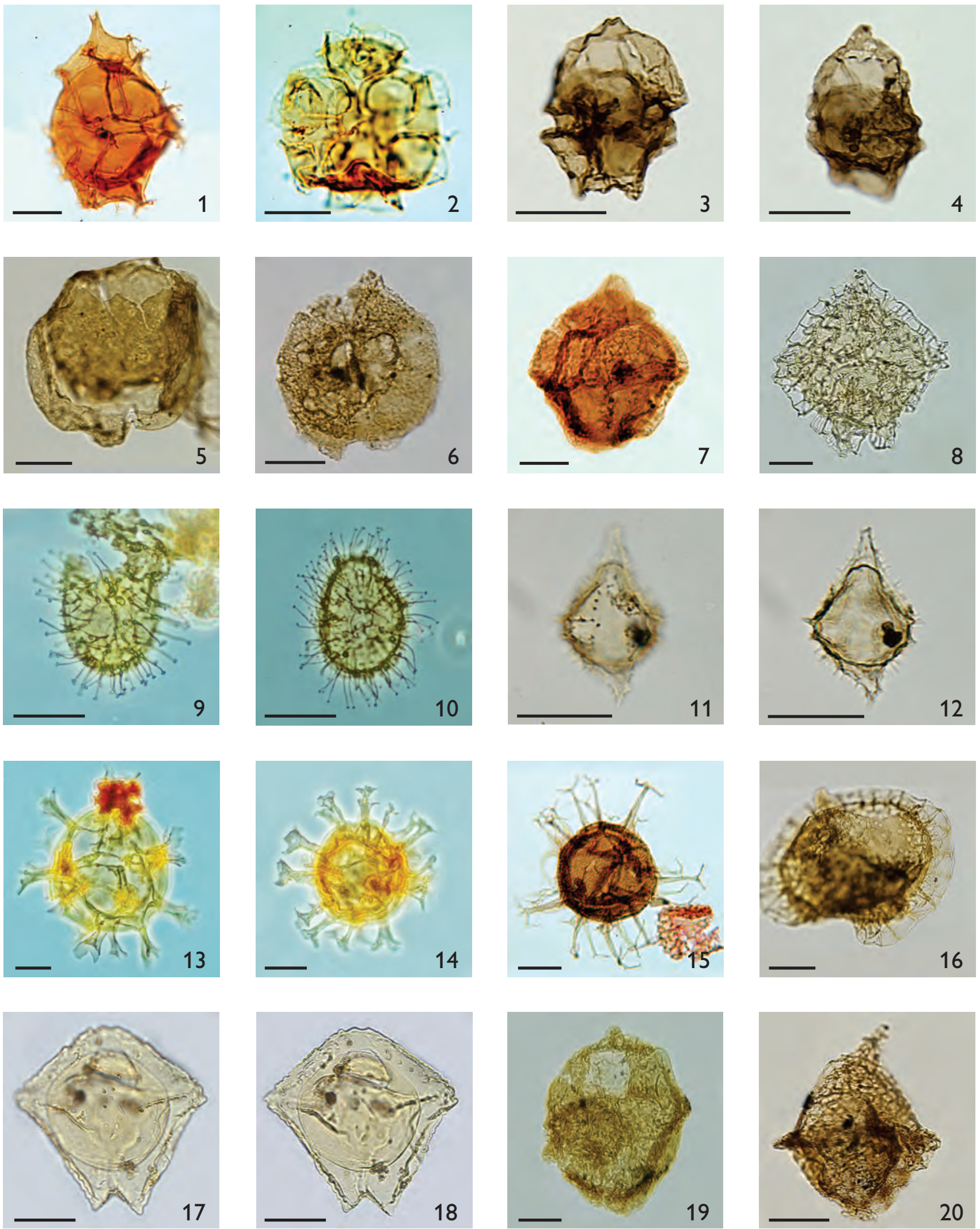


\section{Plate 14}

Fig. 1. Spongodinium grossum, oblique left lateral view. Location: Skolp E-07, 1565 m. Sample: cs, JEH15612, 3. Optical parameters: A, $29.5 \times 110.6$, E29/4, × 60 bf. Repository: MGUH 31329.

Fig. 2. Spongodinium grossum, left lateral view. Location: Skolp E-07, 1565 m. Sample: cs, JEH15612, 5. Optical parameters: A, $27.3 \times 98.5$, S27/2, × 60 bf. Repository: MGUH 31330.

Fig. 3. Spongodinium grossum, ventral surface. Location: Bjarni O-82, 2445-2455 m. Sample: cs, P39736, 1. Optical parameters: C, $181 \times 991$, S29/3, $\times 40$ bf. Repository: GSC 138075.

Fig. 4. Spongodinium grossum, same specimen as fig. 3, focussed on dorsal surface.

Location: Bjarni O-82, 2445-2455 m. Sample: cs, P39736, 1. Optical parameters: C, $181 \times 991$, S29/3, $\times 40$ bf. Repository: GSC 138075.

Fig. 5. Subtilisphaera perlucida, dorsal surface. Location: North Leif I-05, 2910-2920 m. Sample: cs, YD17626, 4. Optical parameters: E, $23.4 \times 19.2, \mathrm{H} 21 / 0, \times 60$ bf. Repository: GSC 138167.

Fig. 6. Surculosphaeridium convocatum sp. nov., ventral surface. Location: South Labrador N-79, 3510-3520 m. Sample: cs, P39834, 1. Optical parameters: C, $148 \times 982, \mathrm{P} 28 / 1, \times 50$ bf. Repository: GSC 138127.

Fig. 7. Surculosphaeridium convocatum sp. nov., holotype, dorsal surface.

Location: South Labrador N-79, 3510-3520 m. Sample: cs, P39834, 1. Optical parameters: C, $78 \times 991, \mathrm{G} 29 / 3-\mathrm{H} 28 / 2, \times 50$ bf. Repository: GSC 138128 .

Fig. 8. Surculosphaeridium convocatum sp. nov., lateral view. Location: North Leif I-05, 2760-2775 m. Sample: cs, YD17611, 2. Optical parameters: E, $21.9 \times 19.4, \mathrm{H} 20 / 1, \times 60$ bf. Repository: MGUH 31331.

Fig. 9. Talladinium? clathratum, dorsal view, focussed on ambitus. Location: Ralegh N-18, 1445 m. Sample: cs, YD16217, 2.

Optical parameters: E, $37.6 \times 14.5$, M36/4, × 40 bf. Repository: MGUH 31332.

Fig. 10. Talladinium? clathratum, dorsal view, same specimen as fig. 9 .

Location: Ralegh N-18, 1445 m. Sample: cs, YD16217, 2.

Optical parameters: E, $37.6 \times 14.5, \mathrm{M} 36 / 4, \times 60 \mathrm{bf}$.

Repository: MGUH 31332.
Fig. 11. Talladinium pellis sp. nov., holotype, dorsal view of dorsal surface.

Location: Gjoa O-37, 1840 m. Sample: cs, YD16082, 3.

Optical parameters: C, $21.9 \times 22.0$, E20/3, × 60 bf.

Repository: GSC 138082.

Fig. 12. Talladinium pellis sp. nov., holotype, dorsal view of ventral surface, same specimen as fig. 11 .

Location: Gjoa O-37, 1840 m. Sample: cs, YD16082, 3

Optical parameters: C, $21.9 \times 22.0$, E20/3, × 60 bf.

Repository: GSC 138082.

Fig. 13. Taurodinium granulatum sp. nov., holotype, dorso-ventral view.

Location: Ikermiut-1, 2340 m. Sample: cs, 2289 s-261, 3.

Optical parameters: B, $17.82 \times 9.01, \mathrm{~T} 19 / 1, \times 60$ bf.

Repository: MGUH 31333.

Fig. 14. Taurodinium granulatum sp. nov., dorso-ventral view. Location: Ralegh N-18, 3045 m. Sample: cs, YD16264, 3.

Optical parameters: E, $23.6 \times 14.8$, M21/4, × 60 bf.

Repository: MGUH 31334.

Fig. 15. Taurodinium granulatum sp. nov., dorso-ventral view. Location: Ralegh N-18, 3405 m. Sample: cs, YD16341, 3.

Optical parameters: E, $20.8 \times 16.9, \mathrm{~K} 19 / 3, \times 60 \mathrm{bf}$.

Repository: MGUH 31335.

Fig. 16. Talladinium pellis sp. nov., ventral view. Location: Gjoa O-37, 1840 m. Sample: cs, YD16082, 4. Optical parameters: C, $18.56 \times 15.03$, L20/1, × 60 bf. Repository: MGUH 31336.

Fig. 17. Taurodinium granulatum sp. nov., dorso-ventral view. Location: Ralegh N-18, 3425 m. Sample: cs, YD16342, 4.

Optical parameters: E, $33.0 \times 18.6, \mathrm{~J} 31 / 2, \times 60 \mathrm{bf}$. Repository: GSC 138147.

Fig. 18. Taurodinium granulatum sp. nov. Location: Hekja O-71, 3120 m. Sample: cs, JEH16030, 2.

Optical parameters: E, $24.9 \times 23.6, \mathrm{C} 23 / 3, \times 60 \mathrm{bf}$. Repository: MGUH 31337.

Fig. 19. Tenua hystrix, ventral view of dorsal surface. Location: Roberval K-92, 3090-3100 m. Sample: cs, P17727, 1.

Optical parameters: C, $175 \times 1086, S 38 / 2, \times 50$ bf. Repository: GSC 137900.

Fig. 20. Tenua hystrix, lateral view. Location: Two Snout Creek, Bylot Island, section 538080E, $105 \mathrm{~m}$ above base (sample HFB-09-42). Sample: os, P514833, D.

Optical parameters: C, $145 \times 918$, M55/3-4, × 50 bf. Repository: GSC 138129. 


\section{Plate 14}
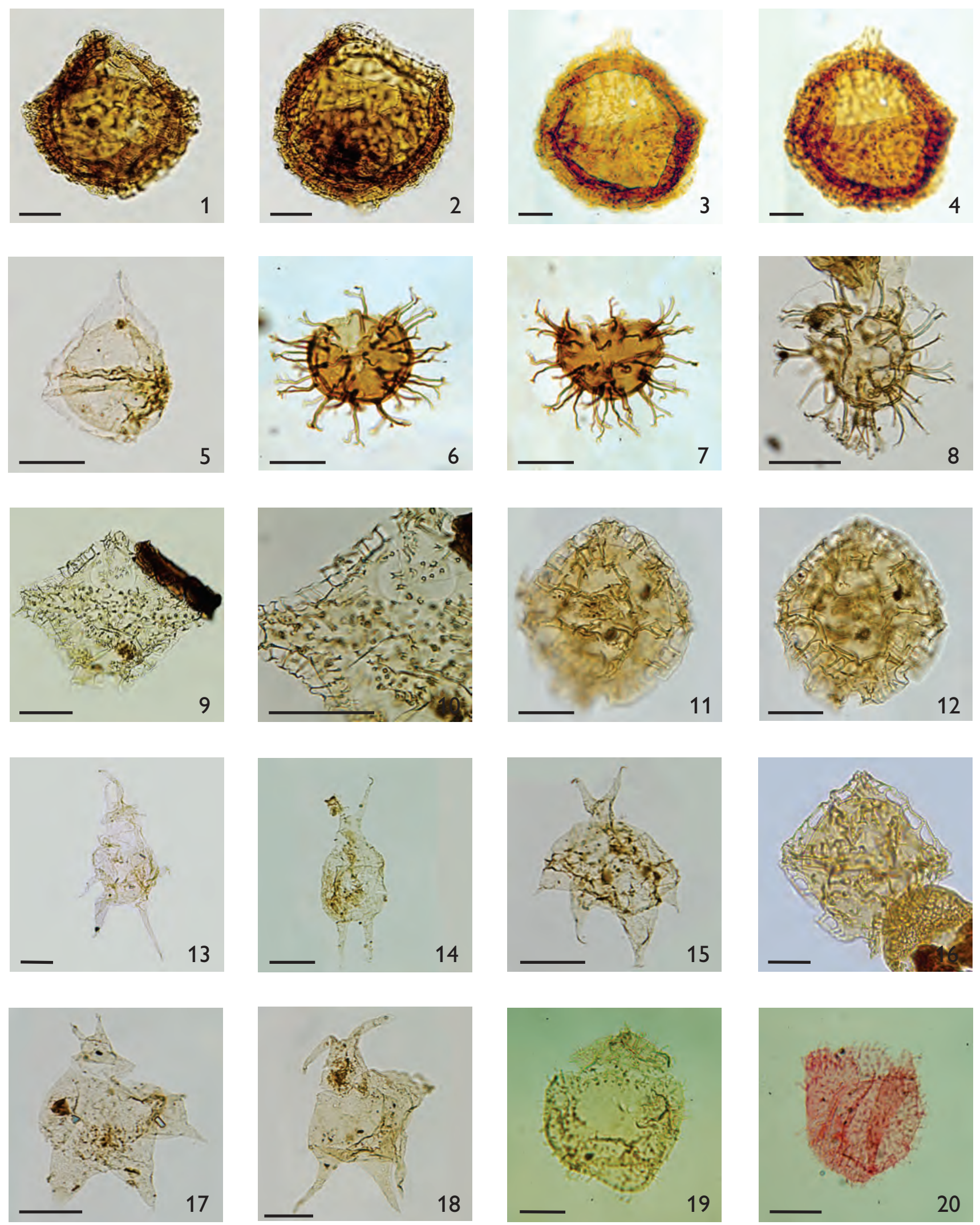


\section{Plate 15}

Fig. 1. Thalassiphora delicata, dorsal surface. Location: North Leif I-05, 2370-2380 m. Sample: cs, YD17608, 4. Optical parameters: E, $35.7 \times 12.9, \mathrm{P} 34 / 1, \times 60$ bf. Repository: MGUH 31338.

Fig. 2. Thalassiphora fenestrata, right lateral view. Location: Ralegh N-18, 1445 m. Sample: cs, YD16217, 2. Optical parameters: E, $32.5 \times 20.5$, F31/4, × 60 bf. Repository: MGUH 31339.

Fig. 3. Thalassiphora fenestrata, left lateral view. Location: Ralegh N-18, 1445 m. Sample: cs, YD16217, 2. Optical parameters: E, $41.1 \times 11.2$, Q40/2, × 60 bf. Repository: MGUH 31340.

Fig. 4. Thalassiphora fenestrata, dorso-ventral view. Location: Ralegh N-18, 1605 m. Sample: cs, YD16221, 4. Optical parameters: E, $32.8 \times 6.2, \mathrm{~V} 31 / 3, \times 40 \mathrm{bf}$. Repository: CNSOPB

Fig. 5. Thalassiphora pelagica, dorso-ventral view. Location: Rut H-11, 2765-2775 m. Sample: cs, P39386, 1. Optical parameters: D, $181 \times 906, \mathrm{~S} 33 / 0, \times 40 \mathrm{pc}$. Repository: GSC 137956.

Fig. 6. Thalassiphora pelagica, dorsal surface. Location: Karlsefni A-13, 2615.22-2624.36 m. Sample: cs, P39612, 1. Optical parameters: D, $52 \times 902, \mathrm{D} 33 / 3, \times 40 \mathrm{pc}$. Repository: GSC 138039.

Fig. 7. Tanyosphaeridium xanthiopyxides. Location: Gilbert F-53, 2590-2600 m. Sample: cs, P39499, 1 Optical parameters: C, $94 \times 1004, \mathrm{~J} 30 / 0, \times 50 \mathrm{bf}$ Repository: GSC 137984

Fig. 8. Trichodinium castanea, oblique left lateral view. Location: Skolp E-07, 1430 m. Sample: cs, YD15603, 3. Optical parameters: A, $36.0 \times 100.7$, Q356/2, × 60 bf. Repository: MGUH 31341.

Fig. 9. Trithyrodinium? conservatum sp. nov., dorso-ventral view, with focus on ambitus.

Location: Ikermiut-1, 1155 m. Sample: sw, 04E006504, 3.

Optical parameters: A, $33.0 \times 112.8, \mathrm{C} 33 / 3, \times 60 \mathrm{bf}$. Repository: MGUH 26500.

Fig. 10. Trithyrodinium? conservatum sp. nov., dorso-ventral view. Location: Ikermiut-1, 1155 m. Sample: sw, 04E006504, 2. Optical parameters: A, $41.0 \times 113.5$, C41/2, × 60 bf. Repository: MGUH 26501.
Fig. 11. Trithyrodinium? conservatum sp. nov., dorso-ventral view, same specimen as fig. 10, focussed on dorsal surface. Location: Ikermiut-1, 1155 m. Sample: sw, 04E006504, 2. Optical parameters: A, $41.0 \times 113.5, \mathrm{C} 41 / 2, \times 60 \mathrm{bf}$. Repository: MGUH 26501.

Fig. 12. Trithyrodinium? conservatum sp. nov., holotype, dorsal surface.

Location: Ikermiut-1, 1155 m. Sample: sw, 04E006504, 2.

Optical parameters: A, $36.0 \times 97.1, \mathrm{U} 36 / 1, \times 60 \mathrm{bf}$. Repository: MGUH 26502.

Fig. 13. Trithyrodinium? conservatum sp. nov., dorsal surface. Location: Ralegh N-18, 1485 m. Sample: cs, YD16218, 2.

Optical parameters: E, $30.3 \times 23.1$, D29/1, × 60 bf. Repository: MGUH 31342.

Fig. 14. Trithyrodinium? conservatum sp. nov., dorsal surface. Location: Ralegh N-18, 1525 m. Sample: cs, YD16219, 2. Optical parameters: E, $28.7 \times 5.8$, W27/2, × 60 bf. Repository: MGUH 31343.

Fig. 15. Trithyrodinium suspectum, dorso-ventral view. Location: Skolp E-07, 2375 m. Sample: cs, YD15665, 4. Optical parameters: A, $39.0 \times 107.4, \mathrm{H} 39 / 4, \times 60 \mathrm{bf}$. Repository: MGUH 31344.

Fig. 16. Trithyrodinium quinqueangulare, oblique dorsoventral view.

Location: South Labrador N-79, 3300-3310 m. Sample: cs, P39827, 1.

Optical parameters: C, $223 \times 1020$, W32-X31, × 50 bf. Repository: GSC 138125.

Fig. 17. Trithyrodinium evittii, oblique apical view. Location: North Leif I-05, 2370-2380 m. Sample: cs, YD17608, 3. Optical parameters: E, $24.5 \times 11.0, \mathrm{Q} 23 / 3$, $\times 60 \mathrm{bf}$. Repository: MGUH 31345.

Fig. 18. Trithyrodinium evittii, dorsal surface. Location: Gilbert F-53, 2920-2930 m. Sample: cs, P39510, 1. Optical parameters: C, $100 \times 1067, \mathrm{~K} 36 / 3-4, \times 50$ bf. Repository: GSC 137989.

Fig. 19. Trithyrodinium evittii, apical view. Location: Roberval K-92, 3090-3100 m. Sample: cs, P17727, 1. Optical parameters: C, $197 \times 1095$, U39/0-2, × 50 bf Repository: GSC 137901.

Fig. 20. Tuberculodinium vancampoae, apical view. Location: Karlsefni A-13, 557.79-566.93 m. Sample: cs, P39538, 1. Optical parameters: D, $146 \times 1038, \mathrm{P} 46 / 2, \times 40$ pc. Repository: GSC 137993. 


\section{Plate 15}
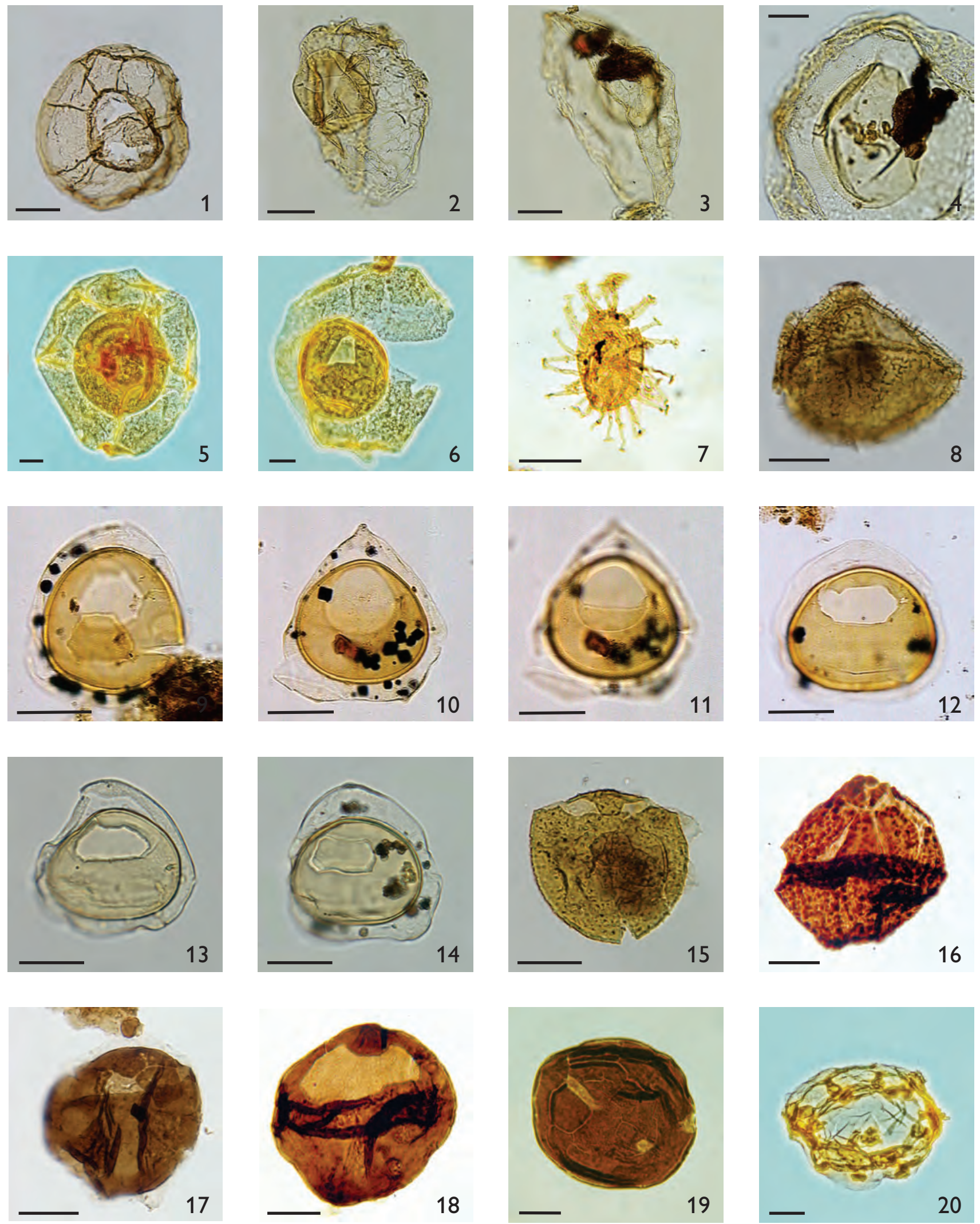


\section{Plate 16}

Fig. 1. Vesperopsis longicornis, dorso-ventral view. Location: North Leif I-05, 3360-3370 m. Sample: cs, YD17641, 4. Optical parameters: E, $55.6 \times 10.1, \mathrm{R} 55 / 1, \times 60 \mathrm{bf}$. Repository: MGUH 31346.

Fig. 2. Vesperopsis longicornis, dorso-ventral view. Location: North Leif I-05, 3360-3370 m. Sample: cs, YD17641, 3. Optical parameters: E, $35.2 \times 23.4$, C34/1, × 60 bf. Repository: MGUH 31347.

Fig. 3. Wetzeliella articulata, dorsal view. Location: Rut H-11, 3725-3735 m. Sample: cs, P39417, 1. Optical parameters: D, $152 \times 847, \mathrm{P} 27 / 0, \times 40 \mathrm{pc}$. Repository: GSC 137971.

Fig. 4. Wetzeliella articulata, dorsal view. Location: Rut H-11, 3095-3105 m. Sample: cs, P39397, 1. Optical parameters: D, $81 \times 949, \mathrm{G} 38 / 3, \times 40 \mathrm{pc}$. Repository: GSC 137963.

Fig. 5. Wallodinium luna, lateral view. Location: Skolp E-07, 1610 m. Sample: cs, JEH15615, 3. Optical parameters: A, $39.6 \times 100.2$, R40/1, × 60 bf. Repository: MGUH 31348.

Fig. 6. Xenascus wetzelii, dorsal view of dorsal surface. Location: Skolp E-07, 1475 m. Sample: cs, YD15606, 3. Optical parameters: A, $41.0 \times 111.2$, E41/2, x 40 bf. Repository: MGUH 31349.

Fig. 7. Xenascus wetzelii, dorsal view, same specimen as fig. 6, showing enlarged view of ventral surface.

Location: Skolp E-07, 1475 m. Sample: cs, YD15606, 3.

Optical parameters: A, $41.0 \times 111.2$, E41/2, × 60 bf.

Repository: MGUH 31349.

Fig. 8. Xenascus wetzelii, dorsal view, same specimen as fig. 6, showing enlarged view of dorsal surface.

Location: Skolp E-07, 1475 m. Sample: cs, YD15606, 3.

Optical parameters: A, $41.0 \times 111.2$, E41/2, × 60 bf.

Repository: MGUH 31349.

Fig. 9. Xenascus ceratioides, ventral view.

Location: Rut H-11, 2255-2235 m. Sample: cs, P39369, 1.

Optical parameters: D, $116 \times 954, \mathrm{~L} 38 / 0, \times 40 \mathrm{pc}$.

Repository: GSC 137945.

Fig. 10. Xenascus ceratioides, dorsal view. Location: Skolp E-07, 2435 m. Sample: cs, YD15669, 3. Optical parameters: A, $24.6 \times 107.9, \mathrm{H} 24 / 2, \times 60 \mathrm{bf}$. Repository: GSC 138144.
Fig. 11. Fromea quadrangularis sp. nov. Location: Skolp E-07, 2075 m. Sample: cs, JEH15643, 3. Optical parameters: A, $42.1 \times 94.3$, W43/3, × 60 bf. Repository: MGUH 31350.

Fig. 12. Fromea quadrangularis sp. nov. Location: Skolp E-07, 2090 m. Sample: cs, JEH15644, 5. Optical parameters: A, $44.2 \times 109.3, \mathrm{G} 45 / 1, \times 60$ bf. Repository: GSC 137882.

Fig. 13. Microsphaeridium ancistroides. Location: Rut H-11, 665-675 m. Sample: cs, P39316, 1. Optical parameters: D, $108 \times 900, \mathrm{~K} 33 / 3, \times 40 \mathrm{pc}$. Repository: GSC 137917.

Fig. 14. Microsphaeridium ancistroides.

Location: Rut H-11, 1835-1845 m. Sample: cs, P39355, 1.

Optical parameters: D, $186 \times 907$, S33/3-4, $\times 40$ pc. Repository: GSC 137941.

Fig. 15. Fromea quadrangularis sp. nov. Location: Skolp E-07, 2360 m. Sample: cs, YD15664, 2. Optical parameters: A, $47.6 \times 99.1$, R45/4, × 60 bf. Repository: MGUH 31351.

Fig. 16. Fromea quadrangularis sp. nov., holotype. Location: Skolp E-07, 2375 m. Sample: cs, YD15665, 4. Optical parameters: A, $30.9 \times 111.9, \mathrm{D} 31 / 1, \times 60 \mathrm{bf}$. Repository: MGUH 31352.

Fig. 17. Microsphaeridium ancistroides.

Location: Karlsefni A-13, 667.52-676.66 m. Sample: cs, P39542, 1.

Optical parameters: D, $170 \times 946, \mathrm{R} 37 / 2, \times 40 \mathrm{pc}$. Repository: GSC 137994.

Fig. 18. Microsphaeridium ancistroides.

Location: Rut H-11, 665-675 m. Sample: cs, P39316, 1.

Optical parameters: D, $135 \times 1003, \mathrm{~N} 43 / 0, \times 40 \mathrm{pc}$.

Repository: GSC 137918.

Fig. 19. Fromea nicosia.

Location: Skolp E-07, 2360 m. Sample: cs, YD15664, 2.

Optical parameters: A, $25.5 \times 93.1, \mathrm{X} 25 / 0, \times 60 \mathrm{bf}$.

Repository: MGUH 31353.

Fig. 20. Palambages sp.

Location: Rut H-11, 2405-2415 m. Sample: cs, P39374, 1.

Optical parameters: D, $169 \times 1003, \mathrm{R} 43 / 1-2, \times 40 \mathrm{pc}$.

Repository: GSC 137951. 


\section{Plate 16}
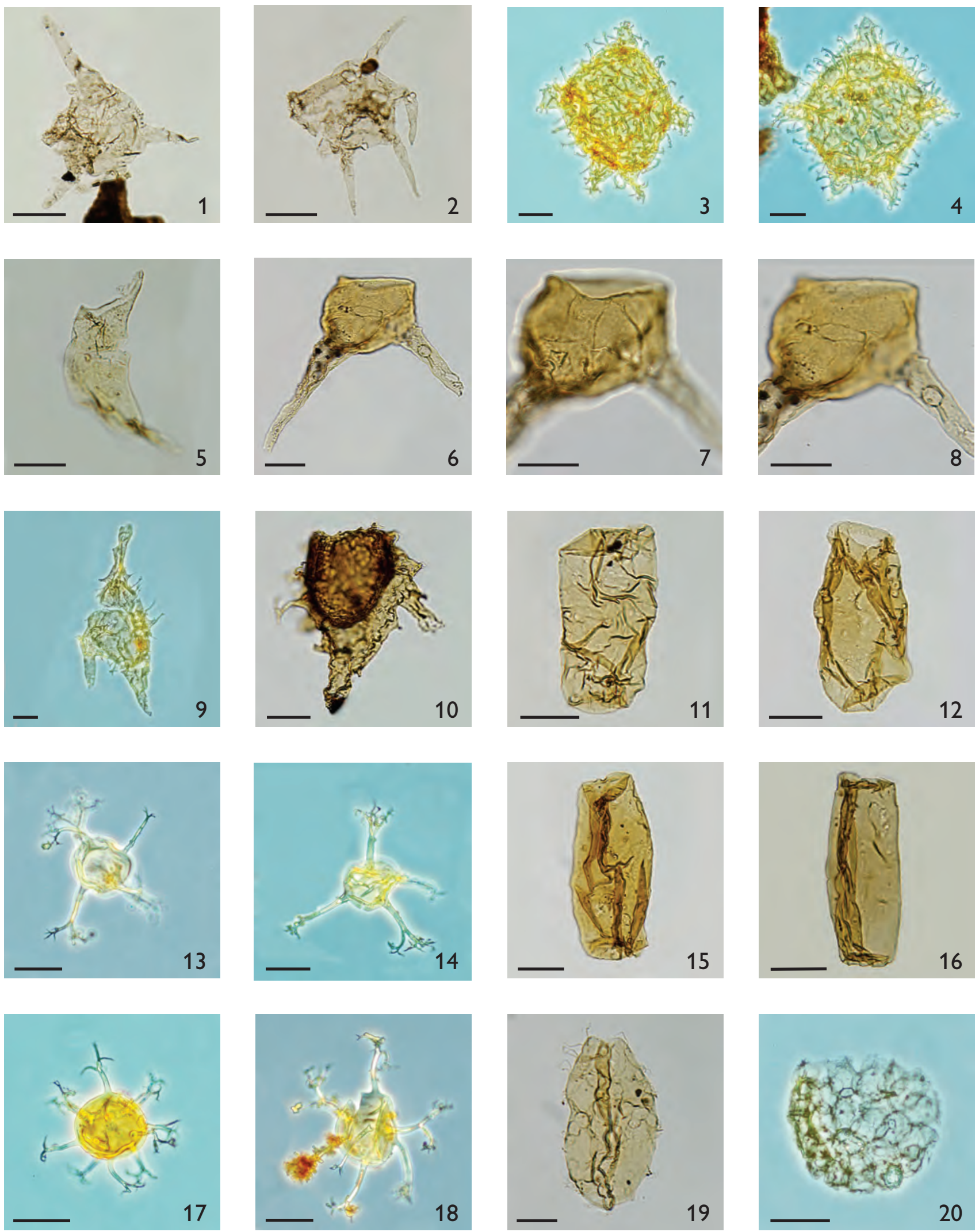


\section{Plate 17}

Fig. 1. Paralecaniella indentata.

Location: Karlsefni A-13, 2176.30-2185.44 m. Sample: cs, P39596, 1.

Optical parameters: D, $162 \times 873, \mathrm{Q} 30 / 1, \times 40 \mathrm{pc}$.

Repository: GSC 138024.

Fig. 2. Paralecaniella indentata.

Location: Hellefisk-1, 1588 m. Sample: sw, 02E6529-3, 3.

Optical parameters: A, $30.5 \times 106.3, \mathrm{~K} 30 / 0, \times 60 \mathrm{bf}$.

Repository: MGUH 26544.

Fig. 3. Pediastrum sp.

Location: Rut H-11, 1865-1875 m. Sample: cs, P39356, 1.

Optical parameters: D, $136 \times 1057, \mathrm{~N} 49 / 3, \times 40 \mathrm{pc}$.

Repository: GSC 137943.

Fig. 4. Pediastrum sp.

Location: Karlsefni A-13, 2286.03-2295.17 m. Sample: cs, P39600, 1.

Optical parameters: D, $167 \times 1007, \mathrm{Q} 44 / 3, \times 40$ pc.

Repository: GSC 138032.

Fig. 5. Tetraporina sp. A.

Location: Gjoa O-37, 1680 m. Sample: cs, YD16076, 2.

Optical parameters: E, $23.1 \times 14.4, \mathrm{~N} 21 / 0$, $\times 60 \mathrm{bf}$.

Repository: MGUH 31354.

Fig. 6. Tetraporina sp. A.

Location: North Leif I-05, 540-550 m. Sample: cs, YD17547, 3.

Optical parameters: E, $37.0 \times 11.3$, Q35/4, × 60 bf.

Repository: GSC 138148.

Fig. 7. Tetraporina sp. A.

Location: Karlsefni A-13, 2011.70-2020.85 m. Sample: cs, P39590, 1.

Optical parameters: D, $191 \times 923, \mathrm{~T} 35 / 0, \times 40 \mathrm{pc}$.

Repository: GSC 138021.

Fig. 8. Tetraporina sp. B.

Location: Rut H-11, 3035-3045 m. Sample: cs, P39395, 1.

Optical parameters: D, $134 \times 931, \mathrm{~N} 36 / 0, \times 40$ pc.

Repository: GSC 137962.

Fig. 9. Tetraporina sp. B.

Location: Gjoa O-37, 1620 m. Sample: cs, YD16074, 4.

Optical parameters: A, $42.5 \times 98.2, \mathrm{~S} 43 / 0, \times 60 \mathrm{bf}$.

Repository: MGUH 31355.

Fig. 10. Tetraporina sp. B.

Location: Gjoa O-37, 1620 m. Sample: cs, YD16074, 4.

Optical parameters: A, $34.0 \times 105.0$, L34/0, $\times 60$ bf.

Repository: MGUH 31356.
Fig. 11. Tetraporina sp. B.

Location: Skolp E-07, 935 m. Sample: cs, YD15568, 4.

Optical parameters: A, $22.5 \times 98.4, \mathrm{~S} 22 / 2, \times 60$ bf.

Repository: GSC 138141.

Fig. 12. Tetraporina sp. B.

Location: Rut H-1 1, 3485-3495 m. Sample: cs, P39410, 1.

Optical parameters: D, $164 \times 904, \mathrm{Q} 33 / 1-3, \times 40 \mathrm{pc}$.

Repository: GSC 137968.

Fig. 13. Translucentipollis contiguus.

Location: Rut H-11, 3785-3795 m. Sample: cs, P39419, 1.

Optical parameters: D, $155 \times 978, \mathrm{P} 40 / 4, \times 40 \mathrm{pc}$.

Repository: GSC 137973.

Fig. 14. Aquilapollenites quadrilobus.

Location: Karlsefni A-13, 1956.84-1965.98 m. Sample: cs, P39588, 1.

Optical parameters: D, $138 \times 1037, \mathrm{~N} 47 / 3, \times 40 \mathrm{pc}$.

Repository: GSC 138019.

Fig. 15. Aquilapollenites quadrilobus.

Location: Bjarni O-82, 799-800 m. Sample: cs, P39681, 1.

Optical parameters: C, $220 \times 1048$, W34/4, × 40 bf.

Repository: GSC 138068.

Fig. 16. Parviprojectus reticulatus.

Location: Rut H-11, 3605-3615 m. Sample: cs, P39413, 1.

Optical parameters: D, $198 \times 855, \mathrm{U} 28 / 1, \times 40 \mathrm{pc}$.

Repository: GSC 137969.

Fig. 17. Aquilapollenites quadrilobus.

Location: Hekja O-71, 2080 m. Sample: cs, JEH16005, 1.

Optical parameters: C, $145 \times 1007, \mathrm{O} 30 / 4-\mathrm{P} 30 / 2, \times 50$ bf.

Repository: GSC 137884.

Fig. 18. Afropollis sp.

Location: Ogmund E-72, 1845 m. Sample: cs, YD15755, 3.

Optical parameters: A, $26.4 \times 101.8, \mathrm{O} 26 / 4, \times 60$ bf.

Repository: MGUH 31357.

Fig. 19. Afropollis sp.

Location: Ogmund E-72, 1845 m. Sample: cs, YD15755, 3.

Optical parameters: A, $26.8 \times 96.7, \mathrm{U} 27 / 1, \times 60 \mathrm{bf}$.

Repository: MGUH 31358.

Fig. 20. Appendicisporites potomacensis.

Location: Ogmund E-72, 2340 m. Sample: cs, JEH15877, 3.

Optical parameters: A, $16.3 \times 111.3, \mathrm{D} 16 / 3, \times 60$ bf.

Repository: MGUH 31359. 
Plate 17
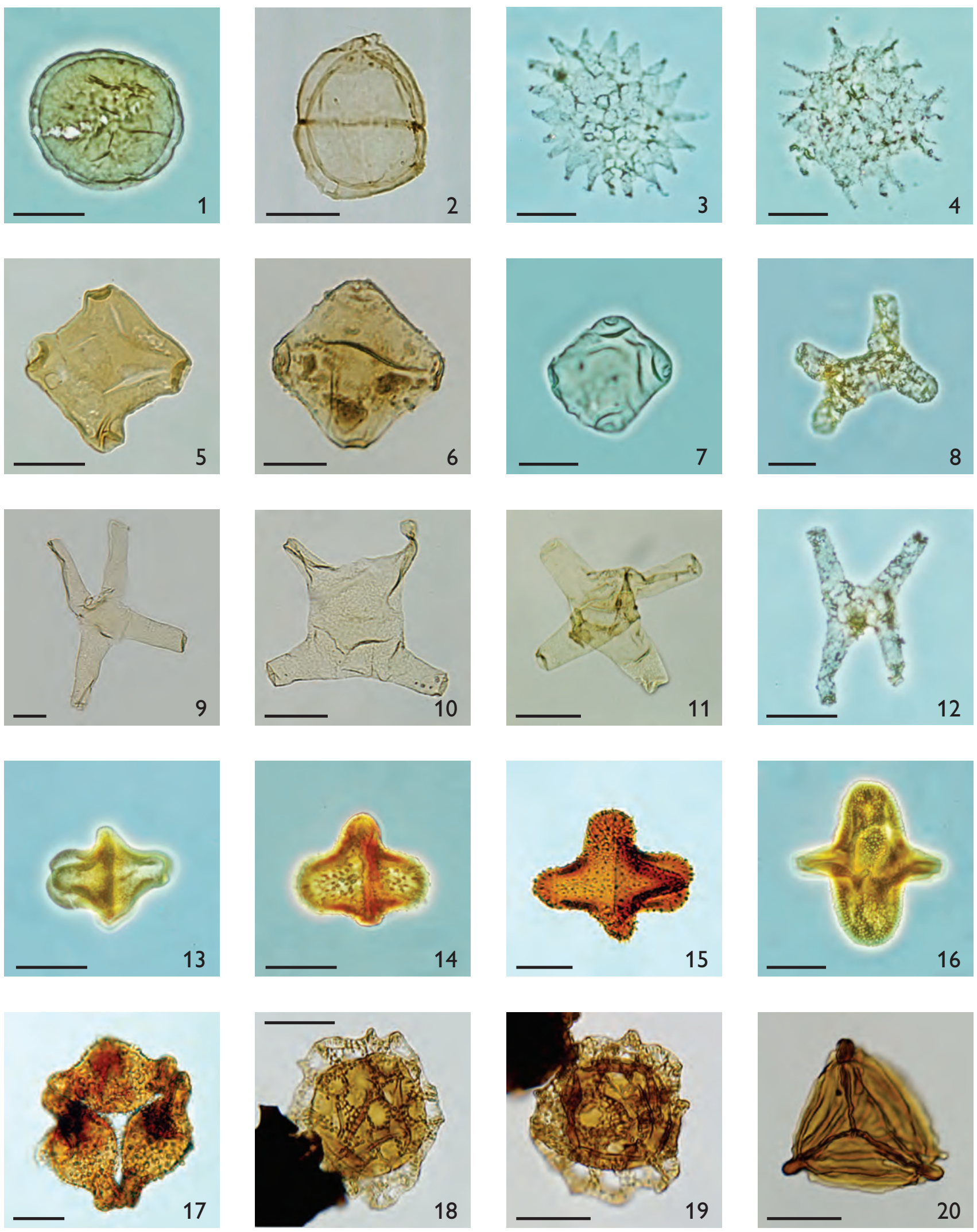


\section{Plate 18}

Fig. 1. Appendicisporites unicus.

Location: Ogmund E-72, 2205 m. Sample: cs, JEH15868, 3.

Optical parameters: A, $28.6 \times 102.6$, N28/4, × 60 bf.

Repository: GSC 137883.

Fig. 2. Azolla sp.

Location: Ralegh N-18, 2885 m. Sample: cs, YD16260, 3.

Optical parameters: E, $25.1 \times 8.1$, T23/2, $\times 60$ bf.

Repository: MGUH 31360.

Fig. 3. Azolla sp.

Location: Gjoa O-37, 1858-1868 m. Sample: cs, P16963, 1.

Optical parameters: C, $50 \times 1011, \mathrm{E} 31 / 1, \times 50 \mathrm{bf}$.

Repository: GSC 137886.

Fig. 4. Azolla sp.

Location: Karlsefni A-13, 2395.76-2404.90 m. Sample: cs, P39604, 1.

Optical parameters: D, $153 \times 1034, \mathrm{P} 46 / 2-4, \times 40 \mathrm{pc}$.

Repository: GSC 138034.

Fig. 5. Cicatricososporites eocenicus.

Location: South Labrador N-79, 2040-2050 m. Sample: cs, P39786, 1.

Optical parameters: C, $187 \times 1040$, T32/1-T33/2, × 50 bf.

Repository: GSC 138118.

Fig. 6. Baculatisporites crenulatus sp. nov.

Location: Roberval K-92, 2090-2100 m. Sample: cs, P17692, 1.

Optical parameters: C, $45 \times 1091$, D39/0, × 50 bf.

Repository: GSC 137890.

Fig. 7. Baculatisporites crenulatus sp. nov.

Location: Roberval K-92, 2150-2160 m. Sample: cs, P17696, 1.

Optical parameters: C, $63 \times 1073, \mathrm{~F} 37 / 0, \times 50 \mathrm{bf}$.

Repository: GSC 137891.

Fig. 8. Baculatisporites crenulatus sp. nov., holotype.

Location: Roberval K-92, 1790-1800 m. Sample: cs, P17684, 1.

Optical parameters: C, $106 \times 1048, \mathrm{~L} 34 / 2, \times 50$ bf.

Repository: GSC 137889.

Fig. 9. Caryapollenites inelegans.

Location: Karlsefni A-13, 969.28-978.42 m. Sample: cs, P39553, 1.

Optical parameters: D, $81 \times 1060, \mathrm{H} 49 / 2, \times 40 \mathrm{pc}$.

Repository: GSC 138003.

Fig. 10. Caryapollenites inelegans.

Location: Rut H-11, 845-855 m. Sample: cs, P39322, 1.

Optical parameters: D, $112 \times 844, \mathrm{~L} 27 / 1, \times 40 \mathrm{pc}$.

Repository: GSC 137925.
Fig. 11. Caryapollenites veripites.

Location: Karlsefni A-13, 2231.16-2240.31 m. Sample: cs, P39598, 1.

Optical parameters: D, $191 \times 993, \mathrm{~T} 42 / 0, \times 40 \mathrm{pc}$.

Repository: GSC 138028.

Fig. 12. Caryapollenites veripites.

Location: Karlsefni A-13, 3843.57-3852.72 m. Sample: cs, P39656, 1.

Optical parameters: D, $164 \times 867, \mathrm{Q} 29 / 0, \times 40 \mathrm{pc}$.

Repository: GSC 138056.

Fig. 13. Momipites annellus.

Location: Karlsefni A-13, 3904.54-3913.68 m. Sample: cs, P39658, 1.

Optical parameters: D, $175 \times 911, \mathrm{R} 34 / 3, \times 40 \mathrm{pc}$.

Repository: GSC 138058.

Fig. 14. Momipites annellus.

Location: Karlsefni A-13, 3301.02-3310.17 m. Sample: cs, P39637, 1.

Optical parameters: D, $122 \times 917, \mathrm{M} 34 / 0, \times 40 \mathrm{pc}$.

Repository: GSC 138051.

Fig. 15. Momipites coryloides.

Location: Snorri J-90, 1033.28-1043.43 m. Sample: cs, P9709, 10.

Optical parameters: C, $103 \times 1078, \mathrm{~K} 37-\mathrm{K} 38, \times 50$ bf.

Repository: GSC 138133.

Fig. 16. Callialasporites dampieri.

Location: Karlsefni A-13, 969.28-978.42 m. Sample: cs, P39553, 1.

Optical parameters: D, $196 \times 1026, \mathrm{~T} 45 / 4, \times 40 \mathrm{pc}$.

Repository: GSC 138006.

Fig. 17. Chenopodipollis sp.

Location: Karlsefni A-13, 911.36-920.51 m. Sample: cs, P39551, 1.

Optical parameters: D, $115 \times 930, \mathrm{~L} 35 / 2-4, \times 40 \mathrm{pc}$.

Repository: GSC 138001.

Fig. 18. Compositoipollenites sp. B. of Williams \& Brideaux 1975. Location: Karlsefni A-13, 1435.63-1444.77 m. Sample: cs, P39570, 1. Optical parameters: D, $187 \times 934, \mathrm{~S} 36 / 3, \times 40 \mathrm{pc}$.

Repository: GSC 138012.

Fig. 19. Corsinipollenites oculusnoctis.

Location: South Labrador N-79, 1110-1120 m. Sample: cs, P39757, 1.

Optical parameters: C, $200 \times 1018, \mathrm{U} 31 / 1-4, \times 50 \mathrm{bf}$.

Repository: GSC 138080.

Fig. 20. Corsinipollenites oculusnoctis.

Location: Karlsefni A-13, 1709.95-1719.09 m. Sample: cs, P39579, 1.

Optical parameters: D, $196 \times 1042, \mathrm{~T} 47 / 3, \times 40 \mathrm{pc}$.

Repository: GSC 138014. 
Plate 18
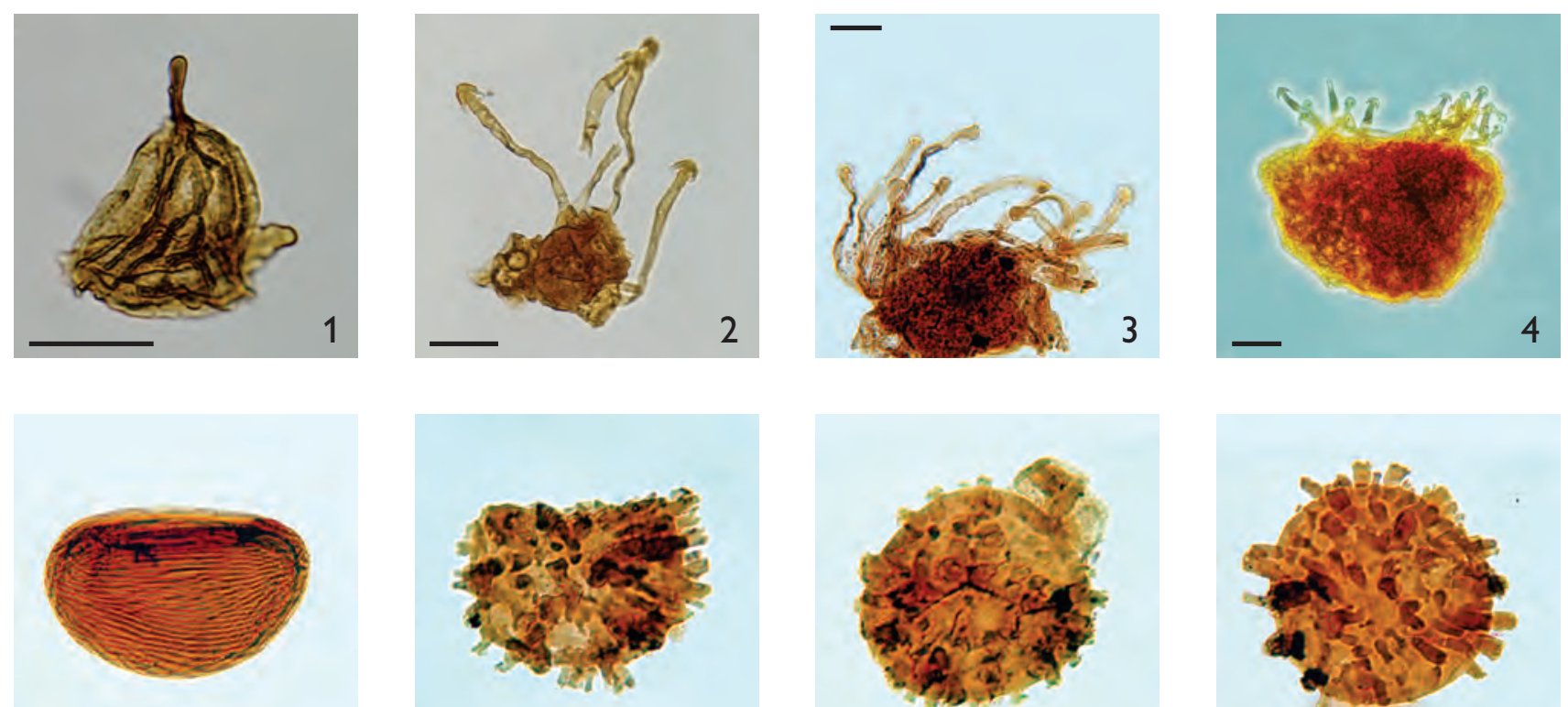

5

6
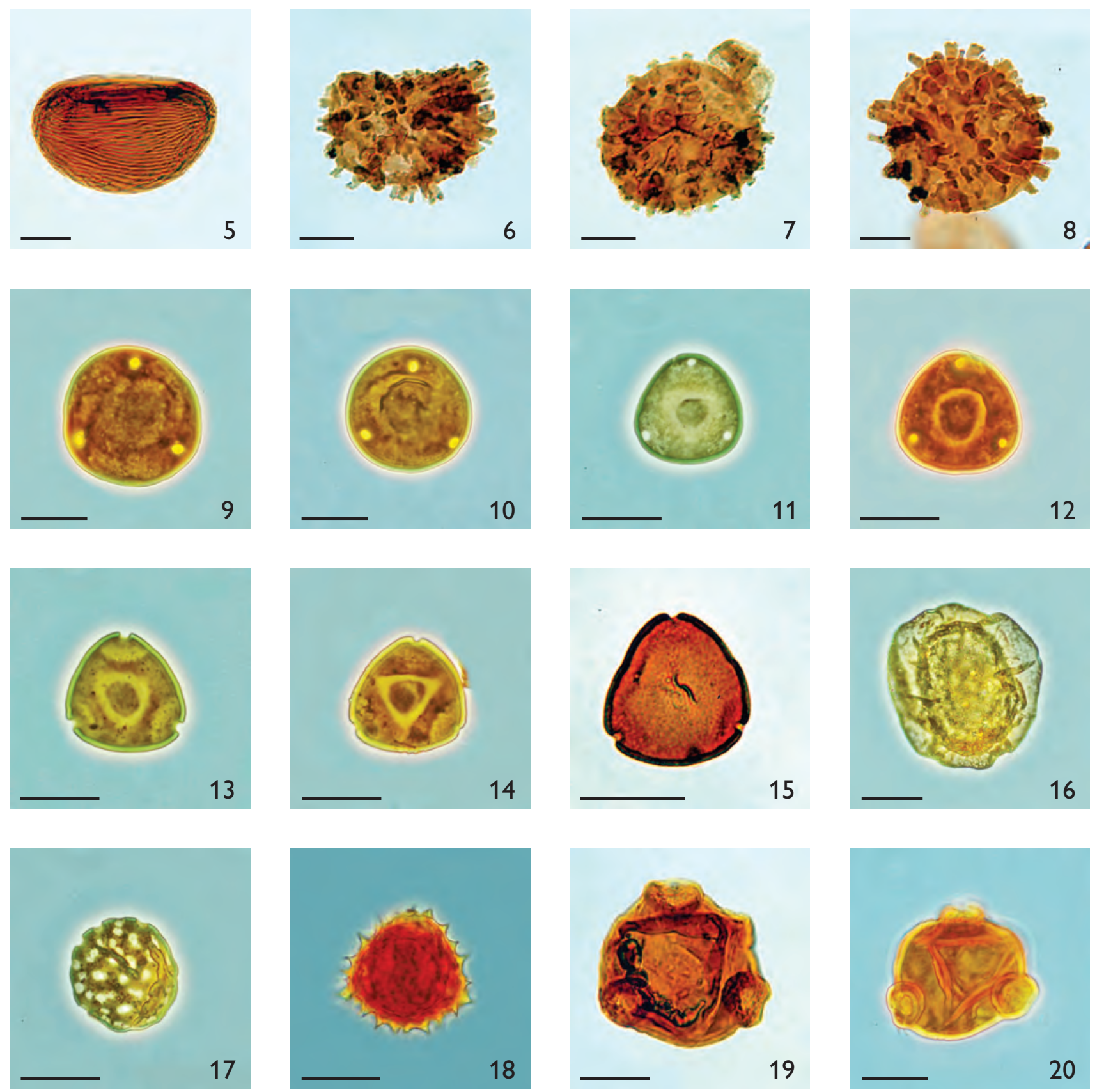


\section{Plate 19}

Fig. 1. Cicatricosisporites ornatus.

Location: Rut H-11, 2315-2325 m. Sample: cs, P39371, 1.

Optical parameters: D, $163 \times 885$, Q31/0, $\times 40$ pc.

Repository: GSC 137949 .

Fig. 2. Cicatricosisporites ornatus.

Location: Rut H-11, 1865-1875 m. Sample: cs, P39356, 1.

Optical parameters: D, $115 \times 881, \mathrm{~L} 30 / 2-4, \times 40 \mathrm{pc}$.

Repository: GSC 137942.

Fig. 3. Cicatricosisporites ornatus.

Location: Karlsefni A-13, 2532.98-2542.08 m. Sample: cs, P39609, 1.

Optical parameters: D, $163 \times 873, \mathrm{Q} 30 / 1-3, \times 40 \mathrm{pc}$.

Repository: GSC 138038.

Fig. 4. Cicatricosisporites ornatus.

Location: Rut H-11, 3695-3705 m. Sample: cs, P39416, 1.

Optical parameters: D, $90 \times 993, \mathrm{H} 42 / 3-4, \times 40 \mathrm{pc}$.

Repository: GSC 137970.

Fig. 5. Extratriporopollenites sp.

Location: Gilbert F-53, 1540-1550 m. Sample: cs, P39464, 1.

Optical parameters: C, $180 \times 1043$, S34/0, × 50 bf.

Repository: GSC 137975.

Fig. 6. Extratriporopollenites sp.

Location: Hekja O-71, 1610-1620 m. Sample: cs, P20568, 1.

Optical parameters: C, $197 \times 1032, \mathrm{U} 33 / 1, \times 50$ bf.

Repository: GSC 137914

Fig. 7. Extratriporopollenites sp.

Location: Hekja O-71, 1420-1430 m. Sample: cs, P20562, 1.

Optical parameters: C, $80 \times 1077, \mathrm{H} 37 / 2, \times 50$ bf.

Repository: GSC 137913.

Fig. 8. Extratriporopollenites sp.

Location: Snorri J-90, 1892.83-1901.98 m. Sample: cs, P9737, 1.

Optical parameters: C, $135 \times 1020, \mathrm{~N} 31 / 4-\mathrm{N} 32 / 3, \times 50$ bf.

Repository: GSC 138135.

Fig. 9. Extratriporopollenites sp.

Location: South Labrador N-79, 780-790 m. Sample: cs, P39746, 1.

Optical parameters: C, $154 \times 1018, \mathrm{P} 31 / 4, \times 50$ bf.

Repository: GSC 138078 .

Fig. 10. Periporopollenites sp.

Location: Karlsefni A-13, 2176.30-2185.44 m. Sample: cs, P39596, 1.

Optical parameters: D, $109 \times 957, \mathrm{~K} 38 / 4, \times 40 \mathrm{pc}$.

Repository: GSC 138023
Fig. 11. Periporopollenites sp.

Location: Rut H-11, 1305-1315 m. Sample: cs, P39337, 1.

Optical parameters: D, $148 \times 859, \mathrm{O} 28 / 0, \times 40 \mathrm{pc}$.

Repository: GSC 137935.

Fig. 12. Graminidites sp. A of Williams \& Brideaux 1975.

Location: Rut H-11, 1685-1695 m. Sample: cs, P39350, 1.

Optical parameters: D, $177 \times 882, \mathrm{R} 31 / 3, \times 40 \mathrm{pc}$.

Repository: GSC 137937.

Fig. 13. Pistillipollenites macgregorii.

Location: Snorri J-90, 2441.48-2450.62 m. Sample: cs, P9751, 10.

Optical parameters: C, $30 \times 910, \mathrm{C} 20 / 0, \times 50 \mathrm{bf}$.

Repository: GSC 138140.

Fig. 14. Pistillipollenites macgregorii.

Location: Gjoa O-37, 1620-1630 m. Sample: cs, P16951, 1.

Optical parameters: C, $65 \times 1174, \mathrm{~F} 37 / 4, \times 50$ bf.

Repository: GSC 137885.

Fig. 15. Quercoidites sp.

Location: Rut H-11, 1205-1215 m. Sample: cs, P39334, 1.

Optical parameters: D, $119 \times 869, \mathrm{~L} 29 / 4, \times 40 \mathrm{pc}$.

Repository: GSC 137930.

Fig. 16. Quercoidites sp.

Location: Rut H-11, 1305-1315 m. Sample: cs, P39337, 1.

Optical parameters: D, $102 \times 957, \mathrm{~K} 38 / 2, \times 40 \mathrm{pc}$.

Repository: GSC 137934.

Fig. 17. Tiliaepollenites crassipites.

Location: South Labrador N-79, 1110-1120 m. Sample: cs, P39757, 1.

Optical parameters: C, $182 \times 1009, \mathrm{~S} 30 / 2, \times 50$ bf.

Repository: GSC 138079.

Fig. 18. Tiliaepollenites crassipites.

Location: South Labrador N-79, 780-790 m. Sample: cs, P39746, 1.

Optical parameters: C, $134 \times 1023, \mathrm{~N} 32 / 3, \times 50$ bf.

Repository: GSC 138077.

Fig. 19. Tiliaepollenites sp. A.

Location: Rut H-11, 1565-1575 m. Sample: cs, P39346, 1.

Optical parameters: D, $190 \times 928, \mathrm{~T} 35 / 2, \times 40 \mathrm{pc}$.

Repository: GSC 137936.

Fig. 20. Tiliaepollenites sp. A.

Location: Karlsefni A-13, 911.36-920.51 m. Sample: cs, P39551, 1.

Optical parameters: D, $134 \times 1000, \mathrm{~N} 43 / 0, \times 40 \mathrm{pc}$.

Repository: GSC 138002. 
Plate 19
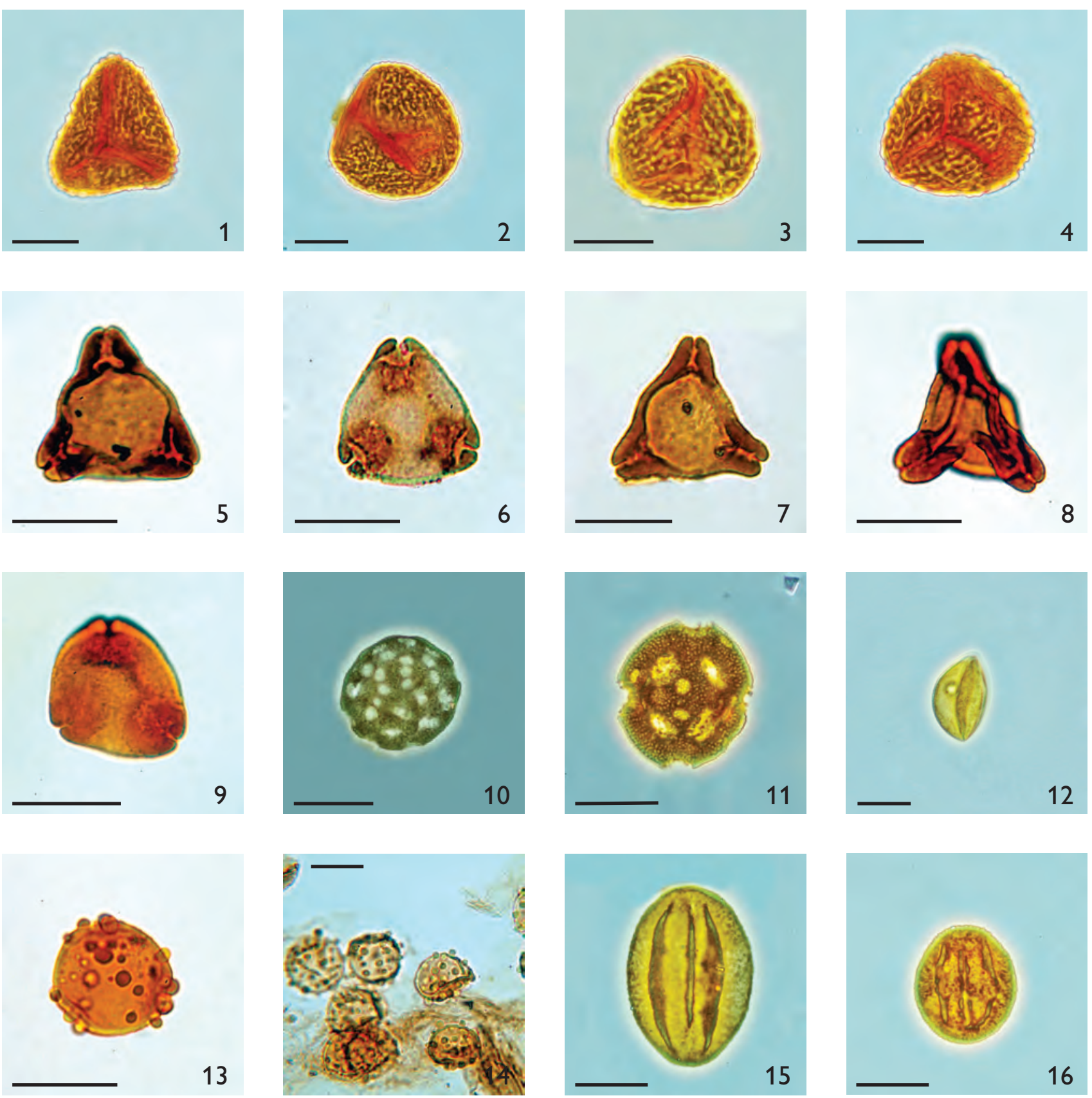

15
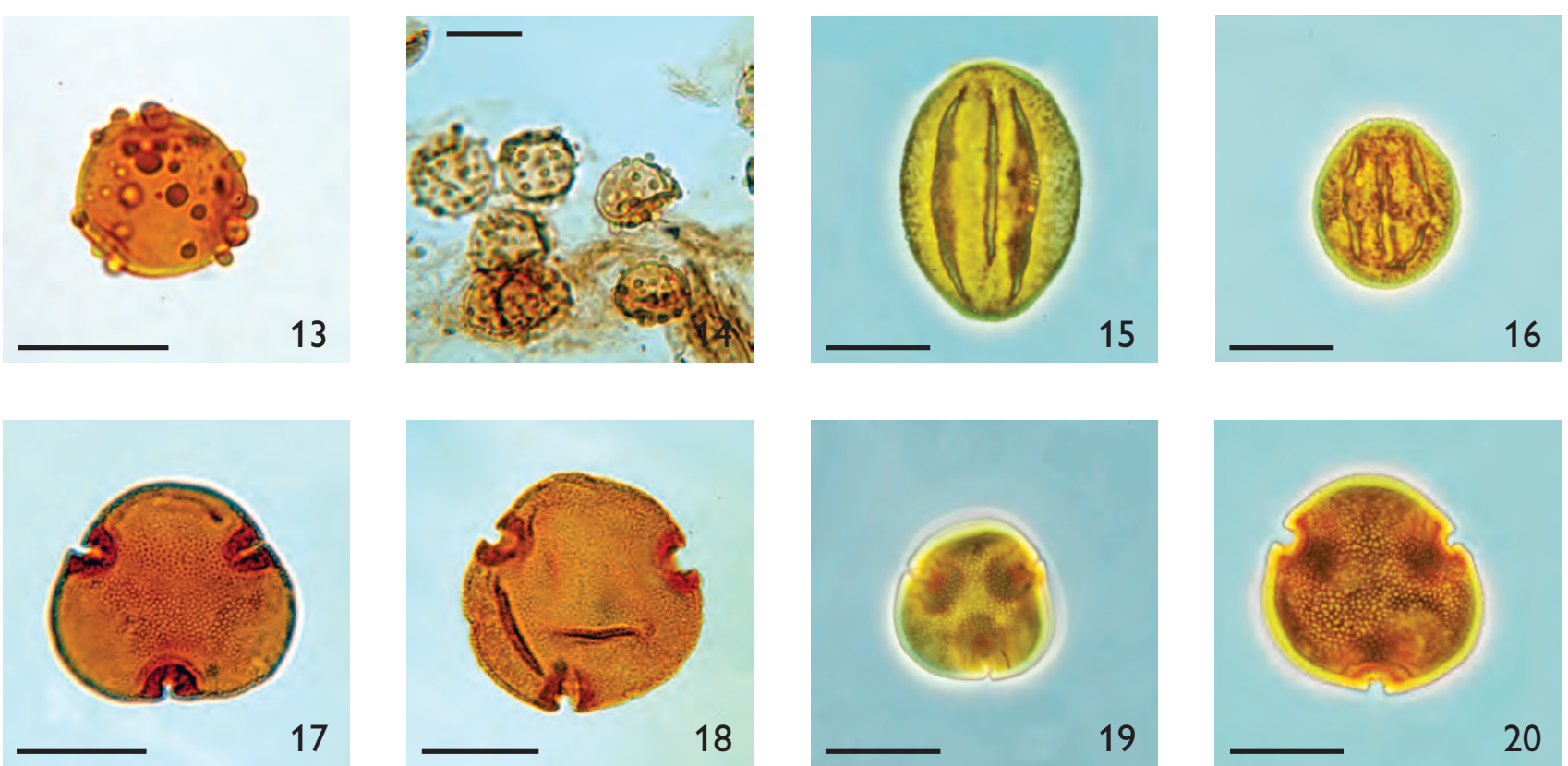
Fig. 1. Osmundacidites wellmannii.

Location: Rut H-11, 905-915 m. Sample: cs, P39324, 1.

Optical parameters: D, $191 \times 968, \mathrm{~T} 39 / 2, \times 40 \mathrm{pc}$.

Repository: GSC 137927.

Fig. 2. Rugubivesiculites sp.

Location: Ogmund E-72, 1965 m. Sample: cs, YD15763, 3.

Optical parameters: A, $35.4 \times 103.2$, N35/2, $\times 60$ bf.

Repository: MGUH 31361.

Fig. 3. Wodehouseia spinata.

Location: Skolp E-07, 1015 m. Sample: cs, YD15576, 3.

Optical parameters: A, $52.0 \times 100.5$, Q53/1, × 60 bf.

Repository: MGUH 31362.

Fig. 4. Zlivisporis sp.

Location: Karlsefni A-13, 1792.25-1801.39 m. Sample: cs, P39582, 1.

Optical parameters: D, $96 \times 851, \mathrm{~J} 27 / 2, \times 40 \mathrm{pc}$.

Repository: GSC 138017.

Fig. 5. Zlivisporis sp.

Location: Rut H-11, 2285-2295 m. Sample: cs, P39370, 1.

Optical parameters: D, $133 \times 1041, \mathrm{~N} 47 / 0, \times 40$ pc.

Repository: GSC 137948.

Fig. 6. Zlivisporis sp.

Location: Karlsefni A-13, 2148.87-2158.01 m. Sample: cs, P39595, 1.

Optical parameters: D, $110 \times 1047, \mathrm{~K} 48 / 3, \times 40 \mathrm{pc}$.

Repository: GSC 138022.

Fig. 7. Zlivisporis sp.

Location: Rut H-11, 1805-1815 m. Sample: cs, P39354, 1.

Optical parameters: D, $120 \times 1031, \mathrm{M} 46 / 1, \times 40$ pc.

Repository: GSC 137940.

Fig. 8. Zlivisporis sp.

Location: Ogmund E-72, 1785 m. Sample: cs, YD15751, 3.

Optical parameters: A, $17.5 \times 111.0$, E17/2, $\times 60$ bf.

Repository: MGUH 31363.

Fig. 9. Zonalapollenites igniculus.

Location: Karlsefni A-13, 859.55-865.64 m. Sample: cs, P39549, 1.

Optical parameters: D, $100 \times 954, \mathrm{~J} 38 / 3-4, \times 40 \mathrm{pc}$.

Repository: GSC 138000.

Fig. 10. Zonalapollenites igniculus.

Location: Rut H-11, 845-855 m. Sample: cs, P39322, 1.

Optical parameters: D, $179 \times 914$, S34/1, × 40 pc.

Repository: GSC 137926.
Fig. 11. Zonalapollenites igniculus.

Location: South Labrador N-79, 720-730 m. Sample: cs, P39744, 1.

Optical parameters: C, $142 \times 1009$, O30/4-P30/2, × 50 bf.

Repository: GSC 138076.

Fig. 12. Fungal element: Callimothallus.

Location: Karlsefni A-13, 2478.05-2487.20 m. Sample: cs, P39607, 1.

Optical parameters: D, $161 \times 1054, \mathrm{Q} 48 / 0, \times 40 \mathrm{pc}$.

Repository: GSC 138035.

Fig. 13. Fungal element: Diporicellaesporites.

Location: Karlsefni A-13, 2505.49-2514.63 m. Sample: cs, P39608, 1.

Optical parameters: D, $127 \times 964, \mathrm{M} 39 / 0, \times 40 \mathrm{pc}$.

Repository: GSC 138036.

Fig. 14. Fungal element: Fractisporonites.

Location: Karlsefni A-13, 1737.38-1746.53 m. Sample: cs, P39580, 1.

Optical parameters: D, $179 \times 889, \mathrm{R} 31 / 4, \times 40 \mathrm{pc}$.

Repository: GSC 138015.

Fig. 15. Fungal element: Fusiformisporites.

Location: Rut H-11, 2285-2295 m. Sample: cs, P39370, 1.

Optical parameters: D, $106 \times 906, \mathrm{~K} 33 / 0, \times 40 \mathrm{pc}$.

Repository: GSC 137946.

Fig. 16. Fungal element: Microthallites.

Location: Karlsefni A-13, 1764.81-1773.96 m. Sample: cs, P39581, 1.

Optical parameters: D, $108 \times 887, \mathrm{~K} 31 / 0, \times 40 \mathrm{pc}$.

Repository: GSC 138016.

Fig. 17. Fungal element: Staphlosporonites.

Location: Karlsefni A-13, 2286.03-2295.17 m. Sample: cs, P39600, 1.

Optical parameters: D, $141 \times 1071, \mathrm{O} 50 / 0, \times 40 \mathrm{pc}$.

Repository: GSC 138031.

Fig. 18. Fungal element: Multicellaesporites.

Location: Karlsefni A-13, 1792.25-1801.39 m. Sample: cs, P39582, 1.

Optical parameters: D, $186 \times 885, \mathrm{~S} 31 / 0, \times 40$ pc.

Repository: GSC 138018.

Fig. 19. Fungal element: Multicellaesporites.

Location: Rut H-11, 3725-3735 m. Sample: cs, P39417, 1.

Optical parameters: D, $175 \times 1043, \mathrm{R} 47 / 4, \times 40 \mathrm{pc}$.

Repository: GSC 137972.

Fig. 20. Fungal element: Pluricellaesporites.

Location: Rut H-11, 2435-2445 m. Sample: cs, P39375, 1.

Optical parameters: D, $160 \times 887$, Q31/1-2, $\times 40$ pc.

Repository: GSC 137953. 
Plate 20
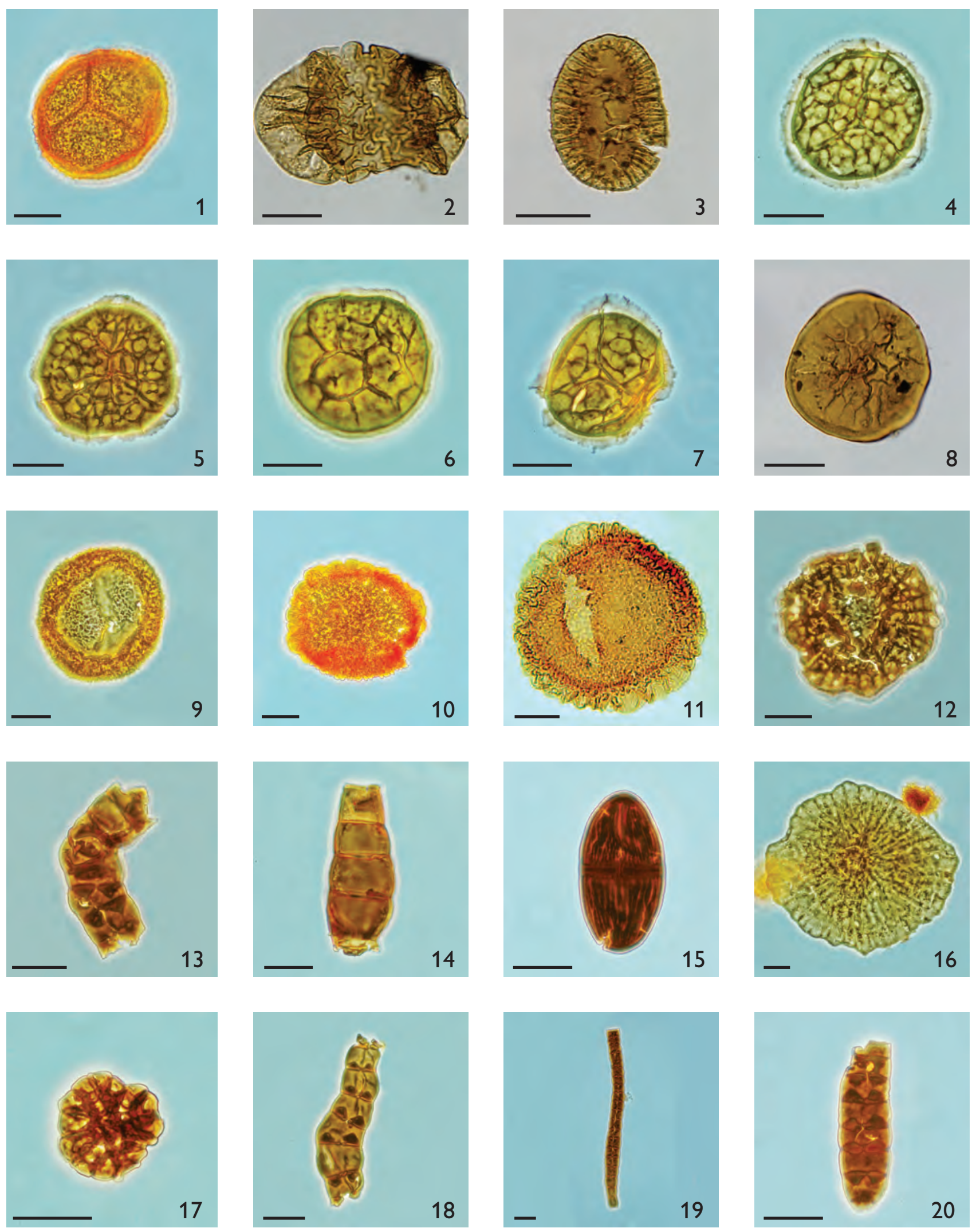
